Historic, Archive Document

Do not assume content reflects current scientific knowledge, policies, or practices. 



\section{GATALOGUE INDEX}

SEED.

Artichoke

Asparagus

Beans

Beet

Bird Seed

Brocoli

Broom Corn

Brussels Sprouts

Cabbage

Carrot

Celery

Cauliflower

Chervil.

Chicory

Clover

Corn

Corn Salad.

Cress......

Cucumber.

Egg Plant.

Endive....

Flower

Grass

Herb

Kale.

Kohl Kavi.

Leek.

Lettuce

Melons, Musk

Melons, Water

Millet.

Mushroom Spawn

Mustard

Nasturtium.

Okra...

Onion

Onion Sets

Pansy

Parsley

Parsnip

Peas....

Pepper.

Potatoes.

Pumpkin.

Radish

Rhubarb

Ruta Baga.

Salsify

Spinach

Squash.
PAGE

9-10

Sugar Cane.

PAGE.

Sunflower.

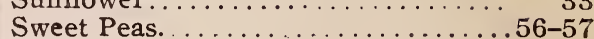

Tobacco.................... 37

Tree Seeds . . . . . . . . . . . . . . . . 46

Tomato...................... . .

Turnip .....................37-38

Vegetable Plants............ 40

Garden Roots and Tubers..... 40

Bee Supplies..................72-73

Plant Department . . . . . . . . . . 74-79

"Planet Jr." Implements . . . . . 66-68

Poultry Supplies ........... . 70-71

Trees and Small Fruits....... 79-80

Collections. Inside Back Cover. MISCELLANEOUS.

Bone Cutters................. 70-71

Books...................... 46

Budding and Grafting Knives........ 69

Bulbs....................... .58-59

Cahoon Seeders. . . . . . . . . . . . . . . . 65

Fertilizers ..................60-61

Garden Tools and Implements. . . . . 65-69

Granger Seeders . . . . . . . . . . . . . . . 65

Grape Dust.................... 65

Hand Cultivators, Diamond ....... 65

Hand Sprayers. . . . . . . . . . . . . 61

Hose...................... 63

Insecticides ................... .64-65

Lawn Mowers.................. . 69

Liquid Sprayers, ...............61-66

Mole Trap......... . . . . . . . 65

Nozzles, .................... . 63

Perfection Sprayer.............. 51

Plant Bed Mats ................ 65

Plant Protecting Cloth .... . . ... 65

Pot Labels. . . . . . . . . . . . . . . . . . $\quad 69$

Potash..................... 61

Prunning, Budding \& Grafting Kniv 69

Pruning Saws.................. 69

Pruning Shears. .............. 69

Raffia.. .................... 69

Roses....................... . . . . 446

Scollay Sprayer . ............. 61

Slug Shot................... 65

Spraying Material ... . . . . . . 60

Spray Pumps ..................62-64

$\begin{array}{llll}\text { Syringes for Spraying } \quad \ldots \ldots & \ldots\end{array}$

Tree Labels. . . . . . . . . . . . . . . . . $\quad 69$

Tree Pruners................... 69

Washes for destroying insects, etc... 64

Weeders...................... 65

Woodason Bellows.............. 61

REFER TO THIS CATALOGUE AS NO. 20.
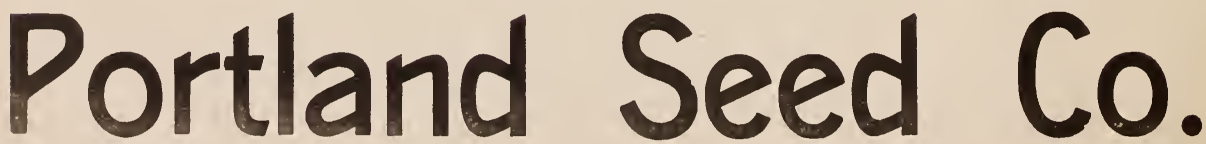

169 and 171 Second Street, PORTLAND, ORE. 


\section{ORDER SHEET. PORTLAND SEED 60.}

PLEASE LEAYE ABOVE SPAEES BLAKK.

NO GOODS SENT C. O. D.
169 and 171 Second Street, PORTLAND, OREGON

GENTLEMEN: Send me the Goods named below, according to the terms as specified itl your 1899 Catalogue.

Name.

\section{Write the address very plainly.}

AMOUNT ENCLOSED BY

Post Offica.

County.

State

$\left.\begin{array}{l}\text { Express or } \\ \text { Freight Office }\end{array}\right\}$ 
Please give us here the names and addresses of some of your neighbors who use seed. 


\section{Portland Seed Company's}

\section{Catalogue and Price List.}

In presenting our general Catalogue for 1899 , we are enabled to say with a good deal of pleasure that the enlargement of our quarters which we made last year was not a mistake, that our friends have entrusted us with a larger amount of orders than we ever had before, and that our business has steadily increased during the year. We now have the best and largest stock of goods tha: we have ever had. We can assure our patrons that not only is the quality of our goods first class, but that we have plenty of stock to fill their orders, and that we will, during the coming season, use as much care in filling our orders promptly and carefully as we have in the past.

Seeds Postage Free. As usual, we offer to send all vegetable and fluwer seeds in quantities of one pound or less by mail postpaid to any postoffice in the United States at the prices named in the Catalogue, except in the case of a few heavy seeds, such as beans, corn and peas, in regard to which special note is made in the catalogue under these different headings. In ordering vegetable or flower seed to be sent by express or freight at your expense, deduct $10 \mathrm{c}$ fer pound from single pound price, except for beans, corn, peas alld onion sets.

IV rite your Name, Postoffice, County and State on the order; inclose with the same sufficient money to pay for the goods, as per price given in this catalogue. Noney can be sent safely either by l'ustoffice Order, Express Money Order, Bank Draft or Registered Letter. l'ostage Stamps will be received for small amounts.

We use every precaution possible in procuring fresh and pure seeds, and shall aim to keep abreast of the market in the selection of new and tried varieties; but it will be impossible for us to hold ourselves responsible for the growth, yield or failure of the crop, in any respect. Neither can we warrant other goods which we handle, but we will use the utmost care in procuring them, also. If our goods are not accepted on these terms, they must be returned at unce. 
We carry a full stock of Garden and Grass Seeds in Bulk, from which we can supply gardeners and large farmers at the lowest market prices.

While the handling of Seeds is our principal business, we also carry stocks of other lines which are often handled by seed merchants, such as Fruit, Shade and Ornamental Trees, Plants, Florists' Supplies, Horticultural and Garden Tools and Fertilizers. We would call special attention to the fact that we have a full line of Potash Salts, from the German Kali Works, Stassfurt, Germany, and also that we have the most complete line of Poultry Supplies in the Northwest. We would request interested parties to write for special Catalogue of Poul= try Supplies.

We have a large assortment of Flowering Bulbs. If interested in this line, write for our Bulb List. which is issued in the fall. Also see under head of Bulbs in latter part of this catalogue.

We would call special attention to our Bee=Keepers' Supplies. We believe that the stock which we offer is not surpassed in quality by anything in the same line in this market. If interested in Bees, send for our Catalogue of Bee=Keepers' Supplies, which is issued in the spring.

If you want anything in the seed line which you do not find quoted in this Catalogue, write us. We can probably supply you with it.

Wishing you all a prosperous year, we are, Yours Truly,

\section{PORTLAND SEED COMPANY.}

\section{SPECIAL PREMIUM OFFER.}

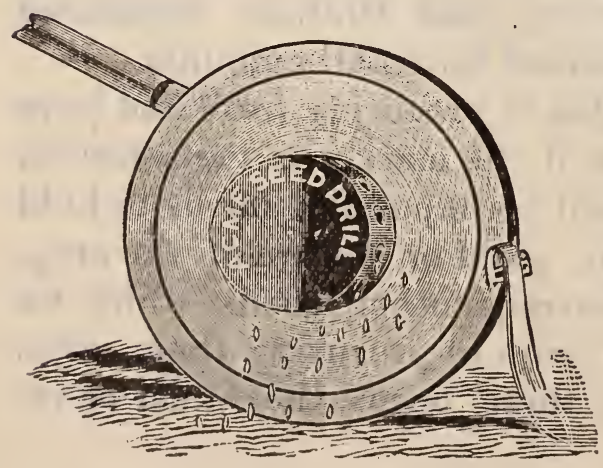

\section{THIS SEED DRILL FREE.}

As our stock of these seed drills arrived late last year, we have concluded to offer them again this season as a premium.

A Garden Seed Drill that will distribute Beet, Caubage. Carrot, Celery, Lettuce, Radish, Turnip, and all su'h seeds. It sows accurately and will do Ten Times the work that can be done by hand. We offer it FREE to any one who purchases $\$ 3.00$ worth of Vegetable and Flower seed by the packet or ounce from us at one time. We deliver it, all charges paid, at your post office. Drill alone $\$ 1.00$, or deliv. ered \$1.25. 


\section{VALUABLE TABLES.}

Table Showing the number of pounds in bushels, and quantity of seed required to sow an acre of ground.

\begin{tabular}{cc|ccc}
$\begin{array}{c}\text { L.bs. per } \\
\text { Bushel. }\end{array}$ & $\begin{array}{c}\text { Lbs. to } \\
\text { Acre }\end{array}$ & $\begin{array}{c}\text { Lbs. per } \\
\text { Bushel. }\end{array}$ & $\begin{array}{l}\text { I.bs. to } \\
\text { Acre. }\end{array}$
\end{tabular}

Alfalfa or Lucerne...... $60 \quad 20$ to 30

Barley-broadcast...... $56 \quad 125$ to 130

Beans, Dwarf or Bush, hills 60

40

80

25

Beans, Tall or Pole, hills. 60

Beet, Garden-drills......

Beet, Field-drills

Broom Corn-drill....... 46

Buckwheat-broadcast ... 50

Cabbage in beds to cover 1 acre after transplanting

Carrots-drills. .

Clover, Red-broadcast...

Clover, White-broadcast.

Clover, Alsike-broadcast.

Clover-Sainfoin ....... 45

Corn, Sweet-hills...... 50

Corn, Field, to cut green

for fodder-drills or

broadcast........... $56 \quad 100$ to 125

Cucumber- hills

\section{2}

30

Flax-when wanted for seed 56

50

Flax-when wanted for fibre 56

Grass, Kentucky Blue, for pasture.

1420 to 30

Grass, Kentucky Blue, for

lawns 14

100

Grass, Orchard 14

20 to 40

Grass, English or Austra-

lian Rye, for meadow...

Grass, English or Austra-

lian Rye, for lawns......

Grass, Italian Rye.......

Grass, Red Top..........

Grass, Timothy..........

Grass, Meadow Fescue or

English Blue Grass.... $20 \quad 20$ to 35

Grass, Mesquite, in the chaff $10 \quad 20$ to 30

Grass, Tall Meadow Oat... $10 \quad 30$ to 50
Grass, Hungarian....... $48 \quad 25$ to 30

Grass, Millet, for pasture.. 5025 to 30

Grass, Millet, for seed.... 50 ن 15

Grass, Mixed Lawn...... 14. 100

A much larger quantity of seed is required to make a close, fine lawn than for other purposes.

Grass mixture........ 36

For mowing $\left\{\begin{array}{l}\text { Clover } \\ \text { Timothy. }\end{array}\right.$

or grazing \{ Red Top.

Hemp-broadcast ...... 44 30 to 40

Melon, Water-hills...... 2 to 3

Melon, Musk-hills...... 2 to $2 \frac{1}{2}$

Oats-broadcast ........ $36 \quad 80$ to 90

Onion, Black Seed-drill.. 4 to 6

Onion, Black Seed, for bottom sets............ 30

Onion Sets-drills........ 250

Parsnip-drills.......... 3 to 5

Peas-drills............ $60 \quad 75$ to 100

Peas-broadcast......... 60100 to 150

Potatoes-hills......... $70 \quad 500$

3 to 4

8 to 10

Radish-drills...........

Rye-broadcast ........ $56 \quad 100$

Sage-drills ........... 8

Spinach-drills .......... 10

Squash, bush varieties-hills

Squash, running varietieshills................ 3

Sugar Cane............ 4 to 5

Tomato-in beds to transplant............... $\quad 2 / 8$ to $1 / 4$

Turnip and Rutabaga-drills $\quad 1 / 2$ to 2

Turnip and Rutabagabroadcast..............

Vetches - broadcast..... $70 \quad 150$

Wheat-broadcast ....... $60 \quad 80$ to 100

Wheat-drills........... $60 \quad 70$ to 80 


\section{FOREIGN NAMES OF VEGETABLES AND HERBS.}

\section{ENGLISH.}

Anise

Artichoke..

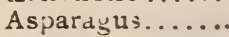

Balin

Basil

Beans

Beet.

Borage

Brocoli

Brıssels Sprouts

Calbbaue

Cabhage, Savoy.

Carawa.

Carr it

Caulifower.

Celery

Celeriac

Chervil

Chirory.

Curianiler

Corn Salad.

Corn.

Cress

Cress. Water

Cucumber.

Dandelion

Dill

Egg Plant.

Endive

F-nnel

Garlic.

Horse Radish

Hyssop..

Kale

Kobl Rabi.

Lavender

Leek

Le tuce.

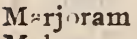

Mrlon.

Melon, IVater

Mushroom

Nasturtium

Okra

Onion.

Parslev

Parsnip

Peas

Prpper

Pumnkin

R.dish

Rlubarb

Rosemary

Rue

Safron

Sage

Salsify

Sorrel

Summer

Sipinach

Squash

Tancy.

Thime

Tomiato

Turnin

Wormuood
GERMAN.

Anis, Gruuer Anis... Anis

Artischoke

Spargel

Citronen-Melisse

....Arichaut

... Asperge

Basilikuin

Bohnen

Rube..

Boretscil

Spargelkohl

Rosenkohl.

Kopfkobi, Kraut

Wirs ng..........

Feld-Kummel
Carotten, Mohren

Blumenkohl.

Sellerie

Knoll-Sellerie

Kerbel

Cichorienwurzel

Coriander

Feldsalat ....

Mais

Garten-Kresse

Brunnenkresse

Gurken

Lowenzahn

] iill

Eierpflanze

Endivien

Fenchel.

Knoblauch

Meer Rettig.

Isop.

Blatterkohi

Knollkohl.

Lavendel

Porree, Lauch

Lattich, Kopisalat.

Majoran.

Melone.

Wasser-Melone

Schwamm

Kapuciner Kresse

Ocher

Zwiebel

Petersilie.

Pastinake

Erbsen.

Pfeffer...

Mrlnnen-Kurbiss

Radies

Rhaharher

Ro:marin

Rauie

Safran.

Salhei.

Haferwurzel

Sanerampfer

Savory.... Bohnenkraut

Spinat

Kurhiss

remeiner Rainfarn

Tlivmian

Jiehesa prel .

W'e sse Rube

Wermutb

Haricols
Melisse Citronelle

Bisilic grand

Betterave

Burrache

Chou Brocoli

Chou de Bruxelles

Chou ponme.

Chou de Milan

Cumin des pres.

Carotte.

Chou-fleur

Celeri.

Celeri-rave

Cerfeuil

Chicoree sauvage

Coriandre

Mache

Mais ........

Cresson alenois

Cresson de fontaine

Concombre

Pissenlit.

A neth

Aubergine

Chicnree Endive

Fenouil

Ail

Raifort sauvage

Hissipe

Chou vert.

Chou-rave.

Lavende

Poireau

Janitue

Marjolaine

Melon

Melon d'eau

Champignon

Capucine

G'mbaud

Oynon

Persil.

Panais

Pois.

Piment.

Potiron

Radis

Rhuharhe

Rnmarin

Rue.

Safran...

Sauge

Salsifis

Oseille

Sarriette annuelle

Fninard

Courge.

Tanaisie

Thym

Pomme d'A mour

Navet...

Absinthe
ITALIAN.

Aniso, Anacio

Articiocca

Sparayio

Melissa.

Fayiuoli

Barbahietola

korrgine

Brocoli

Cavulo di Brusselles

Savolo rappuccio

Cavolo di Millavo

Carvi.

Carota

Carolofiore

Sedano.

Sedanu-rapa

Cerfoglio

Cicr ria selvatica

Cori indurlo

Valeriana

Mais

Agretto

Nasturzio aquatico

Cetriolo

Dente di leone.

Aneto

Petonciano

Indivia.

Finocchio

Aglio

Rafano.

Issopo

. Cavolo verde.

. Cavolo rapa.

Lavanda.

Pirro.

Maggiorana

Popone

Melone daqua

Fungo pratajolo

Nastuızio

Ocra

Cipollo

Prezzemolo

Pastinaca.

Pisello.

Peperone

Zucca

Ravanello

Rabarbaro

Rosmarino

Zafferano.

Salvia

Sassefrica

Acelosa

.Santoreggia

Spinace...

Zucca

Atanasia

Timo

Pomo d'oro

Navone

Assenzio 


\section{General List of Vegetable Seeds.}

Our list of vegetable seeds is as usual made up of standard varieties which have been thoroughly tested and which are known to be first-class. To our list we have added some varieties which, although comparatively new, have still had enough trial to prove that they have inerit. Our assortment, we believe, is large enough to fully supply any ordinary garden; but, should any customer desire some variety of seed which we do not catalogue, we should be pleased to procure it for him.

\section{ARTICHOKE.}

Iarge Green Globe. The variety used as a table vegetable. The edible portion is the flower head. Sow early in drills one foot apart, and when about ten inches high traniplant into rows futur fert apart and two feet in the row. Mulch during dry weather. It prefers ri $h$, deep lo tm and should be well manured every spring. IVill produce only a small crop the first year, but coutiuues in good bearing about five years. Pkt. 5c.; 1 oz. 30c.; 1/4 lb. $90 \mathrm{c}$.

For Artichoke Tubers, see Garden Roots.

\section{ASPARAGUS.}

Sow the seed early in the spring, in drills, about one inch deep. Thin out when the plants are three or four inches high. Keep the soil mellow and free from weeds during the summer. In the fall or succeeding spring, the plants may be set in beds about one foot apart each way, aud the crown six inches below the suriace. The soil should be rich and deeply cultivater to secure a good crop. Do not cut too closely. The roots need the benefit of some foliage during the year. Cover $u$ ith a dressing of manure in the fall, and in the spring work this into the ground. A saving of two years' time may be made by purchasing plants two or three s ears old instead of sowing seed.

Conover's Colossal. Large and of rapid growth. Pkt. 5c; 1 oz. 20 c; $1 / 4$ lb. 20c; 1 lb. 50 c.

Palmetto. About the same size as Colossal, but earlier. Shades on the bright green in color. Pkt. $5 \mathrm{c} ; 1$ oz. $10 \mathrm{c} ; 1 / 41 \mathrm{~b}$. 25c; 1 lb. $75 \mathrm{c}$.

Columbian Mammoth White. It produces pure white shoots, and reyuires no artificial blanching. On this account it brinss in the murket a much higher price than any other sort. It is a strong gruwer, and comes remarkabiy true from seed. Pkt. 5 c; 1 oz. $1 \cup$ c; $1 / 4$ ib. 30 c; 1 lb. 85 c.

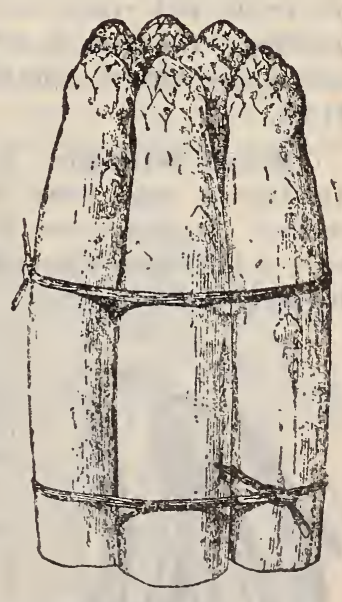

Columbian Mammoth White.

Barr Mammoth. Has very large tender stalks of a very light color. Pkt. $5 \mathrm{c} ; 1 \mathrm{oz} .10 \mathrm{c}$; I/ 1b. 3uc; 1 1b. $\$ 1.00$.

For Asparagus Roots See Garden Roots. 


\section{BEANS.}

\section{DWARF OR BUSH.}

If ordered sent by mail, add 10 cents per lb. for postage.

Six pounds of seed to 100 yards of row.

Plant about the middle of April, if the ground is warm and the season favorable. The best mod-of culture is in rows two feet apart, and the beans three inches apart and two inches deep in rows. Keep well hoed and draw the earth up to thei-stems only when dry, as earth scattered on the leaves $w$ hen wet with rain or dew will cause them to rust and injure the crop.

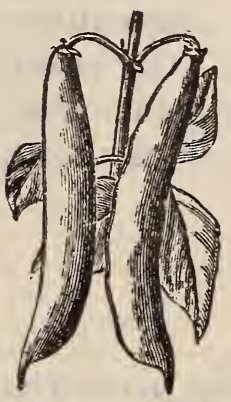

Extra Early Refugee.

GREEN PODDED VARIETIES.

Extra Early Refugee Claimed to be the earliest green-podded variety. Simliar to, hut two weeks earlier than the old Refugee. Pkt. 10c; $1 \mathrm{lb} .15 \mathrm{c} ; 10 \mathrm{lbs} \$ 1.00$.

Early China Red Eye. Tender and early for string beans, also good for shelling. Pkt. 10c; 1 1b. $15 \mathrm{c} ; 10 \mathrm{lbs}$. $\$ 1.00$.

Ear!y Long Yellow Six Wreks. Hardy standard variety; vine vigorous and productive. Pkt. 10c; $1 \mathrm{lb} .15 \mathrm{c} ; 10 \mathrm{lbs} . \$ 1.00$.

Early Mohawk. The hardiest of the hush kinds, and may safely be planted a neek earlier than any other. The pods are pale green, large and broad. The vines continue in bearing a long time and will withstand a light frost. The bean is large and dark purple, mottled. Pkt. 10c; $1 \mathrm{lb}$. $15 \mathrm{c} ; 10 \mathrm{lbs}$. $\$ 1.00$.

Improved Red Valentine. The earliest Valentine Bean. Productive, tender and of excellent flavor. Roundpodded. Pkt. 10c; 1 lb. 15; 10 lbs. $\$ 1.00$.

Refugee or Thousand to One. The best late kind; very productive. The pods are $d a \cdot k$ green reined with purple, tender and crisp, and considered the best variety for pickling. The bean is rather small, oblong, dark purple, and yellow brown, mottled. Pkt. 10c; $1 \mathrm{lb} .15 \mathrm{c} ; 10 \mathrm{lbs}$. $\$ 1.00$.

Broad Windsor. Stalks erect, strong and shrubby. The hean is large, broad and flat. They are best greenshelled. To insure well-filled pods, pinch off the top and ends of the shoo:s when the po's are forming. The best of the English Dwarf Beans. Pkt. 10c; $1 \mathrm{lb} .15 \mathrm{c} ; 10 \mathrm{lbs} .75 \mathrm{c}$.

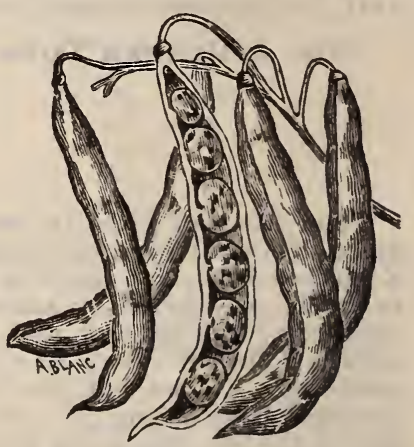

Red Valentine.

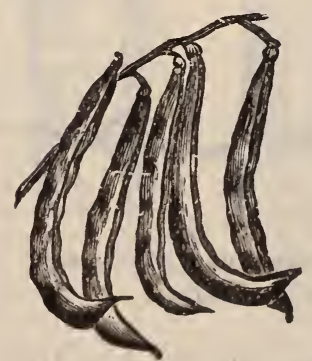

Horticultural.

Dwarf Horticultrral. A strong grower, producing a large crop. The bean is highly prized for use green-shelled, being preferred by some to the Lima; also good dry-shelled. Pkt. 10c; $11 \mathrm{~b}$. $15 \mathrm{c} ; 10$ lbs. $\$ 1.15$.

Royal White Ridney. The bean is large, long, slightly curved, and pure white. It yields a beavy crop, and is one of the best, $t$ i her grten-sl.elled or dry. Pkt. 10c; $1 \mathrm{lb}$. 10c; $10 \mathrm{lbs} .65 \mathrm{c}$.

Henderson's Dwarf Lima. The earliest Lima Bean known. Bean small and of fine flavor. Pkt. $10 \mathrm{c} ; 1 \mathrm{lb}$. $15 \mathrm{c} ; 10 \mathrm{lbs} . \$ 1.15 \mathrm{c}$.

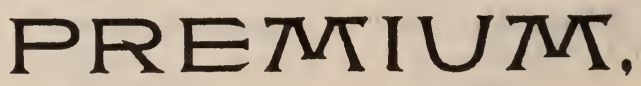




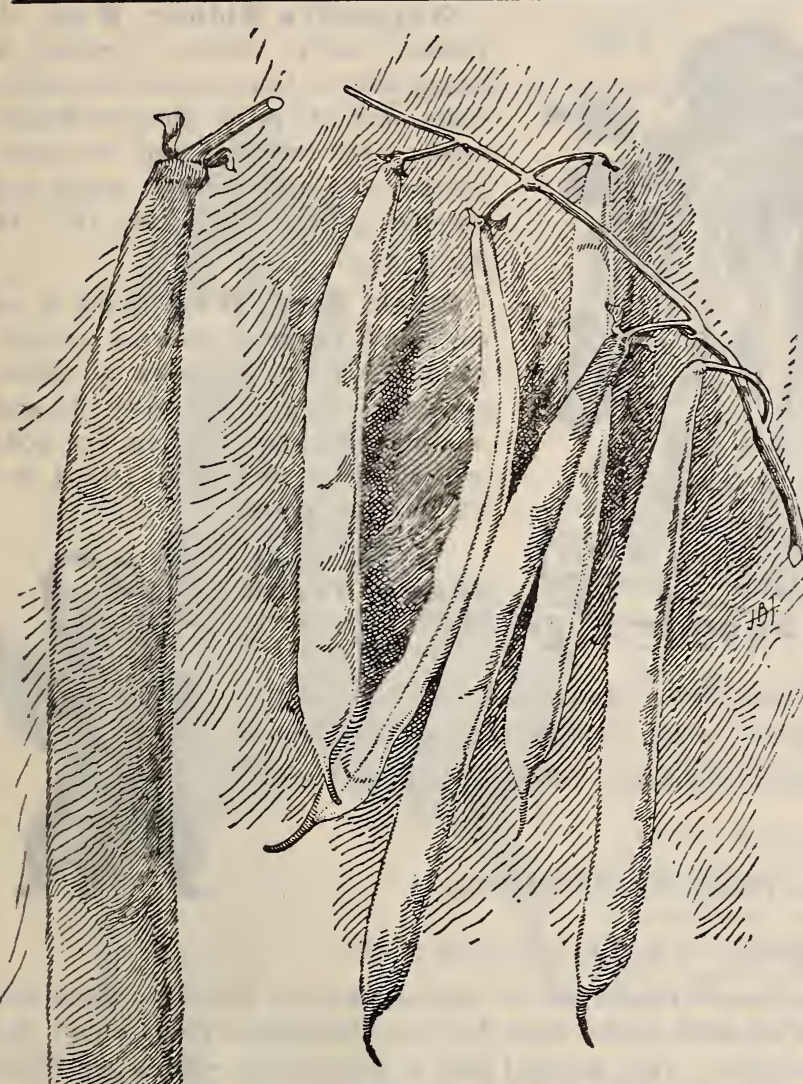

Burpee's Bush Lima. A Bush form of the large $\mathrm{Al} t$ pole Lima. Pkt. 10c; 1 lb. 15c; 10 1bs. $\$ 1.15$.

Improved Tree Bean. The most prolific field variety. Grows twenty inches high and branches out like a tree. Pkt. 10c; 1 1b. 10c; 10 lbs. 60c.

WAX VARIETIES.

Davis Wax. A hardy, rustless and immensely-pro ductive bush variety. The pods are long, nearly straight, white and handsome, and are carried well up off from the ground. Cooked when young, they are tender, juicv and of fine flavor. It is one of the best for market garreners, because of its hardiness, prorluctiveness, handsome appearance, its good shipping and selling qualities, aud the small proportion of waste and second-quality pods. Canners say "it is just what we want, a long, straight, clesi white por, which does not discolor in canning." The large, white, handsome kidney-shaped dry beans are attractive. Pkt. 10c; I lb. 15 c; 10 lbs. $\$ 1.25$

\section{Davis Wax.}

Rust Proof, or Detroit Wax. It is not likely to rust even when exposed to very wet weather. Pod flat, good length and very broad. It is valuable for shipping, as it keeps fresh and crisp a long time. It is extra early; quality in the pod all that can be desired, and also excellent green shelled. Pkt. 10c; 1 lb. 15c; 10 lbs. $\$ 1.00$.

\section{Golden Wax Dwarf.}

The standard wax bean. The pods are large and long and en. tirely stringless. As a snap bean it excels all other sorts in tenderness and richness of flavor, and has the further merit of being one of the best shell beans grown for winter use. Pkt. 10c; 1 lb. $15 \mathrm{c} ; 10$ lbs. $\$ 1.00$.

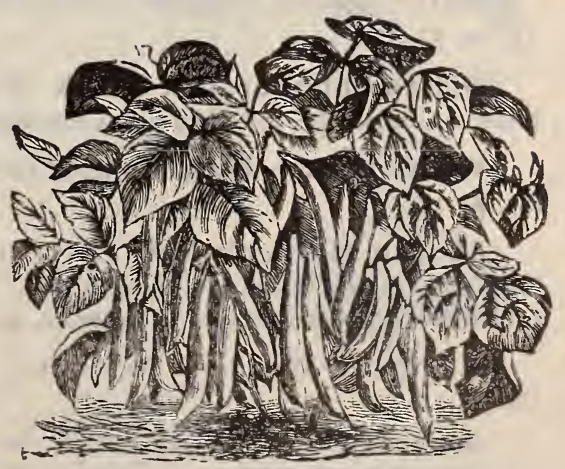

Golden Wax Dwarf.

German White Wax. A variety similar in every respect to the Black Wax, except in color, which is pure white. Pkt. 10c; 1 1b. $15 \mathrm{c} ; 10$ lbs. $\$ 1.00$. 


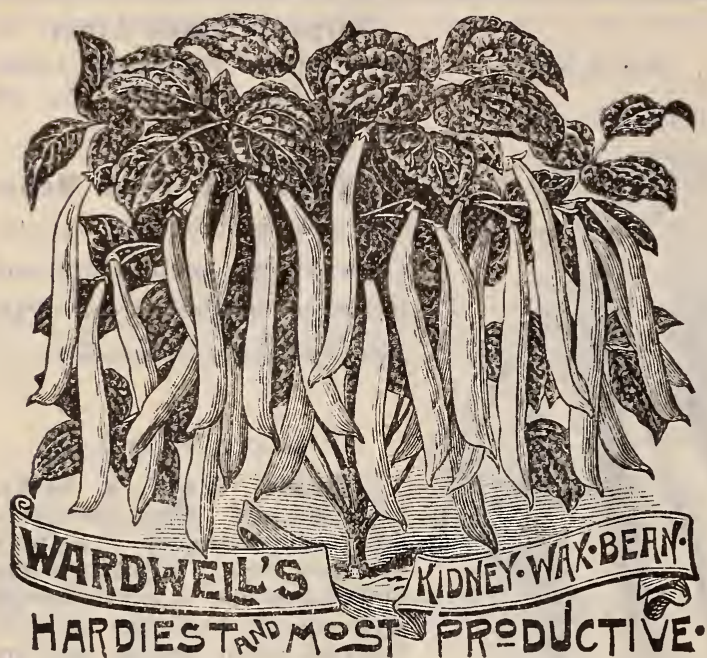

Wardwell's Kidney Wax. A robust, harily variety, yielding a heavy crop of large, unusually handsome, wax like poils. They are fleshy, tender and excellent, and are realy for the table earli-r than many wax varieties. Pkt. 10c; 1 lb. $15 \mathrm{c} ; 10$ 1bs. $\$ 1.00$.

Black Eyed Wax. This is an early and rigorous growing variety, yielding a great profusion of tender pods, the vine growing about one and one-balf feet high, holding the pods

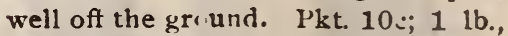
$15 \mathrm{c} ; 10 \mathrm{lbs}$. $\$ 1.00$.

Extra Chal-
1enge B1 a ck
Wax. Fxtremely
early, and may be

considered the most desirable for first crop. The plants are vigorous and very productive; pods resemble those of the Prolific German Wax, but a little flatter. Ripe beans jet black, medium size. Pkt. 10c; 1 1b. 15c; 10 $\$ 1.00$.

\section{POLE OR RUNNING.}

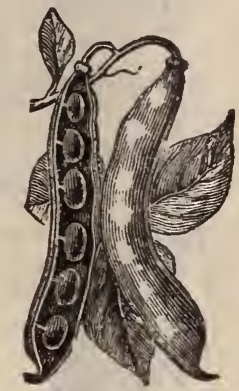

Three pounds of seed to 100 yards of row.

All under this head require poles and should not be planted until the ground is warm and all danger of frost is past, as they are more tender than the dwarf varieties. Plant about the midule of May, if the season is suitable. They succeed best in sandy loam, with a shovelful of rich, light and well-rotted compost to each hill, well incorporated.

Early Dutch Knife Case. This is one of the earliest and most prolific varietie; it has long, flat pods, with white seeds, and is gooa green or dry. Pod green. Pkt. 10c; 1 b. $15 \mathrm{c} ; 10$ lbs. $\$ 1.15$.

Large White Lima. The standard pole Lima Bean. Pkt. 10c; 1 1b., 15c; 10 lbs. \$1.25.

Early Golden Cluster. Extra early, productive, of good quality. Pkt. 10c; 1 lb. 15c; 10 lbs. $\$ 1.25$.

Indian Chief, or Tall Black Wax. Remarkable for its fine, tender and succulent pods, which are produced in great abundance. Pkt. $10 \mathrm{c} ; 1 \mathrm{lb} .15 \mathrm{c} ; 10 \mathrm{lbs} . \$ 1.15$.

White Crease Back. A good early green-podded pole bean. Pkt. 10c; 1 lb. 15c; 10 1bs. $\$ 1.15$.

Iondon Horticultural. Very desirable for the family garden. Vines vigorous, bearing light green pods. streaked with red. The bean is large, ovdl, creani colore t, bedutifully splashed with red, and has no superior, green shelled or dry. Pkt. $10: ; 1$ lb. 15 c; 10 lbs. $\$ 1.15$.

Kentucky Wonder. Pods green, very long. Productive. Pkt. 10c; 1 lb. 15c; 10 lbs. $\$ 1.10$.

Asparagus. Pods long and slender, sometimes growing to one foot in :ength. Green in color. A good yie!der and extensively used for canuing. Pkt. 10c; 1 lb. 20c.

Scarlet Runner. The most productive, perliaps, of all the Kirney Beans. It is cultivated for the beauty of its flowers, as well as for the economical uses to which its pods and seeds can be applied. Pkt. 10c; $1 \mathrm{lb} .20 \mathrm{c}$. 


\section{BEET.}

Five ounces of seed to 100 yards of row.

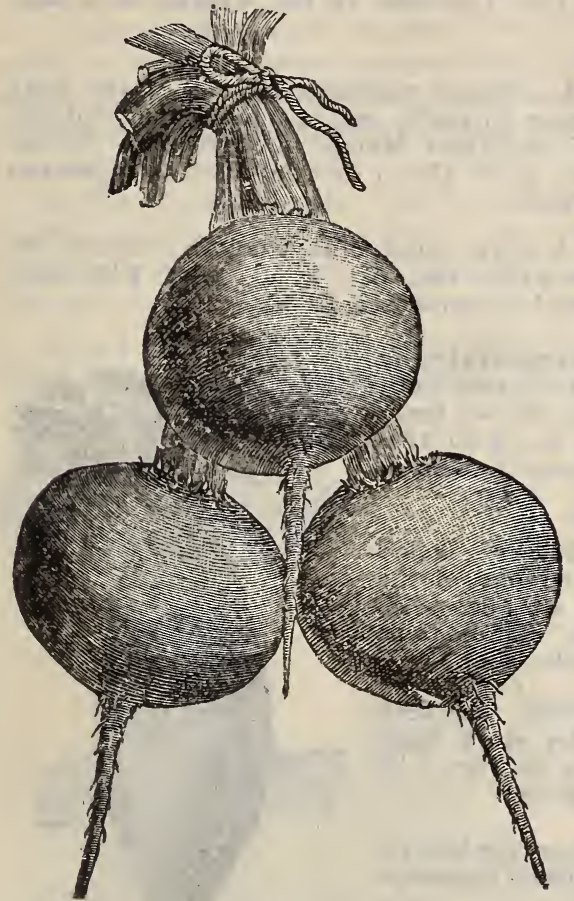

Eclipse Beet.

The soil best suited for beet culture is that which is rather light, provided it is well enriched. Sow in drills one foot apart and one inch deep, as early as the ground can be worked in the spring, for an early supply. When the plants are large enough, thin out to stand six or fight inches apart in the rows. Continue sowing for a succession as late as the middle of July for the early varieties. Keep free from weeds. The sugar and Mangel-Wurzel varieties are grown for feeding stock, and should be sown from $A_{1}$ ril to June in drills two feet apart, and afterwards thinned out to stand one foot apart in the rows. Keep them well cultivated.

Eclipse. This variety has proven itself one of the best early turnip beets yet introrluced on account of its wonderfully rapid growth, small tops, and extra fine quality. Pkt. $5 \mathrm{c} ; 1 \mathrm{oz} 10 \mathrm{c}$; $1 / 41 b .20 c ; 11 b .50 c$.

Early Bassano. This variety produces a large top and leaf stalks that are excillent cooked with the young roots. They should be ust d as soon as large enough, as they become coarse and tasteless with age. Flesh light red, zoned with white. Pkt. 5c;1 oz. 10c; 1/4 1b. 20c; 1 1b. $50 \mathrm{c}$.

Bastian. A very early, light colored turnip beet. Pkt. $5 \mathrm{c} ; 1 \mathrm{oz} .8 \mathrm{c}$; \%/4 1b. 15c; 1 1b. $45 \mathrm{c}$.

Long Dark Blood. Excellent for winter; sweet and tender, blood red, long and smooth. Pkt. 5c; 1 oz. 10c; 1/4 lb. 20c; 1 b. 50c.

Half Long Blood. One of the rery best for winter use; does not become wood», and keeps equally as well as the Long Dark Bluod. The root is as smooth and handsome and the flesh as brilliant in color and good in quality as the best Blood Turnip varieties. Pkt. $5 \mathrm{c} ; 1 \mathrm{oz}$. 10c; $1 / 4$ 1h. 20c; 1 lb. 50 c.

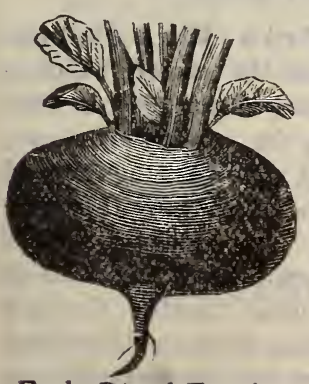

Early Blood Turnip.

Early Blood Turnip. The learing turnipshaper variety: of medium size, rapirl growth, not liable to become wcodv; keeps well. Flesh, bright red, tender and sweet. Pkt. $5 \mathrm{c} ; 1 \mathrm{oz}$. 10c; $1 / 41$ b. 20c; 1 lb. 50c.

Early Egyptian. Eariy, red, smooth skin, small trp, grows much ahove ground; good for spring and early summer use. Pkt. 5c; 1 nz. 1 nc; $1 / 4$ lb. 20c; 1 lb. 50 c.

Edmand's Blood Turnip. A market gardeners' strain of yreat regularitv in shape: deep blood skin and rery dark flesh of best quality. Pkt. 5c; 1 oz. 10 c; $1 / 4$ 1b. 20 c: 1 lb. 50 c.

Swiss Chard, or Sea Kale Beet. Cul-

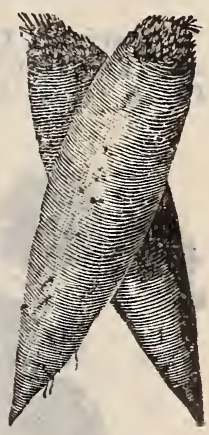

Half Long Blood

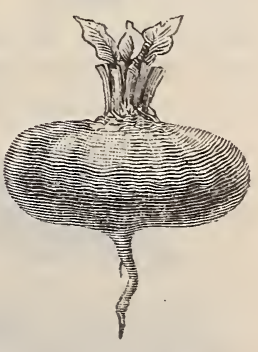

Early Egyptian.

tivated exclusively for its leaves and leaf stalk. Which are prepared and served similar to asparagus, and are tender and delicious. If cut frequentiy, the young leaves re-appear and make excellent greens. Pkt. $5 \mathrm{c} ; 1$ oz. $10 \mathrm{c}$; 1/4 1b. 20c; 1 ib. $50 \mathrm{c}$. 


\section{MANGEL-WURZEL AND SUGAR BEETS.}

Mammoth Inng Red. A very large variety, growing much above ground. One of the heavl.st cro sping varieties. Pkt. $5 \mathrm{c} ; 1 / 4 \mathrm{lb}$. $15 \mathrm{c} ; 1 \mathrm{lb} .40 \mathrm{c} ; 10 \mathrm{lbs}$., express to be paid by purchaser, $\$ 2.50$.

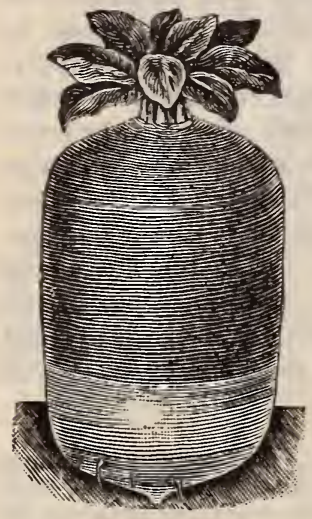

Golden Tankard.

Golden Tankard. This is undoubtedly one of the most profitable varieties to grow for stock, as it is an enormous cropper, and said to be the most nutritious Mangel in culivation. Color, bright yellow. Pkt. 5c; $1 / 4 \mathrm{lb} .15 \mathrm{c} ; 1 \mathrm{lb} .40 \mathrm{c} ; 10 \mathrm{lbs}$, express to be paid by purchaser, $\$ 2.50$.

Yellow Globe. A large, round, orange-colored variety, excellent quility, keeps well. Pkt. 5c; 1/4 1b. 15c; $1 \mathrm{lb} .40 \mathrm{c}$; $10 \mathrm{lbs}$, express to be paid by purchaser, $\$ 2.50$.

\section{Golden Giant Intermediate, or} Leviathan. A variety of great merit for stock feeding. Skin, yellow ; flesh, white and sweet. Pkt. 5c; 1/4 1b. 15c: $1 \mathrm{lb} .40 \mathrm{c} ; 10 \mathrm{lbs}$., express to be paid by purchaser, $\$ 2.50$.

Iane's Imperial Sugar. This is an excellent variety and one of the best for stock feeding. Pkt. 5c; $1 / 41 \mathrm{~b}$. 15c: 1 lb. $40 \mathrm{c} ; 5 \mathrm{lbs}$., express to be paid by purchaser, $\$ 1.50$.

French White Sugar. Large and excellent. The flesh is of a fine grain, tender and sweet. Superior for stock feeding, and for the table when young. Pkt. $5 \mathrm{c} ; 1 / 41 \mathrm{~b} .15 \mathrm{c} ; 1 \mathrm{lb}$. $35 \mathrm{c} ; 10 \mathrm{lbs}$., express to be paid by purchaser, $\$ 2.50$.

German Imperial White Sugar. It gives the best results raised in sandy soil, free from alkali. Good for stock. Pkt. 5c; 1 oz. $10 \mathrm{c} ; 1 / 4$ 1b. 20c; 1 lb. 50c.

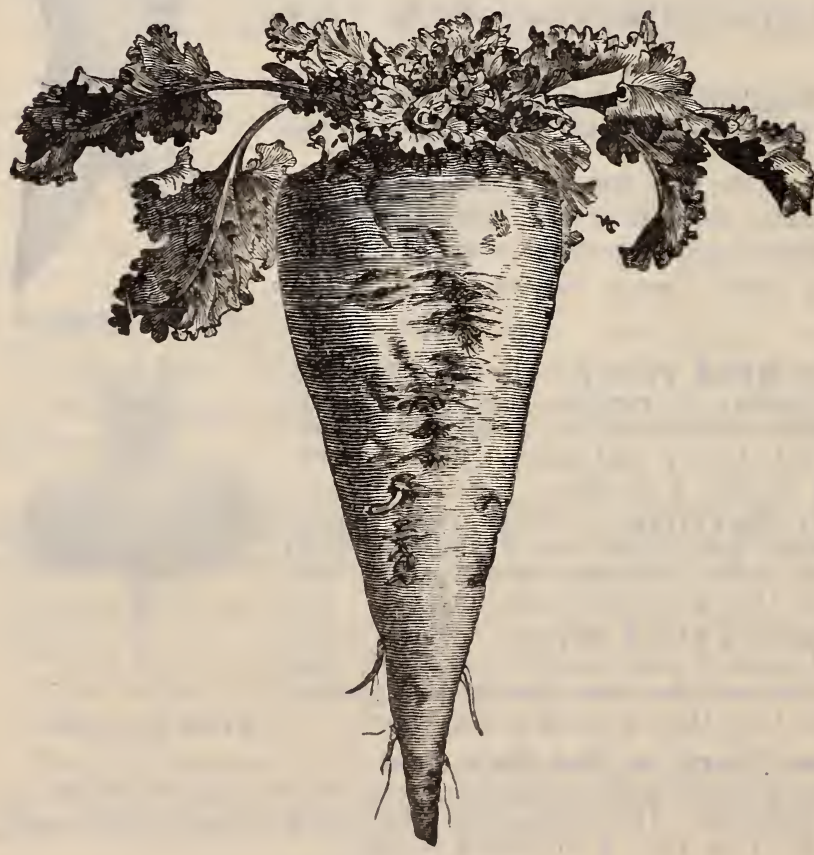

Klein Wanzleben.

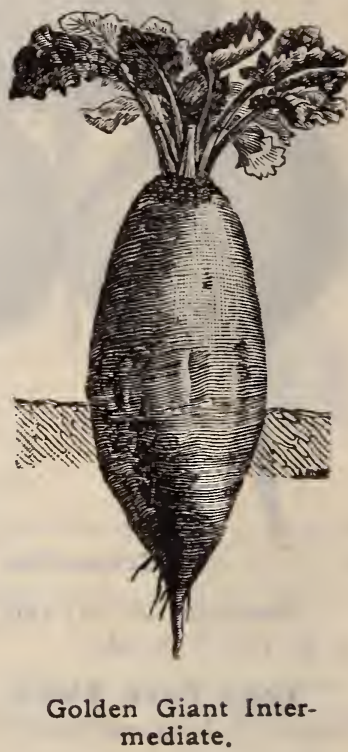

Vilmorin's Improved Sugar. Very rich in sugar and does well on new lands. Pkt. 5c; 1 oz. 10c; /// 1b. 20c; 1 lb. 50c.

K1ein W anzleben. This is the variety which is considered the best in Germany for producing sugar, and it is now taking the lead in this country for this purpose. Our stock of seed is imported direct from one of the most careful German growers, and should be used where the best results are desired. Pkt. 5c; 1 oz. 10c; 1/4 1b. 20c; $1 \mathrm{lb} .50 \mathrm{c} ; 10 \mathrm{lbs}$, purchaser to pay express, $\$ 3.00$. 


\section{BROCOLI.}

One ounce of seed to 100 yards of row.

Produces heads in the autumn like cauliflower, but is more hardy. Sow about the middle of May; transplant in well-enriched soil and manage the same as winter cabbage. For an early crop, the seed should be sown in a hot-bed, and cultivated the same as early cauliflower. It succeeds best in a moist soil and cool climate and can be had in perfection from November till March.

Early Purple Cape. This is the best for the North, producing compact heads of a brownish purple and of good flavor. Pkt. 5c; 1 oz. 35c; $1 / 41$ b. $\$ 1.15$.

White Cape. Similar to the Purple Cape, except in color. Pkt. $5 \mathrm{c} ; 1$ oz. 35c; $1 / 41 \mathrm{~b} . \$ 1.15$.

Large White French. Not as early as the above. Heads large, and of a creamy white; close and most certain to head. Pkt. $5 \mathrm{c} ; 1$ oz. $30 \mathrm{c} ; 1 / 71 \mathrm{~b} . \$ 1.15$.

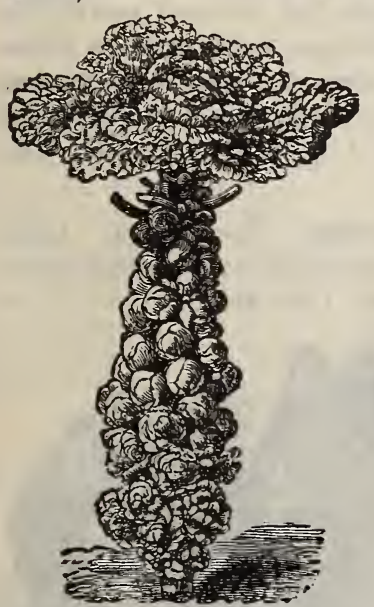

\section{BRUSSELS SPROUTS.}

One ounce of seed to 100 yards of row.

Produces from the stem small heads, resembling miniature cabbages. The sprouts are used as greens, and become very tender when touched by the frost. Sow in May and manage the same as winter cabbage.

Dwarf Improved. Producing compact sprouts of extra quality. Pkt. 5c; 1 oz. 10c; 1/4 1b. 35c; 1 lb. \$1.25.

Brussels Sprouts.

\section{CHERVIL.}

Sow at any time in the spring in shallow drills, one foot apart, in well-prepared ground.

Curled. The leaves are used for flavoring soups and stews, and for garnishing, same as parsley. Pkt. $5 \mathrm{c} ; 1$ oz. $15 \mathrm{c} ; 1 / 4 \mathrm{lb}, 30 \mathrm{c}$.

\section{CHICORY.}

Sow in April in drills half an inch deep, in good, mellow soil, and cultivate like carrots. Cut up and dry the roots, and roast and grind like coffee. Mix abour one-fourth of ground Chicory with the coffee before cooking. It takes the deleterous effect from the coffee and improves its flavor. The plants can be blanched and used as a salad.

Large Rooted. The best known substitute for coffee. Pkt. 5c; 1 oz. 10c; 1/4 1b. 20c; 1 lb. 75c.

\section{CORN SALAD, OR FETTICUS.}

Sow during August or early in September, in drills a quarter of an inch deep and six inches apart. If the weather is dry when the seed is sown, tread it in lightly to insure germination. Keep down weeds with hoe. Just before the winter, cover thinly with straw or leaves.

Large Seeded. Pkt. $5 \mathrm{c} ; 1$ oz. $10 \mathrm{c} ; 1 / 41 \mathrm{~b} .20 \mathrm{c} ; 1 \mathrm{lb}, 60 \mathrm{c}$.

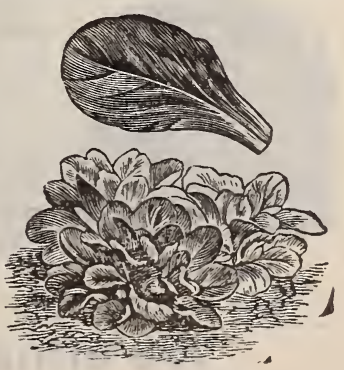

Corn Salad. 


\section{CABBAGE.}

Cabbage will thrive in almost any soil: but to bring it to the greatest perfertion, the soil should be deep, rich and nusist. The ordinary method for early use is to sow it in hotbed or cold frame in winter, or very errly in the spring. Some garleners sow in the early fall, and cover the plants with a cold frame until early spring. For field culture, they may be so $\mathrm{wn}$ in beds and transplanted. Plant the early varieties one and one-lialf to three feet apart, and the large late kinds three to four feet apart each way. In transplanting. set the plants up to the first leaf, no mitter how long the stem may be. Keep the ground well stirred and free from weeds, and if large crops are wanted, manure very heavily. There is hardlv a possibility of using too much manure.

We take special care to have our stock of Cabbage Seed the very best, and we feel safe in recommending it as being of the very finest strain. We are sure that market gardeners who use our Cabhage Seed once will call for it ayain.

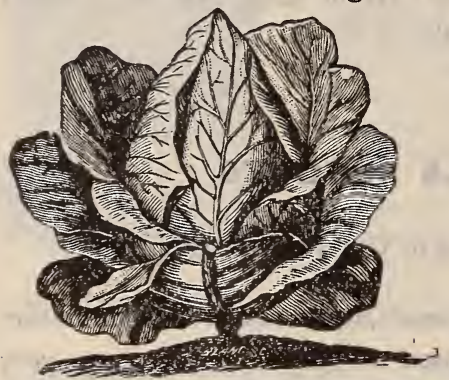

Extra Selected Ear'y Jersey Wakefield. Special strain of fine seed front the farms of one of the o'dest and most reliable Cabbage Seed growers in the United Siates. Just the thing for market gardenters. The heads are of excellent quality, and of large size for so early a variety. $\mathrm{Pkt}$. $5 \mathrm{c} ; 1 \mathrm{oz} .15 \mathrm{c} ; 2 / 4 \mathrm{lb} .50 \mathrm{c} ; 1 \mathrm{lb}$. $\$ 1.75$.

Early Jersey Wakefield. Good Stock. A different strain of the Jersey Wakefield as described above. Pkt. 5c; 1 oz. 10c; $1 / 4$ 1b. 35c; 1 1b. $\$ 1.25$.

\section{Extra Selected Early Jersey Wakefield.}

Extra Early Express. Produces fair-sized heads in eiglity to eighty five days from sowing of seed. Very valu$\mathrm{ab}$ e to the market gardener. Pkt. 5c; 1 oz. 15 c; $1 / 4$ lb. 50 c; 1 lb. $\$ 1.75$.

Early York. Small, but very early. Pkt. 5c; 1 oz. 15c; 1/4 1b. 40c; 1 lb $\$ 1.25$.

Winnigstadt. A fine, tender cabbage, excelient for summer; will d' wel for fall or winter, if sown late. The best variety to sow in the late summer for growing plants to winter over in the cold frame. Pkt. 5c; $1 \mathrm{oz} .15 \mathrm{c} ; 1 / 4 \mathrm{lb} 50 \mathrm{c}$; $1 \mathrm{lb}, \$ 1.50$.

Early Flat Dutch. A medium early kind. Hears large, round, slinhtlv flattened. It grows low on the stem and is a sure hearler; firm, fine-grained, tender and excellent. Keeps almost as will as

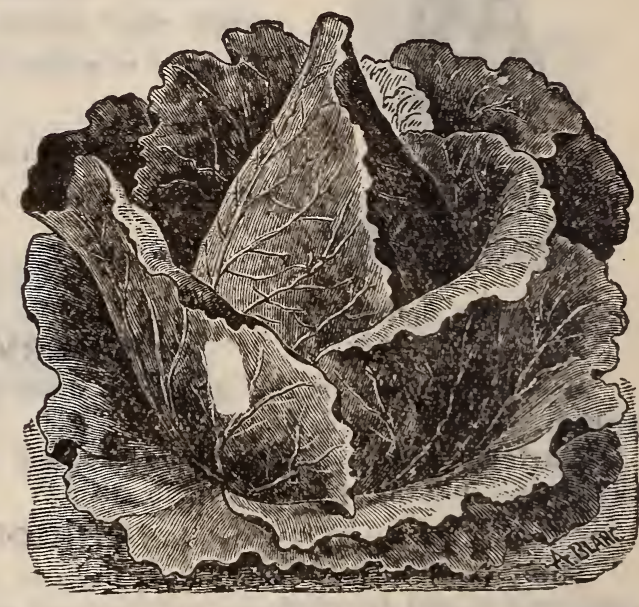

Winnigstadt. the late kinds. Pkt. 5c; 1 oz. $15 \mathrm{c} ; 1 / 4$ 1b. $45 \mathrm{c} ; 11 \mathrm{~b} . . \$ 1.50$.

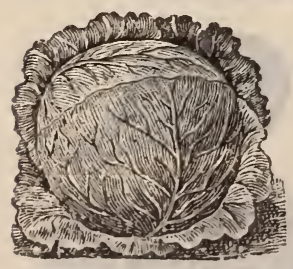

Henderson's

Early Summer.

German Filderkraut, Heads rather larger and more pointed than the Winnigstadt, whi, $h$ it resrmbles. It is of excellent quality, and highly esteemed for making kraut. Pkt. 5c; 1 oz. 15c; 1/4 1b., 5(ic; 1 lb. $\$ 1.50$.

Henderson's Early Summer. About ten days later than the Jersev Wakefirld. The heal is round and the large-t of the early kinds. Thev can be set close in the row, as the cuter leaves are small. It rema'ns long without bursting, is firm, and of the best quality. Pkt. 5c; 1 oz. $15 \mathrm{c} ; 1 / 4 \mathrm{lb}, 50 \mathrm{c} ; 1$ lb. $\$ .1 .50$. 
Fottler's Improved Brunswick. Th.s is ui h ut exception the best Early Drum. head var.ty in the market and is used w the market folleners to succerd the earliest varieties: al o for a late cron. Sure to head, often weighing from twenty to thirty pounds. The quality is excellent. l'kt. 5c; $1 \mathrm{oz} .15 \mathrm{c} ; 1 / 4 \mathrm{ll}$. $50 \mathrm{c} ; 1 \mathrm{lb} . \$ 1.50$.

Siccession or All Seasons. Medium eally: heads large. round, slightly flattened; grous low unt ti e stem and rest mber the farly Summer, exce pi that the hearls are nsually larger. It is aloo a goud keeler, and can be used as a fall aud winter variety. Pkt. 5c; 1 oz. $15 \mathrm{c} ; 1 / 4$ lb. $50 . ; 1$ lb. $\$ 1.50$.

Henderson's Autumn $K$ ing. Enormous sol.d hearls, dark yreen in color: lew ouler liaves, which allows an unu-ually large crop to be gro ill per acre. Pkt 50 ; 1 oz. 20 ; $1 / 4$ lb. 6uc; 1 1b. $\$ 2.00$.

Premium Flat Dulch. Siecial Strain. The standard late variety. Produ es larke, round hrads Flattened on top. $\mathrm{H}$ eads is ure to form. heeps nell ard is of excellent flavor, tender and swett. Grows low on the stem. Our seed is the very he-t strain. Pkt 5c; liz. 15c; 1/4 lb. 50c; 1 lb. $\$ 150$.

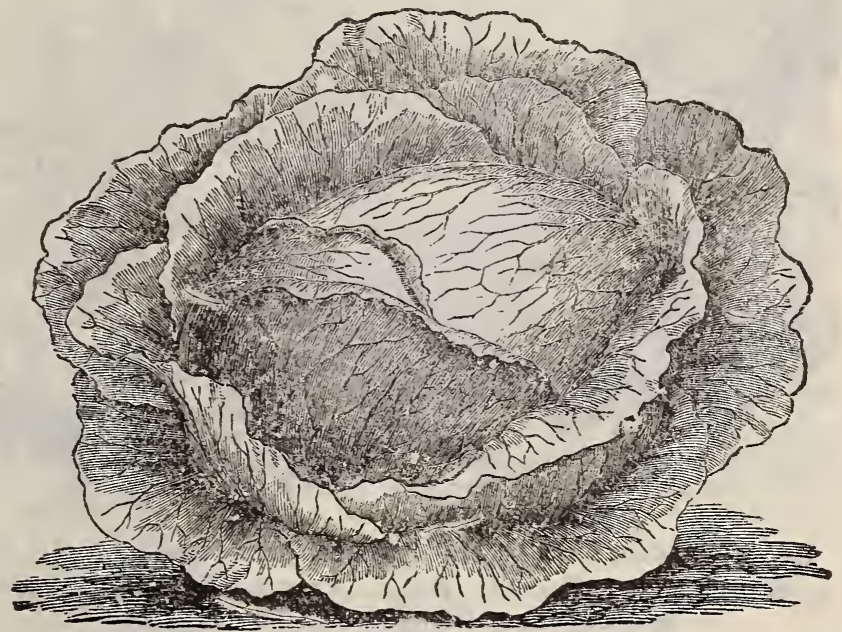

Premium Flat Dutch.

Stone Mason M s r b ehead. A large Drumhead variety: sure to head, fine grained, tender, remarkably sneet and del cions. It is very h*rdy, enciuring strere frost and easily kept all winter. Pkt. 5c; 1 oz. $15 \mathrm{c} ; 1 / 4$ lb. 50c; 1 ib. $\$ 1.50$

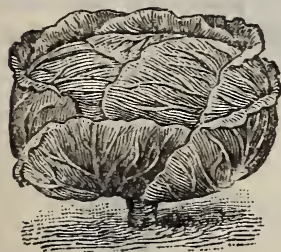

Premium Drumhead.

Premium Drumbead. Extra Stnck. A large and very popular varie y for winter. Pkt. 5c; $1 \mathrm{cz}, 15 \mathrm{c}$; $1 / 4 \mathrm{lb} .50 \mathrm{c} ; 1 \mathrm{lb}$. $\$ 1.50$.

\section{5}

Danish Ball Head. Very roind. solid, winter sort from Denulalk. Pkt. 5c; 1 Oz. 25c; 1/4 1b. 75c; $1 \mathrm{lb}$. \$2.75.

Red Dutch. Used for pickling. Pkt. 5c; $1 \mathrm{oz} .20 \mathrm{c} ; 1 / 4 \mathrm{lb}$ $60 \mathrm{c} ; 1$ lb. $\$ 1.75$.

Mamm th Rock ReA. True. This is the rest, largest and most iel alle hearing sed ralliage. The head is large, iched, solid, and of a det $\mathrm{p}$ red culor. Pkt. $5 \mathrm{c} ; 1$ (z. 20c; $1 / 411.65 \mathrm{c} ; 11 \mathrm{~b} . \$ 2.00$.

Vandergaw. A sure heading, quick growilg Flat liu.ch surt. Pkt. $5 \mathrm{c} ; 1$ oz. $20 \mathrm{c} ; 1 / 41 \mathrm{~b} .65 \mathrm{c}$ : $1 \mathrm{lb}$. $\$ 2.00$.

Neted Savoy. This is the finest of the Savny Cabliges, and a general favorite whesever it is known; of excillent flavir, surinssing that of any olher late cabhage. Stands ireezing best of all winter cabuages. Pkt. 5c: $1 \mathrm{oz} .20 \mathrm{c}$ : $1 / 4 \mathrm{lb}$. 50c; $1 \mathrm{lb} \$ 1.50$.

Drumbead Savcy. Forms a lerge and compact head. very tender and excellent in winter: delicious, rich flavor. l'kt. 5c; 1 oz. $15 \mathrm{c} ; 1 / 4$ lb. $50 \mathrm{c} ; 1 \mathrm{lb} . \$ 1.50$.

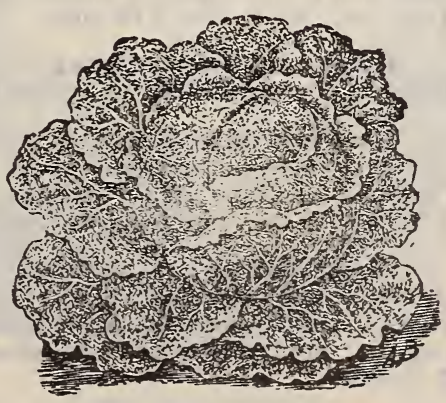

Drumhead Savoy.

For Cabbage Plants, see list of Vegetable Plants. 


\section{CARROT.}

Three to four pounds of seed to the acre.

This vegetable succeeds best in sandy loam, well enriched. For early crop sow in the spring as sonn as the ground is in good condition. For late crops, sow until the middle of June. Sow in drills one inch deep and eighteen inches apart, thinning out to three or four inches.

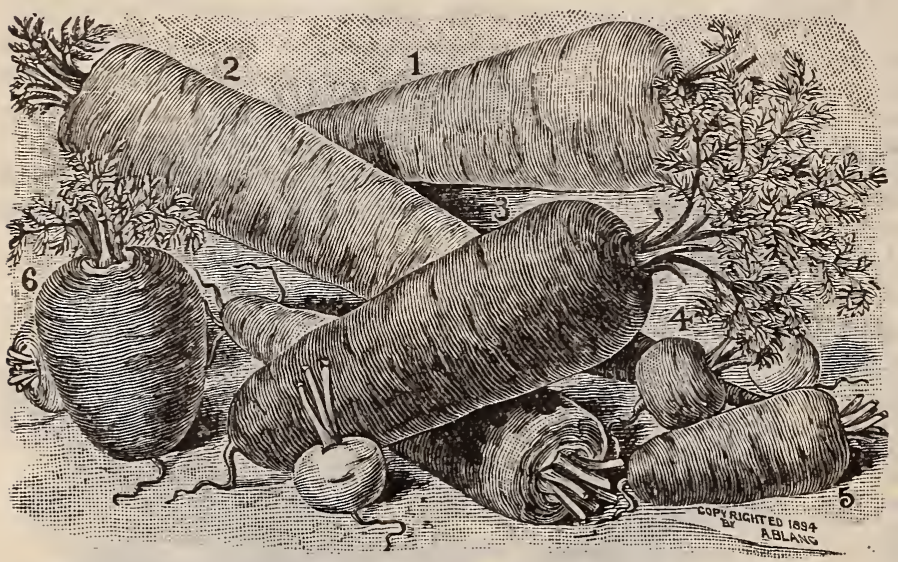

No. I.-Danver's Half-Long. No. 2.-Long Orange. No. 3.Scarlet Stump Rooted. No. 4.-French Forcing. No. 5.Scarlet Stump Rooted. No. 6.-Ox-Heart.
French Forcing. The best forcing variety. Red, small and round. Pkt. 5c; 1 oz. $10 \mathrm{c} ; 1 / 4 \mathrm{lb} .30 \mathrm{c} ; 1 \mathrm{lb}$. $\$ 1.00$.

Early Scarlet Short Horn. A favorite summer variety fine grain and flavor. Pkt 5s; 1 oz. 10c; $1 / 4$ 1b. 25 c; 1 lb. 75 c.

Ox-Heart or Half-Long Gue rande. This carrot is one of the most valuable, either for family use or market. It is an intermediate between the Half-Long and Horn varieties, attaining a diameter of three to four inches at the neck and of most beautiful shape and rich orange color. It is of extra quality and very productive. Pkt. 5c; 1 oz. 10c; $1 / 4$ 1b. 25c; 1 1b. 75 c.

Danver's Half-Long Orange. Probably the best of the balf-long type; broad. shouldered, cylindrical, admirable in color, fixed in habit, a wonderful producer; the best of all for the stock breeder, and valuable for the market gardener. With this variety, the planter secures the largest return to the acre with the least difficulty of harvesting. Pkt. 5c; 1 oz. 10c; 1// 1b. 20c; 1 lb. 60c.

Chantenay. A stump-rooted variety having an unusually broad shoulder. One of the very best carrots for either private use or market garden. Pkt. 5c; 1 oz. $10 \mathrm{c} ; 1 / 4$ 1b. 25c; 1 1b. $75 \mathrm{c} ; 5$ lbs., purchaser to pay express charges. $\$ 2.50$.

Ha1f-Iong Scarlet Stump Rooted. A little later than the Horn varieties, but equal to them in grain and quality. Has no hard core, and is first-class for either table or stock feeding. Pkt. 5c; 1 oz. 10c; $1 / 4$ 1b. 20c; 1 lb. 60c.

Improved Long Orange. The Long Red Carrot is an old stand-by for winter use. Pkt. 5c; 1 oz. 10c; $1 / 4$ lb. 20c; 1 lb. 60c.

Large White Belgi?n. The lower part of the root is white: that growing and exposed above ground, green. Principally used for stock feeding. Heavy cropper. Pkt. 5c; 1 oz. 10c: 1/4 1b. 20c; $1 \mathrm{lb} .50$ c; 5 lbs., purchaser to pay express charges, $\$ 1.80$.

Short White. A half-long, smooth variety, very heavy at the shoulder and tapering regularly to the point. Color, light green above ground, white below. Flesh white, solid and crisp. $A$ heavy cropper: profitable to grow for stock. P'at. 5c. 1 oz. 10c; 1/4 lb. 20c; $1 \mathrm{lb} .60 \mathrm{c}$.

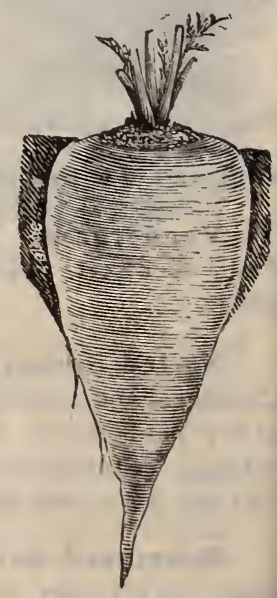

Short White. 


\section{CAULIFLOWER.}

One-half ounce of seed will produce 1000 plants.

Sow for early about the middle of September or October, in a bed of clean rich earth. Transplant into frames and cover with saches and shutters during severe weather, giving the plants light and air every mild day. Where this is not practicable, they may be had nearly as early by sowing the seed in a hot bed in January or February and when the plants are large enough transplant th, ee inches apart in boxes, or in the soil of another hot-bed, until the time to plant out, say from the 20th of March to the 10th of April. If hardened off by exposure, they are seldom injured by planting out as early as the ground can be properly prepared, into a berl of the richest earth, two and a half feet apart each way. Keep them well hoed, and bring the $\epsilon$ arth gradually up to their stems, watering freely in

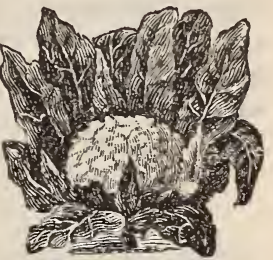

Extra Early

Dwarf Erfurt.

dry weather, and especiallv when they begin to head. Early Cauliflower succeeds best when brought to maturity before the summer heat sets in. The late varieties mature in the autumn, and are sown and managed similarly to winter cabbage.

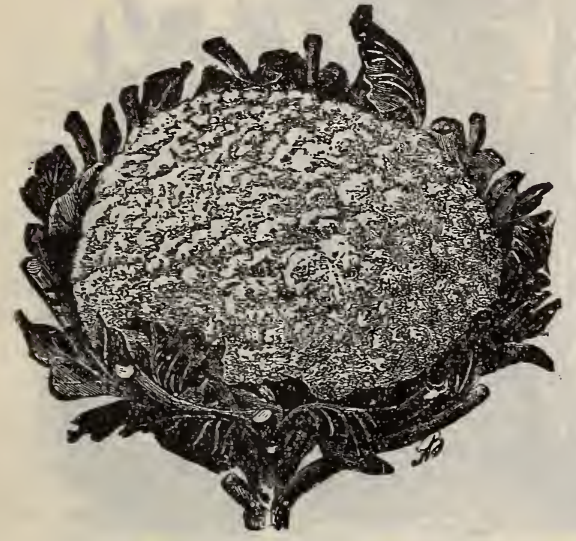

Extra Early Snowball.

Extra Early Dwarf Erfurt. Extra Selected. Remarkable for reliability in heading. Scarcely a plant fails to produce a good head. Very dwart, with solid, pure white heads of superior quality. One of the earliest. Pkt. $10 \mathrm{c}$ : $1 / 4$ oz. $65 \mathrm{c} ; 1$ oz. $\$ 2.00 ; 2$ oz. $\$ 3.75$; 1/4 1b. $\$ 6.00$.

Early Erfurt. Ordinary Strain. Pkt. 5c; 1 oz. $60 \mathrm{c} ; 2$ oz. $\$ 1.00 ; 1 / 41 \mathrm{~b}$. $\$ 600$.

Extra Early Snowball. Extra Selected. The earliest and handsomest of all caul.flowers. This is unquestionably the best type of cauliflower yet produced. It excels all others in earliness. Owing to the short outer leaves, it can be planted as close as eighteen inches apart. It is equally good for late planting. Pkt. 10c; 1/4 oz. 65c; 1 oz. $\$ 2.00 ; 2$ oz. $\$ 3.75$; $1 / 4$ lb. $\$ 6.00$.

Early Snowball. Ordinary Strain. Pkt. 5c; 1 oz. 60c; 2 oz. $\$ 1.00 ; 1 / 41$ b. $\$ 1.85$.

Early Paris. One of the popular white sure heading varieties, for either early or late. Pkt. 5c; 1 oz. 60c; 2 oz. $\$ 1.00$; $1 / 4$ 1b. $\$ 1.85$.

Large Late Algiers. A fine variety, and one of the best for late use; the heads remain firm and solid for a long time. The best late Cauliflower for this section. Pkt. 5c; 1oz. 75c; 2 oz. $\$ 1.35$; 1/4 1b. $\$ 2.50$.

Veitch's Autumn Giant. Vigorous in growth and very large; late. Pkt. 5c; 1 oz. 65 c; 2 oz. $\$ 1.20 ; 1 / 4$ lb. $\$ 1.75 ; 11$ b. $\$ 6.50$.

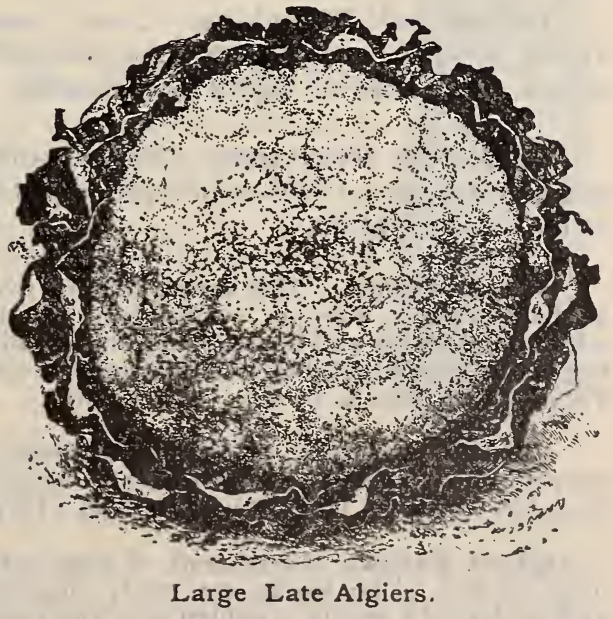

For Cauliflower Plants, see Vegetable Plants. 


\section{CELERY.}

Three ounces of seed to 100 yaris of row.

When two or three inches high, transplant to furrows; wlien eight to ten inches high, fill up the furrows, continuing at intervals to bill up untıl fully matured and blanched, taking care not to get earth between the stalks. The vigor and quality of the stalk are improved by partially topping when transplanting. Cultivate thoroughly and keep well watered.

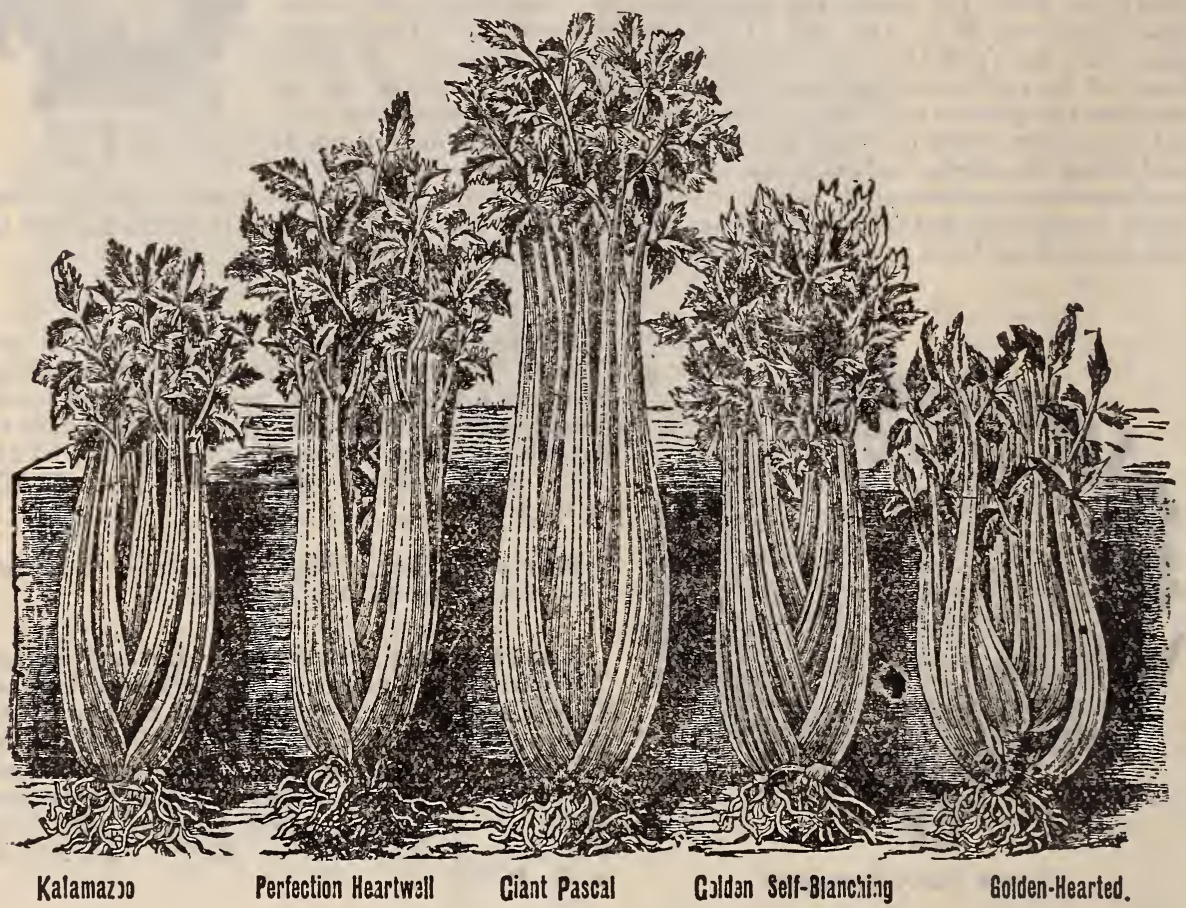

Golden Self-Blanching. Close, compact, handsome; heart, beantiful golden yellow; outer stalks, yellowish white; ribs perfectly solid, crisp and well-fiavorell; excellent keeper. A fine celery, highly recommended. Pkt. 5c; 1 oz. 25c; 1/4 1b. 80c; 1 lb. $\$ 2.50$.

Perfection Heartwell. The finest and largest of the winter varieties, either for the family or the market garden; of superior quality; heart, golden yellow. Pkt. 5c; $1 \mathrm{oz} .15 \mathrm{c}$; $1 / 4$ lb. 30c; 1 lb. $\$ 1.00$.

White Plume. This variety differs from many others, in the fact that it does not require banking - the stalk and the white inner leares and heart are naturally white. The hlanching is completed by tying uith matting or pressing the soil. Pkt.5c; 1 oz. 20c; 1/4 1b. 50c; 1 lb. $\$ 1.50$.

Golden Hearted. A variety of great value, splendid keeper, remarkable for its fine quility. Heart of briglit golden colur. Pkt. 5c; 1 oz. $15 \mathrm{c}$; $1 / 4$ lb. 35c; 1 lb. $\$ 1.15$.

Giant Pascal. Large, and of unusually rapir and rig. orous gruwth. The stalks are easily blanched. Firm, crisp and tender; of a beautifil golden tint, and possessing in a h gh degree the rich, nu'tv flavor, which is a sure indication of its superior quality. Pkt. 5c; 1 oz. 15c; $1 / 1 \mathrm{lb} .40 \mathrm{c} ; 1 \mathrm{lb}$. \$1.25.

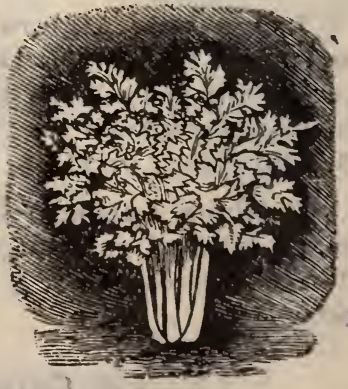

White Plume Celery. 
Pink Plume. The same as White Plume, except that the stalks are tinged with pink. It is of very attractive appearance and possesses the rich flavor and long-keeping qualities for which the red celeries are noted. Pkt. $5 \mathrm{c} ; 1 \mathrm{oz} .20 \mathrm{c} ; 1 / 41 \mathrm{~b} .50 \mathrm{c} ; 1 \mathrm{lb} . \$ 1.75$.

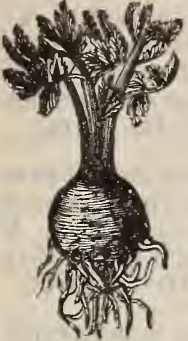

Celeriac

Kalamazoo. One of the best varieties. Half dwarf. Pkt 5c; $1 \mathrm{oz}$. 20c; $1 / 4$ 1b. 50c; 1 1b. $\$ 1.50$.

Giant White Solid. A standard variety and one of the largest. A strong, vigorous grower; crisp, tender and of good flavor; firm, and keeps longer than most others. Pkt. $5 \mathrm{c}, 1 \mathrm{oz} \cdot 15 \mathrm{c} ; 1 / 4$ lb. $40 \mathrm{c} .11 \mathrm{~b} . \$ 1.25$.

Boston Market. A cluster of small stalks. Very fine flavor. Pkt. 5 c; 1 oz. 15 c; $1 / 41$ b. 40 c; 11 b. $\$ 1.25$.

Celeriac, Turnip Rooted. Roots resemble turnips. This vegetable is esteemed in Europe for a salad. Pkt. 5c; 1 oz. $15 \mathrm{c} ; 1 / 41 \mathrm{~b} .50 \mathrm{c}$.

\section{For Celery Plants, See Vegetable Plants.}

\section{CORN.}

If ordered sent by mail, add 10 cents per pound for postage.

Two pounds of seed to 200 hills.

\section{SUGAR OR SWEET.}

The Sweet or Sugar varieties, being liable to rot in wet or cold ground, should not be planted until the ground has become warm. For a succession, continue planting every two weeks until the middle of July, in rich, well-manured ground, in hills three feet apart each way, covering about half an inch, or in rows four feet apart, and drill the seed so that the plants will stand eight inches apart in the rows.

Early Cory. The earliest sweet corn; the ears are much larger than any of the other early varieties; quality very fine. Pkt. 10c; $11 \mathrm{~b} .15 \mathrm{c} ; 10$ 1bs. $\$ 1.00$,

White Cob Cory. Similar to Early Cory, but has white cobs. Pkt. 10c; 1 1b. 15c; 10 1bs. $\$ 1.00$.

Early Minnesota. One of the earliest kinds of Sweet Corn. The ears are of the best quality, very productive. A popular early variety. Pkt. $10 \mathrm{c} ; 1 \mathrm{lb} .15 \mathrm{c} ; 10 \mathrm{lbs}$. $\$ 1.00$.

Crosby's Early. Early, and a great favorite. Rather small ears, but productive and of excellent quality. Pkt. 10c; $1 \mathrm{lb}$. $15 \mathrm{c} ; 10 \mathrm{lbs} . \$ 1.00$.

Early Concord. Ears large, having from ten to twelve rows on the ear; a superior variety, either for the market or family use; matures earlier than any other variety of equal size. Pkt. 10c; 1 lb. 15c; 10 lbs. $\$ 1.00$.

Perry's Hybrid. Stalk of medium height. The ears are large and grow long on the stalk. Kernels large, very white, tender and sweet. Pkt. 10 c; 11 b. 15 c; 10 lbs. $\$ 1.00$.

Hickox Improved. Medium early; valuable alike in the market or family garden or for canning. The ears are 12-rowed. Pkt. 10c; 1 lb. 15c; 10 lbs. $\$ 1.00$.

Black Mexican. One of the sweetest and most desirable for family use When dry, the kerneis are black. The corn, when in condition for the table, cooks remarkably white and is very tender. It is especially rich in sugary quilities. A good yielder. Pkt. 10c; 1 b. $15 \mathrm{c} ; 10$ bs. $\$ 1.00$.

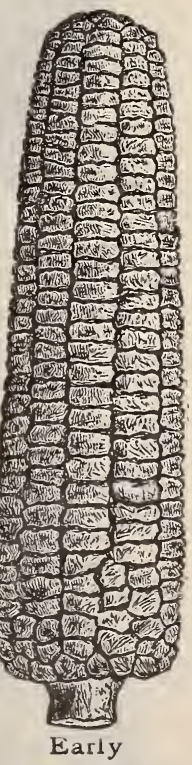

Minnesota.

Country Gentleman. This is one of the newer varieties that has proven itself worth planting. The ears are from eight to nine inches long and from three to four of them are borne on a stalk. The plant is six feet high and medium early. Pkt. 10c; 1 lb. 15c; 10 lbs. $\$ 1.00$. 


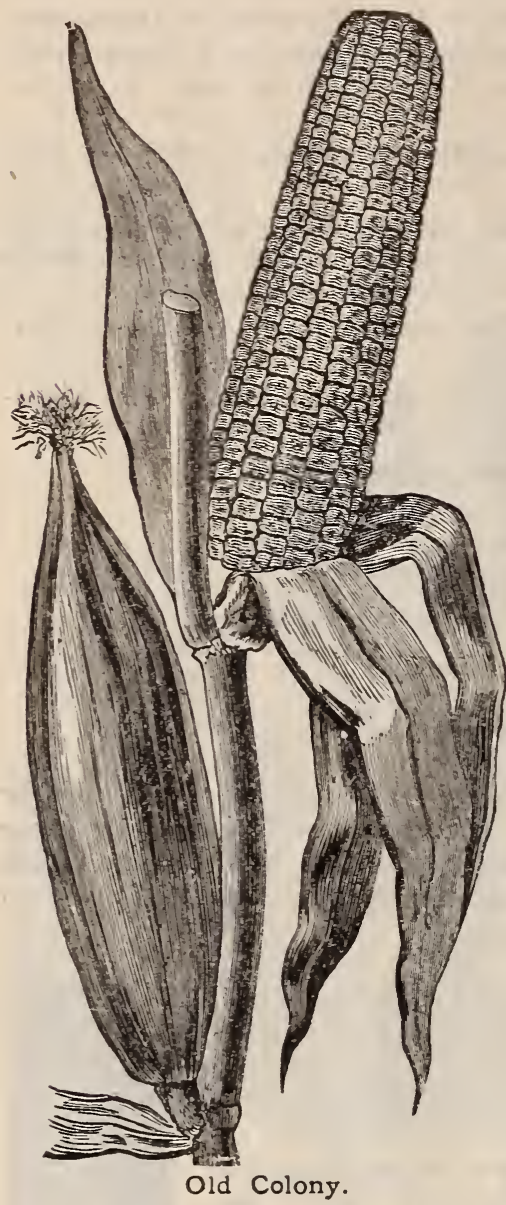

Old Colony. Fine large ears. This is perhaps the best variety for growing west of the Ca-cade mountains. Our seed is from a perfertly acclimated strain. Pkt. $10 \mathrm{c} ; 1$ 1b. $15 \mathrm{c} ; 10 \mathrm{lbs} \$ 1.00$.

Stowe1l's Evergreen. Remarkable for remaining a long time in a fresh condition, suitable for the table. Hardy and productive, and the best late variety for general use. Also rery tender and sugury. Plt. $10 \mathrm{c} ; 1$ lb. $15 \mathrm{c} ; 10$ lbs. $\$ 100$.

Mammoth Sweet. Produces the largest ears of any rariety, which are filled to the tip with large, full kernels; sweet, tender, delicious. A popular variety for canning; also good for market or home use. Pkt. $10 \mathrm{c} ; 1 \mathrm{lb} .15 \mathrm{c} ; 10 \mathrm{lbs} . \$ 1.00$.

Early Adam's or Burlington. A rery early variety, not a sweet corn but white and tender, and extensively used for the table. 1 1b. 15c; 10 lbs. $\$ 1.00$.

\section{FIELD VARIETIES.}

Early Red Blazed. An early, hardy variety, enduring considerable cold. Stalks of merlium height, having few suckers. The ears are long, eight-rowed, and well filled. Kernels bright yellow at the base shading into red at the tips. 1 1b. 10 c; 10 lbs. 80c.

King Philip. A very early variety for field corn. Ears ten to twelve inches long, eightrowed, large reddish kernels. $1 \mathrm{lb} .10 \mathrm{c} ; 10 \mathrm{lbs}$. $80 \mathrm{c}$.

Early Canada (Flint). Also known as the Yellow Flint. A rapid-growing early yellow kind, and, on this account, used much for replanting. Superior where the seasons are short. $1 \mathrm{lb} .10 \mathrm{c}$; $10 \mathrm{lbs} 80 \mathrm{c}$.

Early White Flint. A variety much used for making hominy. Productive, early, and of beautiful appearance. 1 lb. $10 \mathrm{c} ; 10 \mathrm{lbs}$. 80c.

Champion White Pearl. A large, white, late Dent variety, pearly white kernels. 11b. $10 \mathrm{c} ; 10 \mathrm{lbs}$. $70 \mathrm{c}$.

Southern Fodder Corn. Best for green feed. 1 lb. 10c; 10 lbs. $75 \mathrm{c}$.

Pop Corn. Small white. $1 \mathrm{lb} .15 \mathrm{c}$.

Pop Corn. Rice. 1 lb. $15 \mathrm{c}$.

\section{BROOM CORN.}

Requires soil and culture similar to corn, but to obtain the best quality of brush, the land should be rich, and well and deeply cultivated. Usually planted in drills three and a half feet apart, and thinned to four to six inches apart in the row.

Improved Evergreen. An improvement on the Common Evcrgreen. The result of many years' careful selection. Does not grow as tall as the old variety. The brush is fine, and of a light green tint. Pkt. $5 \mathrm{c} ; 1 \mathrm{lb} .20 \mathrm{c} ; 10 \mathrm{lbs} . \$ 1.00$.

\section{CRESS OR PEPPER GRASS.}

The leaves, when young, bave a warm pungent taste, and are used as salad, either alone or mixed with other salad plants. The seed of the Curled rariety germinates quickly and the plants grow rapidly. As they are milder and tenderer when young, the seed should be sown at intervals of ten to fifteen days, beginuing as soon as the ground can be prepared.

Curled. The best variety. Upland. Pkt. 5c; 1 oz. 10c; 1/4 1b. 25c.

Water. Should be sown near the edge of running streams. It has a very pleasant and agreeable taste. Perennial aquatic plant. Pkt. 5c; 1 oz. $40 \mathrm{c}$. 


\section{CUCUMBER.}

One ounce of seed to 75 hills.

For very early Cucumbers, sow a few seeds in a hot bed upon pieces of sod (grass side down) so that they can be readily removed to transplant in the open ground. For general crop, sow as soon as all canger of frost is over. They succeed best in a warm, moist, rich loamy soil. Continue planting at intervals for a succession, in hills about four feet apart each way. The hills should be previously prepared with a shovelful of well-rotted manure. Thin out to four of the strongest plants to each hill. The Cucumber should be gathered when large enough for use, whether required or not. If left to ripen it destroys the productiveness. For pickles, plant from June until the middle of July

Nichol's Medium Green. A valuable variety of medium size, straight and well formed and abundantly productive. Color, dark green; fresh, crisp and tender, and of good flavor. It is specially adapted for pickling purposes and for slicing. Grows very quickly. Pkt. 5c; 1 oz. 10c: 1/4 1b. 20c; 1 lb. 55c.

Cool and Crisp. One of the newer varieties. The fruit is long, dark green, with white spines. The flesh is crisp and tender. Pkt. 5c. 1 oz. 10 c; $1 / 4$ lb 20 c; 1 lb. 60 c.

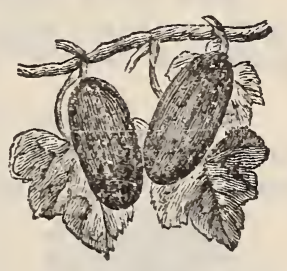

Early Russian. The earliest and hardiest productive variety. Nichol's Medium The fruit is of small size and produced in pairs. Pkt. 5c; 1 oz. 10c; Green Cucumber. $1 / 4$ 1b. 25c; 1 1b. 75 c.

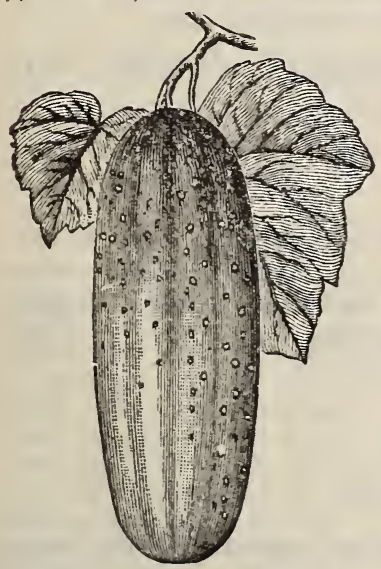

Early Frame, or Short Green. A good old popular variety, of medium size, straight and excellent for table use or pickling when young. Pkt 5c; 1 oz. 10c; 1/4 1b. 20c; $1 \mathrm{lb} .50 \mathrm{c}$.

Early Cluster. A productive early kind. The fruit which is not large, is borne in clusters, and is crisp and of good flavor. Pkt. 5c; 1 oz. 10c; 1/4 1b. 20c; 1 lb. 50c.

Peerless White Spine. Even in shape at both ends and uniform in size and color. In demand for pickling; also a fine market and table sort. Pkt 5c; 1 oz. 10c; $1 / 41 \mathrm{~b}$. 20c; 1 lb. 55c.

Boston Pickling. The best short pickling variety, of fine form and flavor; enormously productive; crisp and tender. Largely used by the pickle factories in this section. Pkt. 5c; 1 oz. 10c; $1 / 4$ 1b. 20c; 1 1b. 55c.

Peerless White Spine.

Chicago, or Westerfield Pickling. A decided favorite with Chicago market gardeners. Fruit of medium length, pointed at both ends, with large and prnminent spines. Color deep green. Pkt. 5c; 1 oz. 10c; 1// 1b. 20c; 1 1b. 60c.

Improved Iong Green. The leading long green variety for pickling; of excellent quality and productiveness; fruit dark green, firm and crisp; one of the best for slicing green. It can be gathered at any size, while young, for pickles. Pkt. $5 \mathrm{c} ; 1 \mathrm{oz} .10 \mathrm{c} ; 1 / 41 \mathrm{~b} .20 \mathrm{c}$; $1 \mathrm{lb} .55 \mathrm{c}$.

Small Gherkin or Burr. Also known as the West India, or Jerusalem Pickle; used for pickling while young and tender. Pkt. $5 \mathrm{c} ; 1$ oz. $10 \mathrm{c} ; 1 / 4$ 1b. $30 \mathrm{c}$.

Japanese Climbing. The vines are healthy and vigorous and their strong tendrils enable them to climb poles or fences. Quality excellent either for pickling or slicing. Pkt. 5c; $1 \mathrm{oz} .15 \mathrm{c} .1 / 4 \mathrm{lb}$. $35 c$.

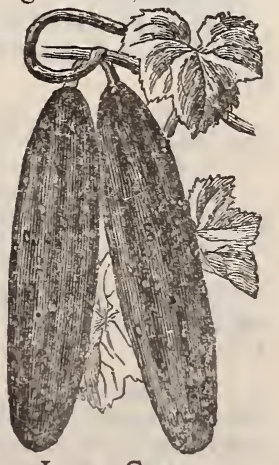

Long Green.

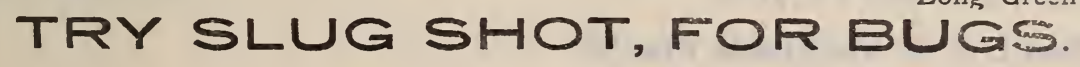




\section{EGG PLANT.}

Should be started in a hot-bed and transplanted when the weather is settled and the ground thoroughly warm. They will thrive with the same treatment as that given the tomato.

Early I,ong Purple. Fruit rather long, usually largest at the blossom end; a hardy kind, productive and of good quality. Pkt. 5c; 1 oz. 20c; 1/4 1b. 60c; 1 lb. $\$ 2.00$.

New York Improved, I arge Purple. The leading market variety. Large, round, dark, excellent, and the most productive. Pkt. 5c; 1 oz. $40 \mathrm{c} ; 1 / 41 \mathrm{~b} . \$ 1.25$.

Black Pekin. Oval round, of medium size, very dark, glossy and handsome. Flesh, delicate. Prized for the family garden. Pist. 5c; 1 oz. 30c; $1 / 4$ lb. $\$ 1.00$.

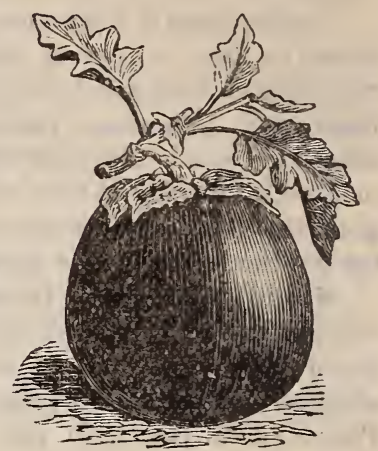

New York Improved.

\section{ENDIVE.}

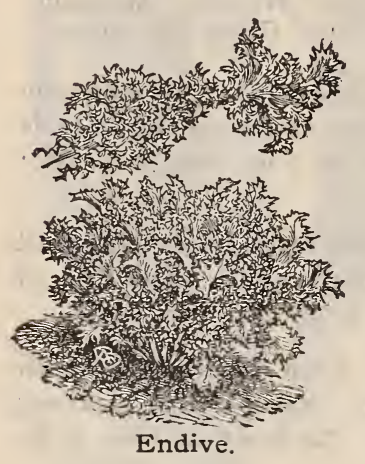

This is a hardy vegetable, cultivated principally for a winter salad. Sow from May until August for a succession of crops; tie the leaves closely together to blanch them.

Green Curled. Standard sort for fall and winter. Pkt. 5c; 1 oz. 10c; $1 / 4$ 1b. 30 c; 1 lb. $\$ 1.00$.

White Curled. For early use. Pkt. 5c; J oz. 15c; $1 / 4$ 1b. 40 c; 11 lb. $\$ 1.40$.

Broad Ieaved Batavian. (Escarolle.) Fias broad, thick leaves, which form a large, loose head. Fine for soups and stews. If blanched by tying the outer leaves together, it makes an excellent table salad. Pkt. 5c; $1 \mathrm{oz} .15 \mathrm{c} ; 1 / 4 \mathrm{lb}$. 35 c; 11 b. $\$ 1.25$.

\section{KALE, OR BORECOLE.}

One ounce of seed to 100 yards of row.

While this vegetable may be grown in almost any soil, yet the richer the soil the larger the crop. Not desirable until touched by frost. Sow about the latter part of April and transplant in June. Cultivate the same as cabbage.

Dwarf Green Curled Scotch. Very dwarf and spreading. Best strain. Pkt. $5 \mathrm{c} ; 1$ oz. $10 \mathrm{c} ; 1 / 41 \mathrm{~b} .30 \mathrm{c} ; 1 \mathrm{lb}$. $\$ 1.00$.

Tall Scotch Curled. Bright green, snreading and beautifully curled. Pkt. $5 \mathrm{c} ; 1 \mathrm{oz} .10 \mathrm{c} ; 1 / 4 \mathrm{~b}$. $30 \mathrm{c} ; 1 \mathrm{lb}$. $\$ 1.00$.

Siberian. (German Greens.) A variety extensively grown for winter greens. It is uniformly dwarf, green curled. Pkt. $5 \mathrm{c} ; 1$ oz. $10 \mathrm{c}$; $1 / 4 \mathrm{lb}$. $30 \mathrm{c} ; 1$ lb. $\$ 1$. (10.

Jersey Winter Kale or Cow Cabbage. Leaves make valuable winter feed for cattle. Ykt. $5 \mathrm{c} ; 1 \mathrm{oz} .15 \mathrm{c} ; 1 / 4 \mathrm{lb} .40 \mathrm{c}$; $1 \mathrm{lb} . \$ 1.25$.

Mosbach. In height between the Dwarf Scotch and the Extra Dwarf. Leaves bent upwards, light yellow gretn, double curled, white narrow ribs and veins, very showy. Pkt. 5c; 1 oz. $15 \mathrm{c} ; 1 / 4$ lb. $40 \mathrm{c}$; 1 lb. $\$ 1.25$.

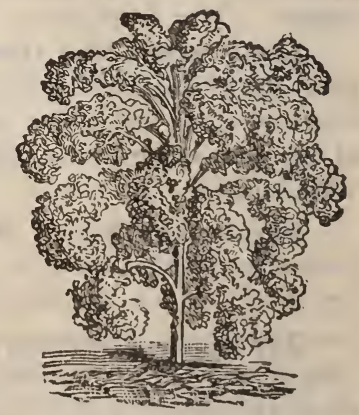

Tall Scotch.

See List of Vegetable Plants. 


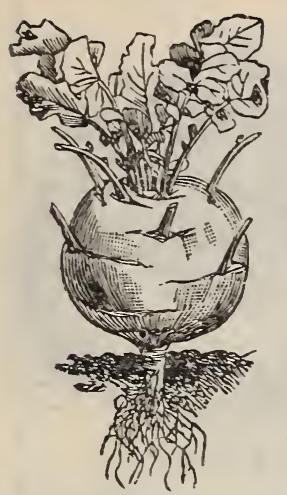

Kohl Rabi.

\section{KOHL RABI.}

A vegetable intermediate between the cabbage and turnip. Sow in spring in rows eighteen inches apart, afterwards thinning the plants to eight or ten inches. If the weather is suitable, the thinnings may be planted; but it is considered difficult to transplant. Keep the weeds down, and when the thickened stem above ground is two or three inches through, they are fit to eat and should be used at once, being tough when old. They are cooked same as turnips.

Early White Vienna. Handsome and delicate white bulb Pkt. 5c; 1 oz. 15c; 1/4 1b. 50c.

Eariy Putple Vienna. Purple ball. A good kind. Pkt. 5c; 1 oz. 15 c; $1 / 4$ lb. 50 c.

\section{LEEK.}

The Leek belongs to the onion family. Prized for soups, and is thought for this purpose to be superior to onions. Cultivation similar to that for onions, but hill up about the neck to blanch it.

Large Rouen, or American Flag. A favorite large American market sort. Pkt. 5c; 1 oz. $15 \mathrm{c} ; 1 / 41 \mathrm{~b} .50 \mathrm{c} ; 11 \mathrm{~b} . \$ 1.5 \mathrm{U}$.

Monstrous Carenton. Rather larger than the Flag, but very tender and mild on account of its rapid growth. Pkt. 5c; 1 oz. 20c; 1/4 1b. 50c; 1 1b. $\$ 1.50$.

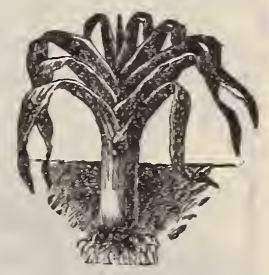

Large Rouen Leek.

\section{LETTUCE.}

Two ounces of seed to 100 yards of row.

Lettuce thrives best in good, rich, moist ground, and is a universal favorite, is almost free from insects and disease, which makes it of easy culture to every one. To grow fine head lettuce for the principal early crop, sow the seed in September in the open ground. Transplant, when large enough, into cold frames, and protect the plants during the winter in the same manner as for early cabbage, then set the plants out early in April: or sow the seeds in hot heds in February or March, and afterward. for early salad, transplant into a sheltered border with a southern exposure. For successive crops, sowings may be made in open ground as early as the spring opens, and continued until July. Always sow thinly and thin out well, or the plants will not be strong. The last spring and summer sowings had better be grown where sown, being thinned out to stand ten or twelve inches apart, or transplanted into a cool, moist place. When wanted for cutting young, as a salad, sow rather thickly in rows or broadcast.

Simpson's Black Seeded. A variety of the Curled Simpson, but growing much larger and of excellent quality. One of the best for forcing. Pkt. 5c;1oz. 10c; $1 / 4$ 1b. 30c; 1 1b. 90c.

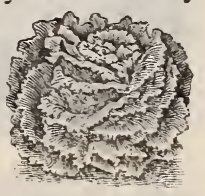

Simpson's.

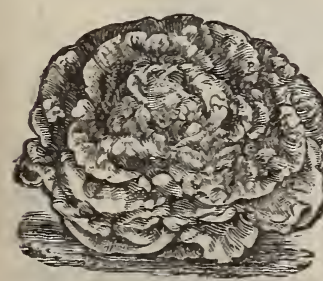

Tennis Ball.

Simpson's Early Curled. A leading early market variety. Forms a dense mass of finely-curled and wrinkled leaves that are excellent and tender and do not wilt readily. A good market kind. Pkt. 5c. 1 oz. 10c; 1/4 1b. 30c; 1 1b. 90c.

Early Prize Heax. Heads of mammoth size. Remains tender and crisp throughout the season. Very hardy. Pkt. 5c; $1 \mathrm{oz} .10 \mathrm{c} ; 1 / 4 \mathrm{H}$ 1b. $30 \mathrm{c} ; 1 \mathrm{lb} .90 \mathrm{c}$.

Early Tennis-Bail, Black Seeded. Well-formed heads, hardy aud crisp, of excellent quality. One of the earliest of the heading varieties. Pkt. $5 \mathrm{c} ; 1$ oz. $10 \mathrm{c} ; 1 / 4$ 1b. $30 \mathrm{c} ; 1$ lb. $90 \mathrm{c}$. 
Tilton's White Star. Forms a large, loose heal of excellent quality, which blanches well. The leaves are broader, thicker and darker than the Black Seeded Simpson, and it grows larger and more rapidly. Good for forccing and early planting out doors. Does not run to seed quickly. Pkt, $5 \mathrm{c} ; 1 \mathrm{oz} .15 \mathrm{c} ; 1 / 4 \mathrm{lb}$. $40 c ; 1$ lb. $\$ 1.25$.

Hanson's Head. The leading curled heading variety, of large size, sweet, tender and crisp, even to the outer leaves. Of a beautiful green without and white within. Free from anv bitter taste, either for summer or forcing. Pkt. 5 c; 1 oz. 10 c; $1 / 41$ lb. 30 c; 11 b. 90 c.

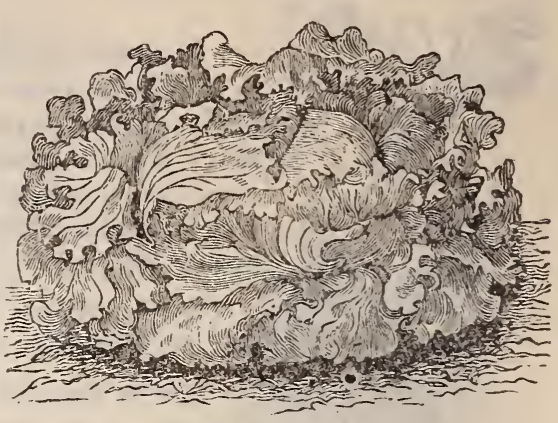

Hanson's Head.

Philadelphia Butter. Forms a close, firm head with few outer leaves. A fine variet $y$ for the family or market garden. Pkt. 5c; $1 \mathrm{oz} .10 \mathrm{c} ; 1 / 4 \mathrm{lb} .30 \mathrm{c} ; 1 \mathrm{lb} .90 \mathrm{c}$.

Brown Dutch. Forms a large, solid head, somewhat coarse in appearance, but hav ing the inner leaves well blanched, sweet, tender and of good flavor. Outer leaves tinged with brown. Very hardy. Pkt. 5c; 1 oz. $15 \mathrm{c} ; 1 / 41 \mathrm{lb} .30 \mathrm{c} ; 11 \mathrm{~b} . \$ 1.00$.

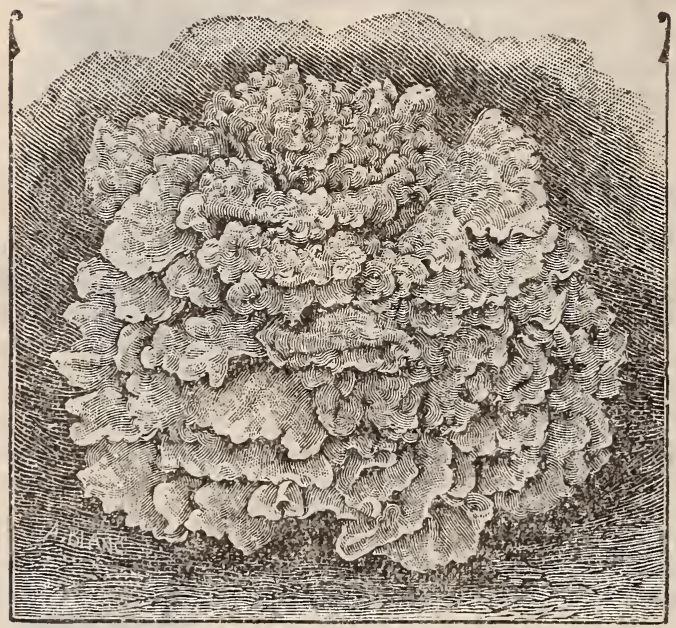

Grand Rapids.

Grand Rapids Forcing. Large tender heads; more extensively used for early forcing than any other variety. Pkt. $5 \mathrm{c}: 1 \mathrm{oz} .15 \mathrm{c} ; 1 / 4$ 1b. $30 \mathrm{c}$; $1 \mathrm{lb} . \$ 1.00$.

Denver Market. The special characteristic of this sort is that it has a beautiful, curled, savoy-like leaf which gives it a very attractive appearance. It is a drumhead variety of very excellent quality, and extremely early, Pkt. 5c; 1 oz. 10c; $1 / 4$ 1b. $30 \mathrm{c} ; 1 \mathrm{lb}$. 90c.

I,arge Drumbead or Victoria Cabbage. The largest of the lieading lettuces. Plant very large, forming an immense loose head; bright green without and light green or white withın. Pkt. $5 \mathrm{c} ; 1$ oz. $10 \mathrm{c} 1 / 4 \mathrm{lb} .30 \mathrm{c}$; $1 \mathrm{lb} .90 \mathrm{c}$.

White Paris Cos. A distinct variety, forming oblong, upright heads, largest near the top. It is hardy, tender and crisp, and does not run to seed as quickly as some other Cos varieties, of which it is generally considered the best. Pkt. $5 \mathrm{c} ; 1$ oz. 15c; 1/4 1b. $30 \mathrm{c} ; 1 \mathrm{lb} .90 \mathrm{c}$.

\section{MELON-MUSK.}

One ounce of seed to 75 hills.

Melons thrive the best in a light, enriched soil. Plant early when danger of frost is past and the ground has become warm and dry, in hills six feet apart each way, Previous to sowing the seed, inix a few shovelfuls of well-rotted manure in each hill; then plant ten to tweive seeds. After ail danger of bugs is over, thin out to three plants per hill. When about one foot long, pinch off the tips to make them brauch, as it strengthens the growth of the vines and makes the fruit mature earlier. Be careful not to plant pumpk in or squashes near them, as they will hybridize. 


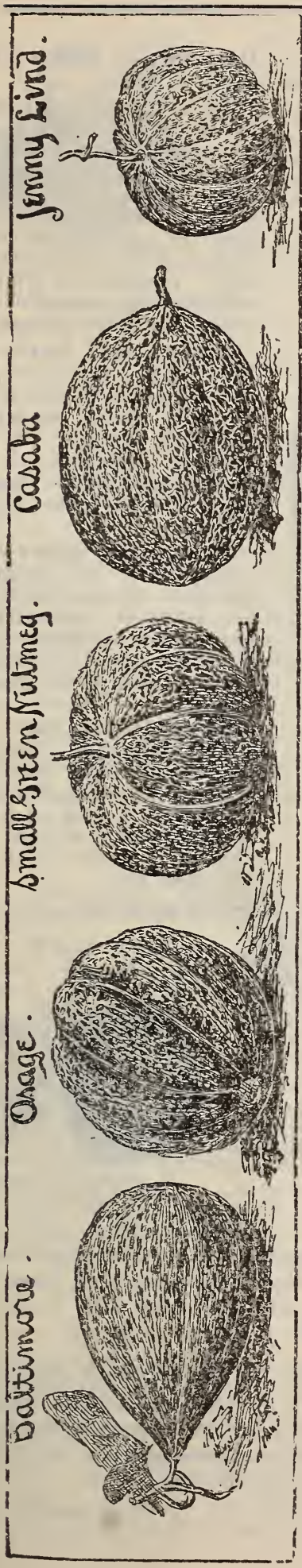

GREEN FLESHED.

Jenny Lind. Small, but very early and of good quality; green flesh. Pkt. 5c; 1 oz. 10c; 1/4 lb. 20c; I 1b. 6oc.

Early Baltimore, or Acme. A good sized, oval round, very desirable variety. The flesh is thick, highlyflavored and sweet. Pkt. 5c; 1 oz. 10c; 1/4 1b. 20c; $1 \mathrm{lb}$. $60 \mathrm{c}$

Cosmopolitan. A new variety. Flesh green, firm, sweet and uniformly high flavored. Pkt. 5c;1 oz. 10c; 1/4 1b. 25c; 1 lb. 75c.

Small Green Nutmeg. From the uniformity in size, it is a very profitable variety for field culture for the market shaped round, medium size, flattened at each end, heavily netted. Pkt. 5c; 1 oz. 10c; 1/4 1b. 20c; 1 lb. 60c.

Extra Early Hackensack. One of the most popular varieties of Musk-melon grown by market gardeners. It attains a large size, is round in shape, and flattened at the ends. Is of a most delicious flavor and wonderfully productive. Pkt. $5 \mathrm{c} ; 1$ oz. $10 \mathrm{c} ; 1 / 4 \mathrm{lb}$. 25c; 1 1b. 75c.

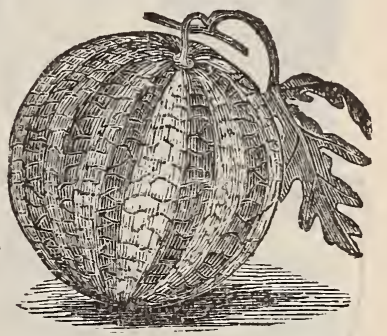

Montreal Nutmeg.

Montreal Nutmeg. Grows to an immense size, flattened at bo $h$ ends, very thick flesh and rich in flavor. Pkt. 5c; 1 oz. 10c; $1 / 4$ lb. 20c; 1 lb. 60c.

Skillman's Netted. Very early and of small size; flesh light green, very thick and sweet. Shape varies from oval to round. Pkt. $5 \mathrm{c} ; 1$ oz. $10 \mathrm{c} ; 1_{1}^{1 / \mathrm{l}} 1 \mathrm{~b} .20 \mathrm{c} ; 1 \mathrm{lb} .70 \mathrm{c}$.

Casaba. Of extraordinary s'ze and delicious flavor, usual weight from twelve to fifteen pounds. Late, oval and netted: Pkt. 5c; 1 oz. $10 \mathrm{c} ; 1 / 4$ lh. $25 \mathrm{c} ; 1$ 1b. $75 \mathrm{c}$.

\section{YELIOW FLESHED.}

Osage, or Miller's Crears. The finest-flavored melon in cultivation, and the best r.elon grown for the market gardener, for the trucker, for the farmer, for the small planter. Without question, the sweetest of all melons. The flesh is of a rich salmon color, very sweet and melting in quality, and is so rery thick that the melon is almost solid, the seed cavity being remarkably small. Pkt. 5c; 1 oz. 10c; 1/4 lb. 20c; 1 1b. 60c.

Orange Christiana. Very large, green skin; yellow flesh, delicious flavor, and is an excellent melon. Pkt. 5c; $1 \mathrm{oz} 10 \mathrm{c} ; 1 / 4$ lb. 20c; $11 \mathrm{~b}$. 60c.

Surprise. The earliest of the yellow-fleshed varieties. Oval round, medium size, rather smooth, flesh bighly fla vored and delicious. Excellent for early marketing. Pkt. $5 c ; 1$ oz. 10 c; 1/4 1b. 20c; 1 lb. 60c.

Large Yellow Cantaloupe. An oval variety, good sized, skin yellow, marbled with green; flesh salmon colored, sweet, highly perfumed and of good flavor; early and productive. Pkt. $5 \mathrm{c} ; 1 \mathrm{oz} .10 \mathrm{c} ; 1 / 41 \mathrm{~b} .20 \mathrm{c} ; 1 \mathrm{lb} .60 \mathrm{c}$.

Emerald Gem. Fruit medium sized, slightly flattened at the ends. Flesh deep salmon yellow, highly flavored. One of the leading varieties. $\mathrm{Pkt} .5 \mathrm{c} ; 1 \mathrm{oz} .10 \mathrm{c}$; $1 / 4$ 1b, 20c; 1 1b. 75 c.

Write For Special Prices on Larger Quantities of Melon Seeds. 


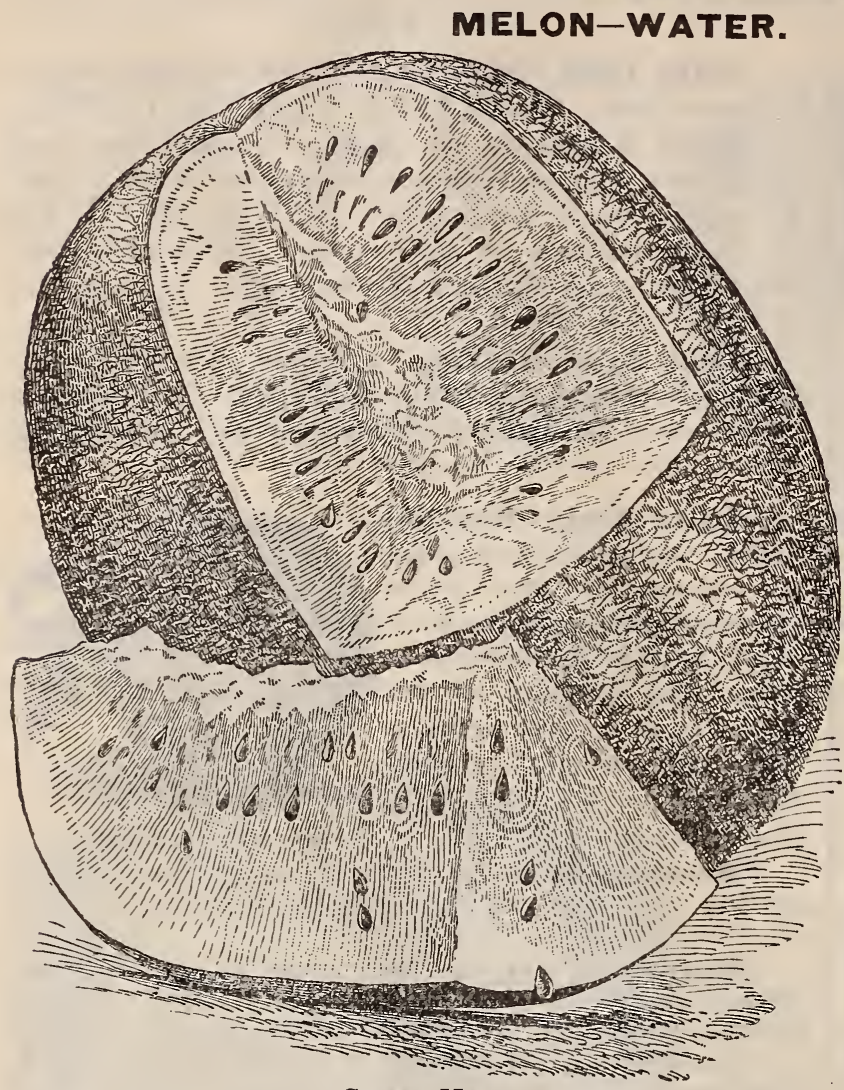

One ounce of seed to 30 hills.

The water-melon is prized for its refreshing coolness in warm weather, and delicious sweetness. They thrive best in rather sandy soil, well manured, and planted in hills eight feet apart each way. Prepare the hills and treat the same as described for Musk-melons.

$P$ hinney's Early. Very early, productive, and keeps well; bright red flesh, sweet, tender and well flavored; particularly valuable for market gardeners. Pkt. $5 \mathrm{c} ; 1$ oz. $10 \mathrm{c} ; 1 / 4$ 1b. $15 \mathrm{c}$; $1 \mathrm{lb} .45 \mathrm{c}$.

Hungarian Honey. A very early sort from Hungary. Fine for northe r n latitudes: perfectly round, flesh brilliant red; seeds very small. Pkt. 5c; 1 oz. 10 c; $1 / 4$ lb. 25 c; 1 lb. $75 \mathrm{c}$.

Sweet Heart. Early, large, bright skin Flesh bright red, firm, solid, but very tender, melting and sweet. A long keeper and splendid shipper. Pkt. $5 \mathrm{c} ; 1$ oz. $10 \mathrm{c} ; 1 / 4 \mathrm{lb}$. Sweet Heart. 20c; 1 lb. 60c.

Black Spanish. A black seeded variety, large, round, very dark green skin; flesh red, sweet and delicious. Pkt. $5 \mathrm{c} ; 1 \mathrm{oz} .10 \mathrm{c} ; 1 / 4 \mathrm{~b} .20 \mathrm{c} ; 1 \mathrm{lb} .50 \mathrm{c}$.

Dark Icing. A distinct variety, resembling in size and shape the Ice Cream or Peerless, but is lighter in color and faintly mottled. The rind is not thick but rather firm. The flesh is remarkably juicy, sweet and delicious. Pkt. 5c; 1 oz. 10c; 1/4 1b. 20c; 1 lb. 50c.

Iight Icing, or Jordan's Gray Monarch. A very large variety, light green in color; flesh light red, tender and sweet. Considered by many the best melon grown. Pkt. 5c; $1 \mathrm{oz}, 10 \mathrm{c} ; 1 / 4 \mathrm{lb}$. $20 \mathrm{c} ; 1$ lb. $45 \mathrm{c}$.

Kentucky Wonder. Oblong in shape; skin dark green; flesh a beautiful scarlet color; crisp and not tough, rich and sugary flavor, always firm, very solid and never mealy. Pkt. 5c; 1 oz. 10c; 1/4 $1 \mathrm{~b}$. 20c; 1 1b. 50c.

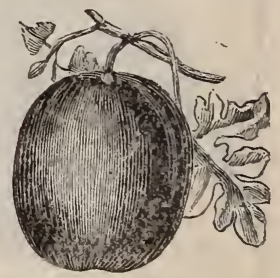

Dark Icing.

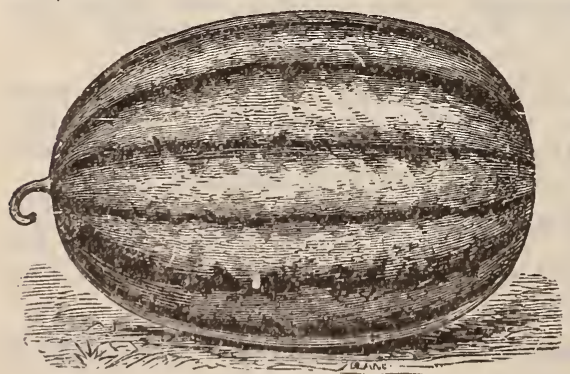

Cuban Queen.
Mountain Sweet. A general favorite with melon growers; large, and oblong; dark green; thin rind; flesh red, solid, rich and sweet. Pkt. 5c; 1 oz. 10c; 1/4 1b. 20c; 1 lb. 50c.

Cuban Queen. The flesh is dark red and of excellent flavor. It has a very tough rind, and carries in good condition without breakage. One of the largest varieties grown. Pkt. 5c; 1 oz. $10 \mathrm{c} ; 1 / 4$ lb. $15 \mathrm{c} ; 1$ 1b. $50 \mathrm{c}$. 


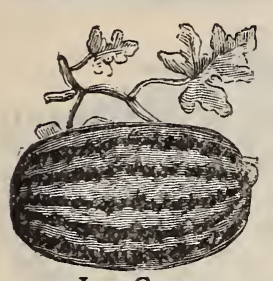

Ice Cream

Ice Cream, or Peerless. White seeded; fruit of medium size, nearly round; color, pale green; thin rind, flesh solid; scarlet, crisp, and of a delicious flavor. Pkt. $5 \mathrm{c} ; 1 \mathrm{oz} .10 \mathrm{c}$ : $1 / 4 \mathrm{lb}, 20 \mathrm{c}$; $1 \mathrm{lb} .50 \mathrm{c}$.

Kolb's Gem. A profitable variety to grow for shipping. Vines of medium size, but remarkably vigorous and healthy. Fruit of the largest size, round or slightly oval, marked with irregular mottled stripes of dark and light green in sharp contrast. Outer rind or shell exceedingly hard and firm. Flesh bright red. Pkt. 5c; $1 \mathrm{oz} .10 \mathrm{c}$; $1 / 4$ 1b. 20c; 1 1b. 50c.

Citron Red-Seeded. For preserving. Small, round, flesh white and solid. Pkt. 5c; 1 oz. 10c; 1/4 1b. 20c; 1 1b. 60c.

\section{Write for Special Prices on Larger Quantities of Melon Seeds.}

\section{MUSHROOM SPAWN.}

The Mushroom is an edible fungus that does not produce seed, but is propagated from the white fibres resembling roots, that spread from the base of the stool, termed spawn. They are grown in cellars, caves, or wherever a uniform temperature of 60 to 70 degrees can be maintained. Make beds of fermerting manure, which should be large and deep enough to acquire a heat of about 70 degrees. When at the proper temperature, insert bits of Spawn at intervals. As soon as signs of growth appear, place two inches of soil over them and cover all with straw. Water is used if necessary, which should be warmed to the temperature of the bed. Mushrooms appear in six or eight weeks, and should be collected when at the proper size for the table.

French. Mushrooms obtained from this spawn are very

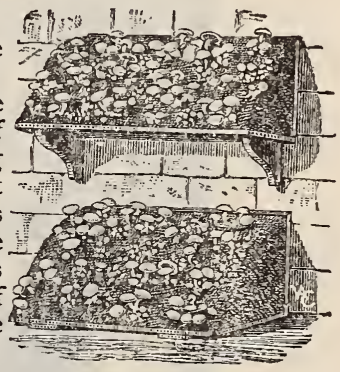

Mushrooms. highly esteemed. In 3-1b. boxes, per box $\$ 1.75$.

English. In bricks, 30c. per 1b. postpaid; by express, 20c. per lb.

\section{MUSTARD.}

Used alone as "greens," or with cress as salad. Sow any time in the spring, in rows, and thin out as necessary.

White English. Leaves mild, tender when young, and generally preferred for salad. The seed, which is light yellow, is largely used with pickles and in salads. Pkt. $5 c ; 1$ oz. 10c; 1/4 1b. 15c; 1 1b. 30c.

Southern Giant Curled. Very large leaves. Pkt. 5c; 1 oz. 10c; 1/4 1b. 25c; 1 1b. 70c.

NASTURTIUM.

The Nasturtium is very popular as an ornamental plant and also for the table. The leaves, when young, are used as salad, and also in connection with the flowers for garnishing, and the seed for capers and pickles, for which purpose they should be gathered while green and tender.

Tall Mix $\circ$ d. Mostly used, as they produce the largest seeds. They have also very handsome foliage and beautiful flowers. Pkt. 5c; $1 \mathrm{oz} .15 \mathrm{c} ; 1 / 41 \mathrm{~b} .30 \mathrm{c}$.

\section{For other varieties, see Flower List.}

\section{OKRA, OR GUMBO.}

Very extensively grown in Southern states. Its long pods when young are used for flavoring soups, stews, etc., and are considered very nutritious. Sow in drills from two to three feet apart, and thin out from nine to twelve inches apart in the row. Two ounces of seed to 100 yards of row.

Improved Dwarf Green. Very early, with long green slender pods. Pkt. 5c; $1 \mathrm{oz} .10 \mathrm{c} ; \mathrm{1} / 4 \mathrm{lb} .20 \mathrm{c} ; 1$ lb. $60 \mathrm{c}$.

White Velvet. The pods are smonth or very slightly ribbed, large, remain tender a long tim $\approx$, and are of the best quality. Pkt. $5 \mathrm{c} ; 1 \mathrm{oz}$. $15 \mathrm{c} ; 1 / 41 \mathrm{~b} .25 \mathrm{c} ; 1 \mathrm{lb} .75 \mathrm{c}$. 


\section{ONION.}

If ordered by express or freight, deduct 10c. from single pound price.

Sow thinly in drills one foot apart and about one-quarter inch deep, in March or early in April, thinning them to stand three or four inches apart in the drills and keeping them well hoed and free from weeds. For main crop, the Yellow Danrers and Red Wethersfield are usually preferred. They delight in strong, rich, deep, loamy snil. The ground should be deeply dug and heavily manured with well-rotted manure, when they succeed well if grown successive years on the same ground.

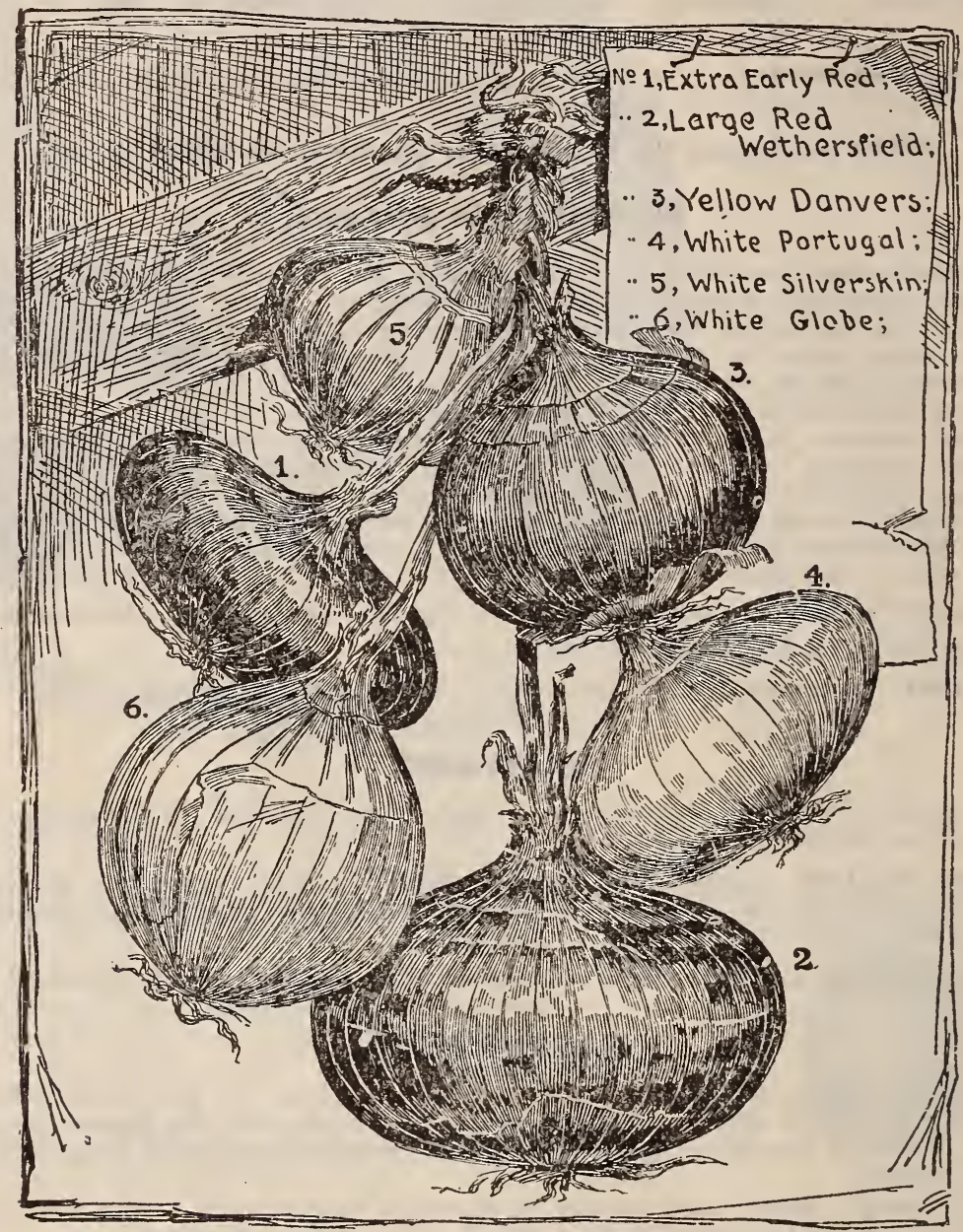

Extra Ear1y F1at Red. About ten days earlier than the Wethersfield, and somewhat smaller; close grained and heavy; mild flavor; excellent keeper. Pkt. 5c; 1 oz. 20c; $1 / 4$ lb. $50 \mathrm{c} ; 1$ ib. $\$ 1.50$.

Early Large Red Globe. Pkt. 5c; 1 oz. 20c; 1/4 1b. 40c; 1 lb. $\$ 1.25$.

Large Red Wethersfield. Round, good size and flavor; productive, keeps well, the standard red variety. Pkt. 5c; 1 oz. 20c; $1 / 41 \mathrm{~b} .50 \mathrm{c} ; 1 \mathrm{lb} . \$ 1.50$.

Giant Rocca. Light red, of immense size and globular form. It is of rapid grorith, and yields enormously. Flesh mild and sweet. Pkt. 5c; $1 \mathrm{oz} .20 \mathrm{c} ; 1 / 1 \mathrm{tb} .60 \mathrm{c} ; 1 \mathrm{lb} . \$ 1.75$.

Australian Brown. A new onion from Australia. Very early and a remarkable keeper. Handsome in color and very attractive in market. Pkt. 5c; $1 \mathrm{oz} .25 \mathrm{c} ; 1 / 4 \mathrm{lb} .65 \mathrm{c}$; $1 \mathrm{lb} . \$ 2.25$. 


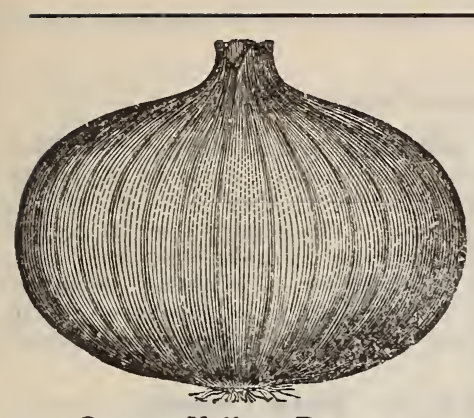

Oregon Yellow Danvers.

Oregon Yellow Danvers. This improved variety is pronounced by all onion growers who have tried it the very best strain of Yellow Danvers in cultivation. It is the earl est, largest in size, most perfect in shape, the largest cropper and the best keep. er, and as a market or table onion cannot be excelled. Our seed is grown from selected bulbs by one of the most experienced onion growers in Oregon. Pkt. 5c; 1 oz. $15 \mathrm{c} ; 1 / 4$ lb. $45 \mathrm{c} ; 1$ lb. $\$ 1.50$.

Ye110w Danvers. The old standard variety. Pkt. 5c; 1 oz. 15 c; $1 / 4$ 1b. 35 c; 1 lb. $\$ 1.25$.

Yellow Globe Danvers. Pkt. 5c; $1 \mathrm{cz} .15 \mathrm{c}$; $1 / 4 \mathrm{lb} .45 \mathrm{c} ; 1 \mathrm{lb} . \$ 1.50$.

Prize-Taker. An immense, globe-shaped, bright straw colored variety. Probably the largest globe variety known and in quality one of the best. Pkt. 5c; $1 \mathrm{oz} .20 \mathrm{c} ; 1 / 4 \mathrm{~b}$. $60 \mathrm{c} ; 1 \mathrm{lb} ; \$ 1.75$.

White Pear1. Very small early white silverskin onion. Pkt. 5c; 1 oz. 20c; 1/4 $1 \mathrm{~b}$. $65 \mathrm{c} ; 1$ 1). $\$ 2.00$.

Small Queen. A very nice silver-skinned Tripoli Onion, as remarkable for its keeping qualities as for its rapid growth. Very nild flavnred. If sown thickly, they produce small, very firm bulbs, good for pickling. Pkt. 5c; 1 oz. $25 \mathrm{c}$; 1/4 $1 \mathrm{~b}$. $75 \mathrm{c}$ : $11 \mathrm{lb} . \$ 2.50$.

Extra Early Barletta. A small onion of a pure paper-white color, very mild and delicate in flav.r. Valuable or table use and for pickling, Its extreme rapidity of growth will astonish every one who raises it for the first time. Pkt. 5c; $1 \mathrm{oz} .20 \mathrm{c} ; 1 / 4 \mathrm{lb} .60 \mathrm{c}$; 1 1b. $\$ 2.00$.

Pickling Onion. A special strain of a small white globe-shaped onion, particularly adapted to pickling purposes. Pkt. $5 \mathrm{c} ; 1$ oz. 20c; $1 / 4$ lb. $6 \overline{\mathrm{c}}$; $1 \mathrm{lb}$. $\$ 2.00$.

White G1 be. A handsome, globe-shaped variety. Flesh fine, rery white, rich and sweet. A good keeper. Pkt. 5c; 1 oz. $25 \mathrm{c} ; 1 / 41 \mathrm{~b} .75 \mathrm{c} ; 1$ b. $\$ 2.50$.

White Po+tugal, or Silver Skin. A good varietv for family use: skin and flesh pure white; mill fldvor and flat shape. The best white onion; also grown largely for sets. Pkt. 5c; 1 oz. 25c; $1 / 4$ lb 80 c; 1 lb. $\$ 2.50$.

Mammoth Silver King. An immense white onion of mild flavor. Very thick through, but incline 1 to be $f$ it rather than globe-shaped. Very shovy and at tractive in appedrauce. Sells well to the faucy trade. Pkt. 5c; 1 oz. 20:; 1/4 lb. 50c; 1 lb. $\$ 1.60$.

\section{ONION SETS.}

\section{If ordered by mail, add 10c. per $1 b$. for postage.}

Bottom Onion Sets. Grown from hlack see 1. Plant early in the spring in shallow drills twelve fe:t apart an 1 fo ir inche; a sart in the drills, and they will produce small green onions for the table in a short tim 2 . If sets are allowed to grow instead of being pulled for exrly table use, they will ma:e large onions mu:h earlier than they can be obtained from spring planting of seed. Either yellow, red or white. $1 \mathrm{lb} .15 \mathrm{c}$.

Top Onions. These do well either for a small bunch or for large onions. $1 \mathrm{lb} .15 \mathrm{c}$.

Multipliers. Grown for the green top; they do not make a first class large onion. $1 \mathrm{lb} .15 \mathrm{c}$.

Shallots. 1 1b. $20 \mathrm{c}$.

Chives. (German, Snittlach.) A delicate little plant belonging to the onion famil being perfectly hardy and coming quite early in the spring. $20 \mathrm{c}$ jer bunch, postpaid.

Garlic. The Garlic is the most pungent in taste and has the strongest odor of all the onion family. It is largely used in the south of Europe for fldvoring soups, stews, etc. The roots or bulb is composed of many small bulbs. Bulbs per 1b. 15c. 


\section{PARSLEY.}

Two ounces of seed to 100 yards of row.

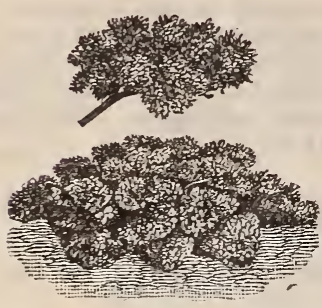

Used for garnishing and seasoning soups, meats, etc. Succeeds best in a mellow, rich so 1 . Sow thickly, early in A pril, in rows one foot apart and one half inch deep; thin out the plants to stand six inches apart in the rows. The seed is slow in germinating, taking from three to four weeks to make its appearance, and often failing to come up in dry weather. To hasten germination, soak the seed a few hours in warm water, or spruut 1n damp earth, and sow when they swell or burst. For winter use, protect in a frame.

Champion Moss-Curled, or Fern-Leaved. Leaves Moss Curled. bright green, beautifully curled and crested, like fern or moss; nothing better for garnishing could be desired. Pkt. $5 \mathrm{c} ; 1 \mathrm{oz} .10 \mathrm{c}$; $1 / 4$ 1b. 25 c; 11 b. 75 c.

Triple Curled. A fine, free-growing, but not large variety. The leares are bright green, and the plant is very hardy. Pkt. $5 \mathrm{c} ; 1 \mathrm{oz} .10 \mathrm{c}$; $1 / 4$ lb. 20c; 1 lb. 60c. 60c.

P1ain. Hardier than the curled. Pkt. $5 \mathrm{c} ; 1$ oz. 10c; 1/4 1b. 20c; $1 \mathrm{lb}$.

Hamburg, or Turnip-Rooted. A fleshy-rooted kind: the roots used for flavoring soups. Pkt. 5c; 1 oz. 10c; $1 / 4$ 1b. 25c; 1 lb. $75 \mathrm{c}$.

\section{PARSNIP.}

Three ounces of seed to 100 yards of row.

Sow as early in the spring as the weather will admit, in drills fifteen inches apart and one-half inch deep, in a rich, deep, well-manured soil, deeply dug. Cultivate similarly to carrots, and thin out to five inches apart in the rows. The roots improve by remaining in the ground over winter for spring. Valuable for feeding stock as well as for table use.

Large Sugar, or Hollow Crown. The best variety in cultivation; roots long, very smooth, white, tender, sugary and of excellent quality. Pkt. 5 c; 2 oz. 15 c; $1 / 4$ lb. 20 c; 1 lb. 50 c.

\section{PEPPER.}

Three ounces of seed to 100 yards of row,

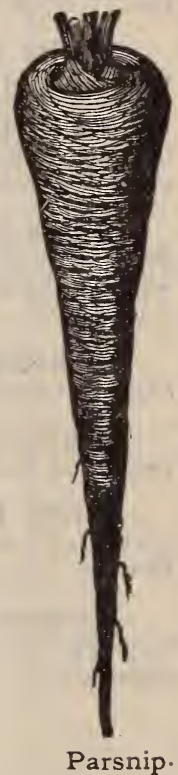

Sow in drills on a warm border, late in spring or commencement of summer, and thin them to stand sixteen to eighteen inches apart: or they may be sown early in the season in a hot-bed, or flower-pot, and transplanted.

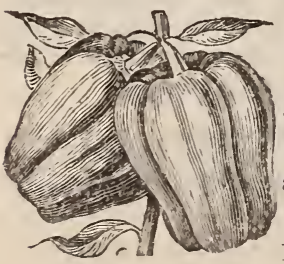

Large Bell or Bull-

Nose.

Large Bell, or Bul1-Nose. Early, glossy, red, very large and mild. Pkt. $5 \mathrm{c} ; 1 \mathrm{oz} .20 \mathrm{c} ; 1 / 4$ 1b. $60 \mathrm{c}$.

Golden Dawn. Of same shape and size as the Large Bell, but of more delicate flavor. Color, yellow. Pkt. 5c;1 oz. 20c; 1/ 1b. 60c.

Red Cayenne. The variety sold in the market; small and pungent. Pkt. 5c; 1 oz. 20c; $1 / 4$ lb. 60c.

Chili. Small: usedin pickles and pepper sauce. Pkt. 5c; 1 oz. 20 c; $1 / 4$ lb. 60 c.

Large Squash or Tomato-Shaped. Pods short, thick and ribbed at the point. They are very productive, fleshy and m ld, and excellent for pickling. Pkt. 5c; $1 \mathrm{oz} .20 \mathrm{c}$; 1/4 ib. 60c.

Ruby King. Beautiful bright red pods, four to six inches long; very mild. Pkt. 5c; 1 oz. 25c; 1/4 1b. 75 c. 


\section{PEAS.}

If ordered sent by mail, add 10 cents per $1 b$. for postage.

Three quarts of seed to 100 yards of row.

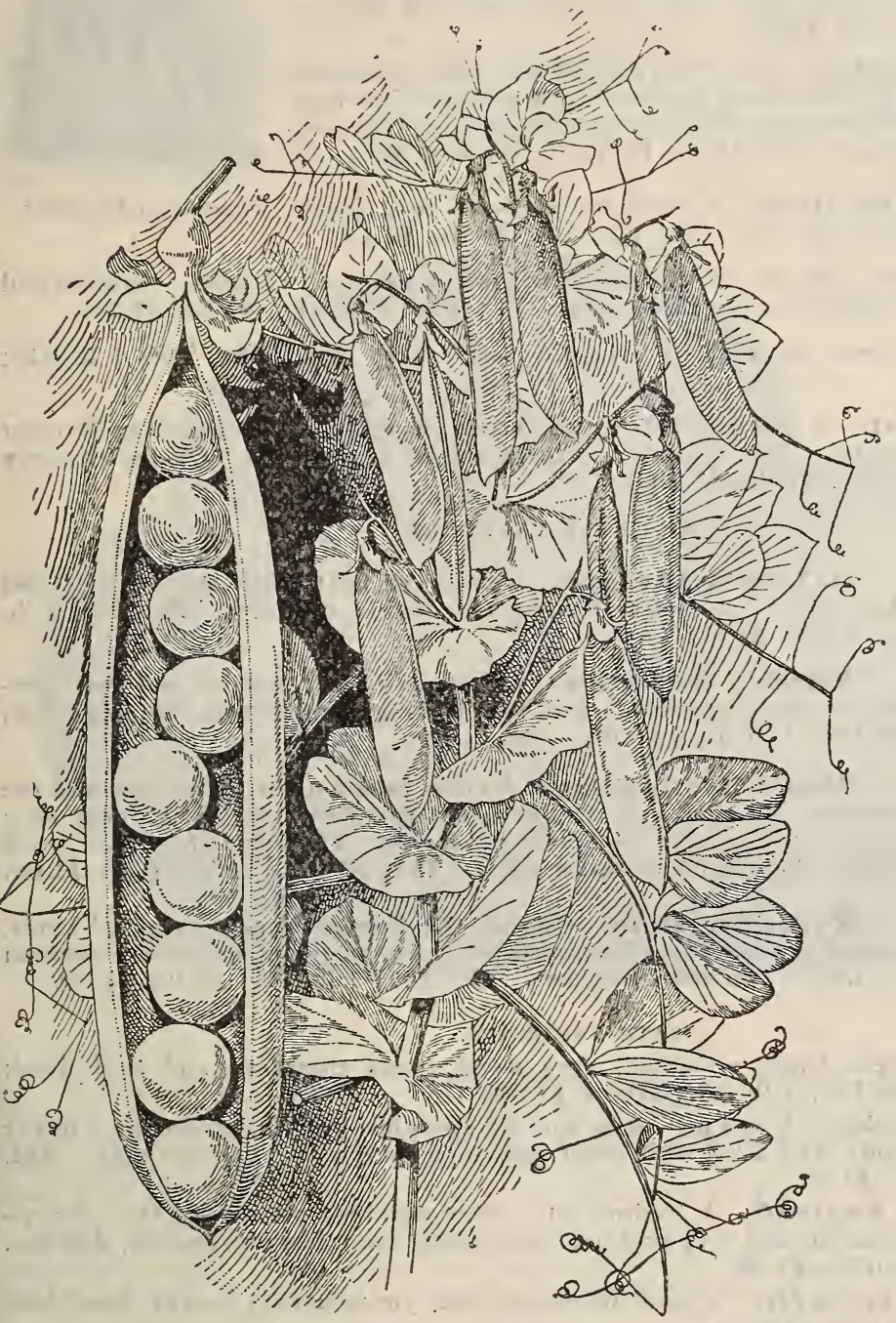

Peas ma ture earliest in a light, rich soil. For general crop, a rich deep loam is the best. They Lhrive better if the ground has been manured for a previous crop; but if the ground is poor and requires man u r ing, take w e 11-deconip osed manure. $W$ hen grown in gardens they are sown in double rows, six to eight inches apart, the tall ones requiring b r us h, which is stuck in between the rows. Commence sowing the extra early varieties as early as the ground can be worked in February or March, contivuing for a succession every two weeks until June, then discontinuing until the middle of August, $\mathrm{h}$ hen a good crop may be secured by sowing the extra early and early sorts for fall use. The wrinkled varieties are not as hardy as the small, hard sorts, and if planted e a r $1 \mathrm{y}$ should have a dyr soil, or they are liable to rot in the ground; they are, however, the sweet, est and best flavored varieties.

The dwarf varieties are best suited, from their dwarf habit, for small gardens, or for forcing, and can be planted in rows one foot apart.

\section{EARIY VARIETIES.}

* Nott's Excelsior. A splendid variety. Perhaps the most valuable of all the dwarf early wrinkled peas. Unsurpassed in earliness, yield and quality. It grows about one half as tall ayain as the American Wonder and is much more productive; of vigorous growth. Pkt. 10c; 1 lb. $15 \mathrm{c} ; 10$ lbs. $\$ 1.10$.

Alaska. Extra early, and very uniform in growth. The dark green color of the pods makes it verv desirahle, as it can be carried long distances without losing color, which qualitv, combiner with its earliness and uniformity of ripening, makes it one of the most desirahle extra early peas for market gardening; height, two feet. Pkt. 10c; $1 \mathrm{lb}$. 15 c; 10 lbs. $\$ 1.00$.

- Varieties marked $(*)$ are wrinkled. 
First and Best. Very early. One of the very best for market gardeners, as the whole crop ripens in a few days, so that th: ground may be cleared and another crop planted. About forty-five days is the average from planting until the crop is ready for market. Pkt. 5c; 1 lb. 15 c; 10 lbs. $\$ 1.00$.

*American Wonder. One of the earliest and most productive dwarf wrinkled peas in cultivation; requires no brush and is of most exquisite flavor. The vines grow eight or more inches high, according to the soil and season. $\mathrm{Y}$ kt. $10 \mathrm{c} ; 1 \mathrm{lb}, 15 \mathrm{c} ; 10 \mathrm{lbs} . \$ 1.00$.

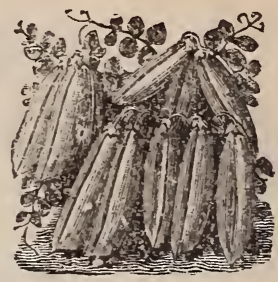

*McLean's Little Gem. A very early dwarf pea; green, American Wonder. wrinkled and very delicious. Plst. 10c; 1 lb. $15 \mathrm{c} ; 10 \mathrm{lbs} . \$ 1.10$.

* Premium Gem. One of the earliest dwarf green wrinkled varieties. Prolific and of excellent quality. Similar to the Little Gem. Pkt. 10c; 1 b. $15 \mathrm{c} ; 10$ lbs. $\$ 1.10$.

*Exonian. A new, extra early wrinkled sort. Very fine. Pkt. 10c; $1 \mathrm{lb} .15 \mathrm{c}$; 10 lbs. $\$ 1.10$.

* William Hurst. A new dwarf wrinkled variety, as early as the American Wonder and much more productive. The whole crop ripens almost at one time. Quality the very best. Ykt. 10c; 1 lb. $15 \mathrm{c} ; 10 \mathrm{lbs} . \$ 1.10$.

\section{SECOND EARLY VARIETIES.}

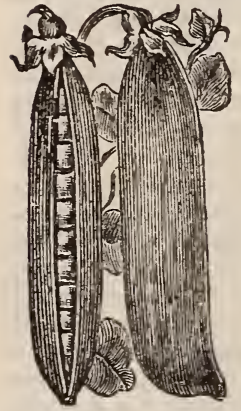

Bliss's Everbearing.

* Telephone. height, four feet.

* Stratagem. Select. Vines not large but of vigorous growth, producing a heavy crop; beautiful long pods, well filled with large peas of good quality; two feet high. $\mathrm{Pkt}$. $10 \mathrm{c} ; 1$ lb. $15 \mathrm{c} ; 10$ lbs $\$ 1.00$.

* Champion of England. A leading late, sweet wrinkled pea among the tall varieties. Vines large, luxuriant and very prolific. For family use it has no superior; five feet. Pkt. 10c; 1 lb. 15c; 10 lbs. $\$ 1.00$.

Black-Eyed Marrowfat. A good Marrowfat pea; yields heavy; height three feet. Pkt. 10c; 1 lb. 15c; 10 lbs. 75 c.

\section{EDIBLE PODDED VARIETIES.}

Dwarf Sugar Edible Podded-Gray Seeded. One of the best edible podded kinds. Early; peas large, tender and very sweet. Pkt. 10c; $11 \mathrm{~b} .15 \mathrm{c}$.

Meling Sugar. It grows to the height of five feet, bears a profusion of large, broad pods, which are generally found in pairs, and which are so brittle that thes snap uithout any string. It should be used in much the same way as a Wax Bean. The pods, when cooked, are very sweet and tender. Pkt. 10c; $1 \mathrm{lb} .20 \mathrm{c}$.

FIELD VARIETIES.

Small White. Standard sort. $1 \mathrm{lb} .10 \mathrm{c} ; 100 \mathrm{lbs}$. market price.

Blue Prussian. Blue Pea. $1 \mathrm{lb} .10 \mathrm{c} ; 100 \mathrm{lbs}$ market price.

Swiss. Three-cornered white pea. Good for cooking. 1 lb. 10c; $10 \mathrm{lbs} .60 \mathrm{c}$. 


\section{POTATO.}

The soil best suited to the potato is that of a rich sandy loam, but it seems to thrive in almost any soil or climate, not requiring heavily-manured ground to insure a crop. In heavy soils and if heavily manured, it is more liable to disease than in naturally good, light soil. Plant as early in the spring as the ground can be worked, and, if you wish a healthy, vigorous growth and a crop free from rot, in hills or rows three feet apart and one foot apart in the rows. In warm, light soil, cover about four inches, and in cold wet ground, three inches deep. Cultivate to keep down the weeds, and draw the earth to the plants as they advance in growth.

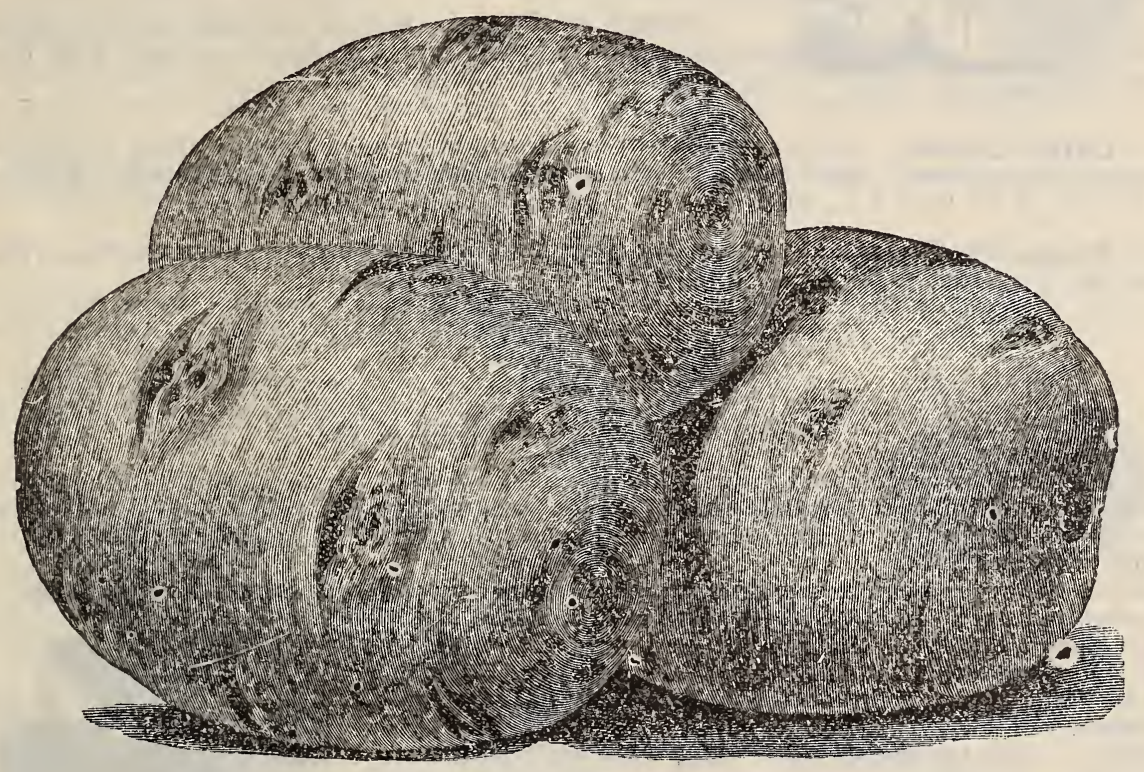

Briggs Extra Early-Originated in Oregon. Very early. A seedling from Early R'se. Large, smooth, fine quality: flesh white. Yields an immense crop. The Brigys Extra Eurly has been thorouyhly tested for several seasons, and is undoubtedly a better potato for Oregon than most of the new varieties brought here from the east. By mail, 1 1b. 20c; 3 lbs. 50c; by express or freight, 1 bu. $\$ 1.50$.

The Bovee. A recent introduction which is unsurpassed in earliness, yield and goud quality. The tubers are remarkably even in size. A very heavy cropper. By mail, 1 lb. 35 c; 3 lbs. 90c : by express or freight, 10 bs. $\$ 1.75 ; 1 / 2$ bu. $\$ 1.50$.

Early Sunrise, Early Beauty of Hebron, and Early Rose. Either, by mail, 1 lb. 1 . ic; by freight, per bu. $\$ 1.00$.

Peerless. Large size, very produrtive, good quality, white skin and flesh. Excellent for general crop. By mail, 1 1b. 20c; by express or freight, $1 \mathrm{bu} . \$ 1.25$.

Freeman. A potato of great merit. Eyes rery small. A large cropper. By mail, 1 lb. 20 c ; 3 lbs. 40 c; by express or freight, 1 bu. $\$ 1.30$.

Carman, No. r. A very fine second early variety. By mail, 1 1b. 20c; 3 1bs. 40c; by express or freigtt, 1 bu. $\$ 1.20$.

Rural New Yorker No. 2. A splendid medium early potato; eyes very few and shallow: skin and fesh pure white; splendid table variety and immense yielder. By mail, $1 \mathrm{lb} .20 \mathrm{c}$; by freight, 1 bu. $\$ 1.20$. 


\section{PUMPKIN,}

Ground should be rich. Leave only one or two vines in a hill. When the soil and climate are favorable, they are a profitable crop for feeding purposes.

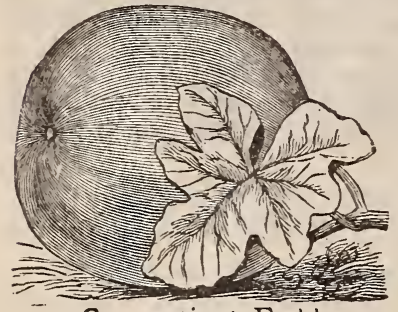

Connecticut Field.

Connecticut Field, or Large Yellow. A good pumpkin. Grown principally for feeding stock. Pkt. 5c; $1 \mathrm{oz} .10 \mathrm{c} ; 1 / 4 \mathrm{lb} .15 \mathrm{c} ; 1 \mathrm{lb} .35 \mathrm{c}$.

Cushaw, or Crookneck. Large, productive, fleshy and excellent. Color, light cream. Pkt. 5c; 1 oz. 10c; $1 / 41 \mathrm{~b} .20 \mathrm{c} ; 1 \mathrm{lb} .55 \mathrm{c}$.

Sweet, or Sugar. Round, not large, but very sweet; an excellent table variety. Pkt. 5c; 1 oz. 10c; 1/4 1b. 20c; $1 \mathrm{lb} .60 \mathrm{c}$.

Large Cheese. Large oval shaped, mottled light green and yellow: flesh very thick, sweet and nutritious. More ne.trly related to the squash than the Large Yellow. Pkt. 5c; 1 oz. $10 \mathrm{c} ; 1 / 4$ lb. 20c; 1 lb. 60 s.

Mammoth Toxrs. A productive French variety which grows to an enormous size. Pkt. 5c; 1 oz. 10c; 1/4 lb. 25c; 1 lb. 75c.

\section{RADISH.}

Six ounces of seed to 100 yards of row.

Radishes thrive the best in a light, rich, mellow soil. Heavy or clay soils not only delay their growth, but produce a crop much inferior in appearance and fldvor. Sow the early varieties for very early use, in sheltered borders as soon as the ground can be worked, in well-manured, deep$1 y$-dug and finely-raked soil. If not well stimulated into a rapid growth, they become fibrous and tough. Sow in drills ten inches apart and thin to two inches in the rows, and sow at intervals of two or three weeks until September for a succession. The winter varieties should be sown in July and August. Like the turnip, they make their best growth in the autumn, and renıin crisp all winter. Before using, put in cold water, which adds to their freshness.

Scarlet Turnip White Tipped. Similar to the Scarlet Turnip-rooted, only that the under side of the bulb and tap-root is white. Pkt. $5 \mathrm{c} ; 1 \mathrm{oz} .10 \mathrm{c} ; 1 / 4 \mathrm{lb} .20 \mathrm{c} ; 1 \mathrm{lb}$. $60 \mathrm{c}$.

Early Scarlet Turnip. A small, round, scarlet, turnip-shaped, small-topped variety, of quick giowth, mild and crisp when young. Pkt. 5c; 1 oz. 10c; 1/4 1b. 20c; 1 lb. 50c.

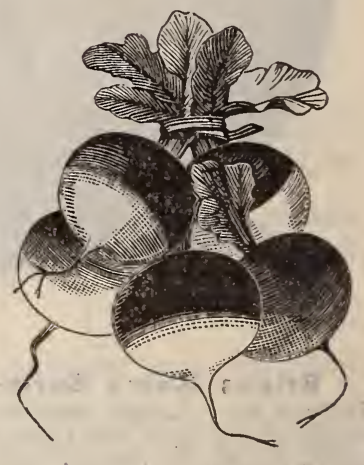

Scarlet Turnip, White. Tipped.

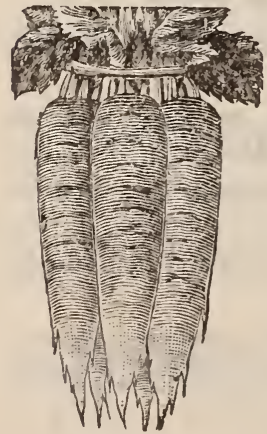

Improved Chartier.

Early White Turnip. Similar to Scarlet Turnip, except in color. Pkt. 5c; 1 oz. 10c; 1// 1b. 20c; 1 lb. 60c.

Golden G:obe, or Summer. Shape, globular; color amber; flavor, mild: keeping long in eating condition. Twenty-five days to maturity. Pkt. 5c; 1 oz. 10c; 1/4 1b. 20c; i 1b. 65c.

Early Scarlet Olive Shape 1. An excellent variety of rapid growth; skin, thin; flesh, rose-tinted and very tender. Pkt. 5c; $1 \mathrm{oz} .10 \mathrm{c} ; 1 / 4 \mathrm{lb} .20 \mathrm{c} ; 1 \mathrm{lb} .55 \mathrm{c}$.

Half-Long Deep Scarlet. A handsome variety resembling somewhat the Ulive-Shaped, but of a dreper scarlet. Good for forcing. Pkt. 5c; 1 oz. 10c; 1/4 1b. 20c; 1 lb. 60c.

Improved Chartier. Of rapid growth. Soon ready for the table, re "aining crisp and tender until fully grown. Color, scarlet above, shading into white at the tip. Flesh white and mild flavored. Pkt. 5c; 1 oz. 10c; 1/4 1b. 20c; 1 1b. 60c. 


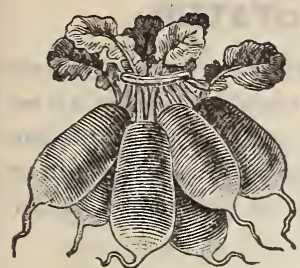

French Breakfast.

French Breakfast. Oblong shaped, rapid growth, very mild and tender; of a beautiful scarlet tipped with white. Pkt. 5c; 1 oz. $10 \mathrm{c} ; 1 / 4$ 1b. 20c; 1 lb. 60 c.

Early Long Scarlet Short-Top. The standard family and market gardepers' variety; long, bright scarlet, with small top. Pkt. 5c; 1 oz. 10c; 1/4 lb. 20c; 1 lb. 50c.

Early Long, Brightest Scarlet. A long radish. Color, strikingly bight scarlet, general appearance very attractive. Extra early: flesh very tender. Valuable for forcung on open ground. Pkt. 5c; 1 oz. 10c; 1/4 1b. 20c; 1 lb. 60c.

Lady Finger, or White Vienna. Crisp and tender in summer. Pkt. $5 c ; 1 \mathrm{oz}$. 10 c; $1 / 4$ lb. $25 \mathrm{c} ; 1$ lb. 60 c.

White Stuttgart. Root large, often four inches in diameter, top shaped, skin white. Flesh white and crisp, and not becoming strong or pithy until very late, so that those not used as a summer radish can be stortd for winter use. Pkt. 5c; 1 oz. 10c; 1/ 1b. 25c; $1 \mathrm{lb} .75 \mathrm{c}$.

White Strasburg. A very desirable summer variety. Both flesh and skin pure white. Pkt. 5c; 1 oz. 10c; 1/4 1b. 20c; 1 lb. 60c.

\section{WINTER VARIETIES.}

China Rose Winter. One of the best winter varieties. A general favorite. Flesh white, firm and of superior quality. Pkt. $5 \mathrm{c} ; 1$ oz. $10 \mathrm{c} ; 1 / 4 \mathrm{lb} .25 \mathrm{c} ; 1 \mathrm{lb} .75 \mathrm{c}$.

Round Black Spanish. A fine globe-shaped winter radish, very popular with the Germans, and known as Rettig; goud quality and flavor. Pkt. 5c; $1 \mathrm{oz} .10 \mathrm{c} ; 1 / 41 \mathrm{~b} .20 \mathrm{c} ; 1 \mathrm{lb}$. 60c;

Long Black Spanish. A large winter variety, one of the hardiest, with dark green leaves; firm in lexture, keeping until spring. Pkt. 5c; 1 oz. 10c; 1// lb 20c; 1 lb. 60c.

Californiz Mammoth White. A winter variety, white fleshed, firm and of excellent quality. It is the largest radish grown. Called by some the Mammoth Kussian. Ykt. $5 \mathrm{c} ; 1 \mathrm{oz} .10 \mathrm{c} ; 1^{\prime} 4^{\prime} 1 \mathrm{~b}$. 25c: $1 \mathrm{lb} .75 \mathrm{c}$.

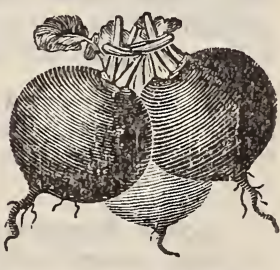

Round Black Spanish.

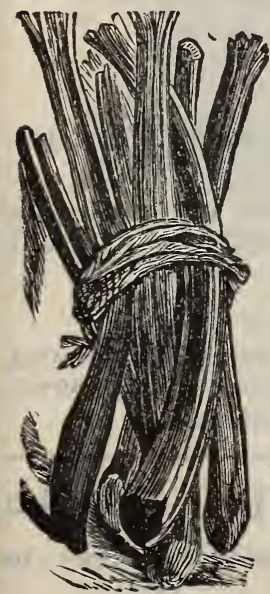

Victoria.

\section{RHUBARB, OR PIE PLANT.}

Four ounces of seed to 100 yards of row.

Cultivated in the garden for pies and sauce. No market garaener or family should be without it. May be propagated from seeds, but is usually grown from roots. The soil should be deep and richthe richer the soil the better. $\$ 1.35$.

Linaeus. The earliest. Pkt. 6c; 1 oz. 15c; $1 / 41 \mathrm{~b} .45 \mathrm{c} ; 1 \mathrm{lb}$.

Victoria. Very large; finest cooking variety. Pkt. $5 \mathrm{c} ; 1 \mathrm{oz}$ $15 \mathrm{c} ; 1 / 4$ lb. $45 \mathrm{c} ; 11 \mathrm{~b} . \$ 1.35$.

Giant. One of the most vigorous and productive varieties known. Pkt. 5c; 1 oz. 15c; 2/4 lb. 45c; 1 lb. \$1.35.

\section{For Rhubarb Roots see Garden Roots.}

\section{SUNFLOWER.}

The sunflower is now in larger demand than erer before. Its uses are raried. The leaves are good for stock, the seed for poultry and the manufacture of oil, and the stalks and heads for fuel. It has also proved itself a powerful and valuable absorbent of miasma. It is hardy and easily grown. Cultivate the same as corn. The double varieties are cultivated as flowers. See Flower List.

Mammoth Russian. The largest and most productive variety. $1 / 41 \mathrm{~b}, 10 \mathrm{c} ; 1 \mathrm{lb}$. 20c. By express or freight, purchaser paying charges, $1 \mathrm{lb} .10 \mathrm{c} ; 10 \mathrm{lbs}$. $70 \mathrm{c}$. 


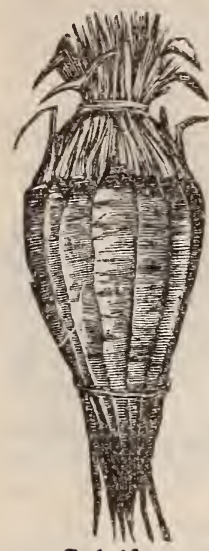

Salsify.

\section{SALSIFY, OR VECETABLE OYSTER.}

Cultivate the same as carro's and parsnips. It is hard $r$, can remain in the ground a 1 winter for earlv spring use, but should be taken up before it $s$ arts to grow. Succeeds best in a light. well enrirhed mellow soil, dug two spades deep. Sow early in the spring in drills fifteen inches apart, in rows one inch deep. Thin out to six inches apart, keeping clear of weeds.

Lnng White. The favorite market variety. Pkt. $5 \mathrm{c} ; 1 \mathrm{oz} .10 \mathrm{c}$; 1/4 1b. 35c; 1 lb. \$1.10.

Mammoth Sandwich I-1and. A very fine variety: growing nearly twice the size of the old sort. This is taking the lead in the market and we recommend its use.

\section{SPINACH.}

Four ounces of Seed to 100 yards of row.

This is an important gir.leners' crop, of easy culture. For spring and summer use, sow either broadcast or in drills one foot apart and oue inch deep, as tarly as the grourd can be worked, and every tno nerks for a succession. As it grows, thin out for use, keeping it clear from weeds For winter and exrly snring use, sow in sepemtser. in well manured ground. Cover with straw on tle al proach of selere cild nether 1 he grould cannot be tou rich: the stronger the ground the more delicate and succulent will be the leaves.

Savoy Leaved. A very earlv variety which goes to seed ersily but is hardy and mav be planed for early spring use. Pkt. 5c; $1 \mathrm{oz} .10 \mathrm{c} ; 1 / 4 \mathrm{lb} .15 \mathrm{c}$; 11 b. 50c.

Long Standing. An imnroved variety, slow in going to seet, and perhaps the best for general use. Pkt. 5c: 1 oz. $10 \mathrm{c} ; 1 / 4$ lb. $15 \mathrm{c} ; 1 \mathrm{lb} 50 \mathrm{c}$.

Round Summer. The leaves of this variety are unusutlly thick, fle-hy and tender. It is also hardy and mav be sown as somn as the ground can be thoroughly prepared. Pkt 5c; 1 oz. 10c; $1 / 4$ lb. 15c; 1 lb. 50c.

Prickly Seed, or Fall. The hardiest variety having smaller leaves but not so prodactive as the Kound Leaved. Pkt. 5c; 1 oz. 10c; 1/4 1b. 15c; 1 lb. 50c.

Monstrous Vi-ofiy. This variety produc's the largest leaves of any, yielding an enormons crop. Excellent for the fanily or market garden. Pkt. $5 \mathrm{c} ; 1 \mathrm{oz} .15 \mathrm{c} ; 1 / 4 \mathrm{lb}$ $15 \mathrm{c} ; 1$ lb. 50 .

\section{SUGAR-CANE.}

Cultivate the same as corn. It is surprisiug that more attention is not paid to growing sugar-cane, as it affords one of the most prolific and protitable crops fur stock feeding known,

Early Ambre. Early and rapid growth. I kt. 5c; 1/4 1b. 10c; 1 lb. 25c.

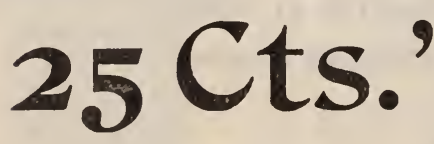

\section{Worth of Seeds EXTRA will be} allowed on each ONE DOLLAR sent for Seeds in PACKETS and OUNCES.

Thus any one sending us $\$ 1.00$ can select seeds in PACKETS and OUNCES to the vulue of \$1.25; fint \$2.00 seeds in PACKETS and OUNCES to the ralue of \$2.50; for $\$ 3.00$, seeds in PACKETS and OUNCES to the value of \$3.75.

This premium does not apply where any other prewium is taken.

\section{OUR SEEDS ARE THE BEST AND OUR PRICES ARE LOW.}




\section{SQUASH.}

If ordered by express or freight, deduct 10c. trom single-pound price.

Three ounces of seed to 100 yards of row.

A very tender plant, of rapid and luxuriant growth; will not stand any frosts or cold nights and should be planted in a rich, warm light soil, after the weather has becone settled and warm. Plant in well-manured hills in the same mauner as cucumbers and melons, the bush varieties three or fuur feet apart each way, and the running varieties fiom six to eight feet apart.

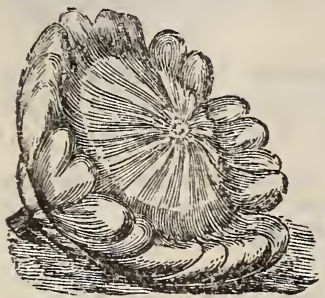

Early White Scallop Bush. The earliest variety for market or shipping. It griws to a large size, scalloperl like a patti-pan, and bearing an abundant crop. Pkt. 5c;1 oz. 10c; $1 / 4$ lb. $20 \mathrm{c} ; 1 \mathrm{lb}$. $60 \mathrm{c}$.

Mammoth White Bush, Scalloped. An improvement on the precerling in foint of size, being iwrlve to tifeen incher acros:; rery productive and uniform in growth. Pkt. 5c, 1 oz. $10 \mathrm{c} ; 1 / 4 \mathrm{lb} .25 \mathrm{c} ; 1 \mathrm{lh}$. $6.3 \mathrm{c}$.

Ear'y Summer C-ook-Neck. A very

White Scallop Bush. rich, nell-known summer vari ty. Pkt. 5c; $1 \mathrm{oz} .10 \mathrm{c} ; 1 / 4 \mathrm{lb} .25 \mathrm{c} ; 1 \mathrm{lb} .60 \mathrm{c}$.

Mammoth Summer Crook-Neck. Twice the size of the ordinary Summer Crook-Neck; also earlier and more warty; a decided advance on the old kind. Pkt. $5 \mathrm{c} ; 1 \mathrm{oz} .10 \mathrm{c}$; $1 / 4 \mathrm{lb}$. 25c: $1 \mathrm{lb} .65 \mathrm{c}$.

\section{IATE VARIETIES.}

Boston Marrow. A rich, tender variety for fall and winter use. Ykt. $5 \mathrm{c} ; 1 \mathrm{oz} .10 \mathrm{c} ; 1 / 4$ 1b. 20c; $1 \mathrm{lb} .60 \mathrm{c}$.

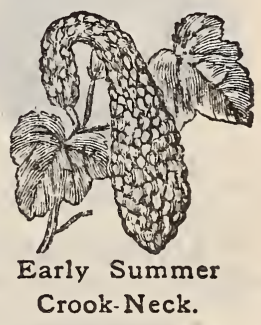

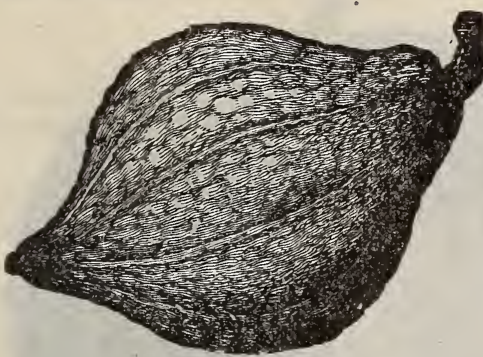

Hubbard Squash.

Orange Marrow. An improved Boston Marow. Qute distinct, very early, and of mo-t delicate Havor: suitable for fall and winter. Pkt. 5c; 1 oz. $10 \mathrm{c} ; 1 / 4 \mathrm{lb} .20 \mathrm{c} ; 1 \mathrm{lb}$. $60 \mathrm{c}$.

Hubbard. The standard winter squash; best known: Pkt. 5c; 1 oz. 10c: 1/4 lb. 20c; $11 \mathrm{~b}$. 60c.

Marb ehead. A variety about as large as the Hubhard, having a verv hard rind, of a bluish tint; flesh deep orange colored; very dry and su eet. It is also one of the hest keepers. Pkt. 5c; $1 \mathrm{oz} .10 \mathrm{c}$; $1 / 4$ 1b. $25 \mathrm{c}$ : $1 \mathrm{lb}$. $75 \mathrm{c}$.

Mammoth Chili. This is the largest variety hundred pounds. Pkt. $5 \mathrm{c} ; 1$ oz. 10c; 1/4 1b. 25c; $1 \mathrm{lb} .65 \mathrm{c}$.

Essex Hybrid, or American Turban. A good fall and winter variety. Pkt. 5c; 1 oz. 10c; 1/4 lb. 20c; $1 \mathrm{lb} .60 \mathrm{c}$.

Fordhook. One of the best winter squashes; fine quality. Pkt. 5c; 1 oz. 10c; $1 / 4$ lb. 20c; 1 1b. 60c.

The Faxon. One of the newer good varieties. The flesh is a deep orange-yellow. Sweet and dry: a good winter variety. Pkt. 5c; 1 oz. 10c; 1/4 1b. 20c; 1 lb. 60c.

English Vegetable Marrow. White flesh: outside yellow: grous ahout nine inches long; ribbed. Pkt. 5c; 1 oz. 10c; $1 / 4$ 1b. 25c; 1 lb. 75 c.

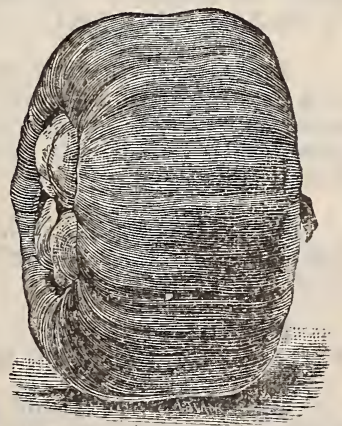

American Turban. 


\section{TOMATO.}

One ounce of seed to 100 yards of row.

The value of the tomato as a table vegetable can hardly be over-estimated. For early crop, sow as soon as desirell in hot-bels. When two inches high, transplant in the beds to four or five inches aptrt edch way, to give the plants roon and nake them bushy, always keeping them well aired. If they crowil eich otiser before time to transplant, rootpruae by drawiny a sharp knife deeply between the plants. When danger of frost is past, trausplant to rich. loose soil, keeping well watered and cultivated. For later crop, tliey mav be sown in coil 1 frames or open ground, and transplanterl when four to six inches high. If posible, support the vines. Thus treated, they will continue in bearing much longer, and the fruit be greatly improved.

Atlantic Prize, Extra Early. An early variety, of good size and smooth surface. Many objectionst, the u-ual early kinds, such as under size and deep'y corrugated, rough skin, are overcome in this tomato. $4 \mathrm{kt} .5 \mathrm{c} ; 1 \mathrm{oz} .20 \mathrm{i} ; 1 / 4 \mathrm{lb} .60 \mathrm{c} ; 1 \mathrm{~b} . \$ 200$.

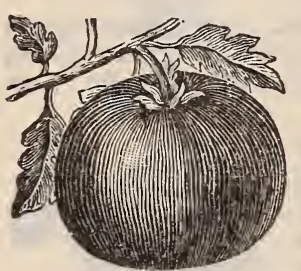

Livingston's Perfection.

Early Michigan. A very smooth, perfectly shaped tomato, solid aud nithout core. A strong grower and heavy cropper. Early. Pkt. 5c; 1 oz. 20c; $1 / 4$ lb. 60c; 1 lb. $\$ 2.00$.

Acme. One of the earliest; is of a strong and vigorous growth, very productive; fruit of a medium size. Pkt. $5 \mathrm{c} ; 1 \mathrm{oz}$. $20 \mathrm{c} ; 1 / 4$ lb. $60 \mathrm{c} ; 1 \mathrm{lb} . \$ 2.00$.

Livingston's Perfection. One of the best medium early kinds; round, unformly smooth; vines very productive; fruit deep scarlet, firm, and of excellent quality. Vines continue long in bearing. Sow this variety for main crop. Pkt. $5 \mathrm{c} ; 1$ oz. 20c; $1 / 41 \mathrm{~b}$. $50 \mathrm{c} ; 1 \mathrm{lb} . \$ 1.75$.

Iivingston's Beauty. For shipping and early market it cannot be excelled on account of solidity and toughness of skin. Pkt. 5c; 1 oz. 20c; $1 / 41 \mathrm{~b} .60 \mathrm{c} ; 1 \mathrm{lb} . \$ 2.00$.

Livingston's Favorite. One cf the best for tenerdl crop; vines vigorous, continuing in bearing all season; fruit very large, uniformly sulooth, firm, without hard core: ripens medium early; holds its size well till frost: is very fleshy, with few seeds. Pkt. 5c; 1 oz. 20c; 1/4 1b. 60c; 1 lb. $\$ 2.00$.

Trophy. Very large and smooth; late. Pkt. 5c; 1 oz. 20c; $1 / 4$ 1b. 65c; 1 lb. $\$ 2.00$.

Royal Red. Vines stronger and more vigorous than the Favorite; fruit larger, brighter, deeper red and fully as good in quality. l'kt. 5c; 1 oz. 20c; $1 / 4$ lb. 50c; 1 lb. $\$ 2.00$.

Ignotum. A very large tomato of fine grain, good flavor and without hard core. Fruit red. smooth and solid. Very productive. Pkt. 5c; 1 oz. 20c; $1 / 4 \mathrm{lb}$. 60c; 1 lb. $\$ 2.00$.

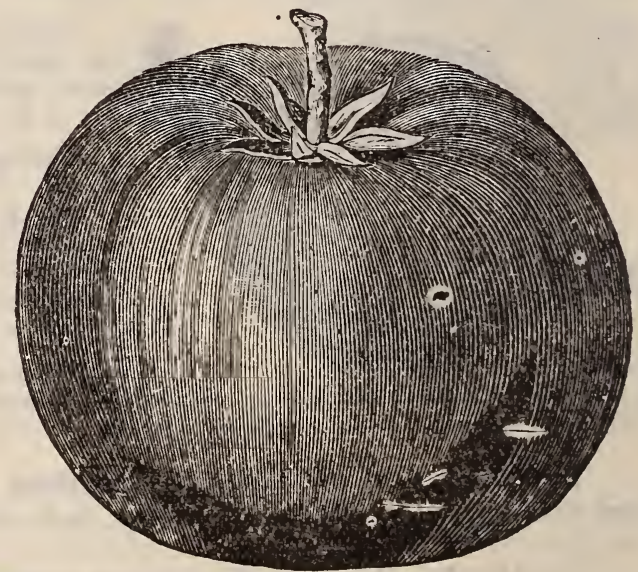

Livingston's Favoirte.

New Imperial. This fine new tomato is very early, large, quite fleshy and free from anv harl core. The fruits are red, smooth and of fine form. Pkt. 5c; 1 oz. 25c; 1/4 lb. 75 c; 1 lb. $\$ 2.50$.

Fordhook First. A very early, large, smooth tomato of good form and yield. Pkt. 5c; 1 oz. 20c; $1 / 4$ lb. 60c; 1 lb. $\$ 2.00$.

Optimus. A second early kind; uniform in sire; color bright red; smooth and handcome. One of the very best for this climate. Pkt. 5c; 1 oz. 20c; $1 / 41 \mathrm{~b} .65 \mathrm{c} ; 1 \mathrm{lb} . \$ 2.00$.

Dwarf Champion. Quite distinct in foliage and hahit of growth, being compact and upright. fruits early, and resembles the Acme in apearance. Pkt. $5: ; 10 z .20 \mathrm{c} ; 1 / 1 \mathrm{lb}$. 60 c; 1 lb. $\$ 2.00$. 


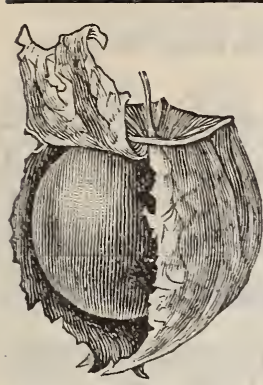

Ground Cherry.

Golden Queen. Very hamliome: flesh, yellow, rich, and of superior quality. Pkt. 5c; $1 \mathrm{oz}, 20$; 1/4 1b. 60; $1 \mathrm{lb} . \$ 2.00$.

Red Cherry. Fruit about an inch in diameter; grows in bunches; used for pickles. $\mathrm{Pkt} 5 \mathrm{c} ; 1$ oz. 30c; 1/4 lb. $85 \mathrm{c} ; 1 \mathrm{lb}$. $\$ 2.75$.

Pear-Shaped. For pickles. Pkt. 5c; 1 oz. 30c; 1/4 lb. $85 \mathrm{c}$; $1 \mathrm{lb} . \$ 2.75$.

Husk Tomato, or Ground Cherry. Fine for sauce, preserves and for eating fresh. Pkt. $5 \mathrm{c} ; 1$ oz. 30c; 1/4 1b. 85c; 1 lb. $\$ 2.75$.

For Plants, see under heading Vegetable Plants.

\section{TOBACCO.}

Connecticut Seed Leaf. Pkt. 5c; 1 oz. 20c; 1/4 1b. 60c.

Havana. Pkt. 5c; 1 oz. 35c; 1/4 lb. $\$ 1.00$.

\section{TURNIP.}

Three ounces of seed to 100 yards of row.

The turnip delights in a light, rich, sandy loam which has been well manured. For earlv use, sow the early varietirs as soon as the ground opens in the spring, in irills from twelve to fifteen inches apart. Thin out to from six to nine inches in the lows. Or, if sown brnarlcasi, they will produce a fine crop. but not as large as if sown in dills. Keep the ground nell stirred and clear of weeds. For a succession, continue to sow tvery two weeks until June, then discontinne until the middle of July. For a fall and winter crop, sow on potato ground, making your last sowing not later than the first of september.

WHITE FLESHED KINDS.

Extra Early Purple-Top Milan. The earliest varietv of turnip. Top small, erect, strap-leared; bulb very that, a deep purple above, white underneath: fesh white, firm and delicate; an excellent keeper. Pkt. $5 \mathrm{c} ; 1 \mathrm{oz} .10 \mathrm{c} ; 1 / 1 / 4 \mathrm{lb} .30 \mathrm{c} ; 1 \mathrm{lb} .90 \mathrm{c}$.

Extra Ear1y White Milan. As early as the above and a beautiful pure white. Pkt. 5c; 1 oz. 10c; $1 / 4$ lb. 30c; 1 1b. $\$ 1.00$.

Early Red-Top Strap-Leaved. One of the best; flat and good size. Pkt. 5c; 1 oz.10c; 1/4 1b 20c; $11 \mathrm{lb}$. 50c.

Early White Flat Dutch. A learing whitefleshed variety and one of the best, either for the family, market garden, or field crop. It is of medium size and produces a large crop. The flesh is firm but tender, and of a superior, rich, buttery flavor. A good keeper. Pkt. 5c; 1 oz. $10 \mathrm{c} ; 1 / 4$ ib. 20c; 1 lb. $50 \mathrm{c}$.

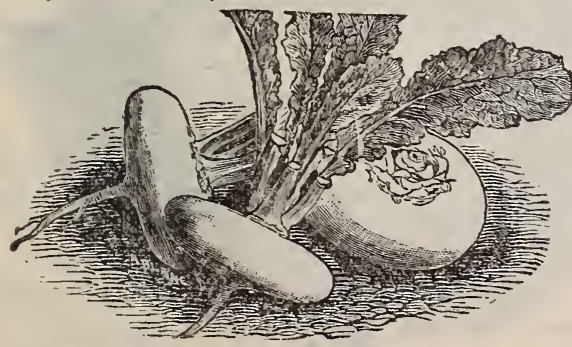

Early Flat White Dutch.

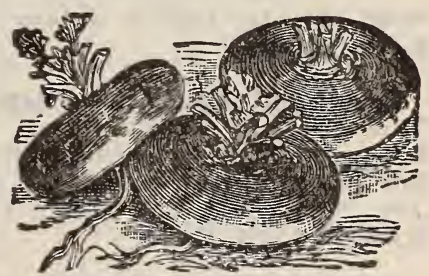

Early Red-Top StrapLeaved.

White Egg. An entirely distinct variety. It belungs to the class of yuick-growing fall turuips. Of extra fine flavor aud texture. Pkt. 5c; 1 oz. 10 ; ; 1/4 lb. 20c; 1 1b. 50c.

Purple Top White Globe. A large globe. shaper variely, purple above ground. It is handsome and of excellent quality. Pkt. 5c; $1 \mathrm{oz} .10 \mathrm{c} ; 1 / \mathrm{l}$ lb. 20c; $1 \mathrm{lb} .50 \mathrm{c}$.

White Norfolk. A large-growing, round, flat shaped varietr; coarse-grained and sweet. One of the best early for feeding stock. Pkt. $5 \mathrm{c} ; 1 \mathrm{oz} .10 \mathrm{~s} ; 1 / 4$ lb. 20c; 1 lb. 50c.

Pomeranian White Globe. This is one of the most productive kinds, and in good, rich :o 1 roots will frequentlv grow to twelve pounds in weight. It is of perfert globe shape: skin white and smooth, leaves dark green and of strong growth. Pkt. $5 c ; 10 z .10$ c; $1 / 4$ lb. $20 ; 1$ lb. 50 . 
Seven Top. A viriety ciltivated for its large tops which are excellent for greens. Pkt. 5c; 1 oz. 10c; 1// 1b. 20c; 1 lb. 60c.

Cow Corn, or Iong White. A distinct variety, having a long, slightly curved roo!. someuhat resembling a carrot. It is white, with a green tinge nt ar the top. grouirg partly abive the ground; fle h tender, sweet and of fine quality. Can be sown early for fall and winter use. Pkt. 5c; 1 oz. 10c; 1/4 1b. 20c; 1 ib. 50c.

Sweet German. Pkt. 5c; 1 oz. 10 ; 1/4 1b. 20c; 1 lb. 50c.

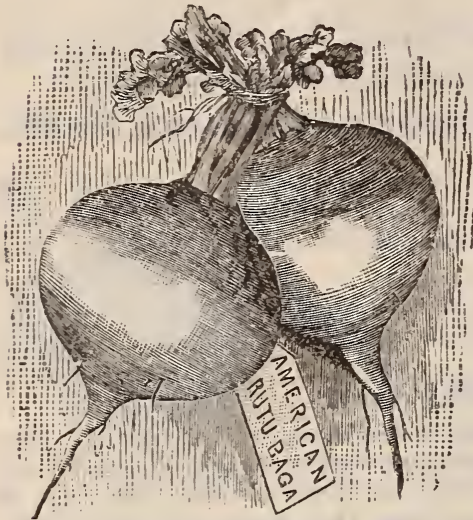

American Ruta-Baga.

\section{YELLOW FLESH VARIETIES.}

Yellow or Amber Globe. This variety is handsome, and grow- to a large size. Color, pale yellow. One of the best for general crop. Pkt. 5c; 1 oz. 10c; 1/4 lb. 20c; 1 lb. 50c.

Golden Ball, or Orange Jelly. It forms a bulb, having a beautiful bright-yellow rind and creamcolored flesh; rich, pulpy, and excellent for culinary use as well as for stock. Its keeping qualities are unrivaled. Pkt. 5c; 1 oz. 10; 1/4 lb. 2. c; 1 lb. 50c.

Yellow Aberdeen. Bulb globular, reddish purple and deep yel ow below; solid and hardy. Generally groun for farming purposes. Pkt. 5c; 1 oz. 10c; $1 / 4$ lb. 20c; 1 1b. 50c.

RUTA-BAGA, OR SWEDES.

The ruta-baga, or Swedish varieties, are grown principally for feeding stock, and are also excellent for the table early in the spring. Sow in drills two feet apart, from the middle of June until the first of August.

Improved American Purple Top. Th1s lariety is largely grown, both for table use and stock feeding Flesh solid, fine quality, keeps well. Pkt. 5c; $1 \mathrm{oz}$. $10 \mathrm{c} ; 2$ oz. $15 \mathrm{c} ; 1 / 4$ lb. $20 \mathrm{c} ; 1$ lb. $50 \mathrm{c}$; 5 lbs. postpaid, $\$ 2.00$.

Skirving's Purple Ton. This is a Grst-rale variety, hardy and priductive; flesh yellow, of solid texture; yrows to a large si,e; a very popular sort for market and field culture. Pkt. $5 \mathrm{c} ; 1 \mathrm{nz}, 10$; 2 oz. 15 c; 1/4 lb. 20 c; 1 1b. 50 c; 5 lbs. postpaid, $\$ 200$.

Monarch, or Tankard. Color purplish crimson above gruunit, yellow below. The $\mathrm{fl}-\mathrm{sh}$ is of the best qualitv. The roots grow much ahove grourd, making them easy to harvest. Produces an imnense crop. Pkt. 5c; 1 oz. 10c; 2 oz. 15 c; $1 / 4$ lb. 20 c; 1 lb. 50 c; 5 lbs. postpiid, $\$ 2.00$.

White Russian. Large, white and solid. l'kt. 5c; 1 oz. 10c; 1/4 lb. 20c; 1 lb. $50 \mathrm{c} ; 5$ lbs, postpaid, $\$ 200$

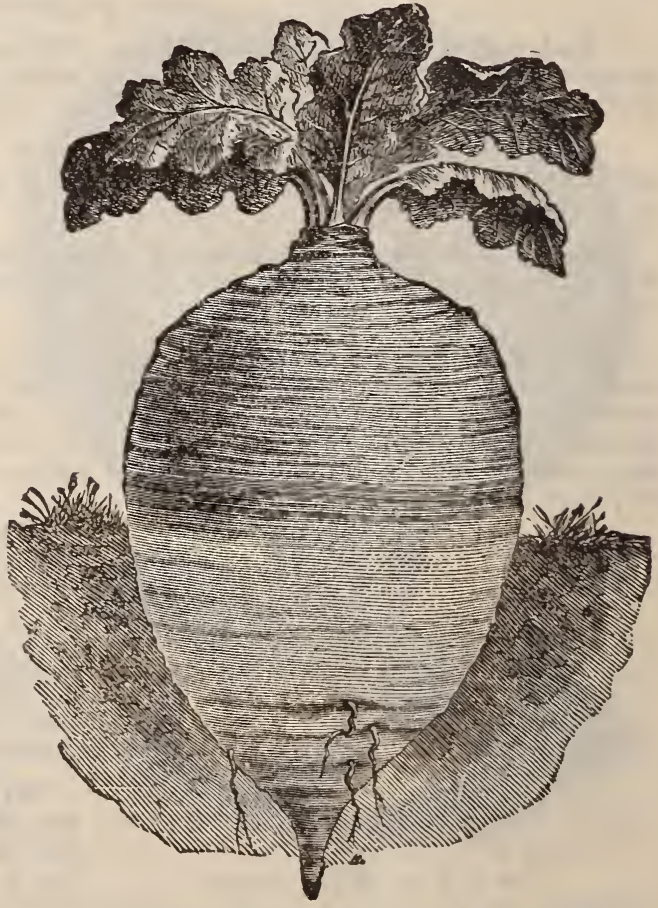

Monarch Ruta-Baga.

Fur all Veyetable Seeds, except those specially noted, ordered by express or freight at purchaser's expense, deduct loc. from single pound price. 


\section{HERB SEEDS--POT, SWEET AND MEDICINAL.}

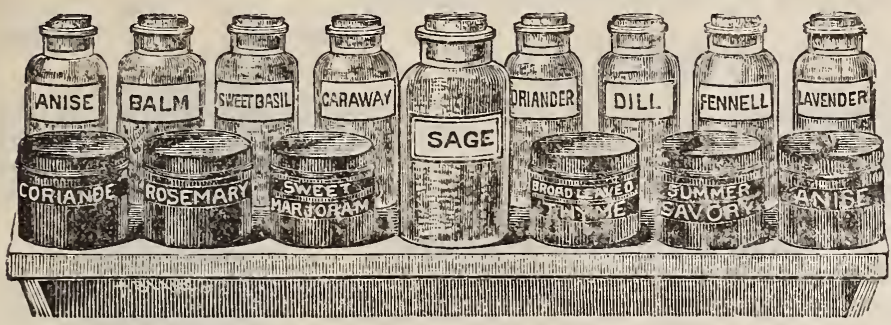

Herbs in general delight in rich, niellow soll. Thos e noarked with a $(*)$ are perennial, and when once obtained in the garden may be preserved for years with a little attention. Sow the seeds early in the spring in $\mathrm{s} \mathrm{h}$ a $110 \mathrm{w}$ drills one foot apart;

when up a few inches thin out to proper distances, or transplant.

(are should be taken to harvest them properly. This shnuld he done on a dri day, just before they come into full blossoni: dry quickly in the shade and pack ciosely in dry loxes ir ressels, so as to entirely exclude the air from the herb. We offer sone of the most useful and popular.

A nise. Pimpinella anisum. For garnishing and seasoning. The seeds are also used medicinally. Pkt. 5c; 1 oz. $10 \mathrm{c} ; 1 / 4$ 1b. $25 \mathrm{c} ; 1$ lb. $\$ 1.00$.

* Balm. Melissa officinalis. A fragrant, lemon-scented herb, used for making Balm tea or Balm wine. Pkt. 5c; 1 oz; $1 / 4$ lb. $80 \mathrm{c}$.

Basil, Sweet. Ocrmum Basillicnm. The leares and top shonts are useful for seasoning soups, stews and sauces. Pkt. $5 \mathrm{c} ; 1$ oz. $20 \mathrm{c} ; 1 / 41 \mathrm{~b} .50 \mathrm{c} ; 1 \mathrm{lb} . \$ 1.50$.

Borage. Borago officinalis. Leaves used for flaroring, ard flowers furnish bee pasture; must easily grow $\mathrm{n}$ in any waste place. Pkt. 5c; 1 oz. $15 \mathrm{c} ; 1 / 41 \mathrm{~b} .40 \mathrm{c} ; 11 \mathrm{~b} . \$ 1.25$.

* Ciraway. Carum carui. Cultivited for the seed, which is used extensively in cakes and confectionery. Pkt. $5 \mathrm{c} ; 1 \mathrm{oz} .10 \mathrm{c} ; 1 / 4 \mathrm{lb} 25 \mathrm{c} ; 1 \mathrm{lb} .75 \mathrm{c}$.

* Catnip. Nepeta Cataira. A mild nervine, excellent for cbildren. For winter use, remove the plant by the roots and dry as other herbs. Pkt. $5 \mathrm{c} ; 1$ oz. $50 \mathrm{c} ; 1 / 41 \mathrm{~b} . \$ 1.50$.

Coriander, Coriandrum sativum. The seed is used medicinally, in confectinnery, etc. Lenves are used for garnishing. Harvest the seed when perfectly drv, and bruise the leaves and break the stems as little as possible. Pkt. $5 \mathrm{c} ; 1$ oz. 10c; $1 / 4^{\prime} 1 \mathrm{~b} .25 \mathrm{c} ; 11 \mathrm{~b} .75 \mathrm{c}$.

Dil1. Anethum graveolens. Hardy annual; seeds arrmatic, $n$ as m and pungent; nsed medicinally and also for flavoring. Pkt $5 \mathrm{c} ; 1$ oz. $10 \mathrm{c} ; 1 / 4 \mathrm{lb} .25 \mathrm{c} ; 1 \mathrm{lb} .75 \mathrm{c}$.

Fenne1, Sweet. Foeniculum officnale. Leaves and seeds used for flavoring. Pkt. Бc; 1 oz. 10 c; $1 / 4$ 1b. 25 c; 1 1b. $75 c$.

Horehound. Marrubium vulgare. Pkt. $5 \mathrm{c}$ : $1 \mathrm{oz} .30 \mathrm{c} ; 1 / 4 \mathrm{lb} . \$ 1.00$.

* Lavender. Lavendula vera. Cultirated for the fragrance of its flowers. Gather when in full bloom and dry quickly. Pkt. 5c; 1 oz. 15c; 1/4 1b. 40c.

Marjoram, Sweet. Origanum marjoiana. A ferennial in warm rlimates. The young shoots and leaves are used for flavoring. Pkt. $5 \mathrm{c} ; 1 \mathrm{oz} .20 \mathrm{c} ; 1 / 4 \mathrm{lb} .50 \mathrm{c}$.

* Rosemary. Rosemarinus officinalis. The leaves have a prngert oror and warm, aromatic, bitter taste. The dry leaves lose their strength rafidly. $1 \mathrm{kt}$. $5 \mathrm{c} ; 1 \mathrm{oz} .3(\mathrm{c} ; 1 / 4 \mathrm{lb}$. $\$ 1.00$.

* Rue. Ruta gravenlens. Used medicinally. Pkt. 5c; 1 oz. 20c; 1/4 1b. 50c.

Sage, Broad-Ieaved. Salvia officinalis. Used as a condinient for relishes and for flavoring. A hardv perennial; should have rich snil and thorough cultivation. Cut the young shoots just bef,re blooming, dry quickly in the shade and store cartfully. Pkt. 5c; 1 oz. $20 \mathrm{c} ; 1 / 4$ lb. $70 \mathrm{c}$.

Savory, Summer. Satureia hortensia. Cultivated for the rourg shoots, which are dried and used for flavoring. It is a hardy annual. Pkt. 5c; $1 \mathrm{oz} .15 \mathrm{c} ; 1 / 41 \mathrm{~b} .40 \mathrm{c}$.

* Thyme. Thrmus vulgaris. A warm, pungent, very arcmatic plant, murh used for fluvoring soups, dressings, elc. It is also a nervine. It c: n le vsed eilher fresh or dried. Plant as early as the ground can be frepart. I'kt. $5 c ; 1 \mathrm{cz} .40 \mathrm{c} ; 1 / 4 \mathrm{lb} . \$ 1.00$.

Wormword. Artemesia ahsynthil $m$. Used for medicinal purfoses. It is also benefi.ial to pouliry and should be planted in poultry grounds. Pkt. $5 \mathrm{c} ; 1 \mathrm{oz} .30 \mathrm{c} ; 1 / 4 \mathrm{lb}$. $\$ 1.00$. 
VEGETABLE PLANTS.

CABBAGE PLANTS.

PER DOZ. $50 \quad 100 \quad 1000$

Postpaid. By Express.

Early Jersey Wakefield, best early...

Early IVınu gsta it ..............

$20 \mathrm{c} \quad 50 \mathrm{c} \quad \$ .50 \quad \$ 3.50$

$50 \mathrm{c} \quad .50 \quad 3.50$

Pı mium Late Hlat Dutch . . . . . . . . . . .

$35 \mathrm{c} \quad .40 \quad 3.00$

Premıum Late Drumhead.................... 15c

$35 c \quad .40 \quad 3.00$

CAULIFLOWER PLANTS.

Early varieties..............

$25 c \quad 70 c \quad 1.00 \quad 7.00$

Late varieties...............

$20 \mathrm{c} \quad 45 \mathrm{c} \quad .75 \quad 5.00$

TOMATO PLANTS.

Optimus, the best for canning................ 25c

Atlantic Prize, earliest tomato grown............. 2.. . .

Perlection, for main crop.................... $25 \mathrm{c}$

Firly Michigan ............................. 25

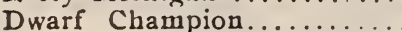

$25 \mathrm{c}$

$\begin{array}{lll}60 \mathrm{c} & .85 & 5.50 \\ 60 \mathrm{c} & .85 & 5.50 \\ 60 \mathrm{c} & .85 & 550 \\ 60 \mathrm{c} & .85 & 550 \\ 60 \mathrm{c} & .85 & 5.50\end{array}$

CELERY PLANTS.

Gollen Self-Blanching..........

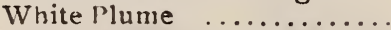

Giaut Pascal, best late..........

$\begin{array}{rrrr}20 c & 45 c & .65 & 4.50 \\ 20 c & 4.5 c & .65 & 4.50 \\ 20 c & 55 c & .65 & 4.50 \\ 30 c & 50 c & .85 & 5.00 \\ 25 c & 60 c & 1.00 & \\ 20 c & 60 c & .90 & 6.00\end{array}$

SWFET POTATO PLANTS...

PEPPER .................

KALE..................

$20 \mathrm{c} \quad 60 \mathrm{c} \quad .90$

6.00

Other varieties furnished if desired. No plants sent C. O. D.

Write for quotations if larger quantities are wanted.

\section{GARDEN ROOTS AND TUBERS.}

Transportation charges to be paid by purchaser, except as noted.

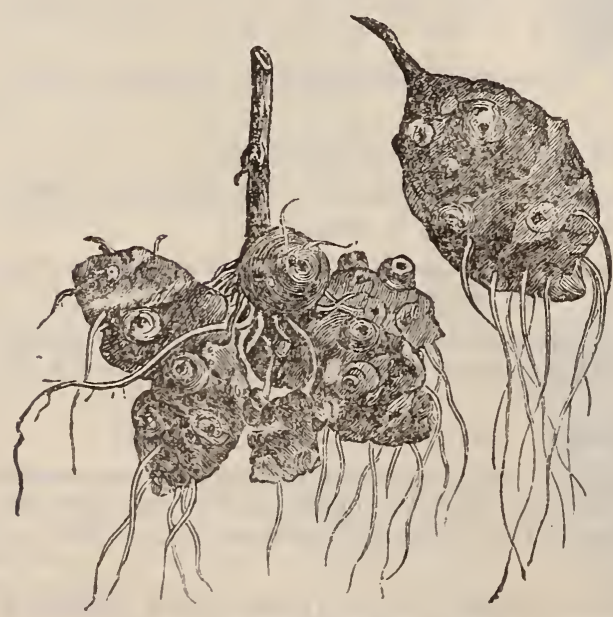

Artichoke, Red Jerusalem. The tubers grow similar to potatoes. They furnish one of the best foods for stock ever put on the market, being verv nutritious and healthful. Sow from one bundred and fifty to two hundred pounds per acre. They yield an immense crop. $1 \mathrm{lb}$. postpaid, $20 c ; 50 \mathrm{lbs}$. $\$ 1.00$. Write for special pi ices on large quantities.

Artichoke, White. Flesh white and sweet. 'Inis variety produce; larger tubers than the red, and a larger crop, and is now taking the lead. $1 \mathrm{lb}$. postpaid, 20c; 50 1hs. $\$ 1.00$. Write for prices on large quantities.

Acparagus, CONOver's COLOSSAI, Palmetto and Columbian Mammota W'HITE, either variety, 1 doz. postpaid, $35 \mathrm{c}$; $100, \$ 1.00 ; 1000, \$ 6.00$.

Artichokes.

Hop Vines. 1 doz. postpaid, 25c; 100, $\$ 1.00$.

Horse Radish. 1 dez. postraid, 25r; 100, 75c.

Rhubarb. 1-year, 1 doz. 50 c; by mail, 65 c.

Rhubaıb. 2-jear, 1 doz. 75 c; by mail, $\$ 1.10$.

Write for quotations if larger quantities are wanted. 


\section{GRASS AND CLOVER SEEDS.}

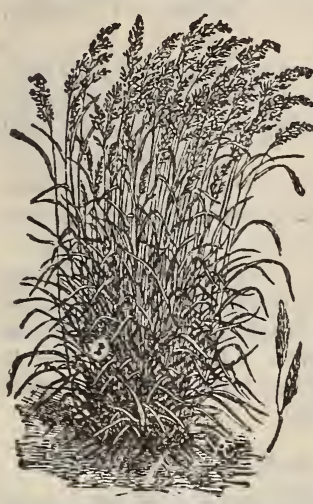

English Blue Grass. or Meadow Fescue.

Grass and Clover Seeds have become of so much importance to the agrisulturist within the last few years that we have deenerl it wi-e to pay special attention to the inatter of seeds for the production of these articles. We offer below the standard varieties of Grasses and Clovers for this section, and also some $v$ trieties which are, as yet, in the experimental stage with the farmers of the Coast. IVe shall be very glad to give anvinfurmatiinn which we may have along this line, an if anyone interested does not find such varieties as he wishes in this list, we slould be pleased $t$, have lim write us, for we sliould be verv glalt to procure whatever lie may wish, if we can. Prices subject to variation. to correspond with the market quotations, will be given on application.

\section{Add 10: per pound for postage when ordering by mail.}

Blie Grass, Canadz. Poa compressa. Differs from the Kentucky variety in its flattened wiry sten. Because of its creep. ing rout stalks it forms a fine turf; recommended in all pasture mixtures on dry soil, and thrives well on clay or hard-trouden and poor soil. $1 \mathrm{lb} .15 \mathrm{c} ; 100 \mathrm{lbs}$ \$15.00.

Blue Grass, English, or Meadow Fescue. Festuca pratensis. A perenntal variely growing three to four feet high. It roots deep, thus resisting drought better than most grasses. It suceels ou aity ordinarv soil; vields a heavy crop of superior hay; one of the be-t grasses for pastures, as it comes early and remains green untillate. Valuable to mix with other kinds. Use thirty pounds per acre wheu sown alone. $1 \mathrm{lb}$. $15 \mathrm{c} ; 100 \mathrm{lbs} . \$ 12.50$.

Blue Grass, Rentucky. Poa pratensis. One of the best grasses for permanent pasture, furnishing a constant supplv of the $m$ ist nutriti us feed cluring a greater part of the year. It is perennial, anl in warm loca ities where the ground is kept moist and is pastured or frequently cut to prevent the seed from ripening, will continue to yrow luxuriantly the entire year. It is also one of the best srasses known for lawns and parks, and, where treated with a dresins of fertilizer every fall, watered well and evenly and cut frequently, will furnish a handsome, velvety lawn for years, requiring 110 resowing. For pasture, sow forty or filty pounds to the acre, but to secure a fine lawn, much heavier seeding is required, and not less than ninety pounds should be sown. Fancy Clean, 1 lh. 20c; 100 lbs. market price. Extra Clean, 1 lb. $15 \mathrm{c} ; 100$ lbs. market price.

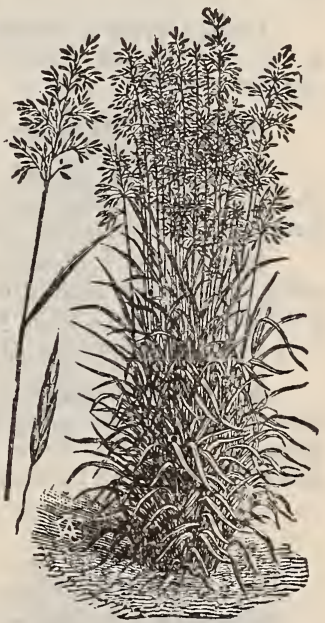

Bromus Inerimis.

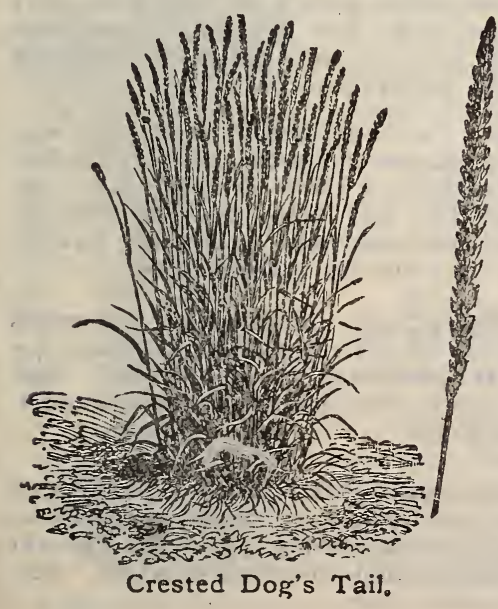

Bormus Inermis. Awnless Brome Grass.Russian Brome Grass. Valuable for :emi-arid lancls; yond for cutting and feeding in green state, for pasture or hay. Its sunning roo's tike a deep and permanent hold on the land, and it will prubablv replace, in a large degree, the fast-lisappearing Bun $h$ Grasses of Eastern Oregon and Eastern IVashington, where it has done well. Sow thirty.five to forty pounds to the acre. 1 1b. 20c; 100 lus. market price.

Bromus Schraderi. Rescue Grass. Also known as Bromus Unoiloides. Thrives in any soil, but prefers that which is wet or moist. In England, four or five green crops are cut in a year, and every tinie it is cut another cr ip shoots from the roots. All kinds of stock eat it freely. Thirty pounds to the acie. 11 b. 30 c; 100 1bs. $\$ 25.00$.

Crested Dog's Tail. Crnosurus cristatus. A rereınial grass with short, narrow leaves. particularly valuable for lawns or pastures on dry, light land. $1 \mathrm{lb}$. $40 \mathrm{c} ; 100 \mathrm{lbs}$. $\$ 35.00$. 
Creeping Bent Grass. Agrostis stolenifera. Valuable to mix with other pasture grasses nd it will thrive in mo lerately moist soil. Best for small grass plats or croquet groun is. Fur pasture, sow 18 to 36 pounds per acre; for lawns 36 to $48 \mathrm{lbs}$. $1 \mathrm{lb}$. 35c; 100 ib; m irket price.

Fl ating Fescue. Festuca fluitans. A peren rial with long creeping roots and preferring a ri.h muidy or alluv al soil. Fuund in ditches, along rivers, in marshv nlaces etc. Trout a id wild ducks are very fond of the seeds and tender shouts. $1 \mathrm{lb} .35 \mathrm{c} ; 100$ 1bs. market price.

Feicue, Sh sep's. Festuca ovina. Grows freely in high, dry and open pastures. Its chief merit for stuep pasture is that it occupies 1 and which better grasses refuse; grows froun six to te's inches high. Thirty five pounds to the acre. $11 \mathrm{~b} .25 \mathrm{i}$.

Fowl Mea low Grass, or False Red Top. Poa serotina. Yields well when sown on low unoist land, an 1 stand; linger in coudition for cutting than mont grasses. It can be mow-d alm ist anv time from July to October. When three feet high it falls down, or lodyes, anl alter a little time every joint puts forth new branches. The stalk is dlways sw et and tender, ind cattle and sheep are fond of it. Requires ab ut twenty-five pounds of seed per acre. S.Jw in spring or fall. Per lb. $40 \mathrm{c} ; 1001 \mathrm{bs} . \$ 28.00$.

\section{Hungarian Grass-See Millet, Hungarian.}

Lawn Grass, Choice. A good, strong-growing grass for lawns that will give satisfaction. Sow one hundred pound : to the acre, twelve to fifteen pounds to an ordinary city lot. $1 \mathrm{lb} 1 . \overline{\mathrm{c}}$; $10, \mathrm{lb}$. market price.

$L_{\text {i w }}$ Grass, Fancy. Is com sosed of the fineat and best mixture of neat, compactly growiun v rrieties, producing a fine sward. Suw $100 \mathrm{lbs}$. to the acre. $1 \mathrm{lb} .25 \mathrm{c} ; 100 \mathrm{lbs}$. market price.

\section{Meadow Fescue-See Blue Grass, English.}

$\mathbf{M} \geq a$ low Foxtail. $4 l$ pecurus pratensis. One of the very best for permanen pastu e. Do:s well on soil interme liate in moliture and derness. Sta ids in ense summe heat without burning. Sow $23 \mathrm{lbs}$. to the acre. $1 \mathrm{lb}$. 30c; $10 \mathrm{nlbs}$. market price.

Mesquite. Holcus lanatus. It is usuallv sown on virgin coil, without cultivation, after the timber is removerl and the ground burned over. It will grow on any loose soil. The seed is light anl chaffy, and care must be taken in sowing, the best time being just before rain. Use about thirty-five to forty pounds per acre. $1 \mathrm{lb} .10 \mathrm{c} ; 100 \mathrm{lbs}$. market price.

Millot, Common. A variety growing from three to four feet high, having rather broail blailes and strong stalks. It supplies a valuable bay crop and affurils excellent pasturage. It should have rirh mellow soil, well prepared. For a seell crop sow fifteen pounds per acre; for hay and pasture use thirty pounds. $1 \mathrm{lb} .7 \mathrm{c} ; 100 \mathrm{lbs}$. market price.

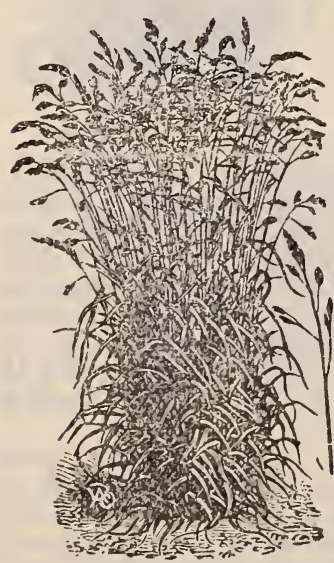

Orchard Grass.

Millet, German or Golden. Panicum Germanicum var An improved variety, yielding a larger crop of seed than the Common Millet. It is also taller than the Common and y'elds a heavier crop of hay. It will grow on any gond agricultural land and rields heavily when artificial water, if required, can he applied at the proper time. It yields from forty to sixty bu-hels of seed per acre. For a crop of seed, sow twelie to fi teen pounds per acre; for hav, twenty-five to thirty pounds. $1 \mathrm{lb} .10 \mathrm{c} ; 100 \mathrm{lbs}$. market price.

Millot, Hungarian. Panicum Germanicum. A dwarf annual Millet. It is filler than the Common and German Millets, but proriuces a clocer stand and yields almost as mucn per acre as the taller var eties. The hay being finer is preferred by stock. It wi l yield well on anv light, lonse soil. Sow 25 to $30 \mathrm{lbs}$. per acre. $1 \mathrm{lb} .10 \mathrm{c} ; 100 \mathrm{lbs}$. market price.

Millet, Pearl or Egyptian. Prorluces an ennrmnus amount of green feed. It can be cut repratedly, growing very rap.dly after cutting, and is equal to s. eet corn fir feed. Sow in drills two or three fert apart. Four pounds nill sow an acre. $1 \mathrm{lb} .30 \mathrm{c} ; 100 \mathrm{lbs}$. market price.

Orchard Grass. Dactylis glomerata. One of the most valuable of all the cultivated gras-e;, bliommng with Red Clover and making with it admirable h:y. As a pasture erass, it is more priductive than anv other. and does best under close feeding. It stands drought better than most other yrasses, keeping green and growing when others are dried up. Sow twenty-five pounds to the acre. $1 \mathrm{lb}$. $15 \mathrm{c} ; 100 \mathrm{lbs}$. market price. 


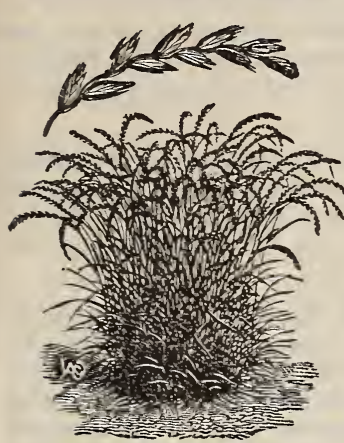

English Rye Grass.

Rye Grass, English. Lolium perenne. A stronggrowing, hardy, perenn1 1 grass, noted for its nutritive qualities. It is equ $11 \mathrm{y}$ valuable, both for grazing and hay, and will succeed on any good tillable land, if well prepared. Also makes a fine lawn, and for large grounds and pirks is very successful. Does not require the close care that the Blue Grass does, and will flourish better under trees or in shady lolations. For field crop, sow forty to fifty pounds to the acre; for lawns, not less than one hundred pounds. $1 \mathrm{lb} .10 \mathrm{c} ; 100$ 1bs. market price.

Rye Grass, Eng'ish. (American-Grown.) 1 lb. 9c; 100 lbs. market price.

\section{Rye Grass, French. (See Tall Meadow Oat Grass.)}

Rye Grass, Italian. Lolium Italicum. A perennial variety. One of its chiet points of merit is its rapility of growth. Where the seusons are short, either from limited rains or long, severe winters, this variety is found valuable. Though a distinct varietr, its qualities are similar to the Fnglish Perennial, and it will succeed on the same soils. From forty to fifty pounds to the acre should be sown. $1 \mathrm{lb} .10 \mathrm{c}$; 100 lbs. market price.

Red Top. Agrostis vulgaris. A good perennial grass. Generally sown on permanent pastures. It succeeds Clover and Timothy $u$ hen they have died out. D es well on any $s+11$, but bist on moist land. Sow twenty pounds to the acre. $1 \mathrm{lb} .10 \mathrm{c} ; 100 \mathrm{lbs}$. market price.

Rough-Stalked Meadnw Grass. Poa Trivialis. A most valuable grass, which flour shes in moist, ri, h soils and sheltered situations. It is highly nutritive, and oxen, horses and sheep are very partial to it. Twenty pounds to the acre. $1 \mathrm{lb} .30 \mathrm{c}$.

Sweet Vernal. Anthoxanthum odoratum. One of the earlie-t grasses in spring and litest in sutumn, and more fragrant than any other grass. Valuahle to put in pasture mixtures and Lawn Grass, on account of its earliness and its

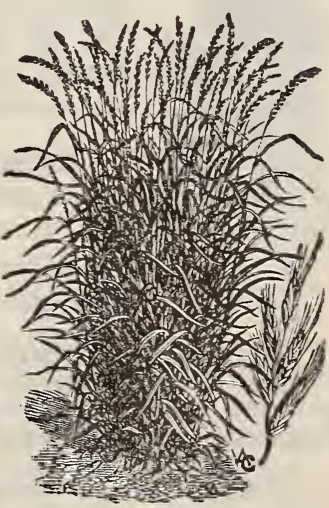

Italian Rye Grass. delightful fragranice when in bloom Sow about thirty pounds to the acre. TRUE PERENNIAI, 1 lb. $45 \mathrm{c}$; ANNUAL, 1 lb. $20 \mathrm{c}$.

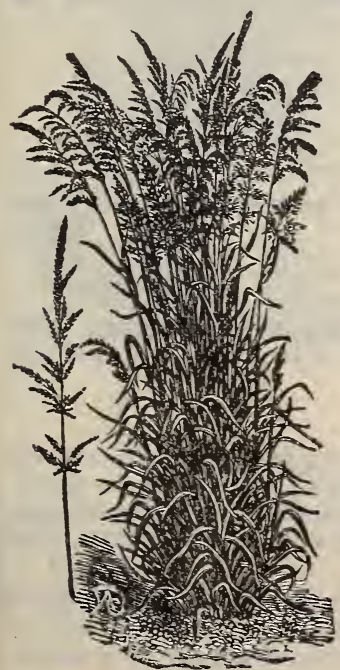

Tal1 Meadow Oat Grass, or French Rre Grass. Avena clatior. A valuable grass for permanent pasture: early, luxuriant growth and abundant supply, which is relished by cattle early and late; also makes splendid hay. Sow twenty pounds to the acre. $1 \mathrm{lb} .2$ ic, $100 \mathrm{lbs}$. market price.

Timnthy. Phleum pratense. As a grass to cut for bay this is unsurpassed. It does best on moist, loamy soils, and is not suited to light lands. $1 \mathrm{lb} .6 \mathrm{c} ; 100 \mathrm{lbs}$. market price.

Water Mead w Grass. Poa pratensis. An excellent and useful pasture g.a $\mathrm{s}$ for very wet places. Sow twenty pounds to the acre. $1 \mathrm{lb} .40 \mathrm{c} ; 100 \mathrm{lbs}$. market priee.

Wood Meadow Grass. Poa nemoralis. The early growth of this grass in the spring and its remarkably fine, succulent and nutritive herhage, recommend it strong'y for pastures. Thrives well under close feeding and is very valuable. rhirty pounds to the acre. $1 \mathrm{lb} .35 \mathrm{c}$.

Tall Meadow Oat Grass. 
Red Clover. Trifolium pratense. This is the most widely cultivated of all the pasture plants. It lonsens the soil an 1 admits the air, and absorbes nitrogen fron the air, making it one of the best green fertilizers, as well as a cattle food of the highest merit. Sow twelve pounds to the acre. $1 \mathrm{lb} .12 \mathrm{c} ; 100 \mathrm{lbs}$. market price.

Mammolh Red Clover. Trifolium pratense. Sinilar to Red Clover, hut coarser and taller, and consilered of more value fur reclaiming and enriching was' e lands, as it sustains itself and succeeds sometines where Red Clover fails. Sow from twelve to fifteen pounds per acre, in time to get the benefit of ample moisture. $11 \mathrm{~b} .13 \mathrm{c} ; 100 \mathrm{lbs}$. market price.

White Dutch Clover. Trifolium repens. A small variety, having a white blossom. It is ot a vining nature, spreading rapidly, and will soon cover bare spots if the stand he uneven. It dues nut attain sufficient height to be profitable for hav but is siperior for pasture either for cattle or sheep and un-urpasser fur the production of h'ney. It also makes a beautiful lawn, mixed with Blue Grass. When sown aloue, use eight or ten pounds per acre. Harrow the soil until it is very fine before sowing. $1 \mathrm{lb} .20 \mathrm{c} ; 100 \mathrm{lbs}$. market price.

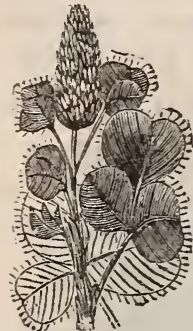

Scarlet

Clover.

Alsike, or Swedish Clover. Trifolium hybridum. Prohably a hybrid between the red and white, possessing qualities common t, both. Productive, sweet, permanent, extremely valuable both for pasturage and soiling. On low ground it does better than Red Clover. The flowers are a distinct light pink and afford fine pasturage for bees. Sow ten pounds per acre. 1 lb. 14c; $100 \mathrm{lbs}$. market price.

Crimson Trefoil, or Scarlet Clover. Trifolium incarnatum. Grows about one foot high; dark roots, long leaves, and blossoms of deep red. It makes good hay and will give two or three cuttings each season. One of the very best clovers for soiling. Fruit growers are now sowing it

Alfalfz, or Lucerne Clover. Medicago sativa. One of the most valuable of the clovers. It resi-ts the driest neatlier, and, when every blade of grass droops for want of moisture, it hold up fresh and green. It is the be,t variety to use on lands that have to be irrigated. Sow fifteen pounds to the acre. $1 \mathrm{lb}$. 10c; $100 \mathrm{lbs}$. market price.

Espersette Clorer, or Sainfoin. Onohrychia sativa. A hardy perennial rarietv. Yieldi a heavy crop of hav which is easily cured and greatly relished bi stock; excellent for pasturage as it remains green until late in the fall and makes a rapid growth early in spring. Has some of the cliaracteristics of Alfalfa and about the same nutritive value. Its roots penetrate to a great depth: is not injuriously affectrd by severe fos's. The sreils are large and should be sown thickly-forty to fifty pounds to the acre. $1 \mathrm{lb} .20 ; 100 \mathrm{lbs}$. market price.

\section{Write for prices on Grass and Clover Seeds.}

\section{FARM SEEDS.}

The prices are subject to the market fluciuations. Quotations on large quantities given on application.

\section{Add 10 cents per pound if wanted sent by mail.}

Red Kaffir Corn. Non-saccharine. The plant is low, stocky, perfectly erect. The whole stalk, as well as the blades, cures in is available for green feed. $1 \mathrm{lb}, 5 \mathrm{c} ; 100 \mathrm{lbs}$. market price.

White Kaffir Corn. 1 lb. 10c; 100 lbs. market price.

Spurry. Spergula Arvensis. An annual forage plant: coming into popular favor, on accoutut of its fine forage qualities and thriftv grouth on light, sandy, and on her poor lands. When germinated, it soon takes good hold of the soil. Sown in March, it is reaily for pasture in four or five weeks. Sow fifteen pounds to the acre. $11 \mathrm{~b} .20 \mathrm{c} ; 10 \mathrm{lb} . \$ 1.20 ; 100$ lbs. \$\$.100.

Sacaline. Polvgonum sachalinense. A hardy perennial. Its merits as a forage plant have only lately been pointed out. It grows well on the poorest soils, is perfectly hardy, and enclures the extremes of heat and cold. The stems and leaves. which are very uutritious, are eaten by cattle and sheep. Pkt. 10c; 1 oz. $40 \mathrm{c} ; 1 / 4 \mathrm{lb} . \$ 1.25 ; 1 \mathrm{lb}$. $\$ 4.50$. 
L ithyrus Sylvestris. Also called flat pea. A perenniai furage plant, growing well on very pur, utituproved andy soil: can withstand pretty severe frosts; roots so deeply that it is not inj ired by severe drouth; yields superior lorage for all farm stock, and has excellent qualities as a fertilizer. Pkt. $5 \mathrm{c} ; 1 \mathrm{oz}$. 20c; $1 / 41 \mathrm{~b}$. $50 \mathrm{c} ; 1 \mathrm{lb} \cdot \$ 1.50$.

Fenugreek. An annual plant; very fragrant. The seed is often sought by hostlers to give a temporary fire and vigor to their hor:es. It is frequently given to oxen and pigs whe 1 fat'ening, causing them to drink and to digest their food. Considered to be good for soiling when green. Pkt. 5c; 1 oz. $10 \mathrm{c} ; 1 \mathrm{lb}$. $35 \mathrm{c}$.

Barley. For seed. $1 \mathrm{lb} .3 \mathrm{c} ; 100 \mathrm{lbs}$. market price.

Buckwheat, Common. Buckwheat should be sown about the midrle of June, broadcast, at the rate of from thirty to fort-6ive poinds to the acre. It should be threshed as soon as dry. If allowed to stand in mass, it quickly gathers moisture. $1 \mathrm{lb} .5 \mathrm{c} ; 100$ lbs. $2.7 \overline{0}$.

Buckwheat, Silver Hull. This improved variety is much better than the old sort. It is $i_{1}$ bloom $l$ mger, matures sooner and yields $h$-avier per acre. The grain is of a beautiful liglit gray color. Buckwheat makes splendid bee pasture. $1 \mathrm{lb} .5 \mathrm{c} ; 100 \mathrm{lbs} . \$ 3.00$.

Buckwheat, Japanese. This variety excels all others. Will vield much heavier than ally other, and it ripens one week to ten days earlier, stands up hetter, and makes better flour than any other kind of buck wheat. $1 \mathrm{lb}$. 5c; $100 \mathrm{lbs} . \$ 3.50$.

Field Peas. 1 lb. $5 \mathrm{c} ; 100$ lbs. $\$ 2.50$.

Flax Se ad. Prime, clean seed for sowing. 1 lb, $10 \mathrm{c}$ : $100 \mathrm{lbs} \$ \$ .00$.

Rape. Dwarf Essex. For sowing. Good for sheep pasture. May be sown in May, or even after taking off a crop of potatoes. Fall sowing will also give good results. Inder moderately favorable circunistances will furnish a large amount of pasture or forder. In drills, sow five pounds to the acre; broadcast, ten pounds to the acre. $1 \mathrm{lb}$. $15 \mathrm{c}$; 100 lbs. market price.

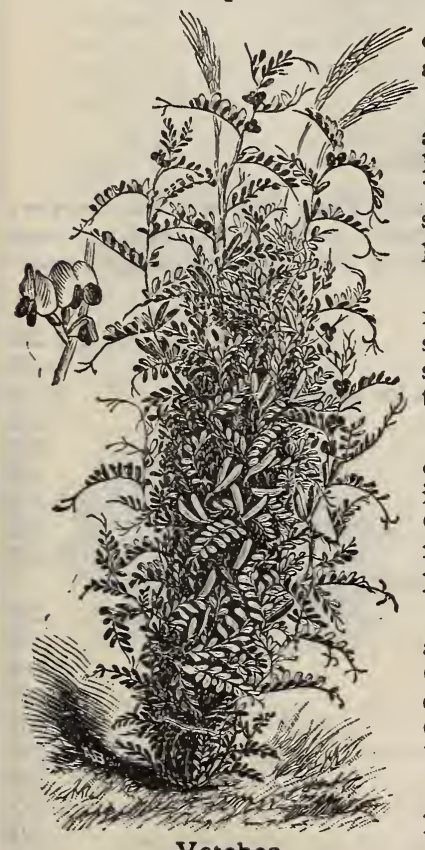

Cow Peas. Good for fodder, sheep being very fond of them when in flower. Their chief value, however, is as a green crop, to plow under. $1 \mathrm{lb} .15 \mathrm{c} ; 100 \mathrm{lbs}$. $\$ 6.00$.

Idaho Pea, or Coffee Berry. A forage plant valuable for semi arid lands. Yields excellent crops of feed for horses, cattle, sheep and poultry. The peas, when nicely browned and ground, make an excellent bererage. Plant sparingly for seed, clostly for fetd. 1 1b. 15c; 100 lbs. price given on application.

Soja Beans. A very valuable fodder plant, either for feediny green or for the silo. It is a rich food, and is unsurpassed for forming flesh. Like clover, it improves the soil by drawing its nitrogen from the air. Very productive. $1 \mathrm{lb} .15 \mathrm{c} ; 100 \mathrm{lbs} . \$ 8.00$.

Spring Vetches, or Tares. Vicia sativa. A species of the pea; grown extensively for stock feeding. It is coming to be ricognized as one of the best forage plants for Oregon and Washington. Also very valuable for green manuring. Culture same as for Field Peas. Sow one bushel per acre with wheat or oats. $1 \mathrm{lb}$. $7 \mathrm{c} ; 100 \mathrm{lbs} . \$ 4.00$.

Winter Vetches. Vicia villosa. Perfectly hardy and very nutritious. Thrives on poor, arid, sandy soils. Can be cut twice for fodder and again for seed. Sown either in fall or spring, generally with rye for a support. Grows three to four feet high. Sow at the rate of $11 / 2$ bushels to the acre. $1 \mathrm{lb} .15 \mathrm{c} ; 100 \mathrm{lbs} . \$ 10.00$.

Cheat Seed. Now being used quite extensively for hay. $1 \mathrm{lb} .5 \mathrm{c} ; 100 \mathrm{lbs}$. market price.

\section{BIRD SEEDS, ETC.}

Add 10c. per pound for postage when ordering by mail.

Canary Seed, Hemp Seed, Rape Seed, Sunflower Seed, Mixed Bird Seed, Mixed Seed for Parrots, each 10c. per lb. or 3 lbs. for 25c. Lettuce Seed, 1 oz 5c; 1 lb. 40c. Mocking Bird Food, per bottle, 50c. Bird Manna, per cup. 20c. postpaid. Bird Gravel, package, $10 \mathrm{c}$; in bulk, $5 \mathrm{c}$. per $1 \mathrm{~b}$. Moulting pepper, box 55c. posipaid. Cuttlefish bone, 5c. ea. 


\section{TREE SEEDS.}

Purchaser to pay transportation charges on all quantities above one pound.

App'e Seed. American. For nurstry stocks. 1 oz. 10c; 1/4 lb. 15c; $1 \mathrm{lb} .40 \mathrm{c}$.

App'e Seed. French Crab. 1 oz. 10c; 1/4 1b. 20c; 1 1b. 50c.

Cherry Pits, M zzzard. Cerasus. For nursery stocks. $1 \mathrm{oz} .10 \mathrm{c} ; 1 / 1 \mathrm{lb} .15 \mathrm{c}$; $1 \mathrm{lb}$. tic.

Cherry Pits, Mahaleb. $1 \mathrm{oz} .10 \mathrm{c} ; 1 / 4 \mathrm{lb} .20 \mathrm{c} ; 1 \mathrm{lb} .50 \mathrm{c}$.

Peach Pits. For nursery stocks. 1 lb. 20c; 100 lbs. $\$ 1.50$.

Penr Seed. Pvrus Communis. The best imported. For nursery stocks. $1 \mathrm{oz} .15 \mathrm{c}$; $1 / 4$ lb. $4 . \bar{c}$; 1 lb. $\$ 1.5 \mathrm{v}$.

Pear Seed, Native. 1 oz. 20c; 1/4 1b. 50c; 1 lb. $\$ 1.75$.

Plum Pit6. Prunis myrabolano. For nursery stocks. 1 oz. 10c; 1/4 1b. 20c; 1 lb. 50c

$Q$ ince Seed. $1 \mathrm{oz} .20 \mathrm{c} ; 2$ oz. $30 \mathrm{c} ; 1 / 4$ lb. $50 \mathrm{c} ; 1 \mathrm{lb} . \$ 1.65$.

Box Elder, or Ash Ieaf Maple. Acer negundo. $1 \mathrm{oz} .10 \mathrm{c} ; 2$ oz. 15c; 1/4 1b. 20 c; $1 \mathrm{lb} .6 \mathrm{uc}$.

$H$ rse Chestnut, or Buckeye. $1 \mathrm{lb} .35 \mathrm{c}$.

Lucust, Yellow or Bl ck. A tree of rapid growth. Sown in our Western statee for timber. $10 \% 10 \mathrm{c} ; 2 \mathrm{oz} 15 \mathrm{c} ; 1 / 4 \mathrm{lb} .20 \mathrm{c} ; 1 \mathrm{lb} .50 \mathrm{~s}$.

Incust, Honey. 1 oz. $10 \mathrm{c} ; 2 \mathrm{oz} .15 \mathrm{c} ; 1 / 4 \mathrm{lb} .20 \mathrm{c} ; 1 \mathrm{lb} .60 \mathrm{c}$.

Write for Prices on large quantities.

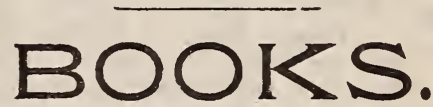

We offer a list of valuable books for the Girdener, Farmer, Fruit Grower, Bee Keeper, Poultriman aud o hers in similar lines. Do not fail to inform yourself, by reading some $g$ wid look on the line you are especially interested in. Any of them will be mailed postpaid at the prices named.

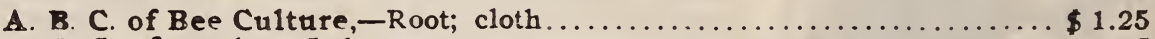

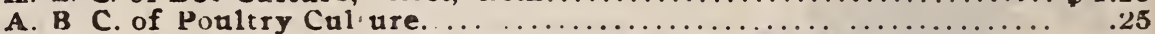

American Standard of Perfection, - The Standard for scoring poultry... 1.00

Art of In ubation, -Von Culin .................................. 83

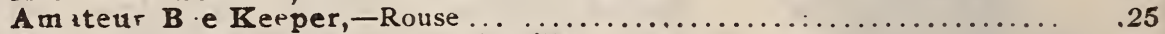

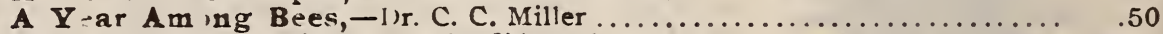

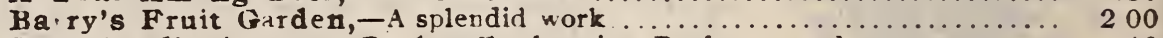

Blanchard's Accunne Book, - For keeping Poultry records............. $\quad .40$

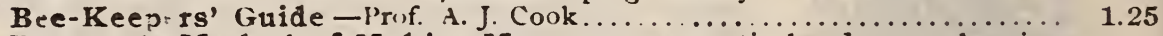

Bommer's Method of Making Manures, - a practical and comprehensive

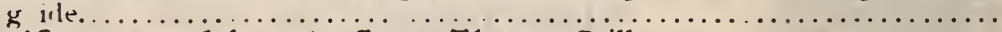

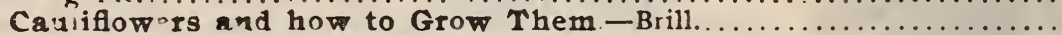

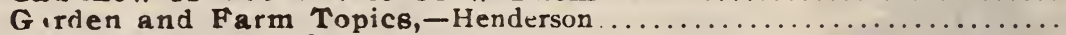

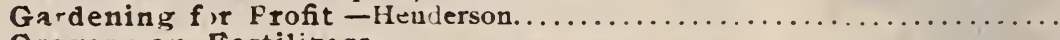

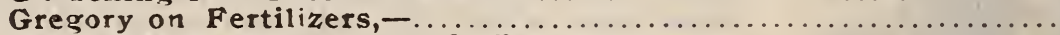

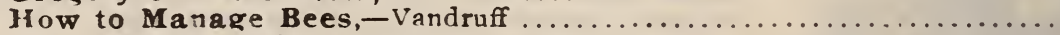

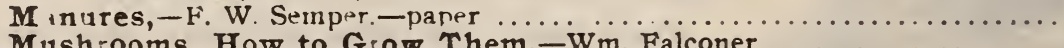

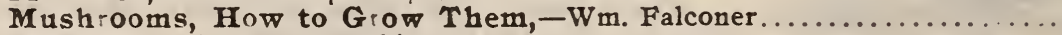

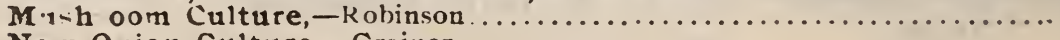

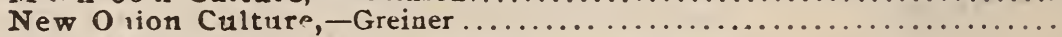

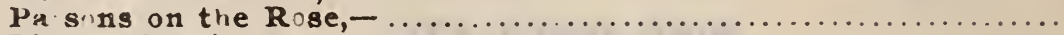

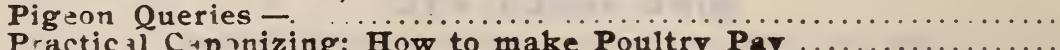

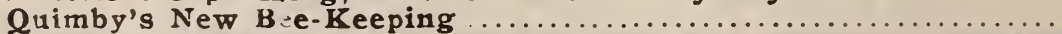

The $\mathbf{R}$ ise, - El wanger.

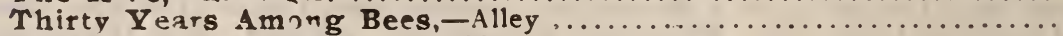

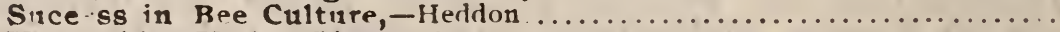

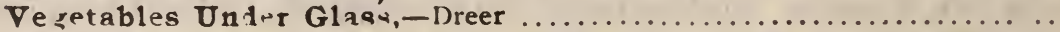

500 Questions and Answers. 


\section{FLOMVER SEEDS.}

Flowers are divided into three classes-Annual, Biennial and Perennial. The annuals are those flowers that bud, blossom and ripen their seed the first season and then die. The annuals are valuable to both the amateur and professional gardener. To th $m$ we are mainly indebted for our brightest and best flowers in the late sunımer and autumn mon hs.

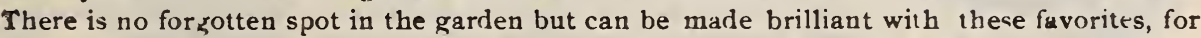
there is no situation nor soil in which some of the annuals will nol flourish. Biennials and Perenn als are those flowers that live on for two years or more, and, with but few exceptions, do not blossom the first season. The seed should be sown in the early spring, nith the annuals. Great care should be taken in preparing the soil tor the sowing of $f$.wer B sides teing enriched, the ground should be thorouxhly pulverized and the seeds but lightly covered, for but few flower seeds have sufficient strength to push their way up through clods of dirt or a very heavy stiffness of soil.

Acacia. Tender shrubs with fern like foliage and fine racemes of tragrant flowers. MiXED. Pkt. 10c.

Ageratum Fine for bouquets, and useful for beds, borders and pot plants. The flowers are graceful tufts of fine peta's that remain fresh a long time after being cut. Blooms all summer. and if protected or potted and taken indoors, will bloom all win ter. Thrives well during long, dry summers. Half-hardy annu al. Mexicanum, Blue. Pkt. 5c.

Agrostemma. Striking and beautiful for beda, rihbons and borders Their yraceful pink-like flowers remain fresh, after be'ng cut, a long time, and are very handsome in bouquets. Thrives in any good soil. Coronaria (Rose Campion). Mixed. Perennial. Pkt. 5c.

Agrostis. Ornamental Grass. A hardy, annual, ornamental grass: delicate and graceful; very beautiful and effective, with everlasting fowers. For winter bouquets. NEBULuSA. Pkt. 10c.

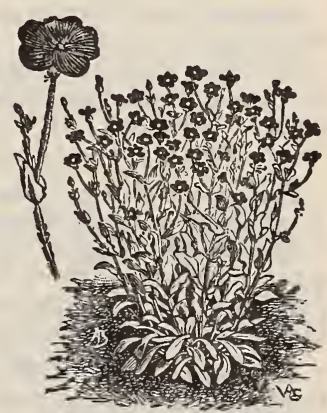

Aglooctenusid.

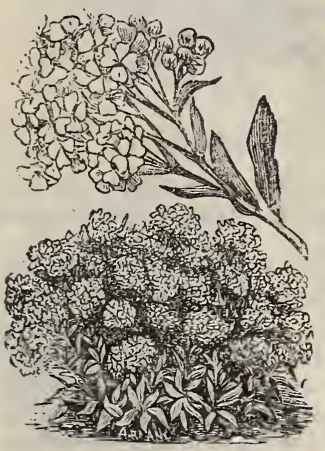

Sweet Alyssum.

Alyssum. The Alyssums are well-known hardy annuals of easy cultivation. effective in beris, an:: especially fine for horders and edgings. The White Sweet Alyssum possesses a delicate, agreeable fragrance, and is very poutlar for bouyuets. If taken in or protected they $\mathrm{will}$ blosscm all winter. WHITE SWEET, Pkt. 5c. SAXatile, Gulden Alyssum, Pkt. 5c.

Amaranthus. Graceful, easily-grown ornamental foliage plants for the flower garden or conservatory. The colors are brighter if not planted in too-rich soil. Half hardy annual. MELANChOlicus Ruber. Dwarf habit; deep red foliage. I'kt 5c. Pkt. 5c.

Caudatus. Love lies bleeding. Graceful drooping flowers.

CRUENTUS. Prince's feather. Handsome, erect flowers. Pkt. 5c.

TRI-COLOR. Joseph's Coat. Beautifully variegated; foliage scarlet, yellow and green. Pkt. 5c.

Aster. Very beautiful and popular half-hardy annuals, growing from ten to eighteen inches high. For profu-ion of flowers and richness of display, the Asters are unrivalled. Sow the seed early in the spring under glass, or in pots in the house, and transplant into rich soil about one foot apart.

COCARDEAU, OR CROWN. The flowers of this variety hare large white centers, bordered with scarlet, carmıne, violet or blue; attractive and beautiful; one and one-half foot. Pkt. 10c.

CRYSANTHEMUM Flowered. Large double flowers resembling Chrysanthemums. Valuable on account of profuse late flowering. Rose, Mixed; each, pkt. 10c.

GERMAN QUILLED. Double, quilled flowers of beaut.fully mixed colors; two feet. Plt 5c.

Imbricated Pompon. White, 10c. Choice Mixed. Pkt. 10c. 


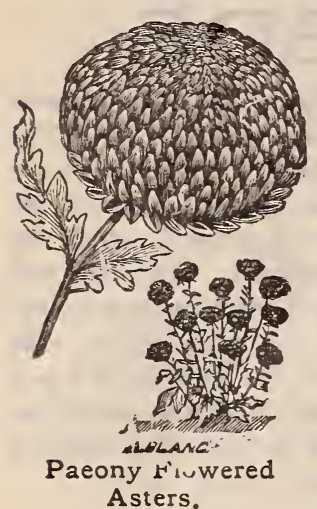

Giant Comet. The plants of this magnificent new tribe of Asters are tuelve to fifceen illches high and furm regular pyramids completely covered with superb, larye, diuble fuwers four to five inches across with long wavv, twisted petals, rest mbling the finest Japanese chrysanthemums. Pure White, Crimson, Mixed, each, pkt. 10c.

TRUFFAUT'S PaFONy FrotverEd. The earliest flowering variety: very double, fine: Snow White, Crimson, Apple Blossom, Dark Blool Red, Light Blue, Mixed; ear:h, per pkt. 10c.

SEMPIE'S LATE FloweriNg BRAXChING AS Ffrs. Flowers are large, four inches across, very duuble, of pure-t colors, borne on long stems. They begin b:ooming about the first of September and continue until frost. Plant; eighteen inches to two feet high. White, Pink, Rose, Crimson, Lavenler, Mixell, each, pkt. 10c.

VICTORIA. Very lar se; perfectly double form: one and threefourths feet. Mixed, IVhite, Light Blue, Scarlet; each, pkt. 10c.

Vick's Branching. Mixed, pkt. 10c.

Bachelor's Button. Centaurea cyanus. Corn Flower, or Corn Botlle. A hardy annual of easy cultivation. Has recently been greatly improved, and now produces handsome flowers of a great variety of rich colors. Borne on tall, hrancbing stems, with but little fo. liage. Striking and handsome. CHOICE MIXED. Pkt. $5 \mathrm{c}$.

Balloon Vine. Cardiospermum. Love-in.a-puff. A climbing annual, having rather inferior flowers u hich, however, are folloned by curious puffs or balls that are quite handsome, from which it takes its name. The plant is graceful and attractive and used for either greenhouse or outdoor decoration. Pkt. 10c.

Balsam. Ladies' Slipper, Touch-Me-Not. Exceedingly haudsome and attractive plants, producing masses of various colored flowers. The soil should be very rich and free. The plants can be pinched back so as to form bushes of any clesired shape. Tender annual. Easily grown. TALL DOUBLE IVhITE. Extra choice. Pkt. 10c.

CAMELTIA-FLOWERED DOUBLE. Pkt. 10c.

DWARF DOUBLE. Mixed. Pkt. 10c.

TALt, Double. Mixed. Pkt. 5 c.

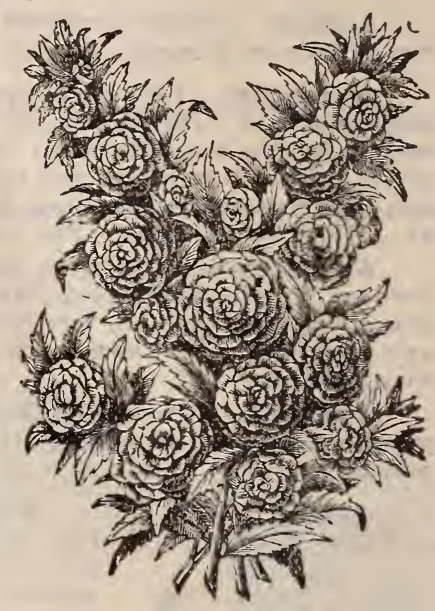

Balsam.

Brachycome. Swan River Daisy. A handsome, dwarf-growing, free-flowering annual from Australia. The blossoms resemble Cinerarias. CHOICE MIXED. Blue and White. Pkt. 10c.

Briza. Handsome ornamental grass. Bears graceful pods on slender stems, which quiver with the slightest motion. Fine for winter bouquets. Hardy annual. Maxima. Large. Pkt. 5r.

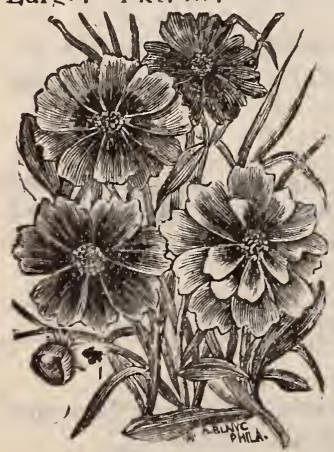

Calliopsis.

Calceolaria. A very handsome and much admired perennial, desirable either for the greenhouse or outdoor culture. producing a profusion of beautifully spotted and tigered fowers of unique form. They flower best in a rich, santy loam, and can be propagated either fron: the seed or cuttings. Tigered and spotted; brilliant. Hybrida Mixed. Pkt. 5c.

HYBRIDA RUgosa. Handsome, shrubby, profuse bloomer, most desirable for outdoor culture. Pkt. $5 \mathrm{c}$.

Calliopsis, or Coreopsis. Also known as Black-Ered Susan. A hardy annual. Very showy and attractive. It is branching, and is covered with a mass of bright flowers of all shades of yellow, orange and gold, with a dark vrlvetv center. Suw where they are to remain and cut the flowers when in full bloom. CHOICH MIXED. Pkt. 5c.

Canary Bird Flower. Tropaenlum canariense. One of the hest climbing plants, with graceful foliage of a delicate shade of green, and snisll rellow hlissom, which u hen half expanded, has a fancied resemblance to a canary bird. Half hardy auuual. Yellow. Pkt. 10c. 
Canna. Indian Shot. Majestic appearing plants, bearing broad, massive leaves, and crimson, scarlet and yellow flowers. CRozy. Mixed. Best varieties. Pkt. 10c.

Catchfy. Silene. A hardy annual about one foot high. Mixed. Pkt. 5c.

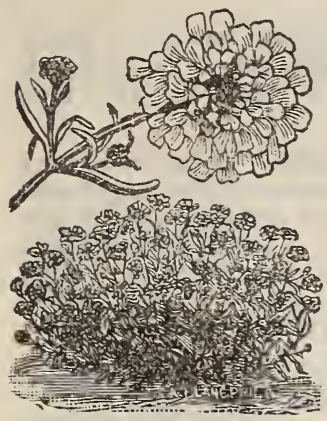

Candytuft.

Candytuft. Iberis. Well-known, hardy plants, thriving almost anywhere, and producing a profusion of bright, cheerful flowers. Very usefut for cut flowers, borders, ribbons or for conservatory decoration. Hardy annuals. CARMINE. Pkt 5c.

ODORATA. Sweet scented. Pkt. 5c.

MIXED. Anuual. All colors. Pkt. 5c.

SeMPervir ENS. Perennial. White. Pkt. $5 c$.

Carnation. Dianthus carophyllus. A well-known, halfhardy perennial. Most varieties have flowers of delicious fragrance, which are large and beautiful. Grows one-half foot high. Extra choice Double. Mixed. Pkt. 20c.

\section{COMmon DOUBle MIXED. Pkt. 5 c.}

MARGARET. If sown early in the spring, will flower the first year. Very popular. Doubl z and half dwarf Rose, White, Striped and Yellow, each 20c pet Pkt. Giant Mixed, pkt. 10c.

Canterbury Bel1. Campanula medium. Very ornamental yarden plants. Their large, bell-shaped flowers are borne on tall, graceful stalks and are produced freely throughout the summer. Hardy biennials. Very sbowy and attractive. Double. Mixed. Pkt. 10c.

Single. Mixed. Pkt. 5c.

Castor Bean. Ricinus. Highly ornamental, half hardy annuals, of stately growth and having large leaves of bronze or glossy green. By planting singly or in groups, a striking effect is produced on lawns or pleasure grounds. SANGUINEUS. Brilliant scarlet. Pkt. 10c.

BARBONIENSIS ARBOREUS. The largest variety. Tall and statel 1. Pkt. $10 \mathrm{c}$.

Mixnd. Best varieties. Pkt. 5c.

Clarkia. A very beautiful hardy annual, about eighteen inches hish, bloom ng from June to September. Set six inches apart. MIXED. Pkt. 5c.

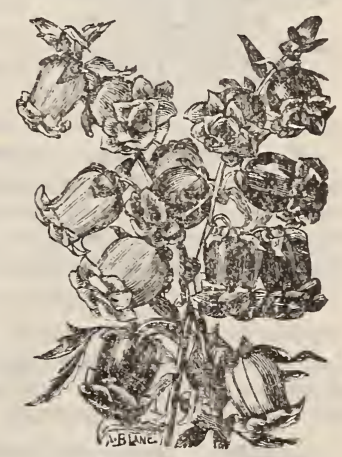

Canterbury Bell.

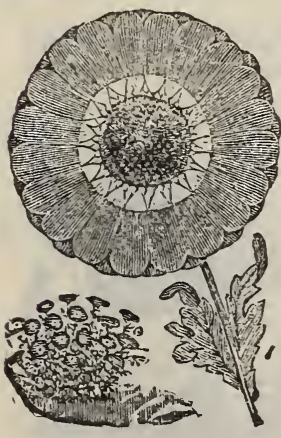

Chrysanthemum Annual.

Celosia Plumosa. Graceful, free-blooming plants. They belong to the same fanily as the cockscomb, but produce their flowers in beautiful feathery plumes, instead of combs. They can be grown in pots for the conservatory, or may be planted out after dauger of frost is past. Half-hardy annuals. Mixed colors of great brilliancy. Pkt. 10c.

Chrysanthemum. Annual. Handsome, hardy annuals, about two feet high, blooming from July to October. MIXED. Pkt. 5c. TriColor. Double. Pkt. 5c.

FRUTESCENS. Marguerite or Paris Daisy. Pkt. 10c.

Centaurea. Also known as Dusty Miller. This genus embraces some of the finest silver foliage plants in cultivation and, when arranged side by side in figures or in borders with dark and other ornamental foilage plants, rival in beauty the finest flowers. Sow early under cover or later in open ground and transplant when two inches high. CANDIDIssima. Handsome silver foliage. Leaves deeply indented. Half-hardy perennial. Pkt. 25c.

Cineraria. Well-known, free-floweriug greenhouse plants. The flowers are very brilliaut, and of great variety of colors. They can be planted when the weather becomes settled, and propagate readily by dividing the roots. Perennial. HyBRID. Extra selected. Single. Pkt. 25c.

Coboea Scandens. A useful climber of rapid growth; fine foliage and large, blue flowers. In sowing, place the seeds edgewise and cover lightly. Half-hardy perennial. Pkt. 10c. 
Cockscomb. Celosia Cristata. Very ornamental and interesting plants, producing crest-like flowers of great beautr, resembling a cock's comb. The tufts of some varieties grow to an enormous size, and their feathery graceful appearance and brilliant colors ren. der them rery attractive. Half-hardy annuals, of easy cultivation. MIXED. Finest varieties. Pkt. 5c

Columbine. Aquilegia. A hardy perennial, producing handsome flowers of many bright and attractive colors. The seed may be sown as soon as the ground can be prepared. Can also be increased by dividing the roots. Best double varieties. MIXED. Very fine. Pkt. 5c.

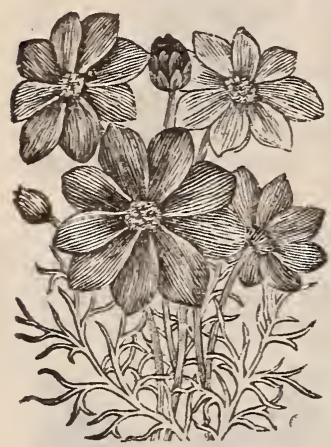

Cosmos.

Cosmos. Also known as Mexican Dahlia. A tall branching annual, of easy cultivation. haring delicate neeble-shaped foliage. The flowers which are produced in profusion are unusually bright and attractive, resembling single Dahlias. Colors range through rose and purple to pure white. A most desirable plant for autumn blooming. One of the most popular varieties grown, and deservedly so. Choice Mamiroth Mixed. Pkt. 10c.

Miammoth PeRfection. Fancy Light Pink. Pkt. $10 \mathrm{c}$.

Mammoth Perfection. Fancy White. Pkt. 10c.

Manmoth Perfection. Fancy Crimson. Pkt 10c.

Cyclamen. Presents a neat and elegant appearance, witb its curious shaped and various colored flowers and masses of green and variagated leaves. The seed produces a bulb that blooms the second season. Giganteum hiybridum. Pkt. $25 \mathrm{c}$.

Gigan'teum Persicum. Mixed. Pkt. 25c.

Cypress Vine. Ipomea quamoclit. A climbing annnal of rapid growth, having handsome fern-like foliage and a profusion of bright, attractive flowers. When furnished a suitable support they become very ornamental and showy. Plant the seed where they are to remann as soon as the ground becomes thoroughly warnied. WHITE. Pkt. $5 \mathrm{c}$. SCARLET. Pkt. 5c. Mixed. All colors. Pkt. 5c.

Dahlia. The Dahlia is very easily raised from seed. Both the Single and Double Dahlias present a variety of color and perfection of form not exceeded by any other flower. If sown early in spring most of the plants will bloom the first season. The tubers should be taken up in the fall and kept in a dry, cool place over winter. DOUBLE MrXED. Pkt. 15c. SINGLE MIXED. Pkt. 10c.

Daisy. Bellis perennis. A well-known, half-hardy perennial, blooming early in spring. Very desirable for borders. Sow early under cover, if necessary, and transwlant when well started, to a moist, shaded place. The roots can be divided. DOUBLE MIXED. Pixt. $15 \mathrm{c}$.

Datura. Trumpet Flower. Half-hardy, perennial plants, producing large, sweetscented, trumpet-shaped flowers. Succeeds in almost any soil. FASTUOSA. Double mixed. Pkt. 5c.

Eschscholtzia. California Poppy. Golden Cup. A showy, free-flowering genus of plants, bearing handsome, graceful foliage and flowers of the richest colors. They bloom very early and should be planted as soon as the ground can be prepared, where they are to remain, as they will not bear transplanting. Hardy annual, thriving best in light, warm soil.

California. Yellow, orange center. Pkt. 5c. Mixed. Pkt. 5c.

MANDARIN. The petals are of an orange color inside and brilliaut scarlet on the outside. Pkt. $5 \mathrm{c}$.

Echinocystis Lobata. Wild Cucumber. A rapid-growing climber, very good for covering old fences or trellises. Pkt. 5c.

Feverfew. Matricaria capensis. A free-flowering, ornamental, hardy annual, desirable for bedding or pot culture. It produces beautiful white flowers, very double. Handsome for bouquets. Sow early and plant out in pots or open ground. Pkt. $10 \mathrm{c}$.

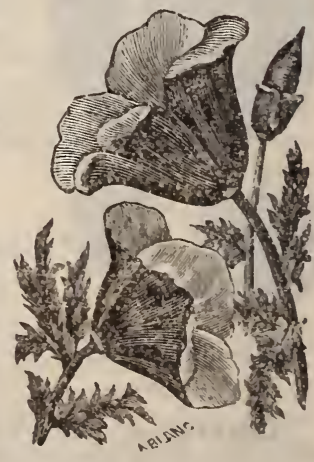

California Poppy.

Forget-Me-Not. Myosotis. I,ow-growing, popular, perennial plants, blooming the first season if sown in the fall or very early in spring. Fine for borders and edgings. A constant and profuse bloomer. Flowers mostly blue, with white or yellow center. IrGHT BLUE, haudsome. Pkt. 10c. Mixed. Choice, all shades. Pkt. 5c. 
Four O'Clock. Mirabilis. Marvel of Peru. A well-known hardy annual, growing luxuriantly in any ordinary soil, and bearing a profusion of bright, handsome flowers of various colors, shades and markings; from scarlet through pink to white, and from salmon through orange, gold and straw to white. Each plant produces self-colored and variegsted flowers. Some varieties are fragrant, and some have ornamental foliage. They are tall and branching, and should have plenty of room. CHOICE MIXED. Pkt. 5c.

Fox Glove. Digitalis. A tall-growing biennial, with large leaves and spikes of various colored and spotted flowers. Greatly improved of late, and are now really magniflcent plants. EXTRA MIXED. Pkt. 5c.

GLOXINIA-FLOWERED. Pkt. 5c.

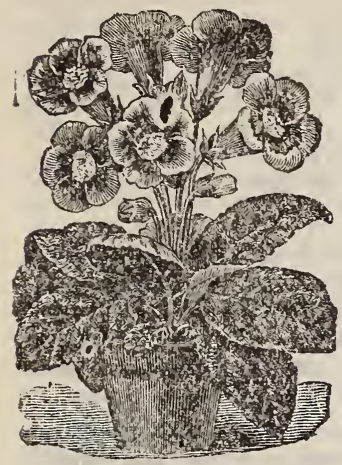

Gloxinia.

Gaillardia. Beantiful, showy annuals, one to two feet high. PICTA. Crimson and yellow. Hardy; with root protection in wiuter becomes perennial. Pkt. 5c.

Gilia. A hardy, easily.grown annual, having delicate, graceful leaves and handsome flowers, of a great variety of attractive colors and shades. MIXED. Pkt. 5c.

Globe Amaranth. Gomphrena. Extremely handsome everlastings. The flowers should not be cut until fully matured; will keep for years, and are fine for fresh-cut flowers, and almost indispensable for winter bouquets. Half-hardy anuual. MrXED. Pkt. 5c.

Gloxinia. Beautiful greenhouse plants. They grow well in a light, rich soil. HybridA Mixed. Pkt. 50c.

Godetia. Beautiful plants of easy cultivation, producing large, showy flowers. Hardy annuals of dwart habit. Recently much improved. MIXED. Pkt. 5c.

Golden Feather. Pyrethrum parthenifolium aureum. Desirable border plant. Foliage delicate, beautifully fringed, of a bright, golden tint. To secure the most elegant borders, cut out the flower spikes as fast as they appear. Hardy perennial of easy cultivation. Pkt. 10c.

Grevillea Robusta. The Silk Oak. Very beautiful and graceful foliage; highly valued as a decorative plant for the table, and, when large, for tropical lawn effects; tender perennial, 3 to 5 feet. Pkt. $10 \mathrm{c}$.

Gourds. Cucurbita. Rapid-growing, tender, trailing annuals of easy cultivation. Useful for covering walls, fences and unsightly places. The fruit of many varieties is elegant and curious, nd some may be used as dippers, bottles, etc. Dish CLO'TH. Pkt. 5c.

EGG-ShaPED. White, very useful for nest eggs. Does not crack or decay. Pkt. 5c.

DIPPER OR BOTTLE. Useful and handsome. Pkt. $5 \mathrm{c}$.

MIXED. Seed from the best varieties. LARGE VARIETIES, SMaII, VARIETIES, each, Pkt. 5 c.

Gypsophila. Delicate, useful, free-flowering plants, for baskets, edgings, or winter bouquets, for which purpose they should be gathered when in full bloom and dried in the shade. Annual and perennial. MURALIS. Pink, hardy annual. Pkt. 10c.

Panicui,ata. White. Best for winter bouquets. Hardy, perennial. Pkt. 10c.

Helichrysum. Everlasting Flower. Very ornamental, hardy annuals for the gar. den, and one of the best of all for winter bouquets. Gather when partially opened and dry in the shade. Will thrive in any good garden soil. DOUBLE MIXED. Pkt. $5 \mathrm{c}$.

Heliotrope. Delightfully-fragrant, free-blooming, tender, perenuial plants. Splendid for bedding or pot culture. The fragrance of its flowers cannot be excelled in exquisite delicacy. Invaluable for bouquets. MIXED. Choice. Pkt. $10 \mathrm{c}$.

Hibiscus. Fine, showy plants, with glossy leaves and large, brilliant flowers. In bloom throughout the entire season, and if potted and removed indoors will bloom all winter. Hardy annuals, of easy cultivation. ExTRA Mixed. Pkt. 10c.

Africanus. Yellow and Brown. Pkt. 10c.

Hyacinth Bean. Dolichos. Rspid-growing, ornamental, climbing annual, bearing clusters of beautiful purple and white flowers, followed by highly ornamental sfed pods, Plant where they are to remain, as they do not bear transplanting. LABLAB. Mixed. Pkt, 10c, 


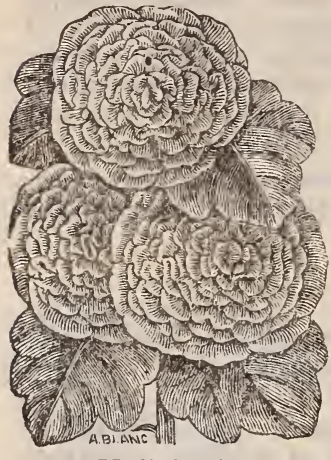

Hollyhock.

Hollyhock. Althea. The Holly hock has been greatly improved, the double varieties $\mathrm{b}$. ing now almost as perfect as C' mellias, and quite as varied and brilliant in color. Their majestic stalks, crowded on all sides with magnificent flowers, are a sight not soon to be forgotten. Our seed is saved from a rery large collection of the best strains. Perennials of easy cultivation. DNUBle Mixed. (hoice. Pkt. 5c.

Golden Yellow. Double. Choice. Pkt. 10c.

White Double. Very large. Pkt. 10c.

SCARLET, superb; Pkt. 10c.

Black, White Margin. Pkt. $10 \mathrm{c}$.

Charter's Superb. Mixed. Pkt. 5c.

Ice Plant. Mesemhryanthemum crystallinum. A dwarf, succulent, trailing plant for er'ging, rock-work, hanging baskets and vases The stems and leaves are very curiouily covered with crystals resembling $x$ lobul 's of ice, from which it takes its name, and which give it a very remarkable and brilliant appearance in

the sun. Tender annual. Pkt. 5c.

Ipomopsis. Standing, or Tree Cypress. Beautiful plant, with fine, feathery foliage, and long spikes of dazzling orange and scarlet flowers. Very effectic e for cons ${ }^{\star}$ rvatory or outdoor decoration. Prefers a dry, warm situa ion. Half-hardy perennial. Mrxed. Pkt 5c.

Iantana. Free-flowering, shrubby plants, suitable for outdoor or pot culture. The flowe's emit an agreeable odor, and are of many shades of purple, orange and white. Halfhardy perennial. MIXED. Finest Hybrids. Pkt. 10c.

I arkspur. A very ornameutal class of profuse-blooming plants, with tall spikes of many colored flowers. Hardy annuals end perennials. The perennial can be multiplied by dividing the roots. DWARF German Rucket. Mixed. Annual. Pkt. 5c.

Tall-branching, Stock-Flowered. Mixed. Perennial. Pkt. 5c.

Iinum. Beautiful, slender, free-flowering plants of many bright colors. Hardy annuals and perennials. Very showy. BEST MIXED. Many colors and shades. Pkt. 5c.

GrandiFlorum RUBRUm. Crimson Flax. Pkt. 5c.

Lewisi VARIEgatum. Blne Flax. Pkt. $5 \mathrm{c}$.

Lobelia. Delicate, low-growing annual plants, of the greatest value for borders, ribbons, edyings, rock-work and hanging baskets. The seed is very fine, and can be sonn early in boxes, or, a little later on, in open ground and the plants transplanted. CRYSTAL, Palace Compacta. Very Dwarf. Blue. Pkt. 10c.

ERINus Gracilus. Blue. Pkt. 10c.

FINEST MIXed. Pkt. 10c.

Marigold. Calendula and Tagetes. The Marigolds are well known, hardy annuals of easy cultivation. They are really magnificent flowers. The colors are gold, orange and varying shades of these colors. They flower early and bloom all summer.

AFrican. Double Mixed. Pkt. 5c.

French. Double Mixed. Pkt. 5c.

Mignonette. Reseda. A well-known, hardy annual. Perennial it protected. Produces abundantly spikes of exceedingly fragrant flowers of different colors. The flowers should all be cut when in full bloom, as the plant soon exhausts itself in maturing seed. By sowing at intervals, flowers can be had during the whole season. No garden is complete without it. Easily grown. Odorata. The well-known, large-flowering Mignonette. Pkt. 5c.

PARSON's WhITE. Nearly white and very fragrant. Pkt. 5c.

Gor,DEN QUEEN. Dense dwarf growth. Pkt. 5c.

ALLEN'S DEFIANCF. The largest variety and intensely fragrant. Pkt. 10c.

MACHET. Dwarf. Fragrant red flowers. Good for pot culture. Pkt. 10c. Pkt. 10c.
MACHET, Gorden. Similar to the above, but yellow in color.

Moon Flower Ipomea Mexicana grandiffrra. Rapid-growing annual. Covers an arbor, trellis or lattice work, twenty feet high, in eight or ten weeks. The flowers are large, waxy white and very showy. They open out on cloudy days and in the evenings. Pkt. 25c. 
Morning Glory. Convolvulus Major and Minor. The tall varieties are popular, well-known, rapid growing climbers, or the easiest cultivation. Valuable in every garden for trdiling on fences, arbors and verandas. The Minor or Dwarf varieties flower very freely and do not require support. The flowers are very showy and run through various colors from white to dar $\mathrm{b}$ blue and red. Plant early where they are to remain, if possible. Hardy annual. Convolvulus MiJin. Choice Mixed. Tall. All colors. Pkt. 5c.

Convor,vulus Minor. Dwarf. Mixed. All colors. Pkt. 5c.

IMPERIAL JAPANESE. Many beautiful varieties are included in this mixture. There are solid colors, ranging through reds from soft rose to crimson, bronze and garnet maroon; from daintiest light blue to ultramarine, indigo and blackish purple; from snow-white to cream and silver-grey. Sonse are str ped, blotched and spotted; others have magnificent edges and throats; including purple with white edge and red throat; carmine with white edge and red shaded throat; garnet with white throat, etc. Mixed. Pkt. 10c.

Musk Plant. Mimulus moschatus. Cultivated for its rich, musky odor. Annual; becoming perennial in warm climates. Should have a rich soil and ample moisture. Pkt. 10c.

Nasturtium. Tropaeolum. Both the leaves and flowers of the Common Tall Nasturtium are very handsome for table decorations. The leaves are also used, when young as salad, an I the seeds gathered while green and tender are esteemed by many for pickles. Sce Vegetable List. The Lobbianums are, however, superior to the common varieties when desired for ornamental purposes only. The flowers are larger, more compact, richer and more varied in color; produced more abundantly and contrast charmingly with the bright, clean, luxuriant foliage. Fragments of the vine, cut and placed in vases, will remain fresh and bloom for many days. The Dwarf Varieties have also been greatly improved, and are now among the most attractive bedding and border plants. All Nasturtiums are rapid growers, flowering best where the soil is not too rich. Hardy annuals.

TALI VARIETIES.

Brood Red. Pkt. 5c. Bright Scarlet. Pkt. 5c. Carmine. Pkt. 5c.

\section{SCHILlingIr. Bright Yellow. Pkt. 5c.}

GoLDEN YELLOW. Pkt. 5c. Separate colors; each, $20 €$ per oz.

MADAME GUNTER's HYBRids. A new race from France, having a richness of color and a vaijety of brilliant shades and markings hitherto unknown. Pkt. $5 \mathrm{c} ; 1 \mathrm{oz}, 15 \mathrm{c}$.

Lobbianum Varieties. The very finest flowering kinds. Mixed. Pkt. 5c; 1 oz. 20c.

COMMON VARIETIEs. Fine Mixed. Pkt. 5c; 1 oz. $10 r$.

\section{TOM THUMB DWARF VARIETIES.}

Dark Crimson. Pkt. 10c. Goldẹn King. Fine. Pkt. 10c.

EMPRESS OF INDia. New. Dark leaves. Crimson flowers. Superb. Pkt. 10c.

PEARL IVHITE. Pkt. 10c. Seperate colors; each, 20c. per oz.

FINEST MIXED. All colors. Choice. Pkt. $5 \mathrm{c} ; 1 \mathrm{oz} .15 \mathrm{c}$.

Nemophila. Love Grove. A dwarf, very free blooming plant, with flowers of various colors. Fine as a border plant. Fine Mixed. Pkt. 5c.

Oenothera. Evening Primrose. A pereunial of strong growth, opening its blossoms late in the afternoon; $h=n c \in$ the name. Quite attractive when covered with a mass of flowers. Pkt. $5 \mathrm{c}$.

Pampas Grass. Gynerium argenteum. A noble, perrenuial, orbamental grass, easily grown from seed, producing majestic plumes that are inimitable for winter decorations. They are used in their natural silvery state, or died any desired color. When well dried, take by the stalk and shake thoroughly to bring out their beatiful plume-like appearance, and when dusty and fading, it will restore them. The plants will bloom the second year. Pkt. $10 \mathrm{c}$.

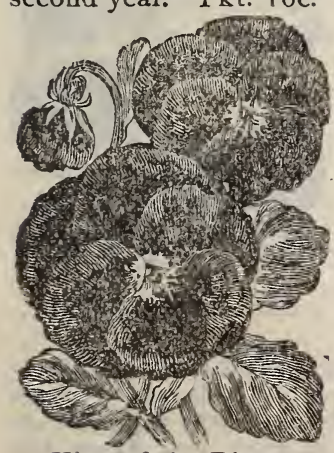

King of the Blacks.

Pansy. Viala tricolor. See cover for representations of our fancy strains. The pansy is one of the most popular anuuals, and justly held in bigh esteem. It furnishes a prolusion of bright, showy flowers of a great variety of rich colors and shades and markings, throughout the entire season, the flowers remaining perfect a long time. It should have the richest soil, abundant moisture, and a shaded locality. We give a choice list, every one of $\mathrm{w}$ hich, we feel cunfident, will give satisfaction, as we have taken the greatest care to procure the very best seed.

FAUST, OR ISING OF THE BLACKS. This is an exceptionally fine strain of this handsome variety, and we recommend it highly. Pkt. 10c.

Imperialis or Odier PRize Pansies. Extra quality. Pkt. 20c. Paristan LARgest SPOTTED. New, very large flowering. Pkt. 15c.

Coguette de Poissy. New, Mauve. Pkt. 20c. 


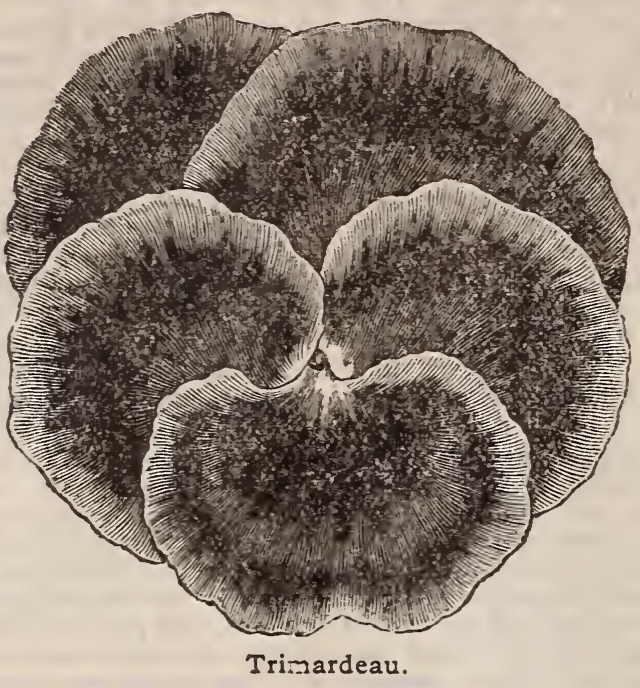

Trimardeatr. Our stock of Trimardeau Pansies is the very finest strain that can be obtained. The flowers are of im. mense size and exquisitely marked. Do not fail to plant some of them.

TriMARDEAU White. Pkt. 15c.

TRIMARDEAU YelLow. Pkt. 15c.

" MARBLED ON WHITE

GROUND. Pkt. 15c.

“ MARBLED ON YFLLOW

GROUND. Pkt. 15c.

“ VIOLET BLCE. Pkt. 15.

" KING OF THE BIACKS.

Pkt. 15c.

“ STRiPED. Pkt. 15c.

" MIXED. Pkt. $15 \mathrm{c}$.

VICTORIA. Claret Red. Pkt. 15c.

BRONZE. Pkt 5c.

SNow QUEen. Pure White. Pkt. 5c.

LIGHT BLUE. Pkt. 5c.

MAMMOTH MIXED. Pkt. 20c.

EXTRA MIXED. Pkt. 5c.

BUGNOT'S SUPERB BLOTCHEN. Pkt. 25c.

Cassier. Three and five blotched giant. Pkt. 20c.

EMPEROR WILLIAM. Indigo; dark center. Pkt. 5c.

Pres. Carnot. A fine new variety of the Odier type. Each of the five petals has a large dark violet blotch, leaving a broad margin of pure white. Produces large flowers in great profusion during the entire summer. Pkt. 25c.

FANCY StRIPED. Large flowered. Pkt. 10c.

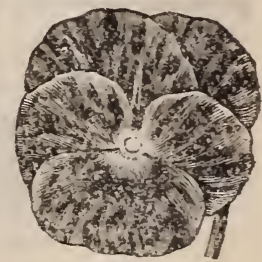

Fancy Striped.

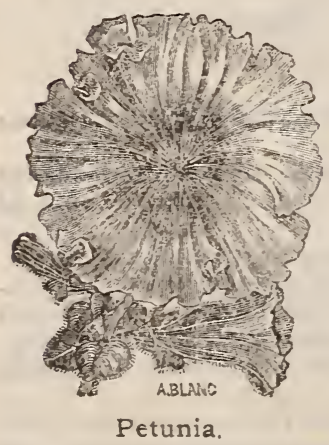
duration in bloom, combined with their almost unequaled richness of co: or, render them of invaluable service in the general fower garden, and a finer sight than a bed of Phlox Drummonlii is scarcely ever to be seen. Falf hardy annuals. GRANDIFLORA. FINE MIXED. Ykt. 5c.

LARGE Flowering White. Pkt. 5c. Coccinea. Deep scarlet. Pkt. ठ̈c.

Brack Warrior. Deep Purple. Pkt. 5c. Perennial. Pkt. 10c.

Pink. Dianthus. The flowers are of the richest and most pleasing colors, and nothing can surpais the exqui.ite fragrance of some varieties. Thev are hardy and become perennial in warm ciimates and when protected. New seed should be sown every vear or two. Old plants fuil rapidlv. Young ones produce the greatest number and much the finest flowers. Chinese Frore Pr, so. Double China Pink. Finest Pink. Pkt. $5 \mathrm{c}$. 
Primrose. Primula vulgaris. English Primrose. The old farorite yellow Primrose, now so popular and fashionable. Pkt. 10c.

ChInese Primrose. Primula Sirensis. Well-known green bouse and conservatory winter-blooming plants. Nothing can surpass them for pot and indoor-blooming plants. Their various forms and blending of colors are exceedinglv pleasing and $\mathrm{ffect-}$ ive. They thrive best in a soil of sandy loam and leaf muld. Tender perennial. Fimbriata. Choice fringed varieties. Mixed, Pkt. 25c.

Doubl.E. Extra Mixed. In great variety. Pkt. 25c.

Portulaca. Very popular, low-growing, hardy annuals, making a most brilliant display in the garden and rery suitable for borders and engings. Sow early, in warm, light soil, and thin plants to four inches. All colors. SiNgle MiXed. Pkt. 5c.

Finest Double MIXED. Pkt. 10c.

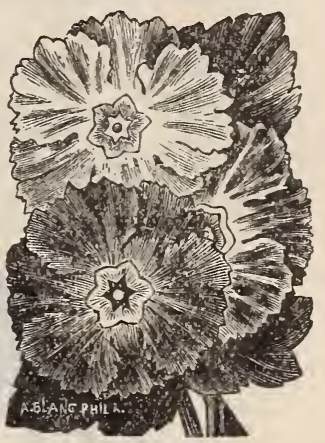

Primrose.

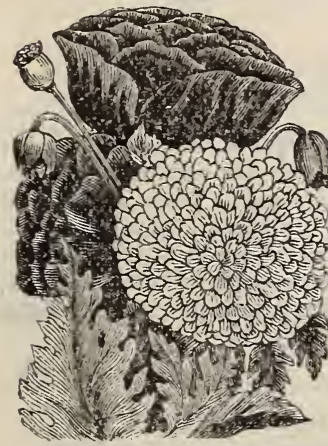

Poppies.

Poppy. Paparer. The Poppy is a well-known and really magnificent flower. The flowers are borne separately on tall stalks, both double and single, and of many bright colors. They are harly annuals, and may be sown as soon as the ground can be prepared. Carnation. Double-mixed, beautiful flowers of many colors. Pkt. 5c.

Double Scarlet. Pkt. 5c. Double White. Pkt. 5c. WMBROSUM. Rich vermillion, with a glossy black spot on each petal. Pkt. 10c.

The Shirley. Of glossy, satiny texture, but ranging through many colors. Pkt. 5c.

Bracteatum. Hardy perennial. Very showy. Red. Pkt. 5c.

Rhodanthe. A valuable dwarf everlasting flower. Succeeds best in a light, rich soil and a warm, sheltered situation. Cut as soon as fullv blown, and dry in the shade. Half hardy annual. Extra Mixed. All colors. Pkt. $5 \mathrm{c}$.

Salpiglossis. Pretty, ornamental annuals, bearing richly-colored, iunnel-shaped flowers; marbled yellow, crimson, scarlet, purple and blue. LARge-Flowered. Fine MiXed. Pikt. 5c.

Scabiosa. Mourning Bride. Handsome flowers, of delicious fragrance, borne on long. branching stalks that have but little foliage. The flowers resemble in appearance some varieties of Dahlias, and are very symmetrical and handsome. Colors various, from white to purple and scarlet. Half-hardy perennial, of easy cultivation. FINest Doublr Mixun Dirarf. All colors. Pkt. šc.

Salvia. Ornamental Sage. Very ornamental, producing tall spikes of brilliant flow. ers. Siw early in hot-bers and transplant two feet a vart. Splendens. Scarlet. Pkt. 5c.

Patens. Brilliant Blue. Pkt. 25c. Coccinta Lactea Milk Whi.e. Pkt. 10c.

Sensitive Plant. Mimosa. A peculiar plant, with globular heads of pink flowers; interesting on account of the irritability of its leares and stalks, which will, on being touched or shaken, close and droop as if dead. Tender annual. Pudica. Pkt. 5c.

Smilax. The most useful and beantiful of all climbing plants for florists. It can be trained from pots or hanging baskets around windows and over ceilings with charming effect. Tender perennial. Pkt. 10c.

Snapdragnn. Antirrhinum. One of the most useful and showv of horder plants. Of almost every color, and striped as beautifullv as Carnations. The flowers are singular in form, and, when taken between the finger and thumb and alternately presserl and released, will open and close with a snapping motion, from which thev take their name. Hardv perennials of easv cultivation. Tall Mrxed. Pkt. 5c. DWarf Mixed. Pkt. 5c.

Sunflowar. Helinnthus. A well-known plant, adapted hy its steady growth for a background to the lawn, or a screen to hide unsightly places. It is also grown as an absorbent of miasma in damp or ill-drained situations. The flowers, especially of the double varieties, are really quite attractive. (See also Vegetable List.) Hardy annuals. Globe Shaped. Pkt. 5c.

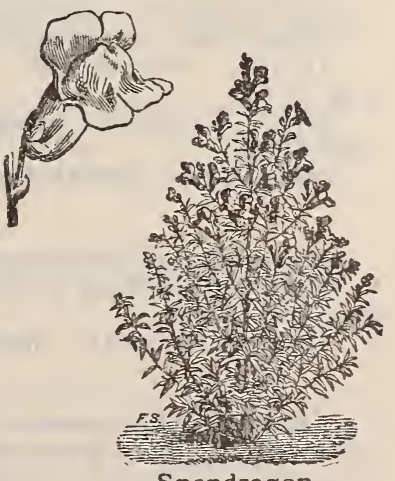

Snapdragon.

Californices. Double Orange. Pkt. 5c. 


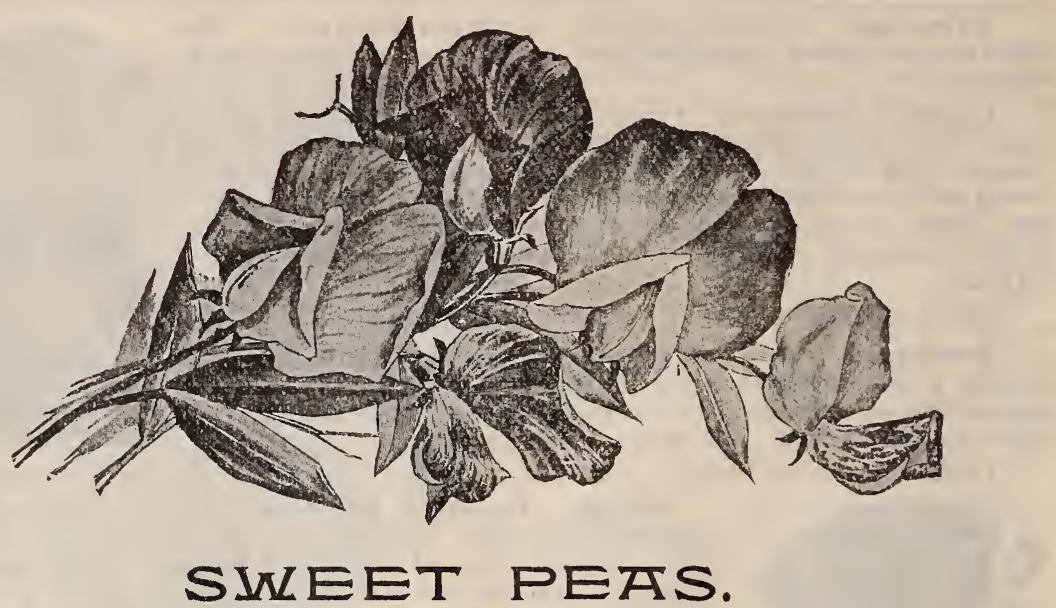

The Sweet Pea is today one of the most popular flowers for bouquets, table and parlor decoration. Their variety of beautifully contrasted colors, clear, fresh appearance, and delicious, refreshing fragrance, make the r appearance always inviting. Thev should be planted near some suitable support, in any good garden soil, and kept well-watered. We give a list of choice named kinds, and our mixtures include a large assortment of the best named varieties. Our stock is from the largest Sweet Pea growers in the United States, and is equal in quality to that offered by any Eistern firm. We offer them at the following prices except as otherwise noted. Pkt. 5c; 1 oz. 10c; 2 oz. 15c; 1/4 lb. 25c; $1 \mathrm{lb} .75 \mathrm{c}$.

\section{WHITE.}

- BlanchF BURPEE. Eckford's large pure white.

EMILY HENDERS In. Larye; olonms early and profusely.

MiRS. SANKEy. Large; profuse bloomer.

CupID. The first genuine dwarf sweet pea. Pure white. Pkt. 5c; 1 oz. 25 c.

\section{YELLOW.}

MRS. ECKFORD. Beautifully shaded primrose-yellow. Pkt. 5c; 1 oz. 20c; $1 / 41 \mathrm{~b}$. $40 \mathrm{c} ; 1$ lb. $\$ 1.25$.

PRIMROSE. Pale primrose-yellow.

\section{PINK.}

BLUSHING BeAUTY. Very fine, delicate pink; hooded form.

KATHERINE TRACY. Soft, but brilliant pink.

Mrs. GLADTSONE. A lovely soft pink.

PRima Donna. A most lovely shade of soft pink.

\section{ROSE.}

HER MAJESTY. Bold flowers of a most beautiful rose color.

LADY PENZ INCE. Standard orange pink; wings pure pink.

ODDITy. Peculiar pale carmine and bright rose. Pkt. 5c; 1 oz. $15 \mathrm{c} ; 1 / 41 \mathrm{~b} .30 \mathrm{c}$; 11b. $\$ 1.00$.

OviD. Rose-piak, margined with deeper rose. Pkt. 5c; 1 oz. 15c; 1/4 1b. 30c; 1 lb. $\$ 1.00$.

Miss HUNT. Standard pale carmine salmon; wings soft pink.

\section{SCARLET.}

Carninal. Crimson-scarlet; fine. Pkt. $5 \mathrm{c} ; 1 \mathrm{oz} .15 \mathrm{c} ; 1 / 41 \mathrm{~b} .30 \mathrm{c} ; 1 \mathrm{lb} . \$ 1.00$.

FrRefly. A deep brilliant scarlet; truly a fiery shade. Pkt. 5c; $1 \mathrm{oz} .15 \mathrm{c} ; 1 / 4 \mathrm{lb}$. 30c; 1 lb. $\$ 1.00$.

Princess Victoria. Standard scarlet; wings rosy-mauve.

\section{CRIMSON.}

Duchess of Edinburgh. Scarlet and crimson; small finwers.

MARS. Eikford's new bright crimsun; large and well formed.

\section{BLUISH.}

Captain of tine Blues. Purplish-mauve and pale blue. 


\section{LAVENDER.}

$\$ 1.25$.

Countess of Radnor. Pale mauve, or lavender. Pkt. $5 \mathrm{c} ; 1$ oz. $20 ; 1 / 41 \mathrm{lb} .40 \mathrm{c} ; 1 \mathrm{lb}$.

New Countess. The best new lavender. Pkt. 5c; 1 oz. 20c; 1/4 1b. 40c; 1 lb. \$1.25.

Princess May. Light lavender; flower small. Pkt. 5c; $1 \mathrm{oz} .15 \mathrm{c} ; 1 / 41 \mathrm{lb} .30 \mathrm{c} ; 1 \mathrm{lb} . \$ 1.00$.

\section{MAUVE-REDDISH.}

Dorothy Tennant. Deep, rosy-mauve; beautiful.

\section{MAROON.}

Boreatton. Very dark maroon; self-colored.

Monakch. Deep, bronzy maroon and dark blue.

Stanley. Rich, dark maroon.

\section{MAGENTA.}

Captivation. Beautiful, light magenta, or claret colnr.

\section{BLENDINGS.}

Apple Blossom. Bright rose and pink; beautiful.

BLANCHE FerRy. The popular pink and white.

Butterfly. White laced with lavender; notched standard.

Captain Clark. White and lavender; streaked carmine.

Coquette. Primrose yellow, shaded with pale lavender.

CoUnTESS OF ABERDEEN. Soft pink, turning lighter.

DAYBREAK. Watered crimson-scarlet on white ground.

GAIETY. Lively stripes of bright crimson on white.

Gray Friar. Beautiful watered pnrple on white ground.

LOTTIE ECKFORD. White suffused with lavender-blue.

METEOR. Standard bright orange-salmon; wings pink, veined.

PEACH BLOSSOM. Standard salmon-pink; wings soft pink.

RAMONA. Wnite, daintily splashed with pale pink.

RED RIDING HOOD. Rosy pink; standard overlaps wings. Pkt. 5c; 1 oz. 20c; 1/4 1b. 40 c; 1 lb. $\$ 1.25$.

SENATOR. Bright brown and chocolate striped.

VENUS. Lovely salmon-buff, sbaded rosy pink.

NAMED VARIERIES MIXED. A mixture of the above fine varieties. Pkt. $5 \mathrm{c} ; 1$ oz. 10c; 1/4 1b. 25c; $1 \mathrm{lb}, 75 \mathrm{c}$.

ECKFORD'S HYBRIDS MIXED. Mixed seeds from the best varieties introduced by this celebrated grower. Pkt. 5c; 1 oz. 10c; 1/4 1b. 20c; 1 lb. 60c.

EXTRA MIXED. Large flowered. $1 \mathrm{oz} .10 \mathrm{c} ; 1 / 4 \mathrm{lb} .20 \mathrm{c} ; 1 \mathrm{~b} .60 \mathrm{c}$.

\section{For Sweet Pea Collections, see inside of back cover.}

Pea, Everlasting. Lathyrus latifolius. Hardy perennial climber. Flower similar to Sweet Peas, but not fragrant. WhiTE. Pkt. 10c. MIXED. Pkt. 5c;

Stocks. The Stock, known by some as Gilliflower, has recently been so greatly improved as to be considered almost indispensable for bedding and edgings. Their varied and brilliant colors, profusion of blooms and delicious fragrance render them popular favorites. Hardy annuals, except where noted. MIXED. Pkt. 5c.

TEN WEEKS. Large flowered; dwarf; mixed. Pkt. $5 \mathrm{c}$.

TEN WEEKS. Large flowered. White, Canary Yellow, Crimon, Light Blue, Chestnut, Blood Red; each, per pkt. 10c.

BRompton, or Winter. Mixed. All colors. Pkt. $15 \mathrm{c}$.

EMPERor. Perennia!. Mixed. Pkt. 25c,

Sweet William. Dianthus barbatus. Well-known, remarkably free-flowering plants. The colors are very brilliant, ranging from snow-white to darkest crimson and purple. They emit a very delicate frayrance. Hardy perennial. The seed may be sown as soon as the ground can be prepared. The roots can be divided. Single Mixed. Pkt. 5c.

Double. Mixed. Pkt. 5c. 


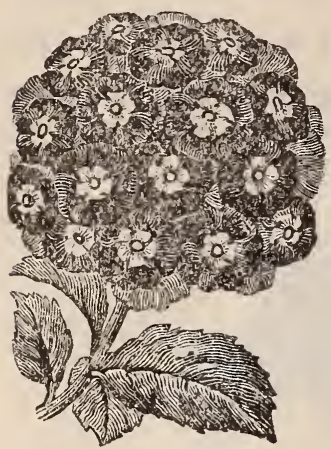

Mammoth Verbena.

Verbena. A well-known and universally popular bedding plant, blooming all summer. Plants s rown from seed are more healthy and make larger and hardier plants than those from cuttings; if sown in spring will flower quite early. Half-hardy perennial. FINE MiXed. Plat. 10c.

Mammoth Candidissima. White. Pkt. 10c.

Manmoth. Extra fine; mixed. Pkt. 10c.

Hybrida Defiance. Fiery scarlet. Pkt. 10c.

Pure White, Striped, Blue Black with White Eye; each, per pkt. 10c.

Violet. Viola odorata. Extremely fragrant, early-blooming low-growing plants. Useful for borders, rock work and bedding. Exceedingly fragrant, a few flowers being sufficient to fill a room with their delicious fragrance. Thrives best in a cool, shady place. Hardy perenuial of easy cultivation. Sweet scented; blue and purple. FINE MIXED. Pkt. 10c.

Wall Flower. Cheiranthus cheri. A well-known, halfhardy perennial, producing spikes of beautiful, exceedingly fragrant flowers. The petals are velvety; the color deep orange shading to brown; rich and handsome. If taken in or protected they will bloom all winter. FinEST DoubLE. Mixed. Pkt. 5c. Single. Large flowered. Mixed. Pkt. 5c.

New ANNUAL. One of the most valuable of recent introductions, flowering the first year from seed. Pkt. 5c.

Zinnia. Large flowering, branching annuals, in bloom the latter part of the season. The flowers are as double as Dahlias, which they resemble, and of as great a variety of rich colors and shades. They can be dried, and will remain fresh in appearance and handsome for winter bouquets. Easily grown and transplanted, and remarkably showy for beds or as a low hedge. Half-hardy annuals. TALI, DoubLE. Mixed. Pkt. 5c.

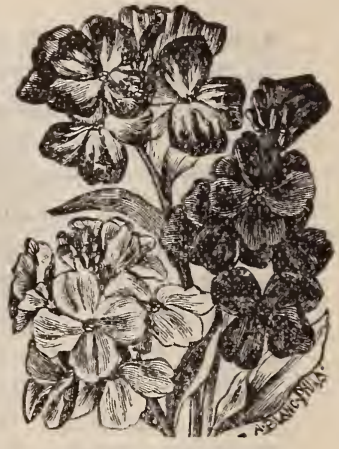

Single Wallflower.

DWARF Double. Mixed. Pkt. 5c.

Ei.egans Grandiflora Plenissima. Very large double flowers. Pkt. 5c.

ZEBra Flowered. Striped and spotted flowers of all shades and colors. Pkt. 5c.

\section{FLOWERING BULBS.}

We are constantly increasing the variety and quantity of the summer flowering bulbs which we handle. Our list of Japanese Lilies is worthy of special attention. It is the most complete assortment ever offered in the Northwest, and we are sure cannot fail to please the lover of handsome flowers. Try a bed of them this year.

Bleeding Heart. Produces freely large racemes of pink and white heart-shaped flowers. Graceful foliage. Each, by mail, 30c.

Caladium Esculentum, or Elephant's Ear. Large size, $4.0 \mathrm{c}$; per doz. $\$ 4.00$. postpaid. Medium size, 30c; per doz. $\$ 3.00$, postpaid.

Cinnamon Vine. A tuberous-rooted climber that grows with great rapidity, quickly covering walls, trellises, etc. Its bright, lively green foliage makes an attractive dense screen. 10c. each, postpaid.

Dahlia, Double. We have these in sereral colors. Order, stating about what color you wish and we will fill it with the resired color, or the nearest to it we can; medium size, each $15 \mathrm{c}$; per doz. $\$ 1.50$, postpaid; large size, each, 20c; per doz. $\$ 2.00$, postpaid.

Cactus Damlia. This new type is the most unique departure in Dahlias. They are very pronounced favorites, because of their remarkably graceful appearance, as they have none of the formality and stiffness so characteristic of the other varieties. Merlium size, each, $15 \mathrm{c}$; per doz. $\$ 1.50$, postpaid. . Large size, each, 20c; per doz. $\$ 2.00$, postpaid. 


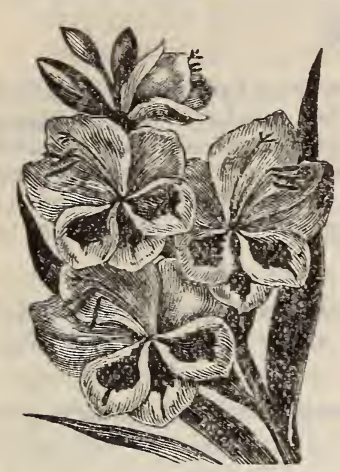

Lemoine Gladiolus.

Gladiolus. A magnificent class of summer flowering bulbs. The colors vary from the most delicate tints to the rich glowing beauty of the orchids and Amaryllis. By planting every two weeks during spring and early summer, a succession of bloom may he had until frost. Easy of cultivation. We have a large stock of mixed varieties, far surpassing in size any that can be obtained from Eastern firms and their coloring and markings are very fine.

PURPLE, YELIOW, LIGHT AND WhITE, large size, each 10c; per doz. $75 \mathrm{c}$; medium size, each $7 \mathrm{c}$ : per doz. 60c; regular size, each 5c; per doz. 40c. Mixed Colors, large size, each $8 c$; per doz. 60 ; medium size, each $5 \mathrm{c}$; per doz. $40 \mathrm{c}$. All postpaid.

Lamotne Varieties Mixed. Each $15 \mathrm{c}$; per doz. $\$ 1.50$ post. paid.

Iily of the Valley. Forcing PIPS; each, 5 c; per doz. 30c; per doz. by mail, 4(ic.

\section{SPECIAL OFFER OF JAPANESE LILIES.}

We have a full line of Japanese lilies, which are catalogued in our fall Bulb List, but we give here most of the leading varieties and quote them while stock lasts at the lowest price we ever made.

These require very jittle care. The principal thing to be attended to is to forbear disturbing them too often. Lilium Aratum cannot bear manure; ordinary light soil suits them best. The L. speciosum are, vext to L. auratum, the most magnificent species. Lilies should be planted deep, not less than six inches. Prices include postage.

AURATUM. Golden-banded lily, large size, each 10c; per doz. $\$ 1.00$.

AURATUM PLATYPHYLLUM (Macranthum), similar to Auratum, but larger flower; each 20c; per doz. $\$ 2.00$.

AURATUM PICTUM. Pure white, with red and yellow band; each 20c; per doz. $\$ 2.00$.

AURATUM VIRGINAL ALBUM. White with yellow band and white spots each $25 \mathrm{c}$; per doz. $\$ 2.50$.

AURATUMI RUBRO-VITTATUM. White with crimson stripe; each $40 \mathrm{c}$; per doz. $\$ 4.00$.

AURATUM IVITTEI. White with yellow band, no spots; each 40c; per doz. $\$ 4.00$.

BATEMANIAE. Bright apricot-tinted; each 10c; per doz. $\$ 1.00$.

BROWVII. Cream inside, purplish outside; each 40c; per doz. $\$+00$.

CONCOLOR VAR. OHIME. Deep scarlet spotted with black; each 10c: per doz. $\$ 1.00$.

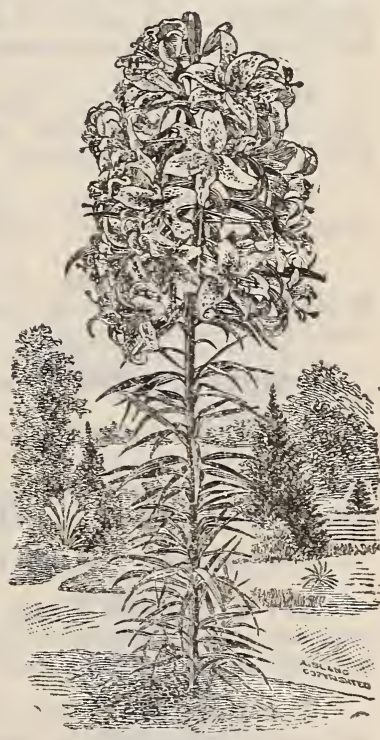

Lilium Auratum

CORDIFOLIUM. White, heart-shaped leaves; each 10c; per doz. \$1.00.

CORIDION VAR OKIHIME. Pure vellow without spots; each 10c; per doz. \$1.00.

El,EGANS. Extra rer; each 8c; per doz. 80c.

ELECIANS ALICE IVILSON. Canary yellow, large; each 40c; per doz. \$4 00 .

ELEGANS ATROSANGUINEUM. Dark blond-red; each 10c: per doz. \$:.0 ).

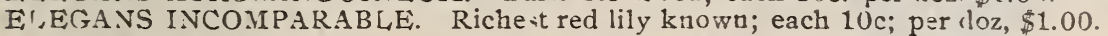

EI,EGANS ORANGE. Very early, orange yellow; each 10c; per doz. \$1.00.

LFICHTLINII. Canary vellow with spots; e tch 15̄c; per duz. $\$ 1.50$.

LEICHTLINII ORANGE RED. Similar to above except color; each 10c; perdoz. $\$ 1.00$.

LONGIFLORUM. Pure white, hest Eister lilv; each 8c; per doz. 80c.

LONGIFLORUM GIGANTEUM. Mammoth size flower; each 10c; per doz. \$1.00.

S'PCIOSUM ALBUM. Purest white; each 10c; per doz $\$ 100$.

SPECIOSUM RURRUM. White with dark rose spots; each 15c; per doz. $\$ 1.50$.

SPECIOSUM RUBRUM MELPOMENE. Rich blood crimson heavily spotted; each $15 \mathrm{c}$; per doz. $\$ 1.50$.

See our Bulb Catalogue issued in the fall. 


\section{FERTILIZERS.}

While the people of Oregon and Washington have in the past been inclined to say that their soils were practically inexhaustible, it has now been proven beyond doubt that on many soils and for many crops the use of commercial fe tilizers brings large returns. and there is now more investigation into fertilizer : of different kinds than ever before. We aim to keep up with the times in supplying what has been proven to be needed, and we offer a number of valuable mixtures, together with the most useful materials for special work. We hope to hear from those who wish to use commercial fertilizers.

Vegetable Fertilizer. This compound is prepared specially for potatoes, vegetables, and gar'en truck, and is unsurpassed for bringing these crops to early maturity. 100 1b. sack, $\$ 2.50$.

Complete Fertilizer. An all around fertilizer for ordinary farm and garden products. 100 lbs. $\$ 2.00$; ton $\$ 35.00$.

Fruit Fertilizer. This excellent fertilizer is mare expressly for fruits. Its use for fruit trees, vines and shrubs of all kinds wiil be followed by a great improvement in the quality and increase in quantity. $100 \mathrm{lb}$. sacks, $\$ 2.25$; ton $\$ 35.00$.

Lawn Fertilizer. For grass lands, lawns and flowers. This article has beet specially prepared to meet the requirements of grass lands, and has been used on a great many lawns in and about this city, with highly satisfactorily results. Do not use barnyard manure on a lawn, for it will fill it full of weeds. This fertilizer will feed the rnots better and bring in no weeds. $25 \mathrm{lb}$. sack, $\$ 1.00 ; 50 \mathrm{lb}$. sack $\$ 150 ; 100 \mathrm{lb}$. sack, $\$ 2.50$.

Hop Fertilizer. This is an excellent manure, and is just the thing needed for the successful growth of hops. A trial will convince hop men of its value. $100 \mathrm{lbs} . \$ 2.00$; 500 lbs. $\$ 8.50$; ton $\$ 33.00$.

Super-Phosphate. This is a first-class article of pure bone phosphate and acts in a remarkably short time. $100 \mathrm{lbs} . \$ 2.50$.

Pure Bone Meal. We supply pure bone meal, finely ground, for use on crops of all kinds. Anim $t l$ bone is a most valuable enricher of the soil and a crop-producer, and is sure to pay well when used. 100 lbs. $\$ 1.50$; ton $\$ 25.00$.

Grannlated Bone. For chickens. $100 \mathrm{lbs}$ \$1.50.

For larger quantities of any of these fertilizers, write for special quotations.

\section{DIRECTIONS FOR USING.}

For Grass. Use 300 to 350 pounds to the acre. Apply broadcast before a rain.

For Vines and Fruit Trees of Every Kind. Loosen the earth about the vine or tree, and use at the rate of 500 lbs. to the acre, working it into the soil; or, when setting, put into the hole from a handful to a shovelful, according to the size of the tree or vine.

For Potatoes. Mix the fertilizer with the earth where the seed is dropped. Use at the rate of $\$ 00$ pounds to the acre.

For Corn or Vegetables. Use from 300 to 800 pounds to the acre, thoroughly mixed in:o the soil at the time of sowing the seed.

For Hops. Use from 400 to 500 pounds to the acre.

A light top dressing of these fertilizers, applied at any time, will be found to aid the growth of crops very materially.

\section{OTHER FERTILIZERS.}

Land Plaster. Sacks of about 100 lbs. 75 c.

Jadoo Finre. This is a potting material rather than a fertilizer and is manufactured by boiling into peat moss certain chemicals which contain the elements neces:ary to support plint life. [t holils its streugth for a long time an $l$ after a year or $t(w)$ cau be renewed by the application of Jadoo Liquid. Very fiae for house plants. 1 1b. 10 ; 5 lbs. $40 \mathrm{c}$; 10 lbs. $70 \mathrm{c}$. 
Nitrate of Soda. $\$ 3.50$ per 100 lbs.

Fish Guano. 3c per lb; $\$ 1.75$ per 100 pounds.

Bowker's Plant Food. Best Fertilizer for house plants. $1 / 2-1 b$. package 25c; 1-1b. package 5uc, postpaid.

\section{POTASH.}

In recent years, the use of Potash has aroused an increasing interest in the minds of progressive farmers and those who conduct the agricultural experiment stations in the various states. By practical experiments it has been proven that potash fertilization has been followed by an enormously increased yield and great improvement in the quality as well as in the size of fruits, grains and furage plants. Aiso kainit has been found to be very effective in de-troying many insect pests that infest the roots of fruit trees, bushes and vines. Every farmer should find out by practical experiment what his soil needs and avail himself of the large profit to be derived from the use of potash and other commercial fertilizers. We have a large stock of Potash Salts, direct from the mines at Stassfurt, Germany, and are in position to furnish them at reasonable prices. We have numbers of pamphlets published on the subject of Potash, and should be pleased to furnish them on application to anyone who wishes to investigate the matter.

Muriate of Potash. 21/2c. per 1b; sack, 224 lbs. $\$ 6.25$.

Sulphate of Potash. 33/4c. per 1b; sack, 224 1bs. $\$ 7.00$.

Kainit. $1 \frac{1}{2}$ c. per $1 b$; sack, 224 lbs. $\$ 2.25$.

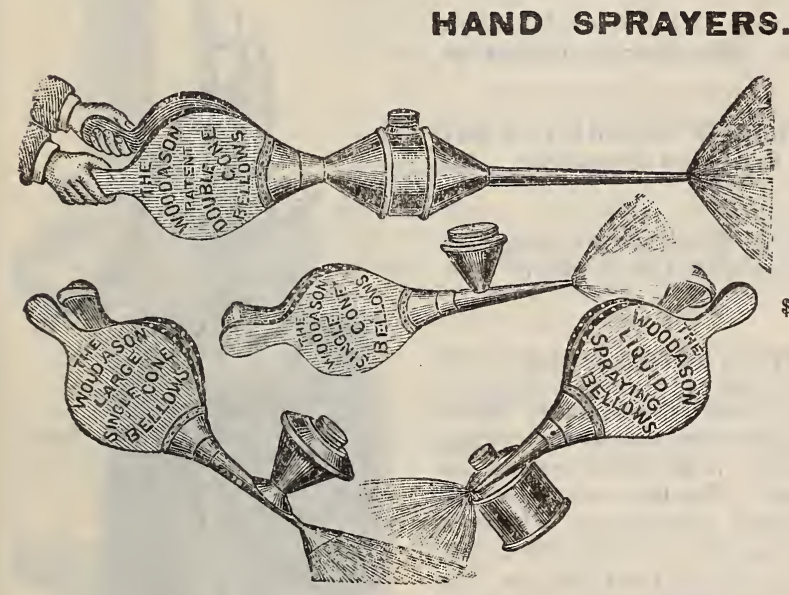

Sprayers, Woodason's Liquid, like cut, $\$ 1.50$ and $\$ 2.00$.

Powder Bellows, Woodason,s Single Cone, $\$ 1.15$.

Powder Bellows, Woodason's, Large Single Cone, $\$ 2.00$

Powder Bellows, Woodason's, Double Cone, $\$ 3.00$.

The Woodasion should not be confounded with the inferior bellows now being put on the market by some firms. Of these cheaper makes we offer the Small Liquid Sprayer at $\$ 1.00$ and the Large Liquid Sprayer at 1.35 .

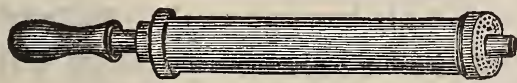

Brass Syringes for Spraying.

Length of barrel, 6 inches, $\$ 1.00$; by mail, $\$ 1.05$.

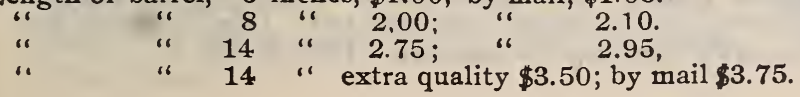

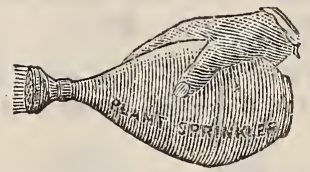

Scollay Sprayer.

Four sizes -50 c. $75 \mathrm{c}$. $\$ 1.00$ and $\$ 1.25$; by mail, 55c. 85 c. $\$ 1.10$ and 1.35 .

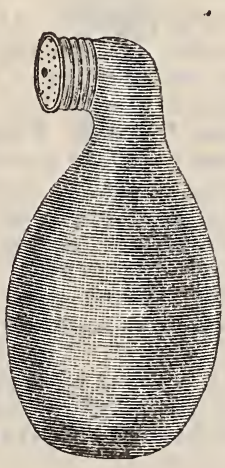

Perfection Sprayer.

No. 1 Angle Neck, 60c; by mail, $65 \mathrm{c}$.

No. 3, Angle Neck, 85 c; by mail, 95 c. 


\section{SPRAYING PUMPS.}

Now that spraying has come to be recognized as a necessity, one of the first and most escential things for an orchardist to have is a good spray pump, one that will handle the different washes aud sprays to be used in his orchard in the most effective and ecouvmical manner.

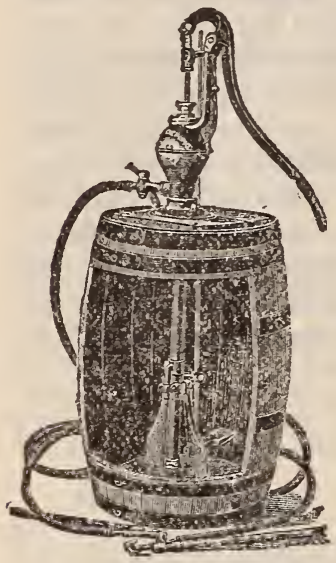

No. 550 .

We offer this season one of the best pumps manufactured. Its $\mathbf{N e w} \Delta$ gitator is comparatively and superlatively better than any return stream agitator and the very best one of any kind that we have ever seen. We call this the agitator, hecause no oth $r$ does equally good work. Without an efficient Agitator, the nozzles, the valres and the suction strainer may clog up and cause the pump to work hard. Have we said enough? Buy a spray pump with New Agitator and you will say, "No!" Try it and decide for yourself.

The Orchard Spray Pump shown by the above cut is a first class orchard sprayer. It has adjustable attachment or base to fit the top or side of any barrel. The outfit can be placed on a wagon and mored about at will. The Air Chamber is large and insures a constant stream; the pump swings on its base, where it can be fastened in any position. A suction strainer is furnished. The Working Parts are made of brass; the cylinder being brass lined, the piston rod brass cased, and the plunger and valves solid brass. The Discharge is provided with Double Y connection, so that one or two sections of hose may be u-ed at will. A tight cap is provided for one of the discharge openings.

OUTFIT B. Fig. 550 Spray Pump with 5 feet of $1 / 2$ inch 3-ply hose, with one spray nozzle. Has Double Discharge Y without barrel. $\$ 8.00$.

OUTFIT B. B. The same as Outfit B, but with $12 \frac{1}{2}$ feet instead of 5 feet of hose; and 8 feet pipe extension. No barrel. $\$ 9.50$.

OUTFIT D. The same as Outfit $B$, with extra large air chamber and 8 foot pipe extension with Globe valre. No barrel. $\$ 12.50$.

The "Peerless." An all Brass Spray Pump is the most durable, particularly, if use 1 for applying the fungicides such as "Bordeaux Mixture" and Ammoniacal Solution of Copper Carbonate. Brass prevents corrosion. The "Peerless" Spray Pump fulfills these requirements, as all working parts are male of brass. The large air chamber is also brass, as well as the discharge conrection, which is provided with a three-way stop cock for shutting off either or both sectiuns of hose at will. A cap is provided for one of the discharge npenings where only one section of hose is used. The Frame and Base are combined in one rigid casting, which is so constructed that it will fit either the top or side of a barrel. The New Swivel Lever enables the operator to work with either the right or left hand, without changing his position-a novel and convenient feature. The Mechanical Agitator is used on this pump.

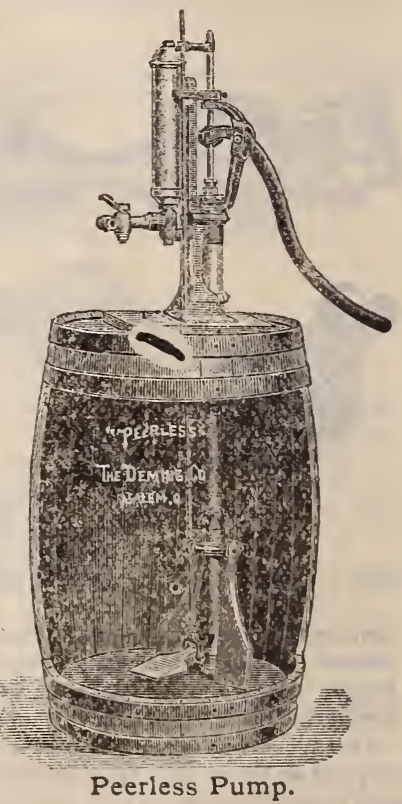

OUTFIT B. Pump with 5 feet of $1 / 2$ inch 3-ply hose and nozzle. No barrel. $\$ 12.00$.

OUTFIT B. B. Pump with $121 / 2$ feet of $1 / 2$ inch 3 ply hose and nozzle, with pole connection and 8 foot pipe extension with Globe valve. No barrel. $\$ 14.00$.

The Success Bucket Spray Pump. This pump has brass working parts and air chamber, indestructible bronze valves ant malleable iron foot rest. Complete with Bordeaux nozzle, packed in neat box, with directions for spraying. Price $\$ 5.00$. 


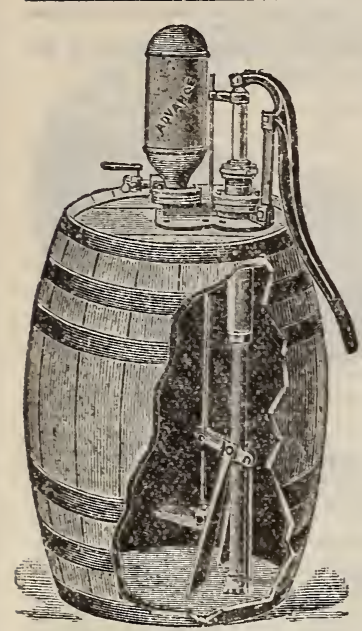

"Advance" Pump.

The "Advance." This pump bas brass tube cylinder, brass valves, and hollow differential plunger of brass tubing, which, in connection with the large air chamber, gives a steady stream, eren with heavy work. This pump has a $2 \frac{1}{2}$-inch cylinder and 5 inch stroke. The discharge opening is provided with a double $Y$ or 3-way stop cock, thus adapting it for two sections of hose. The Mechanical Agitator is used on "Advance" Pumps.

"Advance" Pump, as shown in cut, with brass double $Y$ connection, with cap, having stop cock, $12 \mathrm{l} / 2$ feet hose, 8-fnot Pipe Extension with Globe Valve and nozzle. $\$ 15.00$.

The Prize Knapsack Pump. A good brass pump, so arranged in a galvanized iron tank as to make a firstclass knapsack pump. Can also be used as a bucket sprayer. This outfit is also provided with a handle at the top of the tank, with which it can be readily carried from place to place. Price, $\$ 7.50$.

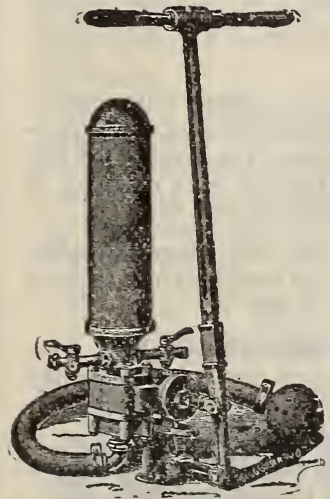

Planet Pump.

The Planet Pump. A powerful punip for spraying large orchards. Arranged for one, two, three or four lines of

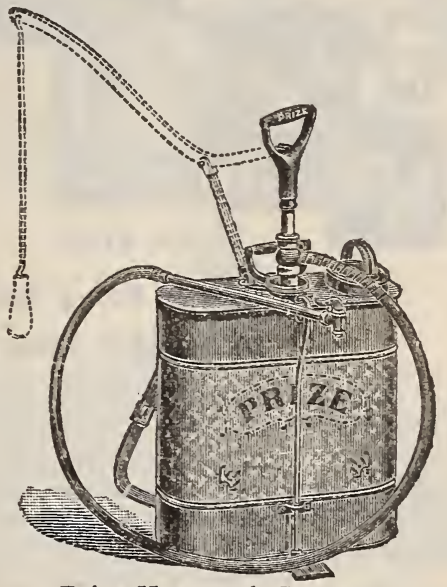

Prize Knapsack Pump. hose. The cylinder is lined with heavy brass, and the pump is supplied with four feet of wire-lined suction hose and brass globe strainer.

No. 1, Pump only, $\$ 25.00$.

No. 1, with 50 feet 4-ply hose, two pipe extensions with globe valves, two nozzles and four feet suction hose, $\$ 34.00$.

The Double Discharge Attachment. Fig 366 . Used on Barrel Spray Pumps, for opening or closing at will either or both discharges is represented by the accopmanying cut. Price $\$ 1.75$.

A Double Spraying Attachment, (Fig. 980) combined $\mathrm{u}$ ith pole connection, is represented by the following cut. Price, $75 \mathrm{c}$.

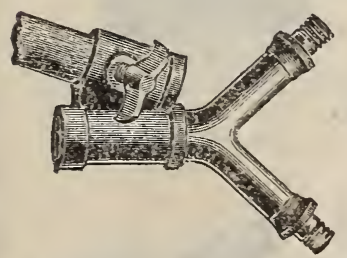

Fig. 980.-Double Spraying Attachment. $\$ 1.25$.

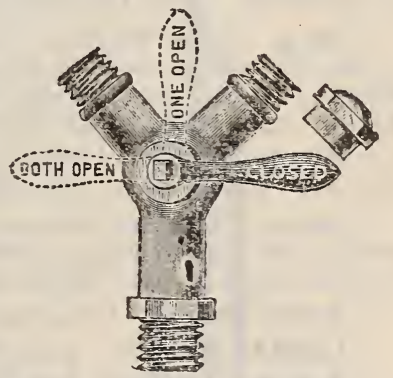

Fig. 366-Brass Discharge Connection with 3-way Cock.

Bamboo Extensions. 8-foot lengths, $\$ 1.00$; 10 -foot

Pipe Extensions. 8-foot, with fittings, 50c; same with globe valve, $\$ 1.25$.

Best quality Hose, for Spray Pumps, 3-ply, $1 / 2$ inch, 12c. per $\mathrm{ft} ; 3 / 4$ inch $15 \mathrm{c}$. per $\mathrm{ft} ; 4 \cdot \mathrm{ply}, 1 / 2$ inch, $15 \mathrm{c}$. per $\mathrm{ft} ; 3 / 4$ inch, 20c. per fout.

Other grades of Hose from 5c. to 18c. per foot.

Vermorel Nozzle....................\$.75

Bordeaux Nozzle........................ 1.00

Improved Cyclone Nozzle. . . . . . . . . . . . 1.00

Bean Crclone Nozzle .................. 1.00

Bean Duck-Bill Nozzle.................. 1.00

Hop Nozzle..................... 1.50

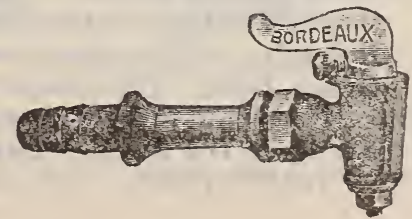


Brass Bucket Spray Pump. A first-class pump for spraying small trees and for light work in general. Price, $\$ 3.00$.

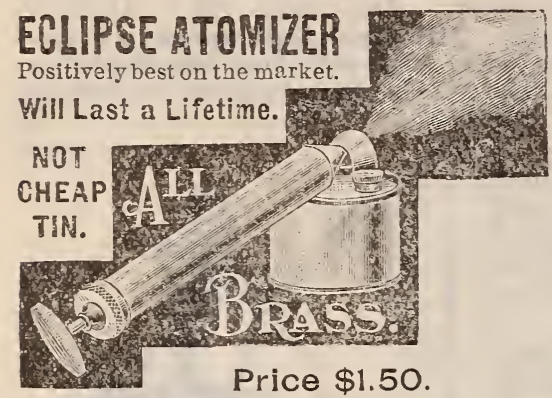

Smith's Patent Force Pump. Tin; three nozzles, $\$ 1.00$.

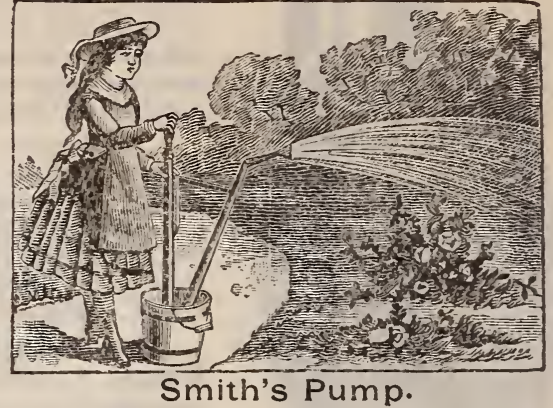

\section{WASHES FOR DESTROYINC INSECTS, ETC.}

We give below a list of washes recommended by the State Board of Horticulture for destroying insect pests on trees, etc; also other washes and ingredients for same use.

No. r. Winter Spray for San Jose Scale and Peach Curl Leaf. Ingredients-salt, lime, sulphur, etc. For winter, use $1 \mathrm{lb}$. to 2 gal. water; for summer, $1 \mathrm{lb}$. to 8 gal. water. Apply warm just before buds swell in the spring. $1 \mathrm{lb}$. $10 \mathrm{c}$; case 25 to $50 \mathrm{lbs}$. $5 \mathrm{c}$ per $1 \mathrm{~b}$; $160 \mathrm{lb}$. case $4 \mathrm{c}$ per $1 \mathrm{~b}$.

No. 2. For San Jose Scale and Wooly Aphis. Ingredients-sulphur, lime, blue vitriol. For winter, use $1 \mathrm{lb}$. to $2 \frac{1}{2}$ gal. hot water and apply just before buds swel; for a preventive, $1 \mathrm{lb}$. to 5 or 6 gals. water; for summer, $11 \mathrm{~b}$. to 8 or 10 gals. water. For Codlin Moth, add to 8 or 10 gals. of solution a full $1 / 20 \%$. Paris Green or London Purple, first making a paste with water. $1 \mathrm{lb}$. 10c; case 25 to $50 \mathrm{lbs}$. $5 \mathrm{c}$ per 1b; case $160 \mathrm{lbs}$. 1c per 1b.

No. 3. Summer Spray for San Jose Scale. Ingredients-whale oil soap, sulphur, caustic suda, commercial potash. $11 \mathrm{~b}$. to 5 gal. hot water. Apply at almost 130 degrees in the vessel. $1 \mathrm{lb} .10 \mathrm{c}$; case 25 to $50 \mathrm{lbs}$. $7 \mathrm{c}$ per lb.; case $160 \mathrm{lbs} .5 \mathrm{c}$ per $1 \mathrm{~b}$.

No 4. Resin Wash for Green and Wooly Aphis. A good summer spray for San Jose Scale. Ingredients-Resin, salsoda. For Hop Louse, use $1 \mathrm{lb}$. to $9 \mathrm{~g} t \mathrm{ls}$. water; for Woolly Aphis, 1 1b. to 7 gals. water; for San Jose Scale, $1 \mathrm{lb}$. to 6 gals. water. Apply cold or lukewarm. $1 \mathrm{lb}$. $10 \mathrm{c}$; case 25 to $50 \mathrm{lbs}$. $7 \mathrm{c}$ per lb.; case $160 \mathrm{lbs}$. $5 \mathrm{c}$ per $1 \mathrm{~b}$.

No. 5. Whale Oil Soap. Summer Spray for Hop Louse and Green Aphis. Use $1 \mathrm{lb}$. to 7 gals. water. $1 \mathrm{lb}$. $10 \mathrm{c}$; case 25 to $50 \mathrm{lbs} .5 \mathrm{l} / 2 \mathrm{c}$ per $1 \mathrm{~b}$; ; case $160 \mathrm{lbs} .5 \mathrm{c}$ per $1 \mathrm{~b}$.

No. 7. Bordeaux Mixture for Fungi. Ingredients-Sulphate of copper, lime. For winter, use $1 \mathrm{lb}$. to 2 gals. water; for summer, $1 \mathrm{lb}$. to 4 gals. water. $1 \mathrm{lb}$. $10 \mathrm{c}$; case 25 to 50 lbs. $7 \mathrm{c}$ per $1 \mathrm{~b}$; case $160 \mathrm{lbs}$. $5 \mathrm{c}$ per $1 \mathrm{~b}$.

Paris Green. $\quad 1 / 2 \mathrm{lb}$. can 25c; $1 \mathrm{lb}$. can $40 \mathrm{c} ; 5 \mathrm{lb}$. can $\$ 1.50$.

London Purple. 1 lb. $25 \mathrm{c}$; 5 lbs. $\$ 1.00$.

Rosin. 1 lb. $10 \mathrm{c} ; 100$ lbs. $\$ 4.00$.

Sulphur. 1 lb. $10 \mathrm{c} ; 10$ lbs. 30c.

Babbitt's Iye. 10c. per can.

Sulphate of Copper. $1 \mathrm{lb} .10 \mathrm{c} ; 10 \mathrm{lbs} .60 \mathrm{c} ; 100 \mathrm{lbs} . \$ 5.00$.

Quassia Chips. $1 \mathrm{lb} .10 \mathrm{c} ; 10 \mathrm{lbs}$. or more, $7 \mathrm{c}$. per $1 \mathrm{~b}$.

Lime. Per barrel, $\$ 1.35$.

\section{INSECTICIDES.}

Slug Shot. A special insect destroyer in powder form. Kills all kinds of bugs that trouble an ordinary garden. $1 \mathrm{lb} .15 \mathrm{c} ; 5 \mathrm{lb}$. pkg. $50 \mathrm{c}$.

Ongerth's Insecticide. An insecticide more concentrated than the above. $1 \mathrm{lb} .25 \mathrm{c}$.

Buhach. A Pyrenthrum preparation of good strength. $1 \mathrm{oz} .10 \mathrm{c} ; 1 / 41 \mathrm{~b} .25 \mathrm{c} ; 1 \mathrm{lb} .75 \mathrm{c}$.

Grape Dust. This powder will positively destroy Mildew. If your Roses, Grapes or plants are troubled with this disease you can rid them of it. $11 \mathrm{~b} .15 \mathrm{c} ; 5 \mathrm{lb}$. pkg. $50 \mathrm{c}$.

Fir Tree Oil Soap. The best thing we know of for killing Green Aphis on shrubbery and garden plants. $1 / 2 \mathrm{lb}$. can $30 \mathrm{c}$; by mail $40 \mathrm{c}$. 


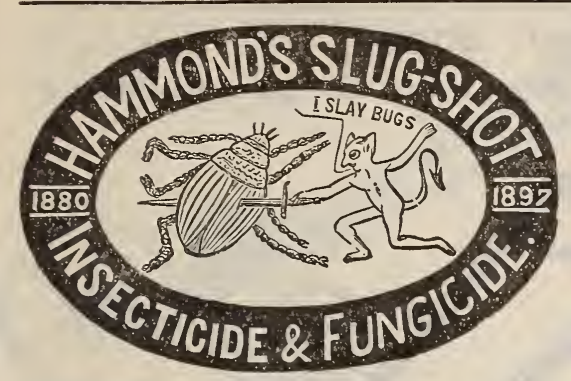

Hammond's Slug Shot. Excellent for destroying cabbage, turnip and beet fly, potato bugs, currant worms, green aphis, etc. Prepared ready for use, 1 lb., 15c; 5-1b. pkg. $50 \mathrm{c}$.

Hammond's Grape Dust. For the prevention of mildew on roses, grapes, gooseberries, etc. It is not only a preventive, but it cures plants already affected. Our experience with it has been that it is effective where snch remedies as powdered sulphur have completely failed. Apply with bellows. 1 lb. 15c; 5-1b. pkg. 50c.

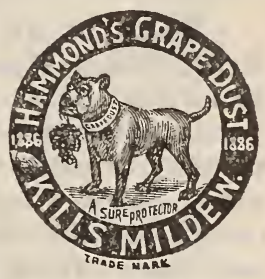

Palmer's Plant-Bed Mats. Frost-proof. Made expresslv for winter covering of hot-beds, cold frames, plants and seeds of all kinds. Indestructible, cheap and warm; will not harbor mice or vermin; easily handled; dry out quickly after rain.

No.1. Burlap Cloth, filled with combination wool and quilted, seams three inches apart, and edges firmly buund. $4.0 \times 76$ inches, $\$ 1.00$ each. $76 \times 76$ inches, $\$ 1.25$ each.

No. 2. Duck Cloth, outside, filled and quilted same as No. $1.40 \times 76$ inches, $\$ 1.25$ each; $76 \times 76$ inches, $\$ 1.50$ each.

No. 3. Waterproof. Made of oil duck, filled and quilted the same as No. 1. $40 \times 76$ inches, $\$ 1.50$ each; $76 \times 76$ inches, $\$ 1.75$ each.

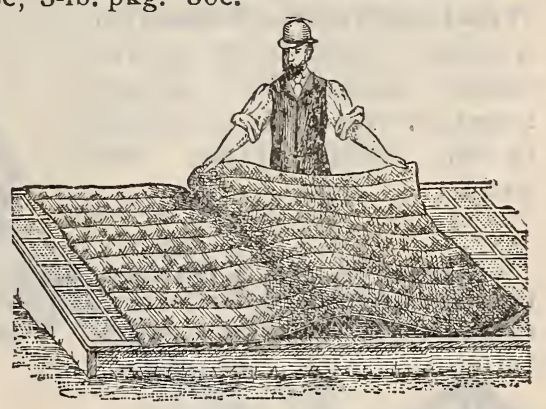

Plant-Bed Mats.

Plant-Protecting Cloth. This cloth is useful for protecting plants from frosts and for covering hot-beds a ud frames, instead of glass. Specially prepared to prevent mildewing and rotting.

Light grade, per yard, $10 \mathrm{c}$; per piece of 68 yards $\$ 5.50$

Medium " " " $15 \mathrm{c} ;$ " “ 62 " 6.00

\section{GARDEN TOOLS AND IMPLEMENTS.}

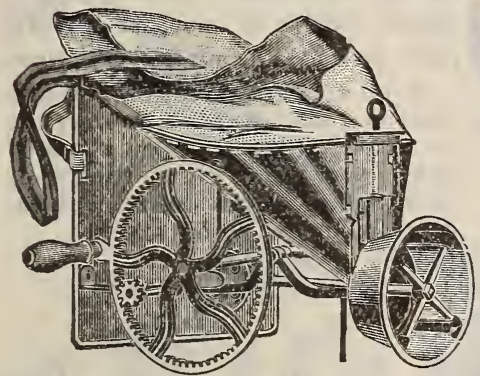

Cahoon Hand Seeder.

\section{Cahoon Hand} Seeder. Price $\$ 3.75$.

Granger Hand Seeder. Price $\$ 3.50$.

Diamond Hand Cu1tivator. A strong, light tool, which will do a great variety of wori and is offered at a very low price.

Single Wheel "Diamond" $\$+.00$.

Double Wheel "Diamond" $\$ 5.00$.

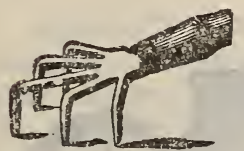

Excels'r Weeders, 20c Noyes' Hand " $30 \mathrm{c}$ Hazeltine's " $30 \mathrm{c}$ Combination " $30 \mathrm{c}$

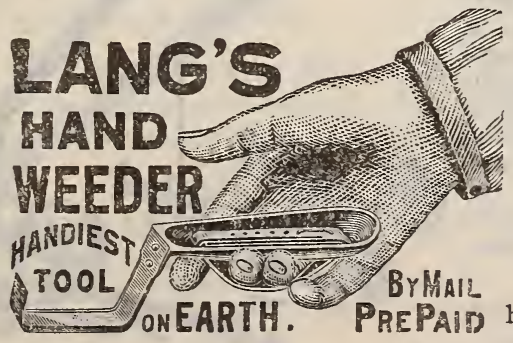

ONEARTH.

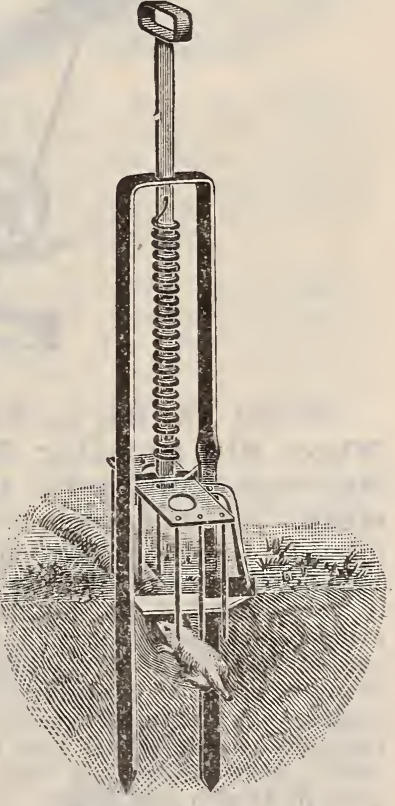

Reddick Mole Trap.

The best cheap Mole Trap"we have ever offered. Price $\$ 1.00$. 


\section{"PLANET JUNIOR" GOODS.}

We list the most popular of the Planet Jr. tools. For full description see Planet Jr. Catalogue, which will be mailed on application.

Planet Jr. No. I Combined Drill, Wheel Hoe, Cultivator and Plow. This tool is the most popular Combined Garden Tool known. As a Drill it is similar to and as carefully made as No. 2 , though somewhat smaller, holding one quart. As a Wheel Hoe, Wheel Cultivator or Wheel Plow it is nearly equal to the tools described below. Each machine is sent out with all the tools shown in cut. Weight 4.7 lbs. Price $\$ 9.50$.

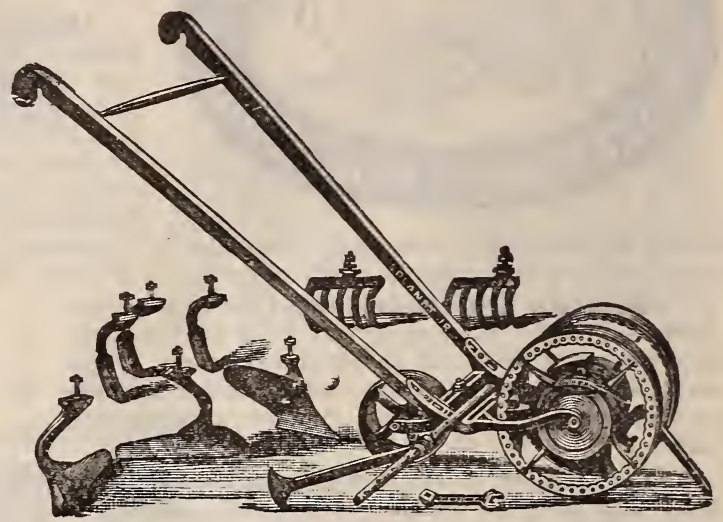

Planet Jr. No. 2 Garden Drill. This is a simple and accurate drill and has been the standard machine for years. It holds $2 \frac{1}{2}$ quarts. It sows all garden seeds accurately at any desired thickness or depth. Weight $40 \mathrm{lbs}$. Price $\$ 7.00$.

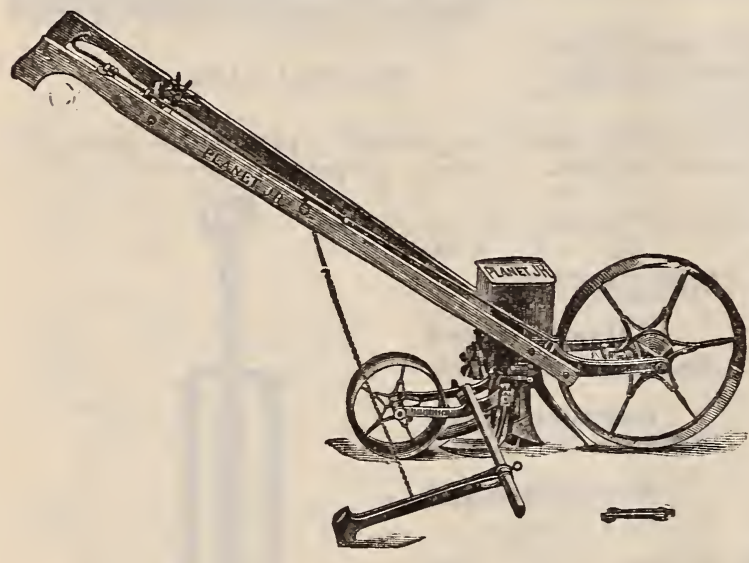

Planet Jr. No. 3, Single Wheel Hill Dropping Drill. This is one of the newer machines and large numbers of practical men have used them since 1896 . It holds two and one-half quarts and sows all kinds of garden seed with the greatest regularity. It opens the furrows, drops either in hills or drills at pleasure: covers, rolls down and marks the next row, all at one operation. When used as a hill dropper, it may be so arranged as to plant the seed either four, six, eight, twelve or twenty-four inches apart. Weight, 49 lbs. Price, $\$ 9.50$.

Planet Jr. No. 4, Single Wheel Hill Dropping Drill, Hoe and Cultivator, Combined. We are pleased to offer this year a new combined tool of such excellence that we can scarcely recommend it too highly. It combines conveniently in a single garden implement a capital hilldropping and a continuous row seeder, with the most perfect and complete single-wheel hoe, cultivator, rake and plow that the most particular can desire. Holds 2 quarts. Weight, 45 lbs. Price, $\$ 10.50$.

The same machine, with drill only, weight $37 \mathrm{lbs}$., for $\$ 7.50$.

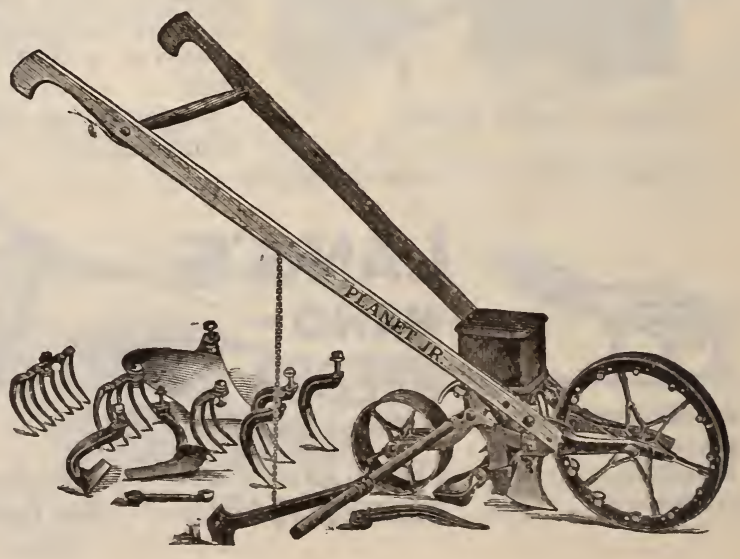




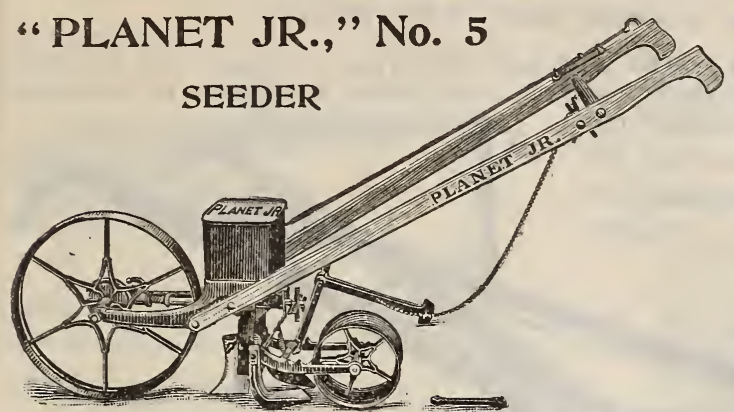

The Planet Jr. No. 5 Seeder is similar to No. 4 without attachments, but of larger capacity, holding 4 quarts. Price, $\$ 12.50$.

Planet Jr. Fertilizer, Pea and Bean Drill. Price, $\$ 13.50$. The same tool when arranged with Opening Plow, Coverer, Roller and Marker. Price, $\$ 16.50$.

The Planet Jr. No. ro, Double Wheel Hoe Cultivator and Plow. The popular old double wheel hoe. Price, $\$ 6.50$.

Planet Junior No. rI Double Wheel Hoe, Cultivator, Rake and Plow. This implement has 11 -inch wheels which may be set at four different distances a part, and the frame may he set at three different heights without disturbing the handles or removing the nuts from the standards. It has seven pairs of tools, being similar in every respect to No. 12 except that it has an extra pair of hoes and two pairs of rakes. See cut of No. 12 for illustration. Price, $\$ 8.50$.

Planet Junior No. I2, Double Wheel Hoe, Cultivator and Plow. Identical with No. 11, except that it has fewer tools as shown in the cut. Price, $\$ 6.50$.

Planet Jr. No. I3, Double Wheel Hoe. This is the No.11, with a pair of 6-inch hoes only. The other tools may be added as wanted to either No. 12 or No. 13. Price, \$4.50.

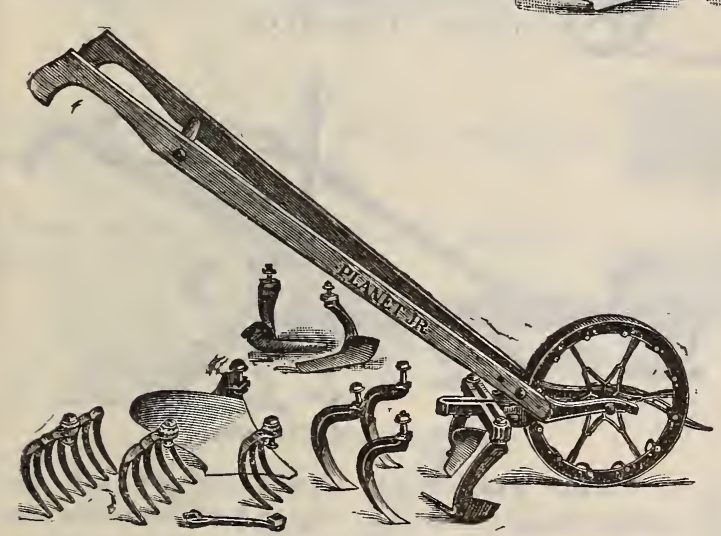

Planet Jr. No. 15, Single Wheel Hoe.

Planet Jr. No. I8, Single Wheel Hoe. The same as No. 15 but with one pair 6-inch hoes only. The other tools may be added as wanted to No's. 16, 17 and 18. Price, $\$ 3.50$.

Pire F1y Single Wheel Hoe. Price, $\$ 4.25$.

Fire F1y Hand Plow. Invaluable for small gardens. Price $\$ 2.50$.

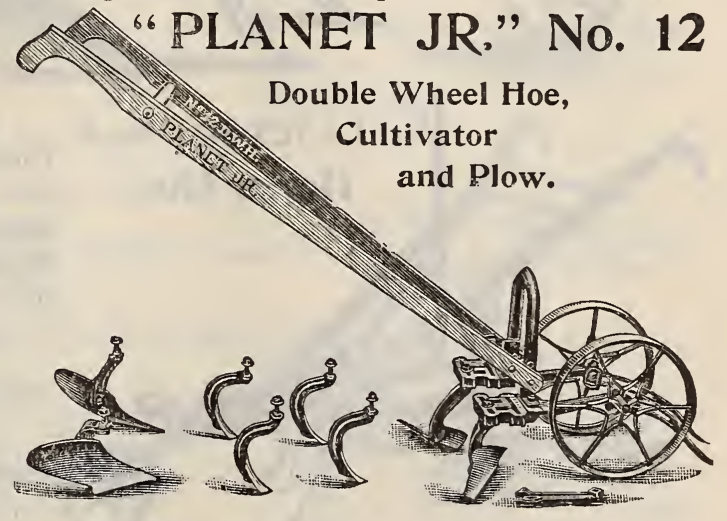

Planet Jr. No. I5, Single Whee1 Hoe, Cultivator, Rake and Plow. The latest and best Single Wheel Hoe in every particular, having all the tools shown in the cut. Price, $\$ 6.50$.

Planet Jr. No. I6, single Wheel Hoe, Cultivator, Rake and Plow. The same as No. 15 except that it does not have the pair of shield hoes and the wide rake. Price, $\$ 5.50$.

Planet Jr. No. I7, single Wheel Hoe, Cultivator and Plow. The same as No. 16 but without the rakes. Price, $\$ 4.50$.

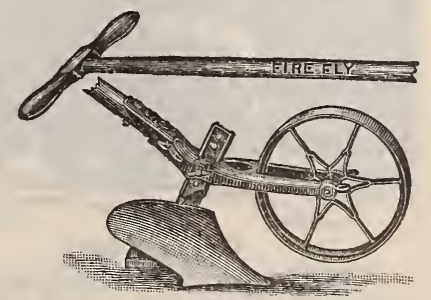

Fire Fly Hand Plow. 
Planet Jr. No. 5 Horse Hoe, common wheel. Price, \$7.25.

Planet Jr. No. 6, Combined Horse Hoe and Cultivator is widely and favorably known. Chief among the late improvements are the Lever Wheel, a necessity for particular work; Patent Lever Expander, changing the width instantly; and Handle Adjustment for height, and also sidewise for use in grapes, pole beans, blackberries, nursery stock, etc., and when corering. Price, $\$ 7.50$.
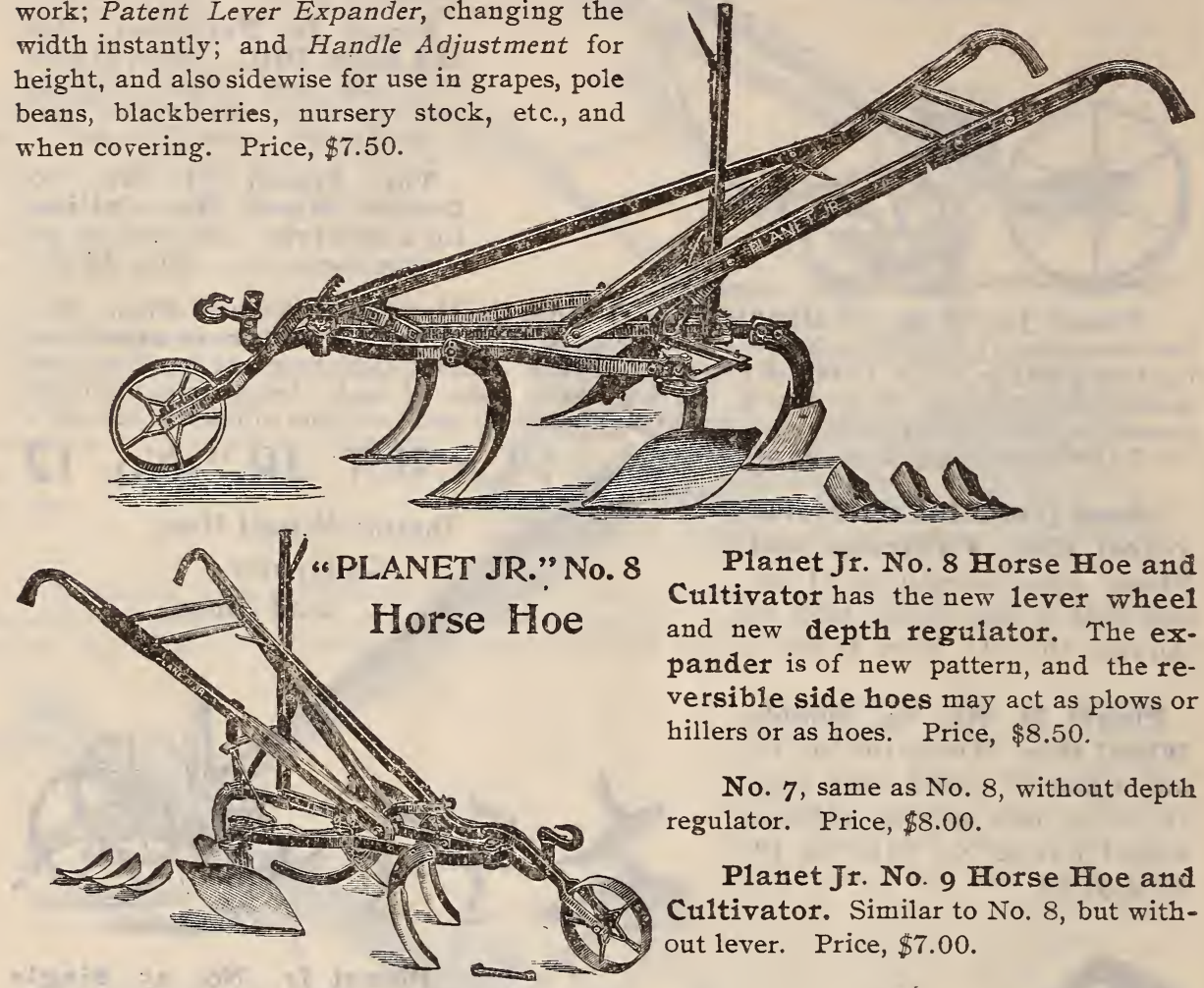

Planet Jr. No. 8 Horse Hoe and Cultivator has the new lever wheel and new depth regulator. The expander is of new pattern, and the reversible side hoes may act as plows or hillers or as hoes. Price, $\$ 8.50$.

No. 7, same as No. 8, without depth regulator. Price, $\$ 8.00$.

Planet Jr. No. 9 Horse Hoe and Cultivator. Similar to No. 8 , but without lever. Price, $\$ 7.00$.

Planet Jr. Harrow and Cultivator, with foot-lever pulverizer, complete. Price, $\$ 8.50$.

The same tool with wheel, price, 7.25 .

The same, plain, price, $\$ 6.00$.
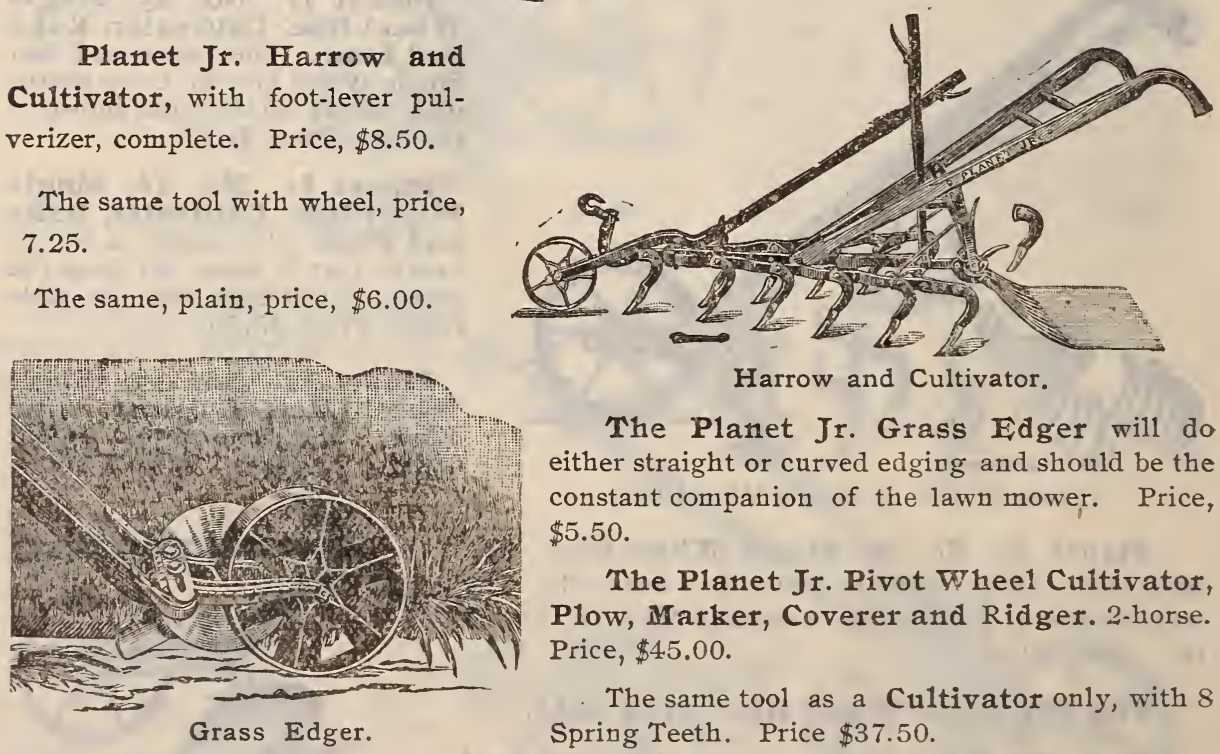

Harrow and Cultivator.

The Planet Jr. Grass Edger will do either straight or curved edging and should be the constant companion of the lawn mower. Price, $\$ 5.50$.

The Planet Jr. Pivot heel Cultivator, Plow, Marker, Coverer and Ridger. 2-horse. Price, $\$ 45.00$.

The same tool as a Cultivator only, with 8 Spring Teeth. Price $\$ 37.50$.

For additional descriptions of preceding tools or for descriptions of other styles, see Planet Ir. Catalogue, which will be mailed on application. 


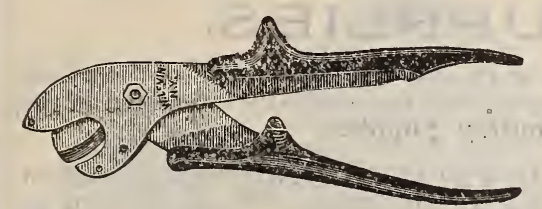

The Levin Pruner. Very strong and an easy cutter.

No. 23, 3/4 inch cut. Post paid, 75c.

No. 24, 1 inch cut. Post paid, $\$ 1.00$

No. 5, "Sheep Toe Clipper," fine shear for light pruning, as roses, etc. $40 \mathrm{c}$; by mail, $55 \mathrm{c}$.

"No. I4," Spiral Spring, 50c; by mail, 65c.

"No. 2I," Straight Springs, 55c; by mail, 70c.
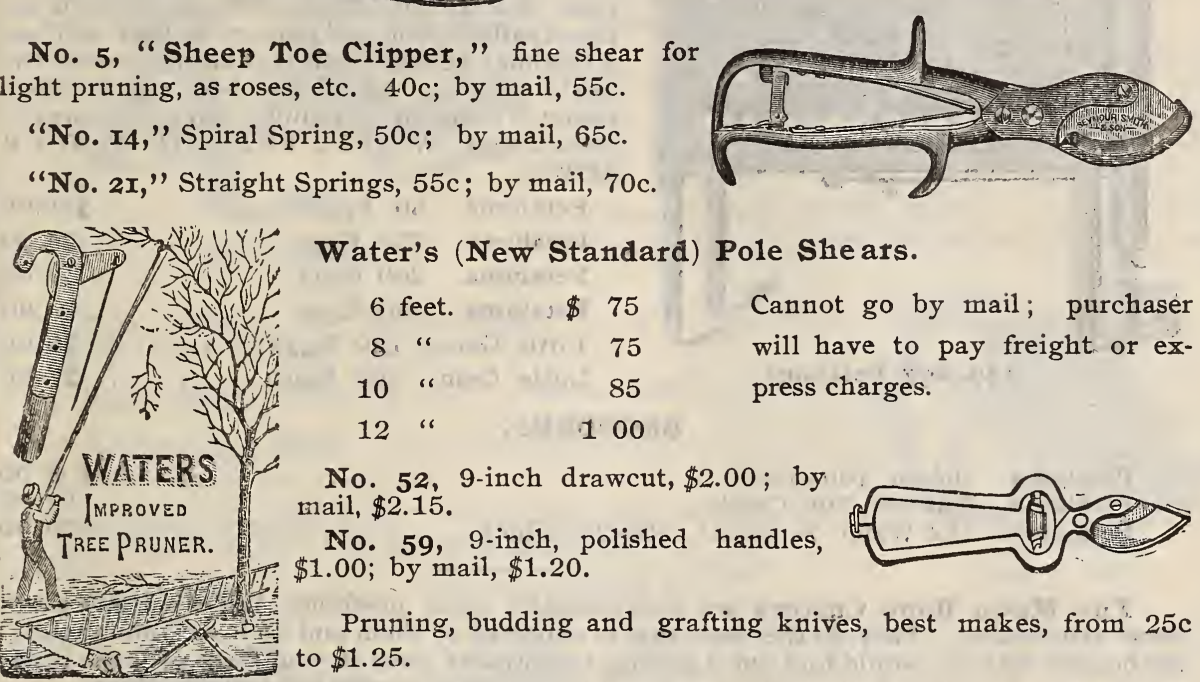

Water's (New Standard) Pole Shears.

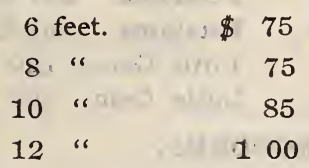

Cannot go by mail; purchaser will have to pay freight or express charges.

No. 52, 9-inch drawcut, $\$ 2.00$; by mail, $\$ 2.15$.

No. 59, 9-inch, polished handles, $\$ 1.00$; by mail, $\$ 1.20$.

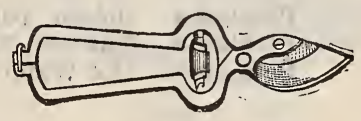

Pruning, budding and grafting knives, best makes, from 25c to $\$ 1.25$.

Pruning Saws, California, 12 inch, Crescent,................... 70

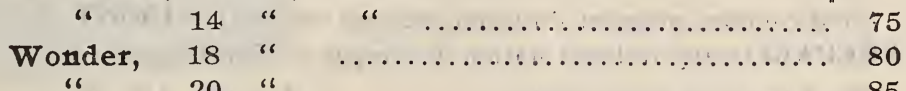

" 20 " $\quad 20 \ldots \ldots \ldots \ldots \ldots \ldots \ldots \ldots \ldots, 85$

Two Hand Branch Shear, Rockdale. 41 inch, $\$ 1.10,26$ inch, 85c.

Two Hand Branch Shear, Buckeye. 28 inch, $\$ 1.25 ; 24$ inch 85 c.
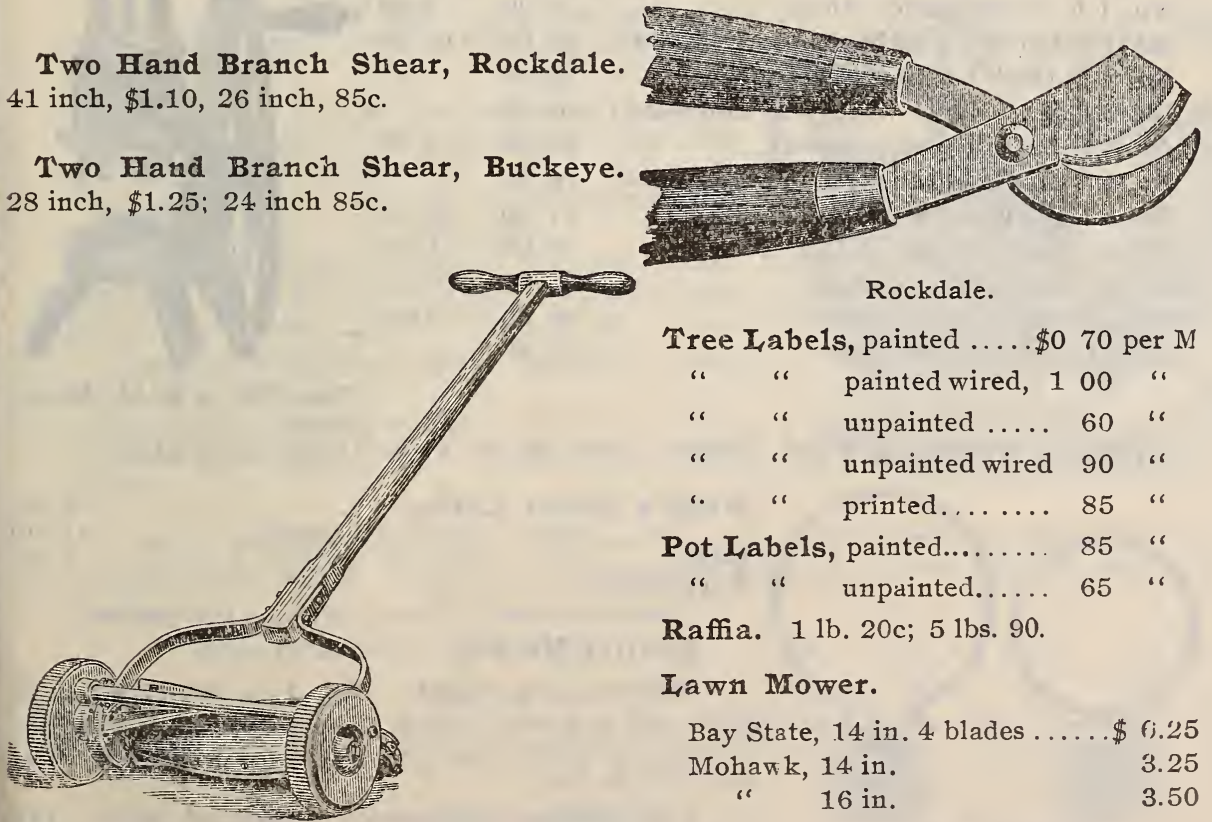

Tree Iabe1s, painted ....\$0 70 per M

“ " " painted wired, 100 “

" " " unpainted .... 60 "

" " unpainted wired 90 "

، " printed...... 85 "

Pot Labe1s, painted....... 85 “

" " unpainted..... 65 "

Raffia. 1 lb. 20c; 5 lbs. 90.

Lawn Mower.

Bay State, 14 in. 4 blades ..... \$ f.'25

Mohaw k, 14 in. $\quad 3.25$

" 16 in. 3.50

Philadelphia Lawn Mower. 12-inch, $\$ 7.00 ; 14$ inch, $\$ 7.50 ; 16$-inch $\$ 8.00$. 


\section{POULTRY SUPPLIES.}

We carry a full line of Poultry Supplies and list in this Catalogue most of the principal articles needed by poultry men. We would request anr one specially interested in this line to write for our Complete Catalogue of Poultry Supplies.

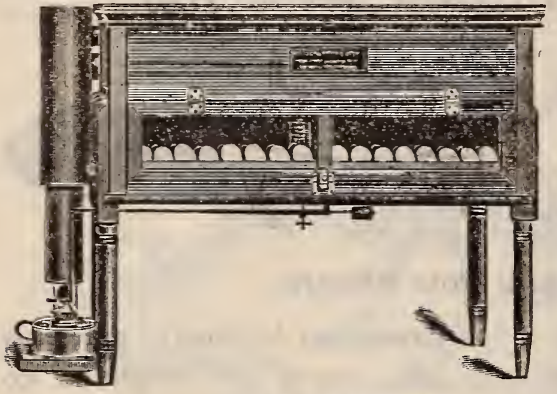

I30-Egg Petaluma.

THE PETALUMA INCUBATOR is a firstclass "hot air" machine. The metal parts are principally of iron and copper, so they will last a lifetime; perfectly self-regulating; known the world over as one of the best egg hatchers made; will hatch anything from silk worm to ostrich eggs. WE PAY FREIGHT TO YOUR TOWN.

Petaluma. 50 Eggs............ \$10.n0

Petaluma. 130 Eggs.......... 20.00

Petaluma. 200 Eggs............ 30.00

Petaluma. 350 Eggs........... 40.00

Little Gem. 120 Eggs......... 20.00

Little Gem. 200 Eggs.........27.50

BROODERS.

Petaluma. Induor, 100 Chick............................... \$ 5.00

Petaluma. Outdoor, 100 Chick ...................................... 12.00

Petaluma. Hot Water Sectional, 200-250 Chick................... 20.00

The Mann Bone Cutters are exceptionally good machines and have given universal satisfaction. They do the work that is expected of them and do it well and rapidly. We believe that you would find one a paying investment, even if your flock of fowls is not very large. Nos. 1 to 8 inclusive, are guaranteed for one year by the manufacturers.

First column, prices at Portland. Second column, FREIGHT PREPAID to any railroad station in Oregon or Washington.

No. $1 \mathrm{C}$, (with crank handle)..........\$6.00\$6.50

No. $1 \mathrm{~B}$, (with balance wheel)......... 8.00

No. 1 B M (balance wheel and iron stand).. 12.00

No. $3 \mathrm{~B}$, (with balance wheel) .......... 14..00

No. 3 B M,.(balance wheel and iron stand). 16.00

No. 4. B, (with balance wheel).......... 14.50

No. 4. B M, (balance wheel and iron stand). 16.50

No. 6 (Post bone cutter)............ 17.00)

No. 2 (Standard bone cutter).......... 20.00

No. 8 (Double hand cutter).............24.00

No. 10 (Small power cutter).......... 28.00

No. 14. (Large power cutter)...

80.00

8.50

12.75

....

15.50

18.00

21.00

25.00

29.00

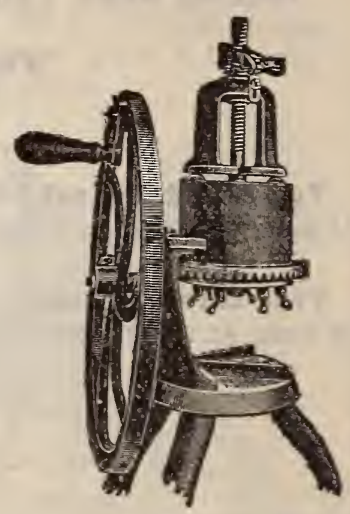

New No. 4 B. M. Mann.

Mann's Swinging Feeä Trays. 18 -in. $\$ 1.00 ; 27$-in. $\$ 1.25 ; 36$-in. $\$ 1.50$.

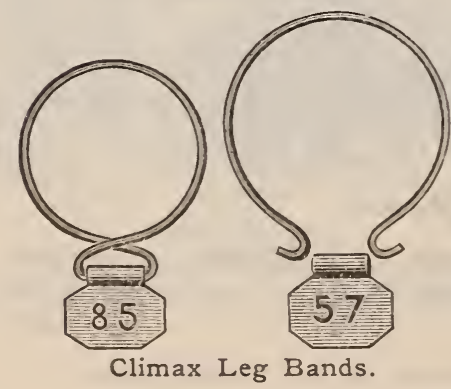

Mann's Clover Cutter, ..............\$9.50 Gem " mounted......... 12.00

Perfection " "

Best low-priced Clover Cutter on the market.

Poultry Marker. By mail 25 cents.

Climax Leg Bands. No. $1,1 / 2$ inch; No. 2, 5/8 inch; No. 3, 3/4 inch; No $4,7 / 8$ inch; No. 5,1 inch; No. $6,1 \frac{1}{8}$ inch. Per doz. $25 \mathrm{c}$; per $25,40 \mathrm{c}$; per $50,75 \mathrm{c}$; per $100, \$ 1.25$.

Leg Bands. The regular copper leg bands. Per doz. $25 \mathrm{c}$. 


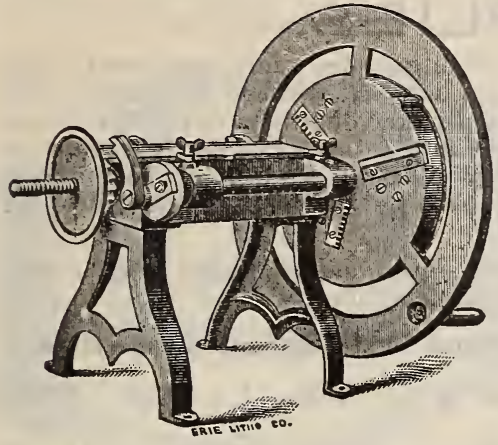

No. I Dandy.

The "Dandy" Bone Cutter is one of the newer machines; is well made, strong, compact and easy running. Grinds all kinds of bones, and can be changed instantly from coarse to fine cut. All styles but the No. 0 are Automatic feed. These machines are guaranteed for one year by the manufacturers. First column Portland prices. Second column prices freight paid to any railroad station in Oregon or Washington.

No. o (with balance wheel) ...\$8.50 \$9.50

No. I (with balance wheel).... $12.00 \quad 13.00$

No. 2 (with balance wheel).... $13.75 \quad 14.75$

No. 3 (with balance whet 1)....20.00 22.00

No. 8 (Power machine) ........36.00 ....

Crown Green Bone Cutter........... 12.00

Crown Green Bone Cutter, mounted:.. 14.00

The Wilson Dry Bone Mill. For grinding shell, burned bone, feed, etc., $\$ 5.00$.

Meat Meal. Fine egg food. $1 \mathrm{lb}$. 2c; 100 lbs. $\$ 1.75$.

Granulated Bone. Your hens need bone. 1 lb. $5 \mathrm{c}$; 100 lbs. $\$ 1.50$.

Oregon Granite Grit. Fowls need grit as much as a horse needs teeth. $1 \mathrm{lb}$. 2c; $100 \mathrm{lbs}$. $\$ 1.10$.

Oyster She11, ground. $1 \mathrm{lb}$. $5 \mathrm{c} ; 100 \mathrm{lbs} . \$ 1.00$.

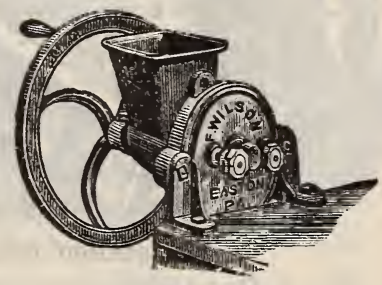

Wilson Mill.

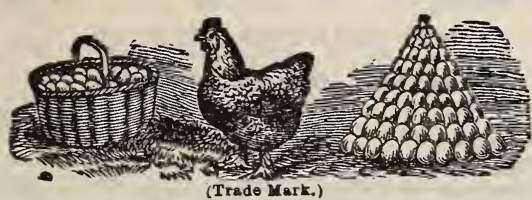

Imperial Egg Food. The best known, and standard egg food. $1 \mathrm{lb} .45 \mathrm{c} ; 2 \mathrm{1} / 2$ lbs. $90 \mathrm{c} ; 6-1 \mathrm{~b}$. box $\$ 1.75 ; 10-1 b$. box $\$ 2.50$.

Egg Maker. A fine Poultry Food. Large pkg. 25c.

Pratt's Poultry Food. A guaranteed egg food of undoubted merit. 26-oz. pkg. 25c; 5-1b. pkg. 60c.

Thanolice. One of the best insect powders for use on poultry. 12-0z. pkg. 25c; by mail, $37 \mathrm{c}$; 26-oz. pkg. 50c; by mail, 76c.

Creosozone. A very effective remedy for lice on fowls. Liquid. Per quart, 50c.

Lambert's Death to Lice. A powder. $5 \mathrm{oz}$. $10 \mathrm{c}$; by mail, $17 \mathrm{c}$; $15 \mathrm{oz}$. 25c; by mail, $43 \mathrm{c}$; $48 \mathrm{oz} .50 \mathrm{c}$; by mail, $\$ 1.02 ; 100 \mathrm{oz}$. $\$ 1.00$.

Lambert's Death to Lice, Ointment. $1 \mathrm{oz}$. 10c; by mail, 12c;

I ambert's Death to Iice, Special. A powder for dissolving in coal oil. 4 oz. 10c; by mail, $16 \mathrm{c}$.

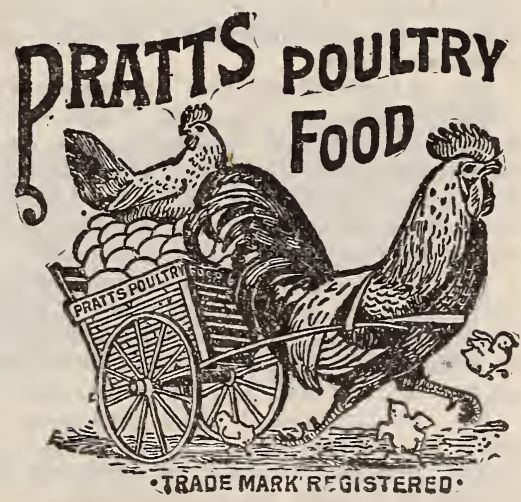

Wire Poultry Netting. This now has come to be almost an indespensable article about a poultry yard. We offer the best quality in pieces 150 feet in length, and widths as follows:

$\begin{array}{rrrrrrrrrr}\text { No. } & 12 & 18 & 24 & 30 & 36 & 42 & 48 & 60 & 72 \\ \text { MESH..Wire } & \text { in. } & \text { in. } & \text { in. } & \text { in. } & \text { in. } & \text { in. } & \text { in. } & \text { i.. } & \text { in. } \\ 2 \text { inch..2(1) } & .70 & \$ 1.00 & \$ 1.35 & \$ 1.70 & \$ 2.05 & \$ 2.35 & \$ 2.70 & \$ 3.40 & \$ 4.00 \\ 2 \text { inch...19 } & .75 & 1.15 & 1.50 & 1.90 & 2.25 & 2.65 & 3.00 & 3.75 & 4.50\end{array}$

Short lengths, 1 cent per square foot. 


\section{BEE SUPPLIES.}

We carry a very large sturk of Bee Supplies, which includes a full assortment of the articles necessary for handling bees in an up-to-date manner. If Bees are to be kept, they should be handled by improved methods, for it is only by keeping them in the best shape that any money can be made with them. We give herewith a list which includes most of the principal articles that are used by bee-keepers. We would request any one who is specially interested in this line to write us for our complete Catalogue of Bee Supplies, the new edition of which will come out in the spring.

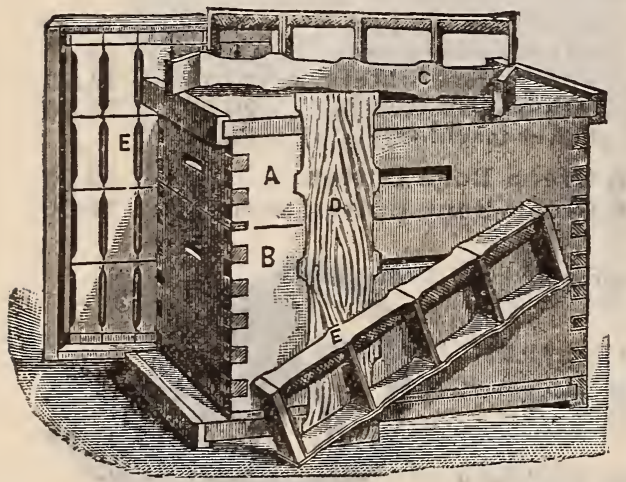

Dovetailed Hive.

No. 1 Dovetailed Hive (complete with 1 super) consists of 1 bottom board, 1 body, 1 super, 1 cover, 8 Hoffman brood frames, 1 division board, 1 follower and 1 wedge ( 1 tightening strip) for super, 6 section holders, 6 slotted separators, 24 section and foundation starters, for frames and sections, and nails.

No. 2 Dovetailed Hive consists of 1 bottom board, 1 body, 1 super, 1 cover, 8 Hoffman brood frames, 1 follower, and one wedge for super and 6 section holders, 6 slotted separators, and nails.

No. 3 Dovetailed Hive (complete with 2 supers) consists of 1 bottom board, 1 body, 2 supers, 1 cover, 8 Hoffman brood frames, 1 division board, 2 followers, and 2 wedges for supers, 12 section holders, 12 slotted separators, 48 sections and foundation starters for frames and sections, and nails.

No. 4 Dovetailed Hive consists of 1 bottom board, 1 body, 2 supers, 1 cover, 8 Hoffman brood frames, 1 division board, 2 followers and 2 wedges for supers, and 12 section holders, 6 slotted separators, and nails.

No. 10 Dovetailed Hive (complete twostory for extracting) consists of 1 bottom board, 2 bodies, 1 cover, 16 Hoffman brood frames, 2 division boards and nails.

\section{Table of Prices of Falcon Dovetailed Hives. Nailed or K. D, Packed. In Flat. Weight. \\ Order by No. $1 \quad 10$ of 10 \\ 1. Complete. $\$ 1.80 \quad \$ 15.00 \quad 300$ \\ 2. Envty .... $1.50 \quad 12.50 \quad 280$ \\ 3. Complete.. 2.40 $19.50 \quad 380$ \\ 4. Empty ... 1.95 $16.00 \quad 340$ \\ 5. Complete.. $1.90 \quad 16.50 \quad 300$ \\ 6. Empty....1.70 14.00 280 \\ 10. Empty...2 2.00 $16.50 \quad 320$ \\ Five Hives at same rate as ten.}

Extra supers, empty, nailed $40 \mathrm{c}$; in flat, $35 \mathrm{c}$; complete, $50 \mathrm{c}$.

\section{Portland Seed Company's Pine Hive.}

Order by No. Nailed, or K. D. Packed. In Flat.

1. Complete ......\$1.6n $\$ 10$

2. Empty........... $1.35 \quad 11.00$

3. Complete ....... 2.10 17.50

4. Empty........ 1.70 $\quad 14.00$

10. Empty ......... 1.65 13.00

Five Hives at same rate as ten.

\section{Portland Seed Company's Cedar Hives.}

Order by No. Nailed, or K. D. Packed, In Flat.

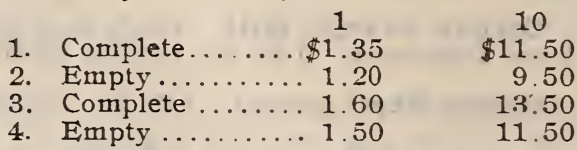

Five Hives at same rate as ten.

Price List of Brood Frames.

\begin{tabular}{|c|c|c|c|c|}
\hline Name. & 10 & $\begin{array}{l}\text { nl Flat- } \\
100\end{array}$ & 1000 & $\begin{array}{l}\text { Weight } \\
100 .\end{array}$ \\
\hline $\begin{array}{l}\text { Hoffman frames with } \\
\text { projections on side }\end{array}$ & & & & \\
\hline $\begin{array}{c}\text { bars only } \\
\text { Tri-top-bar Frame }\end{array}$ & .25 & $\$ 2.15$ & $\$ 18.50$ & 351 \\
\hline Improved Foundation & & & & \\
\hline $\begin{array}{l}\text { Fastening Frames. } \\
\text { Thick-Top Bar Staple }\end{array}$ & .25 & 2.25 & 2000 & \\
\hline ..... & .25 & 2.15 & 185 & \\
\hline
\end{tabular}

\section{Price List of Separators.}

$\begin{array}{lrrr} & 100 & 1000 & \text { Wt. } 100 \\ \begin{array}{c}\text { Slotted wood sep- } \\ \text { arators, 41/2X18 }\end{array} & & & \\ \text { f o r Dovetailed } & & & \\ \text { supers........ } & .75 & \$ 7.00 & 7 \text { lbs. } \\ \begin{array}{c}\text { Sloited wood sliced } \\ \text { separators..... }\end{array} & .50 & 4.00 & \\ \text { Plain separators.. } & .45 & 3.75 & \end{array}$

\section{Section Holders.}

Section Holders for Dovetailed Hives are made with bottoms $1 / 4$ inch thick by $17 / 8$ inch wide, and are cut out to fit insets of sections. The ends are $1 / 2 \times 17 / 8 \times 41 / 4$. They have no top-bar, nor are separators included in price: $10,20 \mathrm{c}: 100, \$ 1.40$.

Section-holder bottonis or patteris slats, $100,75 \mathrm{c}$.

\section{Porter Bee Escape.}

This is one of the hest escapes known, and is far superior to almost all others. Price 20c, by mail; $1 \mathrm{doz} . \$ 2.25$. Mounted, each, 40c. 


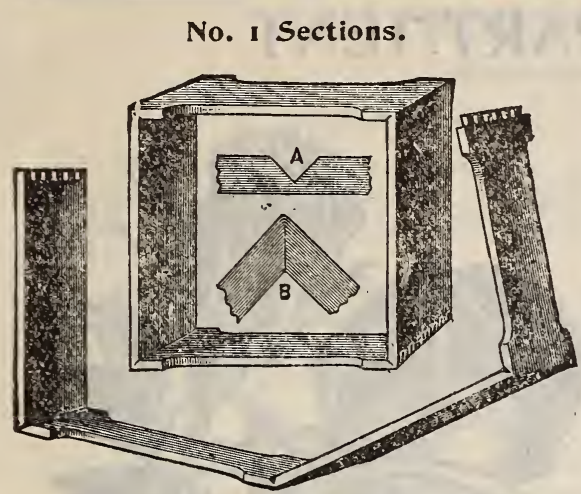

Table of Prices.

Per 100

500

.50

$\$ 1.80$

No. $1,41 / 4 \times 41 / 4 \times 17 / 8$.

No. $1,4 \frac{1}{4} \times 4 \frac{1}{4} \times 115-16$.

No. $1,41 / 4 \times 41 / 4 \times 13 / 4$.

No. $1,4.1 / 4 \times 4 \frac{1}{4} \times 7$ to the foot.

\section{Cheap Sections.}

We offer a fair quality of section as follows: $100,35 \mathrm{c}, 500, \$ 1.50 ; 1000, \$ 2.75 ; 3000$, $\$ 7.75$.

For larger quantities, write for special prices. If ordered by mail, allow 1c. each for postage. Sample section by mail free. We have in stock $51 / 4 \times 51 / 4 \times 17 / 8$ and 1 15-16 Falcon sections. Price $\$ 1.00$ extra per 1000. We also carry plain for cleated or fence separators. $41 / 4 \times 4,1 / 4 \times 11 / 2$. Price same as No. 1 .

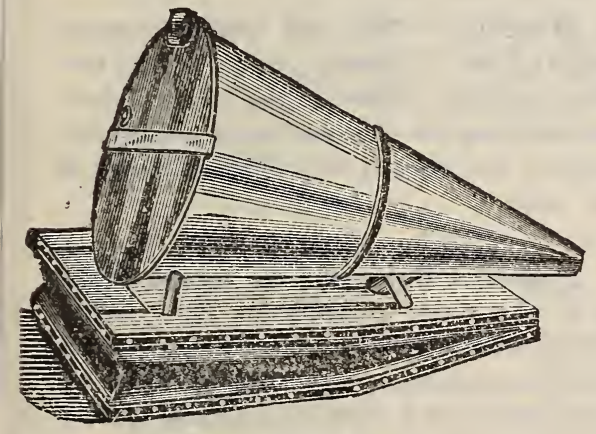

Clark's Cold Blast Smoker.

Price $60 c$; by mail, $75 c$,

\section{Bingham Smoker}

Each. By mail Conqueror ........\$0 90.....\$1 15 Little Wonder....... $55 \ldots \ldots \ldots \quad 75$ Doctor.......... $125 \ldots \ldots \ldots 150$

\section{Crane Smoker.}

Price $\$ 1.50$; by mail, $\$ 1.80$.

\section{Corneil Smoker.}

Price $\$ 1.00$; by mail, $\$ 1.20$.

\section{Comb Foundation.}

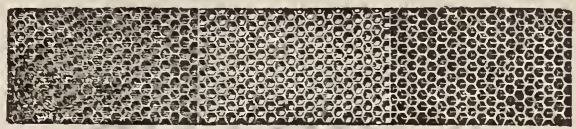

Our foundation is made from Pure Beeswax.

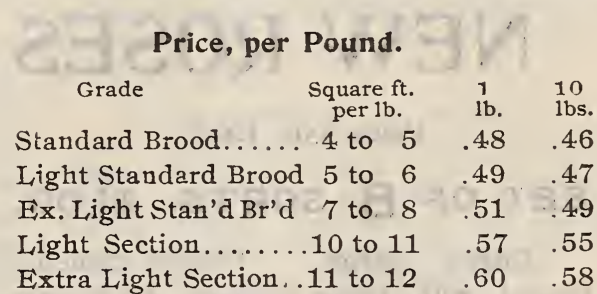

Prices subject to market changes.

If foundation is wanted by mail, add $25 \mathrm{c}$. per 1b. up to $2 \mathrm{lbs}$, and 20c per 1b. over 2 lbs.

We pay the Highest Price for Bees Wax.

\section{Honey Extractors.}

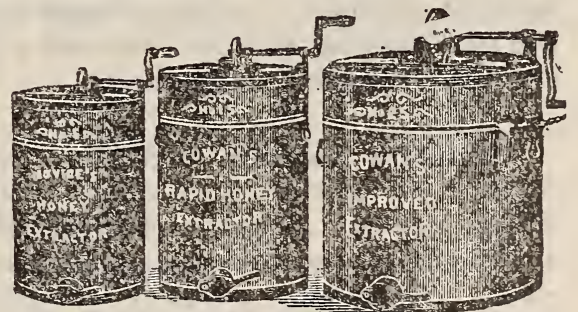

Novice, No. 5, price...........\$ \$9.25

Cowan No. 15, price............12.00

Price List of Veils.

No. 1 Veil, made entirely of silk tulle, $80 \mathrm{c}$.

Nor 1 Veil, cotton tulle, with silk tulle face, $50 \mathrm{c}$.

No. 3 Veil, cotton tulle throughout, 40 c.

No. $31 / 2$ Veil, mosquito bar with silk tulle face, $40 \mathrm{c}$ 


\section{PLANT DEPARTIENT.}

We wish to call the attention of our customers to our select list of Roses and other plants. Our stock is all grown in $2 \frac{1}{2}$ and 3 -inch pots, is strong and healthy and cannot fail to give satisfaction. We send all plants by mail postpaid, unless ordered otherwise. 5c. extra for postage must accompany orders for less than 50c. worth.

\section{GRAND NEW ROSES}

Price, 15c. Each.

\section{SET OF 8 SORTS, $\$ 1.00$.}

Baron Berge. Flowers Camellia formed, with pteals recurved; color light yellow with a pink border to the petals; center, bright China rose. One of the best new roses.

Golden Gate. Cream white; center and base of petals soft, golden yellow, exquisitely bordered with clear rose; buds long and pointed. One of the finest and most beautiful new roses. Its extraordinary size and free-blooming qualities commend it to everyone who wishes the finest roses.

Kaiserin Augusta Victoria. This is one of the grandest of all roses. It is a strong, vigorous grower, producing buds and flowers of enormous size. Color, pure white. We have no hesitancy in saying that this rose is unequaled by any other variety of its color. It is a grand winter bloomer, and is largely forced for cut flowers. A grand garden rose on account of its vigorous growth and hardiness.

Maman Cochet. This is one of the most beautiful new Tea roses that has been introduced in years. The growth is vigor ous with rich, healthy foliage and extra large flowers on long, stout stems, very double and simply exquisite when in bud or half blown. The color is a deep, rosy pink,

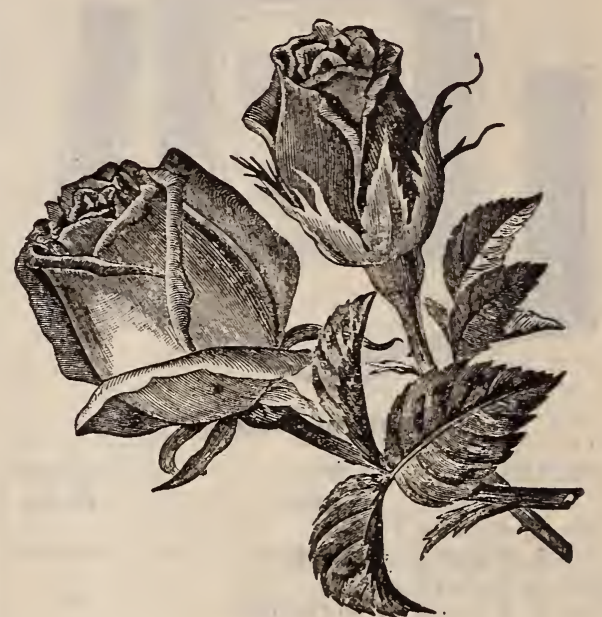

the inner side of petals silvery rose. Makes charming bunches of long-stemmed flowers when cut.

Media. Flowers bright lemon, with canary center; of immense size and very double. One of the most promising yellow roses, and altogether a splendid 6ort, worthy of extensive cultivation.

Mose11a. The new yellow-flowered Soupert Rose. Flowers creamy white, shaded to apricot yellow in the center; about the same size as the well-known Clothilde Soupert, and equally as profuse in bloom as that sort.

Princess Bonnie. We regard this as one of the finest roses in our list. Every shoot produces flowers of good size, which in bud state surpess any rose we know of. Outer petals are a rich, solid crimson, more vivid than "Jack," while the inner side of the center ones at the hase is streaked with white.

Madame Caroline Testout. A grand new rose of the La France type, but with flowers larger and finer. Color, bright, satiny pink, very fragrant and free in bloom. One of the handsomest roses in our collection and should be planted extensively. 


\section{EVERBLOOMING ROSES.}

\section{Rainbow Collection.}

\section{ro Cents Each; 7 for 50 Cents: $I_{5}$ for $\$ 1.00$.}

Bougere. This is a superb rose; extra large, very double and full; exceedingly sweet tea scent; color, bronze rose, delicately shaded with lilac.

The Bride. The finest white rose ever offered. The buds are very large and of exquisite form, and the full flower is very double, measuring from $31 / 2$ to 4 inches in diameter.

Duchesse de Brabant. Color a soft rosy flesh, changing to deep rose, shaded amber and salmon; delightful tea scent: beautiful buds and flowers. A rose having every desirable quality.

Catherine Mermet. A very beautiful Tea Rose, valued highly for its beautiful buds. Faultless in form and charming in every shade of color, from the purest silvery rose to the exquisite blend of yellow and rose which illumines the base of the petals.

H. M. Stanley. Very large flowers of great substance; color, beautiful amber rose, delicately tinged apricot yellow. One of the rarest colored roses in our collection.

J. B. Varrone. Intense, scarlety crimson; beautifully shaded with buff rose at the center: another rich and rare color in the rose family.

Triumphe de Pernet Pere. Flowers extra large, thick petals and long-pointed buds, with a delicious tea scent. Color, a fine, clear, magenta red, passing to bright crimson. Very brilliant and attractive.

White Ia France. In this new variety we have one that we can recommend to all. Beautiful, pearly white, sometimes tinted with fawn. A grand variety for any purpose, and should be planted by every lover of fine roses.
Madame Philemon Cochet. Color, delicate pink shaded salmon; flowers cupshaped, borne in great profusion.

Madame Francisca Kruger. The striking color of this handsome rose places it at the front as a bud producer in the open ground. It is closely allied to Catherine Mermet in everything save color, which is deeply-shaded, coppery $y \in l l o w$. One of the finest roses in existence.

Marie Van Houtte. Of a fine, fauitless straw yellow color; outer petals washed and outlined with bright, rosy carmine; occasionally the whole flower will be suffused with light pink.

Papa Gontier. A magnificent red rose: flowers large and semi-double; a vivid cherry-red color, shaded yellow; reverse of petals crimson; free growing and flowering very profusely. One of the very best and most valuable for open ground. No other red Tea rose can compare with it.

Rainbow. An elegant new striped rose, bearing freely beautiful buds and flowers of large size; color, a beautiful shade of deep pink, distinctly striped and mottled with brilliant crimson, elegantly shaded and toned with rich amber; very fragrant and exquisitely beautiful.

Safrano. Bright apricot yellow, tinged orange and fawn. Valued highly for its beautiful buds. A rampant grower, very profuse in bloom and deliciously tea-scented.

Sombriel. Finely formed flowers of a beautiful white, tinged with delicate rose. Flowers large and full, blooming in clusters

\section{HARDY ROSES. Iron-Clad Collection.}

\section{Price ro cents each. Set of Six Sorts 50 cents.}

Baron de Bonstettin. Splendid, large flowers, ver $\bar{p}$ double and full; color rich, dark red, passing to deep velvety maroon.

Coquette des Alpes. A lovely, pure white rose; large, full, finely-formed flowers, borne in great profusion. A very desirable variety.

General Jacqueminot. Bright, shining crimson, very rich and velvety; ex. ceedingly brilliant and handsome; makes magnificent buds, and is highly esteemed as one of the best and most desirable for open ground.
Giant of Battles. This is still esteemed as the very best rich red Rose. Very large, double, full and sweet. Excellent.

La Reine. A beautiful, clear, bright rose; fine, full form, very fragrant. It is well named "The Queen"

Marchioness of Lorne. This beautiful rose produces flowers of an exceedingly rich, fulgent rose color, slightly shaded in the center with a vivid carmine. They are large and very sweet, full and finely cupped shape. Petals large and buds long and handsome. 


\section{CLIMBING ROSES. \\ Crimson Rambler Gollection.}

Price ro cents each; set of Seven Sorts, 50 cents.

Crimson Rambler. A charming pillar rose. The flowers grow in great pyramidal panicles; each carries thirty to forty blooms. The flowers are 1 to $1 / 2$ inches in diameter, and remain in perfect condition on the plants for a long time. The color is a bright, vivid crimson, showing none of the purplish tint so commonly seen in crimson roses.

Ia Marque. Flowers of a good size, borne in large clusters, which are the distinctive features of the rose. Established plants bear thousands of blossoms. Color pure white; one of the best-known varieties.

Madame Alfred Carriere. Extra large, full flowers, very double and sweet, and a most profuse bloomer; color, rich, creamy white, faintly tinged pale yellow.
Marechal Neil. A magnificent deep, golden yellow variety, so famous as to need no description. Grown the world over for its immense yellow flowers. The ñnest rose of its color in existence.

Elie Beauvilain. Flowers are very large and full; fine silvery rose, tinted coppery yellow. A rapid climber of great merit.

Golden Chain, or Climbing Safrano (Reve d'Or.) A beautiful pillar rose, being a strong climber. Color, orange-yellow or deep saffron; good size, full and sweet.

Reine Marie Henriette. A strong, vigorous grower; flowers large, full and of fine form; color glowing crimson, elegantly shaded; very beautiful; one of the best climbers.

\section{CARNATIONS--STANDARD VARIETIES.}

\section{American Flag Collection.}

\section{ro cents each. Set of Fourteen for \$r.0o.}

American Flag. A most distinct and novel variety. Regularly striped, vivid scarlet and purest white. Vigorous grower and profuse bloomer.

Anna Webb. Color, brilliant dark crimson, shaded with richest maroon; beautifully fringed petals; a splendid bloomer.

Daybreak. The Favorite Carnation, because of its rare and lovely color; a very pure, bright shade of flesh pink in a large, full-fringed flower of rich fragrance and perfect form. The plant is bushy and strong, blooming early.

Goldfinch. The flowers are of large size, full, perfectly formed and very fragrant; lemon yellow with clear line of carmine defining the fringe of the petals; stronger and freer blooming than any other yellow carnation.

J. J. Harrison. Color, a pearly white delicately edged and striped pink. One of the finest and most beautiful varieties in our collection.

Lizzie McGowan. A grand new sort; flowers very large, pure white, beautifully fringed and very fragrant. Pure in color, perfect in form, healthy and productive.

Mrs. Cleveland. A beautiful shade of salmon piuk; large and has a waxy ap- pearance not seen in other varieties.

Portia. Intense bright scarlet; vigorous constitution. One of the best sorts in cultivation.

President Garfield. A fine scarlet variety; well known and popular.

Silver Spray. A grand, pure-white, early-flowering carnation. Makes a fine, bushy plant, and bears an abundance of large flowers; nicely fringed; very fragrant.

Tidal Wave. A very attractive shade of carmine not heretofore seen in the carnation family. Flowers extremely double and of the most perfect form.

William Scott. This is a most promising noveltv and undoubtedly the freest blooming of all pink carnations.

Puritan. Fine white; large size; very fragrant, and an early and profuse bloomer; flowers of remarkable substance and of fine form.

Nellie Iewis. Very large and handsome flowers; color, a beautiful flesh, flaked and splashed with dark pink; very distinct and sure to becone popular.

Golden Gate. Undoubtedly the finest pure yellow yet introduced; color, pure goldeu rellow, without stripe or variegation of any kind; beautifully fringed. 


\title{
CARNATIONS-COntn'd.
}

\section{Eight Fine New Varieties.}

\section{I5 cents each. Set of Eight Sorts, \$r.0o.}

Della Fox. Delicate shell pink; vigorous, wiry grower; medium to large flowers on strong, stiff stems; color, soft and exceptionally pleasing; flower a splendid keeper; one of the most attractive colors in pink carvations.

Dr. Smart. Ground color, cream white; sufused and margined with bright crimson; deliciously fragrant and very tree flowering.

E1dorado. A yellow, of free-blooming habit: strong, vigorous plant: erect stems; finely-formed flower, of fair size; very free. Petals edged with a narrow band of light pink, almost a Picotee in marking. The flower remains in its yellow color under artificial light, unlike most yellow varieties.

Jubilee. Color, richest shade of intense scarlet ever seen in a carnation; flowers massive and of great substance; very fragrant and free flowering; one of the grandest new sorts.

Meteor. Magnificent large flowers of a beautiful, deep, brilliant, scarlet-maroon color. Pronounced the richest shade of color yet seen in carnations.

Storm King. A magnificent white carnation; very large, full, symmetrical, snow-white flowers, borne on stems 18 inches in length; deeply fringed and sweetly scented.

Princess Bonnie. Light pink ground, prettily marked and penciled with a darker shade. One of cur finest fancy sorts.

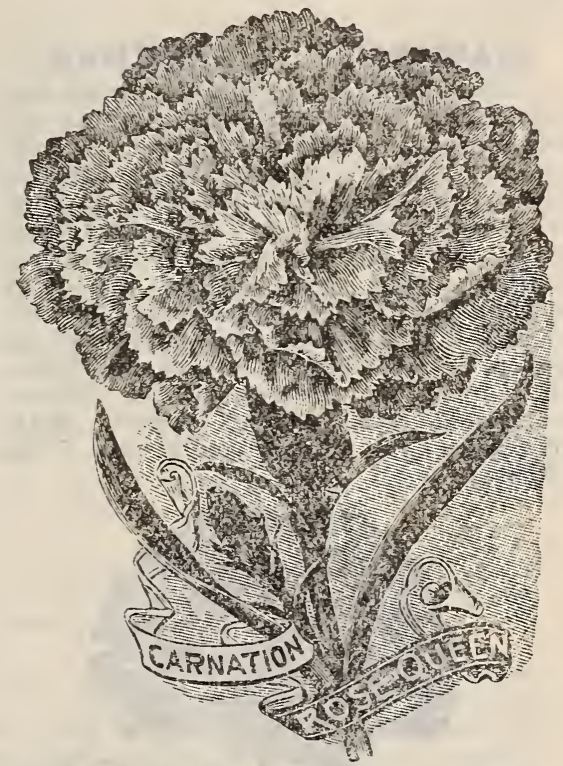

Rose Queen. This variety has been greatly admired, wherever it has been seen, for its desirable color, being a beautiful delicate shade of pink; flowers of large size and very freely produced; plant of grand habit and vigorous growth.

\section{LARGE FLOWERING JAPANESE CHRYSANTHEMUMS.}

\author{
Price ro cents each. I5 for $\$ 1.00$.
}

Co1. W. B. Smith. Beautiful incurved flowers, forming a mass of rich golden bronze color, very large and fine; early.

Charles Davis. Rich, tawny yellow and golden bronze; very large reflexed petals. One of the finest for exhibition.

George W. Childs. No Crysanthemum has created such a sensation as this. Of immense size, and of the richest, deep, velvety crimson. Winner of four gold medals.

Ivory. Snowy white, of perfect incurved form; very large. This is, undoubtedly, one of the most useful varieties ever introduced.

J. E. Lager. Very early yellow reflexed Japanese, of good size, color and substance.

John Shrimpton. Velvety crimson. A grand Japanese reflexed variety of magnificent form; much superior to Culling fordii.

Marion Henderson. A handsome yellow variety of pure tint; splendid in size and form and a magnificent addition to the very early varieties.

Major Bonraffon. Soft, clear primrose yellow, six inches in diameter and nearly as deep, forming a perfect globe.

Mrs. Henry Robinson. Immense, globe-shaped pure-white flowers; one of the grandest sorts for exhibition.

Niveus. A grand snow-white variety. center incurving, with outer petals reflexed nearly to the stem; indispensable to any collection.

Pink Ivory. Differs from Ivory only in color, which is a beautiful silvery pink; one of the best.

President W. R. Smith. Flowers heavy in substance and of beautiful texture; color, flesh pink; fine for cut flowers.

Philadelphia. A very large, round, incurred Japanese flower, with grooved pointed petals of great width; the reverse is 


\section{CHRYSANTHEMUMS-Contn'd.}

ribbed and the color white, with a faint primrose marking at the tips.

Merry Monarch. A very large, early white variety; one of the finest for open-air culture.

\section{MAMAOTH VERBENAS.}

The verbena is one of the prettiest and most popular of all the flowering plants suitable for forming beds on the lawn. It commences to flower and spread from the first day the plants are set until late in the autumn, every day becoming better and more handsome. Our plants are grown with care and are very robust. New varieties are being constantly introduced and old ones discarded, so that it is difficult, and we might say useless, to offer a long list of named varieties. The colors range through all the different shades of scarlet, purple, crimson, pink, blue, white, etc. Price 8 cents each; 7 for 50 cents.

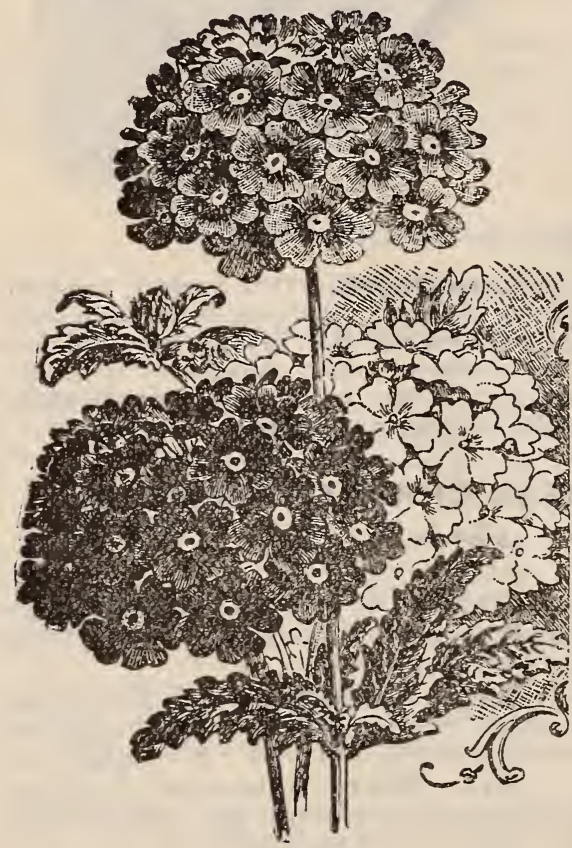

FUCHSIAS.

Io cents each, 6 for 50 cents.

Phenomenal. The largest Fuchsia that grows. Tube and sepals bright coral red; corolla rich violet purple. A very popular sort.

White Giant. A superb new double white variety. Tube aud sepals bright scarlat; corolla large, double and waxy white. An excellent grower and profuse bloomer. 15 cents each.

Esmeralda. Tube and sepals bright
Viviand Morel. An enormous flower lasting a long time; petals straight and loosely arranged; a beautiful light shade of pink.

red: corolla very large and double, of a beautiful lilac color, changing to clear rose.

Annie Earle. A beautiful new sort; corolla clear carmine; sepals waxy white.

Ear1 of Beaconsfield. Tube and sepals light, rosy carmine; corolla deep carmine. Flowers three inches long and very distinct.

Monsieur Thibaut. A strong grower and free bloomer. Sepals dark red; corolla rose vermillion tinted violet. An extra fine variety.

\section{HARDY GARDEN PLANTS.}

Japanese Anemones. One of the finest herbaceous plants, particularly valuable because of their season of blooming. They commence to open their handsome single flowers three inches across, in August and continue to grow in beauty until cut by frost. Pink or White, 10 cents.

Coreopsis. Lanceolata. One of the most beautiful hardy plants in existence, bearing profusely all summer large golden yellow flowers on long stems, making it specially adapted for cutting. 10c. each.

Paeonies. RED, WhITE, PINK; each, 25c; by mail, 40 c.

Gaillardia. Grandiflora. Large, gorgeous flowers having a red-brown center and petals marked with rings of crimson, orange, vermillion, etc. ; 15 cents each.

Plumbago. Lady Larpent. A fine perennial, growing into compact chunks about a foot high, and covered from July until frost with rich violet-blue flowers; extra fine; 10 cents each.

B1ue Spirea. This very valuable autumn-blooming, shrubby plant is a native of China. It is easy to grow, is hardy and blooms abundantly. Its color is beautiful, an exquisite shade of auzure blue, and flowers luxuriantly in a pot or in the open ground; its blooming period is in the fall, from September until heavy frosts, when flowers are scarce and hardly anything is to be had in its color. 15 cents.

Perennial Phlox. No garden should be without these showy and satisfactory plants. They are as hardy as an oak grow rapidly, making large clumps in a short time, and bear in the summer and fall massive panicles of flowers in unusual shades of rose, salmon, mauve, dark red and white. 15 cents each; set of 6,60 cents. 
Rudbeckia. Golden Glow. A new hardy plant, growing very tall, branching freely and bearing hundreds of beautiful golden-yellow flowers as large as a dahlia. The most effective hardy plant for August and September flowering now in cultivation. 15 cents each.

Double Violets. Of all the delightful perfumes that of the sweet violet is the most delicate and pleasing, and places this modest flower among our greatest favorites. They bloom profusely in the spring, or earlier, if planted in a cold frame. 10 cents each.

\section{MISCELLANEOUS PLANTS.}

Begonias. Most useful, ornamental and handsome house plants. No class of plants will grow and bloom better under ordinary care than the Begonia. Most of the varieties are very free growing, and in a short time make handsome specimen plants 20 sorts 10 cents each; 6 for 50 cents.

French Cannas. Where brightest and most $1 \mathrm{mposing}$ effects are desired in bedding the Canna is unequaled. Recent years have wrought wonderful improvement in the Dwarf French race, increasing its beauty a hundred fold. Price 15 cents each; 4 for 50 cents.

Calla Ethiopia (Lily of the Nile.) An old and well known house plant; white trumpet-shaped flowers; 10 and 25 each.

Cyperus Alternifolius (Umbrella plant). A beautiululeasy-growing plant that is admirably adapted to many different modes of culture; in lact, it seems to thrive in almost any situation. Rush like stems with long, narrow leaves radiating from the summit at right angles, drooping in an umbrella form; 10 cents each.

Heliotropes. These plants are universal favorites on account of their delightful fragrance, flowering equally well as bedding plants in the summer or as pot plants in the house during the winter. Price 10 cents each.

Marguerites. (Paris Daisies). Excellent bedding plants, blooming profusely all summer. Two sorts, yellow and white, 10 cents each.

Mexican Primrose. A remarkable free blooming plant of low, spreading growth, seldom growing over ten inches high, but inclining to a trailing habit. Flowers about two inches in diameter, of a clear pink color, veined with scarlet, and with a white center; 10 cents.

Pelargoniums. These are commonly known as the Lady Washington Geraniums. When in bloom, d uring the summer months, they are very beautiful and ornamental, either as pot plants or in the garden. Price 20 cents each; 3 for 50 cents.

\section{HARDY FLOWERING SHRUBS.}

Our Shrubs are large two-year-old, fieldgrown plants, and can only be sent by express or freight.

Azalea. Molis. The most gorgeous of all hardy shrubs. The blossoms, which vary in color from intense crimson to lemon yellow, are borne in greatest profusion in early spring before the leaves appear. It makes a compact, symmetrical shrub, and is destined to become universally popular. 60 jents each.

Berberry. Thunbergir. A new Japanese shrub, bearing pretty yellow flowers, followed by crimson berries remaining on the branches all winter. 30 cents each.

Deutzia. Crenata Fr. Pl. Flowers double white, tinged rose on outside of petals, borne in great profusion during June. 30 cents each.

GRACILIS. A very desirable dwarf-growing variety; beautiful, pure white, bellshaped flowers. 30 cents each.

Hydrangea. Paniculata Grandiflora The flowers are pure white, afterwards changing to pink, and remain beautiful until destroyed by frost. They are borne in immense pyramidal clusters nearly a foot long and about as much in diameter. To secure the finest flowers, prune severely early in the spring. One-year-old plants, 15 cents; two-year-old plants, 30 cents.

Iilac. VULGARIS. Immense heads of beautiful purple flowers; very sweet. 30 cents each.

Vulgaris AlBA. Beautiful, pure white flowers. 30 cents each.

Spirea. Bumalda. A handsome new Japanese variety of dwarf compact habit; covered during the summer and fall with a mass of bright rose-colored flowers; fine and distinct. 30 cents each.

VAN HouTTE. Covered in June with a mass of large white flowers, making a beautiful appearance. 30 cents each.

Viburnum. OPULus. The well-known Snowbal with globular clusters of white flowers. 30 cents each.

Wiegelia. CANDIDA. Beautiful, white flowers; a continuous bloomer. 30 cents each.

RoseA. A fine shrub bearing rose-colored flowers in May and June. 30 cents each. 


\section{NURSERY DEPARTTMENT.}

Our complete Nursery Catalogue, which contains a list of fruit, shade and ornamental trees, shrubs, climbers and roses, is issued in the fall, and we should be pleased to mail it to any one who is thinking of purchasing a stock of trees. We simply give below a condensed list of the fruit-bearing varieties, a short description of each of which will be found in our nursery catalogue above referred to. If you wish it, write us a postal card, and we will mail it immediately without charge.

\section{Apples.}

1 yr., 4 ft., per 10 , \$90; per $100, \$ 7.00$. 2 yr., 5 ft., per 10, 1.00; per 100, 9.00 .

\section{SUMMER.}

Early Harvest, Golden Sweet, Red Astrachan, Red June, Sweet June.

\section{AUTUMN.}

Fameuse or Snow, Gravenstein, Rambo, Twenty Ounce.

\section{WINTER.}

Baldwin, Ben Davis, Blue Pearmain, Esopus Spitzenburg, English Golden Russet, Jonathan, King of Thompkins County, Lady, Lawver, Red Cheek Pippin, Northern Spy, Rome Beauty, Roxbury Russet, Rhode Island Greening, Waxen, Yellow Newtown Pippin, Yellow Bellflower.

\section{Crab Apples.}

1 yr., per 10, \$90; per 100, \$8.00.

2 yr., per 10, 1.25; per 100, 10.00 .

Hyslop, Red Siberian.

\section{Apricots.}

1 yr., 3 to 4 ft., per 10 , \$1.00; per $100 \$ 9.00$. $1 \mathrm{yr} ., 4$ to $6 \mathrm{ft}$., per 10 , 1.50; per 10012.00 .

Royal, Muorpark.

\section{Cherries.}

1 yr., 3 to $5 \mathrm{ft}$, per $10, \$ 1.00$, per $100, \$ 9.00$. 2 yr., 5 to $7 \mathrm{ft}$., per 10, 1.25, per 100, 11,00 .

May Duke, Elton, Gov. Wood, Black Tartarian, Black Republican, Royal Ann, Kentish, Late Duke, Oregon, Bing; Hoskins, 25c; Lambert, $25 \mathrm{c}$.

\section{Peaches.}

1 yr., 3 to $4 \mathrm{ft}$, per $10, \$ 1.25$; per $100, \$ 10.00$. $1 \mathrm{yr}$., 4 to $6 \mathrm{ft}$., per 10, 1.50 ; per $100,11.00$.

Crawford's Early, Hale's Early, Crawford's Late, Early Charlotte.

\section{Quinces.}

2 yrs., 4 to $6 \mathrm{ft}$, $1,25 \mathrm{c}$; per $10, \$ 2.00$. Ex. large, $35 \mathrm{c}$; per $10,2.50$.

Orange or Apple.

\section{Pears.}

$1 \mathrm{yr} ., 3$ to $4 \mathrm{ft}$., $\quad$ per $10, \$ 85 ;$ per $100, \$ 7.00$ 2 yr. 4 to $6 \mathrm{ft}$, " 1.25 ; " 10.00 2 \& 8 yrs., 5 to $7 \mathrm{ft}$., " $\quad 2.00 ; \quad$ " 15.00 .

\section{SUMMER.}

Bartlet, Clapp's Favorite, Early Butter, Madelein.

\section{AUTUMN.}

Beurre d'Anjou, Beurre Clairgeau, Fall Butter, Seckle.

\section{WINTER.}

Easter Beurre, Pound, Winter Nellis.

\section{Plums.}

1 yr., 4 to $6 \mathrm{ft}$., per $10, \$ 1.00$, per $100, \$ 9.00$ 2 yrs., 5 to $7 \mathrm{ft}$., ex. large, 1.50, " 10.00 .

Bradshaw, Coe's Golden Drop, Damson, Peach Plum, Reine Claude, Yellow Egg, Columbia.

\section{Prunes.}

$1 \mathrm{yr} ., 4$ to $6 \mathrm{ft}$, per $10, \$ .75$, per 100 . $\$ 6.00$ 2 yr., 5 to $7 \mathrm{ft}$., per 10, 1.00, per 100 , 8.00

French or Petite, Golden, Hungarian, Italian, Silver.

\section{Grapes.}

1 and 2 yr., per $10, \$ 1.00$, per $100, \$ 8.00$.

Eaton, Moore's Early, Niagara, Concord, Delaware, Moore's Diamond, Worden.

\section{Currants.}

Per doz. 50cts. Per $100 \$ 4.00$.

Fay's Prolific, Red Cherry, White Grape, Black Naples.

\section{Raspberries.}

Per doz. 50 cts. Per $100 \$ 3.00$.

Cuthbert, Greyg, Red Antwerp.

\section{Blackberries.}

Per doz. 50 cts. Per $100 \$ 3.00$.

Lawton, Kittatinny, Erergreen.

\section{Gooseberries.}

Oregon Champion, Per doz. 50 cts. Per $100, \$ 3.00$. Industry, Corliss, per doz. \$1.00. Per 100, 5.00 .

\section{Strawberries}

Per doz. 30c, postpaid; per 100 50c, per $1,000 \$ 3.50$.

Sharpless, Wilson, Triumph, Clark Seedlings. Nagoon. Per doz. 35c, postpaid; per $10075 \mathrm{c}$; per MI write for quotations. 

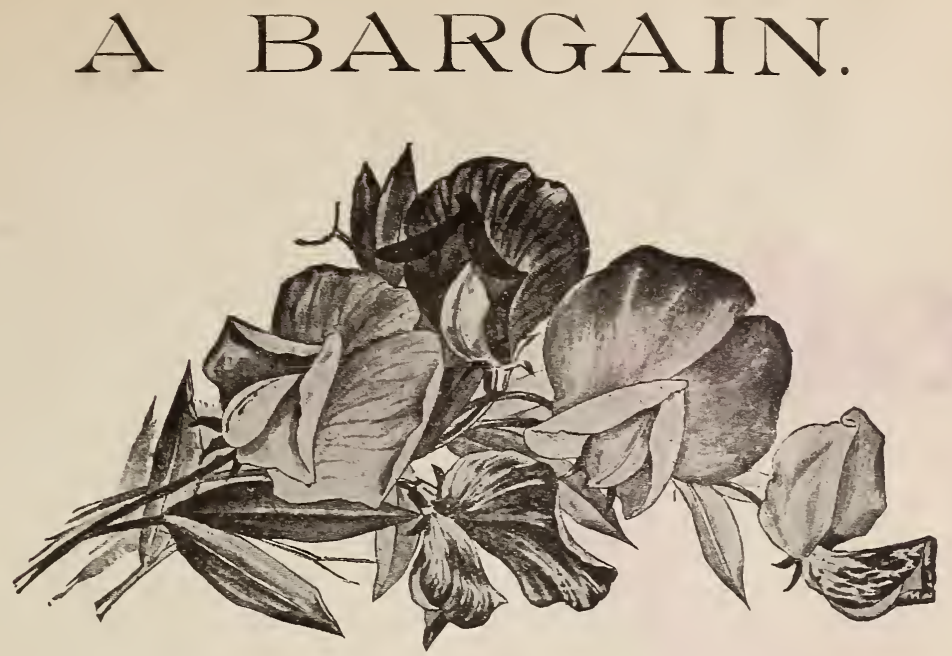

To enable our customers to supply themselves with the choicest varieties of Vegetable and Flower Seeds and Bulbs for a small outlay, we offer the following collections, consisting of fine assortments of favorite vegetables and flowers. With No. 3 one can fill a whole flower garden with bloom from early spring to late fall.

All the following collections sent postpaid to any address at prices stated.

NO. I. SWEET PEAS.

Worth 70c; for 50c.

Blanche Burpee, Mrs. Eckford, Prima Donna, Mars, Capt. of the Blues, New Countess, Stanley, Ovid, Blanche Ferry, Butterfy, Capt. Clark, Gaiety, Lottie Eckford, Ramona.

\section{No. 2. PANSIES AND SWEET PEAS.}

Worth $80 c$; for 60 c.

Five packets Pansies as follows: Trimardeau Mixed, Faust, Victoria, Snow Queen, Light Blue. Six packets Sweet Peas, as follows: Emily Henderson, Primrose, Firefly, New Countess, Daybreak, Gray Friar.

\section{No. 3. A COMPLETE FLOWER GARDEN.}

Worth $\$ 1.35$; for $\$ 1.00$.

Ageratum, Alyssum, Giant Comet Aster, Candytuft, Calliopsis, Margaret Carnation Mixed, Columbine, Cosmos, California Poppy, Mixed Hollyhock, Larkspur, Marigold, Sweet Mignonette, Imperial Japanese Morning Glory, Tall Nasturtium, Trimardeau Mixed Pansy, Mixed Phlox, The Shirley Poppy, Eckford's Sweet Peas, Verbena.

\section{No. 4. THE VEGETABLE GARDEN.}

\section{Worth $\$ 1.00$; for 80 c.}

Beans, Beet, Cabbage, Carrot, Corn, Cucumber, Lettuce, Musk Melon, Water Melon, Onion, Parsnip, Peas, Pumpkin, Radish, Squash, Tomato, Turnip.

No. 5. BULBS.

Worth 1.05; for $75 \mathrm{c}$.

1 Double Dahlia, 1 Cactus Dahlia, 2 large Mixed Gladioli, 1 Cinnamon Vine, 1 Auratum, 1 Speciosum Rubrum, 3 Longiflorums.

No. 6. LILIES.

Worth 90c; for 30c.

6 Pure White Longiflorums.

Descriptions of Pansies on pages 53 and $54^{\circ}$ of Sweet Peas on 56 and 57 ; General List of Fower Seeds on pages 47 to 58 inclusire; of Bulbs on pages 55 and 56 .

Discnunts and premiums do not apply on these collections. 


\section{Spray Pumps}

Fertilizers $\hat{\theta}$
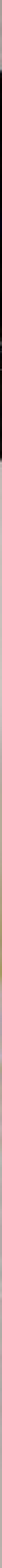